\title{
PROVA DE CARGA DINÂMICA EM PLACA
}

\author{
Luciene Santos de Moraes
}

Dissertação apresentada à Escola de Engenharia de São Carlos da Universidade de São Paulo, como parte dos requisitos para obtenção do título de Mestre em Geotecnia

ORIENTADOR: Prof. Dr. José Carlos Angelo Cintra 
Aos meus pais e a Moacir Leite

(in memoriam) 


\section{AGRADECIMENTOS}

Ao Prof. Dr. José Carlos Angelo Cintra pela valiosa orientação durante o desenvolvimento deste trabalho.

Aos colegas do departamento de Geotecnia pelo inestimável apoio, principalmente durante a execução das provas de carga estática.

À In Situ Geotecnia pelo apoio na realização das provas de carga dinâmica, especialmente ao Prof. Dr. Alessander Kormann e ao Eng. Luis Fernando Debas pelos inúmeros auxílios na compreensão dos procedimentos executivos e de análises do programa CAPWAP®.

Ao Prof. Dr. Nelson Aoki pelas importantes sugestões fornecidas no desenvolvimento desta pesquisa.

Aos professores e funcionários do Departamento de Geotecnia da USP/São Carlos pela cooperação.

Ao CNPa pela bolsa concedida. 


\section{RESUMO}

MORAES, L. M. Prova de Carga Dinâmica em Placa. São Carlos, 2005. 144 p. Dissertação (mestrado) - Escola de Engenharia de São Carlos, Universidade de São Paulo.

A prova de carga dinâmica é freqüentemente utilizada na determinação da capacidade de carga de fundações por estacas cravadas e há relatos de uso com sucesso deste ensaio em estacas escavadas e tubulões. Esta pesquisa envolveu a adaptação e execução da prova de carga dinâmica na placa de aço circular de diâmetro 0,80 m, com o objetivo de inferir a capacidade de carga do sistema placa-solo. Como a prova de carga dinâmica permite que seja feita a comprovação da carga durante a cravação, vislumbrase também a viabilização desse tipo de ensaio em solos porosos por meio da cravação da placa o necessário para atingir a capacidade de carga exigida em um projeto. Os ensaios foram realizados no campo experimental da USP/São Carlos, com solo superficial não saturado, poroso e colapsível, por isso foram feitas medidas dos valores de sucção matricial, já que esta exerce forte influência sobre a capacidade de carga.

Palavras-chave: prova de carga direta, prova de carga dinâmica, solo colapsível. 


\section{ABSTRACT}

MORAES, L. M. Dynamic Load Plate Test. São Carlos, 2005. 144 p. Dissertação (mestrado) - Escola de Engenharia de São Carlos, Universidade de São Paulo.

The dynamic load test is frequently used in the determination of driven piles foundation bearing capacity. It is also reported the successful use of the test in bored piles and caissons. This research included the adaptation and execution of the dynamic load test in circular steel plate, to verify the bearing capacity of footing foundations. Since the dynamic load tests allow the bearing capacity to be verified during the construction, it is also glimpsed the possibility of using this test in porous soils by penetrating the plate into the soil until the expected bearing capacity is achieved. The tests were held at the USP/São Carlos experimental foundation camp, which has superficial unsaturated, porous and colapsive soil, so matric suction's measurement were made, since it has strong influence on the bearing capacity.

Key words: Plate load test, dynamic load test, colapsive soil. 


\section{SUMÁRIO}

LISTA DE FIGURAS

LISTA DE TABELAS

1. INTRODUÇÃO 1

2. REVISÃO BIBLIOGRÁFICA 3

2.1 SUCÇÃO E COLAPSIBILIDADE___ 3

2.1.1 INFLUÊNCIA DA SUCÇÃO NA CAPACIDADE DE CARGA__ 4

2.1.2 SOLOS COLAPSÍVEIS___ 6

2.2 PROVA DE CARGA DINÂMICA__ 9

2.2.1 FÓRMULAS DINÂMICAS___ 11

2.2.2 EQUAÇÃO DA ONDA _ 12

2.2.3 MODELO DE SMITH _ 14

2.2.4 TÉCNICA DE INSTRUMENTAÇÃO _ 17

2.2.5 MÉTODO DE ANÁLISE CASE ___ 18

2.2.6 MÉTODO DE ANÁLISE CAPWAP®__ 20

2.2.7 PROVA DE CARGA DINÂMICA COM ENERGIA CRESCENTE___ 24

2.3 PROVA DE CARGA ESTÁTICA EM PLACA _ 25

2.3.1 TIPOS DE ENSAIO _ 26

2.3.2 INTERPRETAÇÃO DE PROVAS DE CARGA ESTÁTICA _ 29

2.4 COMPARAÇÃO ENTRE PROVA DE CARGA ESTÁTICA E DINÂMICA___ 34

3. CAMPO EXPERIMENTAL DE FUNDAÇÕES _ 36

4. MATERIAIS E MÉTODOS _ 42

4.1 PROVAS DE CARGA DINÂMICA__ 43

4.1.1 ADAPTAÇÃO DO ENSAIO__ 43

4.1.2 INSTRUMENTAÇÃO UTILIZADA _ 46

4.1.3 ANALISADOR - PILE DRIVING ANALYSER (PDA) _ 48

4.1.4 SISTEMA DE IMPACTO E AMORTECIMENTO _ _ 49 
4.1.5 ENSAIOS COM TERRENO INUNDADO 50

4.1.6 MEDIÇÃO DE NEGA _ _ 51

4.1.7 SEQÜÊNCIA DE REALIZAÇÃO DAS PROVAS DE CARGA DINÂMICA _ _ 52

4.2 PROVAS DE CARGA ESTÁTICA _ 54

4.2.1 EQUIPAMENTOS E MATERIAIS UTILIZADOS_ 56

4.2.2 SISTEMA DE REAÇÃO _ _ 59

4.3 MEDIDAS DE SUCÇÃO MATRICIAL__ 61

5. RESULTADOS_ 63

5.1 PROVAS DE CARGA DINÂMICA EM PLACA _ 63

5.1.1 MEDIDA DOS DESLOCAMENTOS__ 67

5.2 PROVAS DE CARGA ESTÁTICA EM PLACA__ 68

5.3 TENSIOMETRIA _ 71

6. ANÁLISE DOS RESULTADOS__ 72

6.1 ANÁLISES CAPWAP® 72

6.1.1 MATCH QUALITY 72

6.2 COMPARAÇÃO ENTRE OS MÉTODOS CASE E CAPWAP® _ 74

6.3 COMPARAÇÃO ENTRE PROVAS DE CARGA DINÂMICA E ESTÁTICA EM PLACA ___ 81

6.4 CAPACIDADE DE CARGA

6.4.1 INFLUÊNCIA DO EMBUTIMENTO__ 87

6.4.2 INFLUÊNCIA DA SUCÇÃO MATRICIAL _ 93

6.4.2.1 INFLUÊNCIA DA INUNDAÇÃO _ 95

6.5 ANÁLISE DAS PROVAS DE CARGA DINÂMICA ATRAVÉS DE ENERGIA___ 98

6.6 PARCELAS DE DESLOCAMENTO__ 103

7. CONCLUSÃO_ 108

REFERÊNCIAS BIBLIOGRÁFICAS___ 112

APÊNDICE A 118

APÊNDICE B 120 


\section{LISTA DE FIGURAS}

Figura 2.1 - Variação da capacidade de carga de sapatas corridas em função da sucção matricial (Fredlund \& Rahardjo, 1993)

Figura 2.2 - Curvas tensão x recalque de provas de carga sobre placa em solo não-saturado com diferentes sucções (Costa, 1999)

Figura 2.3 - Ocorrência de colapso em prova de carga realizada com inundação durante o ensaio (Cintra, 1998) 7

Figura 2.4 - Prova de carga em solo colapsível previamente inundado (Cintra, 1998) 8

Figura 2.5 - Conceito básico de recalque adicional devido ao colapso da estrutura do solo (Jennings \& Knight, 1975)

Figura 2.6 - Desenho esquemático do LFWD (Adam \& Adam, 2003) 11

Figura 2.7 - Solução da equação da onda 14

Figura 2.8 - Modelo de Smith (Smith, 1960) 16

Figura 2.9 - Esquema usual empregado em uma instrumentação dinâmica (Niyama et al., 1998)

Figura 2.10 - Método CAPWAP® - fluxograma (Alves, 2004) 22

Figura 2.11 - Ajuste da curva de força através de iteração (Hannigan, 1990) 23

Figura 2.12 - Reação com cargueira (Niyama et al., 1998) 26

Figura 2.13 - Resultados de provas de carga rápidas, lentas e mistas (Costa, 1999) 28

Figura 2.14 - Ruptura geral (Vesic, 1975) 29

Figura 2.15 - Ruptura por puncionamento (Vesic, 1975) 30

Figura 2.16 - Ruptura local (Vesic, 1975) 30

Figura 2.17 - Curva carga-recalque com ruptura nítida 31

Figura 2.18 - Ruptura física 32

Figura 2.19 - Resultados de provas de carga dinâmica e estática em estacas (Niyama \& Aoki, 1991)

Figura 2.20 - Resultados de provas de carga estática e simulações no CAPWAP® em duas estacas (Kormann et al., 2000)

Figura 3.1 - Seção esquemática da geologia de pequena profundidade em São Carlos (Bortolucci, 1983)

Figura 3.2 - Resultados de ensaios de SPT ao longo do perfil de solo (adaptado de Machado, 
1998) 37

Figura 3.3 - Curva característica de sucção (Machado, 1998) 39

Figura 3.4 - Curvas carga-recalque de três ensaios em tubulão a céu aberto, com solo previamente inundado (Benvenutti, 2001)

Figura 3.5 - Curvas carga-recalque de três ensaios em tubulão a céu aberto, com solo não inundado (Benvenutti, 2001)

Figura 4.1 - Disposição das cavas usadas nos ensaios em placa no Campo Experimental da USP/São Carlos 42

Figura 4.2 - Esquema da ligação tubo-placa 44

Figura 4.3 - Peça utilizada nos ensaios (tubo-placa) 45

Figura 4.4 - Instalação dos sensores 46

Figura 4.5 - Pile Driving Analyzer (PDA) 48

Figura 4.6 - Vista geral do ensaio 49

Figura 4.7 - Desenho esquemático do bate-estacas e da peça dentro da cava 50

Figura 4.8 - Distribuição da água 51

Figura 4.9 - Medição da nega 52

Figura 4.10 - Cava 2 (danificada) 53

Figura 4.11 - Utilização do gabarito de PVC 54

Figura 4.12 - Curvas tensão-recalque (Costa, 1999) 56

Figura 4.13 - Bomba hidráulica 57

Figura 4.14 - Montagem da prova de carga estática 57

Figura 4.15 - Indicador de deformações 58

Figura 4.16 - Esquema de montagem das provas de carga estática realizadas 60

Figura 4.17 - Esquemas do sistema de reação vistos em corte transversal 60

Figura 4.18 - Disposição dos tensiômetros na cava 5 62

Figura 5.1 - Curva resistência mobilizada x deslocamento (cava 1, terreno inundado) 63

Figura 5.2 - Curva resistência mobilizada x deslocamento (cava 3, terreno não inundado) 64 Figura 5.3 - Curva resistência mobilizada x deslocamento (cava 4, terreno não inundado) 64 Figura 5.4 - Curva resistência mobilizada x deslocamento (cava 6, terreno não inundado) 65 Figura 5.5 - Curva resistência mobilizada x deslocamento (cava 6, terreno inundado) 65 
Figura 5.6 - Curva resistência mobilizada x deslocamento (cava 7, terreno inundado) ___ 66

Figura 5.7 - Curva resistência mobilizada x deslocamento (cava 8, terreno inundado) 66

Figura 5.8 - Curva resistência mobilizada x deslocamento (cava 9, terreno não inundado) 67

Figura 5.9 - Medidas de nega (papel e lápis) x deslocamentos permanentes (PDA) 68

Figura 5.10 - Curva resistência x deslocamento (cava 4, terreno não inundado) 69

Figura 5.11 - Curva resistência x deslocamento (cava 7, terreno inundado) 69

Figura 5.12 - Curva resistência x deslocamento (cava 8, terreno inundado) 70

Figura 5.13 - Curva resistência x deslocamento (cava 9, terreno não inundado) 70

Figura 5.14 - Variação da sucção matricial e precipitação média diária ao longo do tempo 71

Figura 6.1 - Distribuição dos valores de match quality 72

Figura 6.2 - Curvas força resistente x recalque (cava 9, não inundada) dos métodos CASE e CAPWAP®

Figura 6.3 - Curvas força resistente x recalque (cava 4, não inundada) dos métodos CASE e CAPWAP®

Figura 6.4 - Curvas força resistente x recalque (cava 7, inundada) dos métodos CASE e CAPWAP® 77

Figura 6.5 - Curvas força resistente x recalque (cava 8, inundada) dos métodos CASE e CAPWAP®

Figura 6.6 - Curvas força resistente x recalque (cava 6, não inundada) dos métodos CASE e CAPWAP®

Figura 6.7 - Curvas força resistente x recalque (cava 6, inundada) dos métodos CASE e CAPWAP®

Figura 6.8 - Curvas força resistente x recalque (cava 1, inundada) dos métodos CASE e CAPWAP®

Figura 6.9 - Curvas força resistente x recalque (cava 3, não inundada) dos métodos CASE e CAPWAP®

Figura 6.10 - Gráficos das figuras 6.2 a 6.9 em ordem crescente de energia (linha vermelha $=$ CAPWAP $\AA$, linha preta $=$ CASE)

Figura 6.11 - Curvas tensão x recalque de três ensaios consecutivos: um dinâmico entre dois estáticos (cava 9, terreno não inundado)

Figura 6.12 - Curvas tensão x recalque de três ensaios consecutivos: um dinâmico entre dois estáticos (cava 4, terreno não inundado)

Figura 6.13 - Curvas tensão x recalque de três ensaios consecutivos: um dinâmico entre dois estáticos (cava 7, terreno inundado) 
Figura 6.14 - Curvas tensão x recalque de três ensaios consecutivos: um dinâmico entre dois estáticos (cava 8 , terreno inundado) 86

Figura 6.15 - Embutimento x capacidade de carga (os marcadores pretos representam ensaios em cavas não inundadas e os marcadores brancos, inundadas) 90

Figura 6.16 - Curvas tensão-recalque (provas de carga dinâmica, cavas 1 e 3) 91

Figura 6.17 - Embutimento x capacidade de carga (os marcadores pretos representam ensaios em cavas não inundadas e os marcadores brancos, inundadas) 93

Figura 6.18 - Sucção matricial e precipitação ao longo do tempo 94

Figura 6.19 - Curva característica de sucção matricial (Machado, 1998) 95

Figura 6.20 - Curvas tensão-recalque de duas provas de carga dinâmica (cava 6) 96

Figura 6.21 - curvas tensão-recalque das provas de carga dinâmica da cava 6, com recalques acumulados 97

Figura 6.22 - Energia fornecida pelo PDA x energia calculada (cava 1) 99

Figura 6.23 - Energia fornecida pelo PDA x energia calculada (cava 3) 99

Figura 6.24 - Energia fornecida pelo PDA x energia calculada (cava 4) 100

Figura 6.25 - Energia fornecida pelo PDA x energia calculada (cava 6) 100

Figura 6.26 - Energia fornecida pelo PDA x energia calculada (cava 6 - reensaio) 101

Figura 6.27 - Energia fornecida pelo PDA x energia calculada (cava 7) 101

Figura 6.28 - Energia fornecida pelo PDA x energia calculada (cava 8) 102

Figura 6.29 - Energia fornecida pelo PDA x energia calculada (cava 9) 102

Figura 6.30 - Evolução do repique e da nega na prova de carga dinâmica com energia crescente (cava 1)

Figura 6.31 - Evolução do repique e da nega na prova de carga dinâmica com energia crescente (cava 3) 104

Figura 6.32 - Evolução do repique e da nega na prova de carga dinâmica com energia crescente (cava 4)

Figura 6.33 - Evolução do repique e da nega na prova de carga dinâmica com energia crescente (cava 6)

Figura 6.34 - Evolução do repique e da nega na prova de carga dinâmica com energia crescente (cava 6r)

Figura 6.35 - Evolução do repique e da nega na prova de carga dinâmica com energia crescente (cava 7) 106

Figura 6.36 - Evolução do repique e da nega na prova de carga dinâmica com energia crescente (cava 8) 
Figura 6.37 - Evolução do repique e da nega na prova de carga dinâmica com energia crescente (cava 9)

Figura A.1 - Calibração da célula de carga

Figura B.1 - Curvas de força medida e calculada, e força e velocidade medidas, cava 1, golpe 1

Figura B.2 - Curvas de força medida e calculada, e força e velocidade medidas, cava 1, golpe 2

Figura B.3 - Curvas de força medida e calculada, e força e velocidade medidas, cava 1, golpe 3

Figura B.4 - Curvas de força medida e calculada, e força e velocidade medidas, cava 1 , golpe 4

Figura B.5 - Curvas de força medida e calculada, e força e velocidade medidas, cava 1, golpe 5

Figura B.6 - Curvas de força medida e calculada, e força e velocidade medidas, cava 3 , golpe 1

Figura B.7 - Curvas de força medida e calculada, e força e velocidade medidas, cava 3, golpe 2

Figura B.8 - Curvas de força medida e calculada, e força e velocidade medidas, cava 3 , golpe 3

Figura B.9 - Curvas de força medida e calculada, e força e velocidade medidas, cava 3 , golpe 4

Figura B.10 - Curvas de força medida e calculada, e força e velocidade medidas, cava 3 , golpe 5

Figura B.1 1 - Curvas de força medida e calculada, e força e velocidade medidas, cava 3, golpe 6

Figura B.12 - Curvas de força medida e calculada, e força e velocidade medidas, cava 3 , golpe 7

Figura B.13 - Curvas de força medida e calculada, e força e velocidade medidas, cava 4, golpe 1

Figura B.14 - Curvas de força medida e calculada, e força e velocidade medidas, cava 4 , golpe 2

Figura B.15 - Curvas de força medida e calculada, e força e velocidade medidas, cava 4 , golpe 3

Figura B.16 - Curvas de força medida e calculada, e força e velocidade medidas, cava 4 , golpe 4

Figura B.17 - Curvas de força medida e calculada, e força e velocidade medidas, cava 4 , golpe 5 
Figura B.18 - Curvas de força medida e calculada, e força e velocidade medidas, cava 4 , golpe 6

Figura B.19 - Curvas de força medida e calculada, e força e velocidade medidas, cava 4 , golpe 7

Figura B.20 - Curvas de força medida e calculada, e força e velocidade medidas, cava 4 , golpe 8

Figura B.21 - Curvas de força medida e calculada, e força e velocidade medidas, cava 4 , golpe 9

Figura B.22 - Curvas de força medida e calculada, e força e velocidade medidas, cava 4 , golpe 10

Figura B.23 - Curvas de força medida e calculada, e força e velocidade medidas, cava 4 , golpe 11

Figura B.24 - Curvas de força medida e calculada, e força e velocidade medidas, cava 4 , golpe 12

Figura B.25 - Curvas de força medida e calculada, e força e velocidade medidas, cava 4 , golpe 13

Figura B.26 - Curvas de força medida e calculada, e força e velocidade medidas, cava 4 , golpe 14

Figura B.27 - Curvas de força medida e calculada, e força e velocidade medidas, cava 6 , golpe 1

Figura B.28 - Curvas de força medida e calculada, e força e velocidade medidas, cava 6 , golpe 2

Figura B.29 - Curvas de força medida e calculada, e força e velocidade medidas, cava 6 , golpe 3

Figura B.30 - Curvas de força medida e calculada, e força e velocidade medidas, cava 6 , golpe 4

Figura B.31 - Curvas de força medida e calculada, e força e velocidade medidas, cava 6 , golpe 5

Figura B.32 - Curvas de força medida e calculada, e força e velocidade medidas, cava 6 , golpe 6

Figura B.33 - Curvas de força medida e calculada, e força e velocidade medidas, cava 6, golpe 7

Figura B.34 - Curvas de força medida e calculada, e força e velocidade medidas, cava 6 , golpe 8

Figura B.35 - Curvas de força medida e calculada, e força e velocidade medidas, cava 6 , golpe 9

Figura B.36 - Curvas de força medida e calculada, e força e velocidade medidas, cava $6 r$, golpe 1 
Figura B.37 - Curvas de força medida e calculada, e força e velocidade medidas, cava 6 r, golpe 2

Figura B.38 - Curvas de força medida e calculada, e força e velocidade medidas, cava br, golpe 3

Figura B.39 - Curvas de força medida e calculada, e força e velocidade medidas, cava 6 r, golpe 4

Figura B.40 - Curvas de força medida e calculada, e força e velocidade medidas, cava 6 r, golpe 5

Figura B.41 - Curvas de força medida e calculada, e força e velocidade medidas, cava 6 r, golpe 6

Figura B.42 - Curvas de força medida e calculada, e força e velocidade medidas, cava 7 , golpe 1

Figura B.43 - Curvas de força medida e calculada, e força e velocidade medidas, cava 7 , golpe 2

Figura B.44 - Curvas de força medida e calculada, e força e velocidade medidas, cava 7 , golpe 3

Figura B.45 - Curvas de força medida e calculada, e força e velocidade medidas, cava 7 , golpe 4

Figura B.46 - Curvas de força medida e calculada, e força e velocidade medidas, cava 7 , golpe 5

Figura B.47 - Curvas de força medida e calculada, e força e velocidade medidas, cava 7 , golpe 6

Figura B.48 - Curvas de força medida e calculada, e força e velocidade medidas, cava 7 , golpe 7

Figura B.49 - Curvas de força medida e calculada, e força e velocidade medidas, cava 7 , golpe 8

Figura B.50 - Curvas de força medida e calculada, e força e velocidade medidas, cava 7 , golpe 9

Figura B.51 - Curvas de força medida e calculada, e força e velocidade medidas, cava 7 , golpe 10

Figura B.52 - Curvas de força medida e calculada, e força e velocidade medidas, cava 8, golpe 1

Figura B.53 - Curvas de força medida e calculada, e força e velocidade medidas, cava 8 , golpe 2

Figura B.54 - Curvas de força medida e calculada, e força e velocidade medidas, cava 8 , golpe 3

Figura B.55 - Curvas de força medida e calculada, e força e velocidade medidas, cava 8 , golpe 4 
Figura B.56 - Curvas de força medida e calculada, e força e velocidade medidas, cava 8, golpe 5

Figura B.57 - Curvas de força medida e calculada, e força e velocidade medidas, cava 8, golpe 6

Figura B.58 - Curvas de força medida e calculada, e força e velocidade medidas, cava 8, golpe 7

Figura B.59 - Curvas de força medida e calculada, e força e velocidade medidas, cava 8, golpe 8

Figura B.60 - Curvas de força medida e calculada, e força e velocidade medidas, cava 9 , golpe 1

Figura B.61 - Curvas de força medida e calculada, e força e velocidade medidas, cava 9, golpe 2

Figura B.62 - Curvas de força medida e calculada, e força e velocidade medidas, cava 9 , golpe 3

Figura B.63 - Curvas de força medida e calculada, e força e velocidade medidas, cava 9 , golpe 4

Figura B.64 - Curvas de força medida e calculada, e força e velocidade medidas, cava 9, golpe 5

Figura B.65 - Curvas de força medida e calculada, e força e velocidade medidas, cava 9 , golpe 6

Figura B.66 - Curvas de força medida e calculada, e força e velocidade medidas, cava 9 , golpe 7

Figura B.67 - Curvas de força medida e calculada, e força e velocidade medidas, cava 9 , golpe 8 


\section{LISTA DE TABELAS}

Tabela 2.1 - Constante de amortecimento de CASE em função do tipo de solo, valores indicativos (Rausche et al., 1985)

Tabela 4.1 - Alturas de queda das provas de carga dinâmica 53

Tabela 6.1 - Energia máxima aplicada ao sistema e desvio padrão médio entre os métodos CASE e CAPWAP® para cada cava

Tabela 6.2 - Valores de capacidade de carga e sucção matricial (cava 9, terreno não inundado)

Tabela 6.3 - Valores de capacidade de carga e sucção matricial (cava 4, terreno não inundado)

Tabela 6.4 - Valores de capacidade de carga e sucção matricial (cava 7, terreno inundado)

Tabela 6.5 - Valores de capacidade de carga e sucção matricial (cava 8, terreno inundado)

Tabela 6.7 - Capacidade de carga considerando a placa sem embutimento, com embutimento de 10\%, 20\% e 30\% do diâmetro, e sucção matricial no momento dos ensaios

Tabela 6.8 - Taxas de aumento da capacidade de carga em função da cravação para as cavas 1 e 3

Tabela 6.9 - Valores de capacidade de carga em função do embutimento (dois ensaios, cava 6) 


\section{INTRODUCÃO}

O dimensionamento geométrico de fundações diretas é feito a partir de uma tensão admissível $\sigma_{a}$ previamente estimada. De acordo com a NBR 6122/96 - Projeto e Execução de Fundações, a tensão admissível pode ser estimada segundo métodos teóricos, semiempíricos, provas de carga sobre placa e empíricos. As provas de carga sobre placa raramente são executadas, e além dos métodos teóricos, a estimativa de $\sigma_{a}$, na maioria dos casos, se baseia em sondagens SPT, normalmente a única investigação geotécnica disponível.

Uma alternativa seria a realização de provas de carga dinâmica, que são comumente usadas no caso de fundações por estacas cravadas. A monitoração durante a cravação é uma ferramenta importante e tem sido largamente empregada. Este sistema proporciona resposta rápida na determinação da resistência mobilizada, durante a instalação da estaca. Já há alguns anos, tem-se estendido este monitoramento a estacas moldadas in loco, como forma de se ter um processo de avaliação da resistência estática mobilizada mais rápido e menos oneroso que provas de carga estática. Pesquisas já comprovaram a aplicabilidade da técnica também em tubulões.

Esta pesquisa envolveu a adaptação, a realização e a interpretação da prova de carga dinâmica em placa de aço circular rígida de diâmetro 0,80 m, com o intuito de averiguar a possibilidade do uso deste ensaio, aliado aos métodos de análise baseados na propagação de tensão em barras (equação da onda), com o objetivo de inferir a capacidade de carga do sistema placa-solo.

São comparados os resultados obtidos em provas de carga dinâmica e estática, realizadas no Campo Experimental de Fundações da USP/São Carlos, cujo perfil de solo típico apresenta uma camada superficial pouco compacta, muito porosa e colapsível, devido à ação de intemperismo sob condições típicas de região tropical. Por esta razão, os 
ensaios foram realizados em cavas inundadas e não inundadas, monitorados por tensiômetros, para obtenção da sucção matricial. Este monitoramento é de grande importância, pois a sucção matricial exerce forte influência na capacidade de carga (Costa, 1999).

Nesse solo poroso, as curvas tensão-recalque obtidas em vários ensaios em placa, sapatas e tubulões mostram que os recalques são plásticos e a tensão é "sempre" crescente com o aumento do recalque, não apresentando uma ruptura nítida. A cravação da placa representa então uma majoração importante da capacidade de carga, por conferir um aumento de rigidez do solo sob ela.

Como a realização de provas de carga dinâmica possibilita a verificação da capacidade de carga concomitantemente à cravação, é possível vislumbrar a viabilização de fundações rasas nesse tipo de solo, por meio da cravação da placa o necessário para atingir a capacidade de carga exigida em um projeto. 


\section{REVISÃO BIBLIOGRÁFICA}

Neste capítulo serão abordados três assuntos importantes para o entendimento da pesquisa realizada: sucção matricial e colapsibilidade em solos não saturados, prova de carga dinâmica e prova de carga estática em placa.

\subsection{SUCÇÃO E COLAPSIBILIDADE}

De acordo com Gusmão Filho (1994) a maioria dos terrenos apresenta uma zona vadosa, que é a porção de solo acima do nível d'água. Na prática de engenharia, os solos não saturados estão presentes com muita freqüência nos terrenos sob os quais se projetam e executam fundações. Solos não saturados reagem diversamente a mudanças na pressão total e na sucção da água. O entendimento deste mecanismo permite a elaboração de projetos de fundação em solos não saturados mais racionais e mais econômicos.

Fredlund \& Rahardjo (1993) também afirmam que existem muitas situações em que o nível freático está bem abaixo da superfície e não é racional desenvolver um projeto baseado em um perfil saturado. Neste caso, medidas in situ da sucção abaixo das fundações de estruturas existentes na vizinhança podem ser muito úteis no desenvolvimento de projetos mais econômicos. 


\subsubsection{INFLUÊNCIA DA SUCÇÃO NA CAPACIDADE DE CARGA}

Em solos não saturados, um fator importante que deve ser considerado na análise da capacidade de carga é a sucção matricial. O papel relevante da sucção foi mostrado por Fredlund \& Rahardjo (1993), que quantificaram o aumento da capacidade de carga de fundações por sapatas corridas, de 0,5 e $1 \mathrm{~m}$ de largura assentes a 0,5 m de profundidade, com a sucção matricial (Figura 2.1), por meio da equação de Terzaghi (1943).

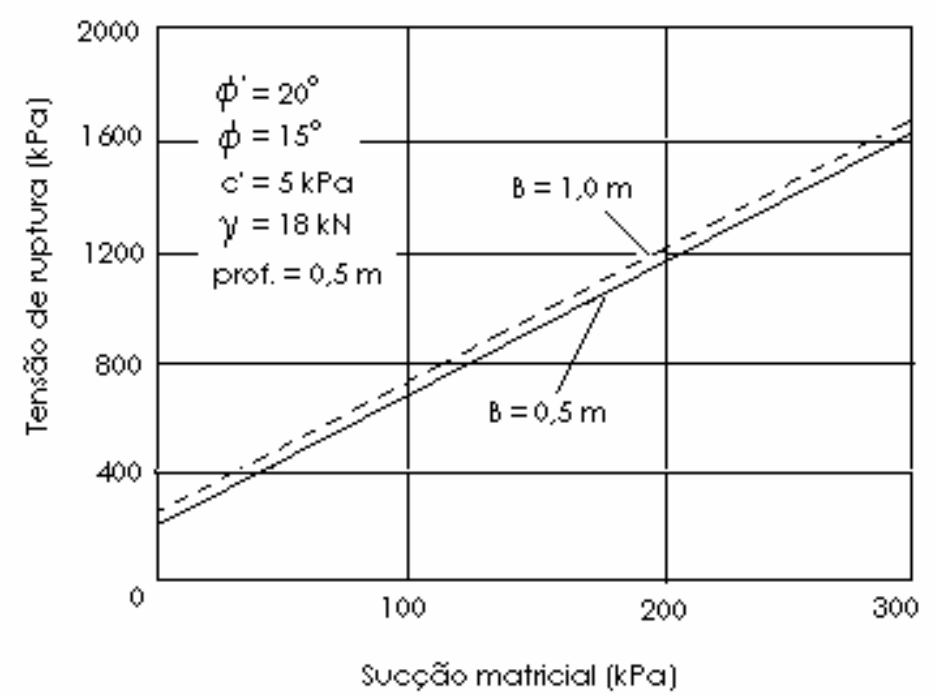

Figura 2.1 - Variação da capacidade de carga de sapatas corridas em função da sucção matricial (Fredlund \& Rahardjo, 1993)

Costa (1999) comprovou experimentalmente que a sucção matricial possui grande influência na capacidade de carga de fundações diretas. Por meio de provas de carga em placa, a 1,5 $\mathrm{m}$ de profundidade, realizadas no campo experimental de fundações da EESC/USP, o autor constatou que um pequeno aumento na sucção causa um substancial crescimento da capacidade de carga, como pode ser observado na Figura 2.2. 


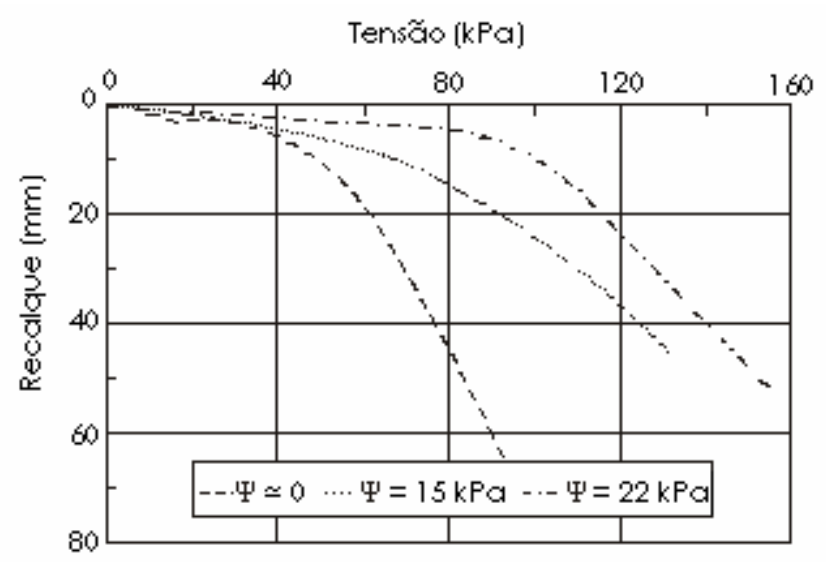

Figura 2.2 - Curvas tensão x recalque de provas de carga sobre placa em solo não-saturado com diferentes sucções (Costa, 1999)

A característica geral de um solo não saturado é que a sucção (poropressão negativa) varia com a mudança de umidade, o que influencia o desempenho das fundações. Mudanças de sucção podem ser induzidas pela infiltração de água de chuva no solo, através do mecanismo de avanço da frente de umedecimento, a partir da superfície do terreno. Também são freqüentes as mudanças de umidade provocadas pela atividade antrópica, que se refletem na sucção do solo não saturado. É o caso de obras que desviam o fluxo de água subterrânea, elevam ou rebaixam a posição do nível piezométrico, provocam vazamento ou aquecimento do terreno.

De acordo com Fredlund \& Rahardjo (1993), o solo não saturado tem duas parcelas de coesão. A primeira componente é a coesão efetiva e a segunda é devida à sucção matricial. Fredlund \& Rahardjo (1993) afirmam que, com este conceito em mente, a teoria de capacidade de carga convencional é aplicável aos solos não saturados.

O aumento da sucção matricial contribui para dar resistência ao solo contra mudanças nas pressões aplicadas externamente pelos elementos de fundação. Isso porque o aumento de sucção resulta em aumento da coesão c', e pouco afeta o ângulo de atrito ф' (Fredlund \& Rahardjo, 1993). 
O aumento de resistência devido à sucção não continua indefinidamente. No caso de solo seco, a envoltória de ruptura coincide basicamente com a envoltória de ruptura saturada. O efeito da sucção sobre a resistência tem seu máximo em um grau de saturação intermediário (Gusmão Filho, 1994).

Segundo Campos et al. (1994), utiliza-se como rotina, no dimensionamento de contenções, a adoção de parâmetros obtidos ou estimados a partir de ensaios de cisalhamento realizados na condição de inundação dos corpos de prova. Tal postura leva freqüentemente à adoção de contenções de grande custo. Esses projetos têm sido questionados, pois na abertura de grandes cortes, mantidos sem contenção durante muito tempo, é pouco freqüente a ocorrência de problemas de instabilidade. Isto se deve ao fato que os taludes permanecem em condição de não saturação, tendo aumento de resistência devido à sucção.

\subsubsection{SOLOS COLAPSÍVEIS}

Segundo Cintra (1998), em certos tipos de solos não saturados, a inundação pode causar uma espécie de colapso da estrutura, caracterizado por um recalque suplementar, repentino e de grandes proporções. Este tipo de recalque é chamado colapso e o solo é classificado como colapsível.

O solo colapsível apresenta uma estrutura instável, porém com uma rigidez temporária mantida pela pressão de sucção e/ou cimentação. Para este solo entrar efetivamente em colapso é preciso que duas condições sejam satisfeitas: elevação do teor de umidade e atuação de um carregamento. Assim, se a carga atuante é suficientemente elevada, a adição de água ao solo colapsível causa redução na resistência, pois reduz ou dissipa a sucção e/ou enfraquece ou destrói a cimentação, podendo levar ao colapso do 
solo (Cintra, 1998).

Os solos colapsíveis apresentam um comportamento característico da curva tensãodeformação. Na Figura 2.3 observa-se ocorrência de colapso em uma prova de carga realizada com inundação do solo durante o ensaio. Há uma redução acentuada de volume após a inundação.

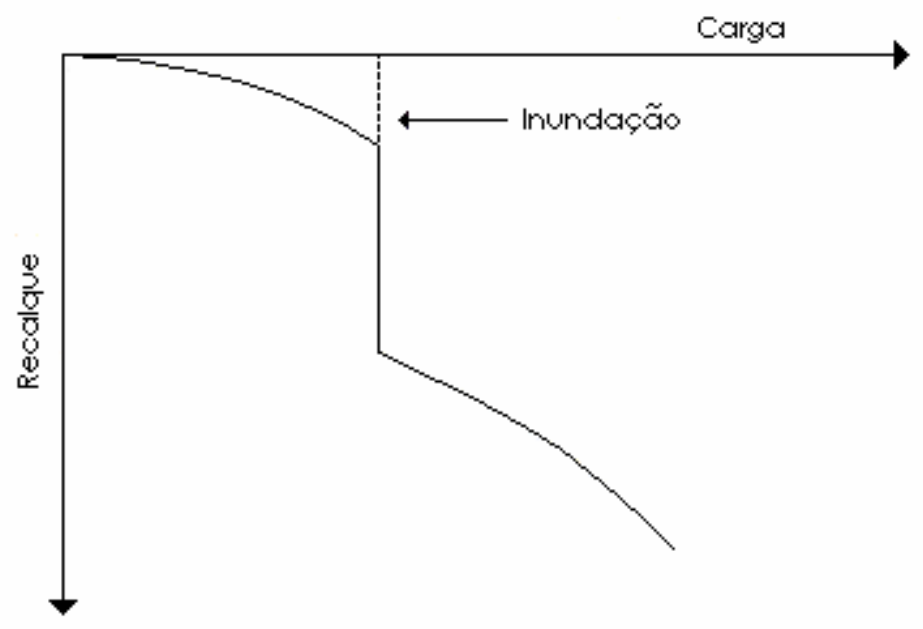

Figura 2.3 - Ocorrência de colapso em prova de carga realizada com inundação durante o ensaio (Cintra, 1998)

Em provas de carga com inundação prévia ao carregamento, o colapso não fica caracterizado por recalque repentino de grandes proporções, mas pelo aumento da deformação e pela redução da capacidade de carga (Figura 2.4). 


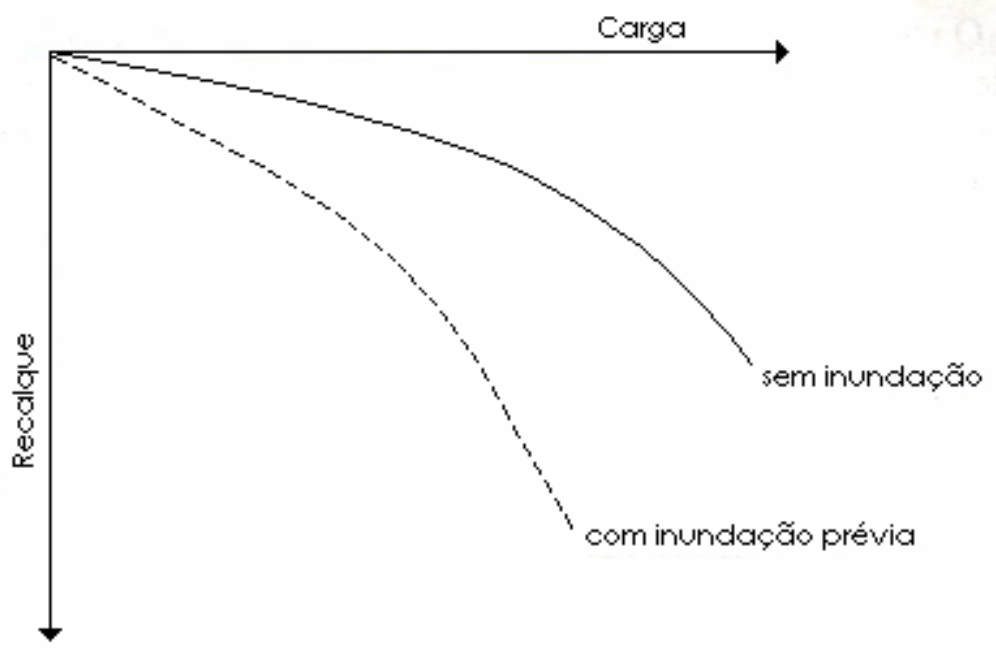

Figura 2.4 - Prova de carga em solo colapsível previamente inundado (Cintra, 1998)

As características dos solos colapsíveis explicam o fato de fundações rasas, instaladas neste tipo de solo, apresentarem comportamento satisfatório durante algum tempo e com a presença de água passem a gerar problemas, em geral decorrentes de recalques diferenciais significativos (Figura 2.5). O aparecimento de água pode ser devido ao rompimento de tubulações da rede de água e esgoto, avanço da frente de molhamento de águas pluviais, trincas em reservatórios subterrâneos, ascensão do lençol freático, etc. 

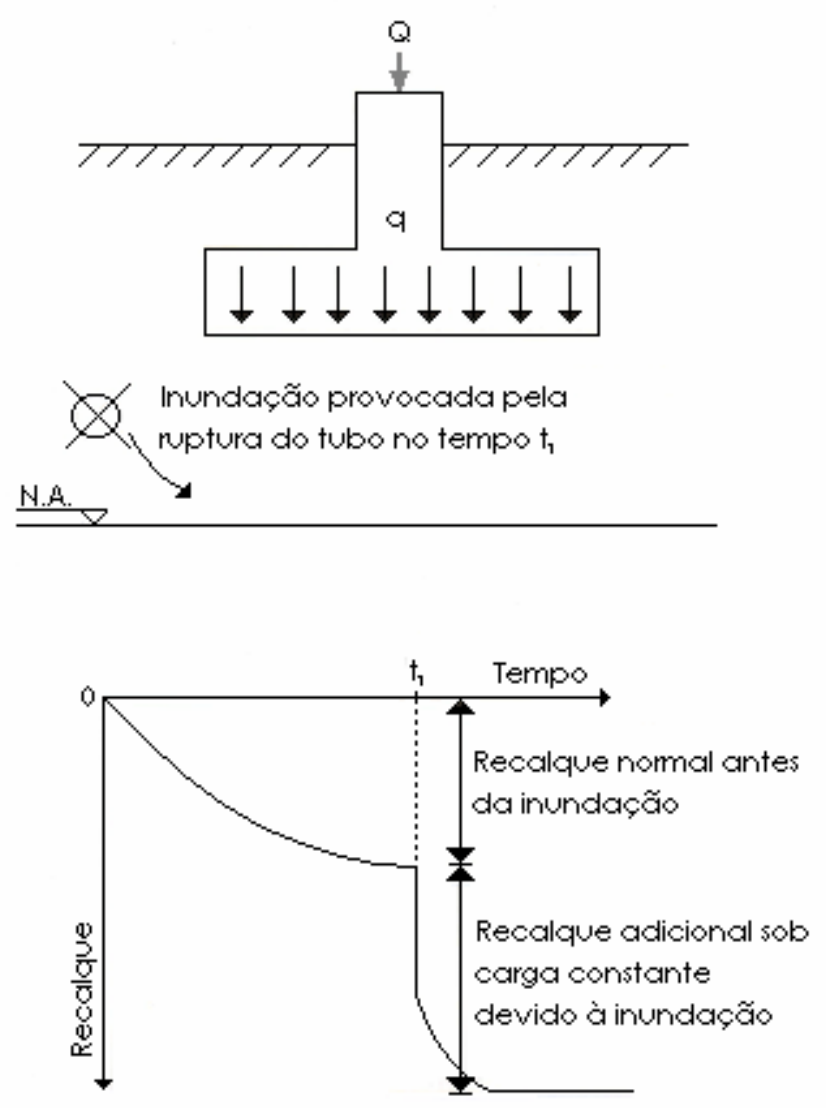

Figura 2.5 - Conceito básico de recalque adicional devido ao colapso da estrutura do solo (Jennings \& Knight, 1975)

\subsection{PROVA DE CARGA DINÂMICA}

A prova de carga dinâmica consiste da aplicação de um certo número de golpes por um martelo no topo de estacas, de modo a gerar ondas de deformação. É um ensaio em que se aplica um carregamento dinâmico axial no topo do elemento estrutural de fundação, com o objetivo de obter principalmente uma avaliação da sua capacidade de carga, com a utilização de instrumentação adequada e da aplicação da teoria da equação da onda.

De acordo com Navajas e Niyama (1996) a aplicação da técnica (prova de carga 
dinâmica) em substituição a três provas de carga estática, inicialmente previstas para uma dada obra, permitiv economia significativa de prazo, e maior ainda, de custos envolvidos. 0 sistema de reação numa prova de carga estática exigiria a execução de tirantes num local com lâmina d'água que variava de 4 a $8 \mathrm{~m}$, com dificuldades e custos inerentes.

A prova de carga dinâmica foi desenvolvida para estacas cravadas, porém há muitos relatos de uso com sucesso do ensaio em estacas escavadas (e.g. Niyama \& Aoki, 1991) e tubulões (e.g. Campelo, 2000).

A literatura mostra um relato do ensaio em placa. Adam \& Adam (2003) apresentam a modelagem mecânica da prova de carga dinâmica em placa com LFWD (Light Falling Weight Device - dispositivo leve de peso cadente). O dispositivo é utilizado para verificar o grau compactação de camadas de aterros e avaliar a capacidade de carga. O peso utilizado é de apenas 0,1 kN, e são efetuados três golpes, deixando o peso cair, guiado por uma haste, com altura de queda constante de $0,7 \mathrm{~m}$. As resistências mobilizadas são baixas e, por isso, não seria adequado para avaliação da capacidade de carga de fundações.

A placa do LFWD possui um acelerômetro instalado que fornece o deslocamento máximo no momento do golpe. A força é calculada através de modelos mecânicos e fórmulas dinâmicas, pois o dispositivo não possui transdutores de deformação. A Figura 2.6 apresenta um desenho esquemático do LFWD. 


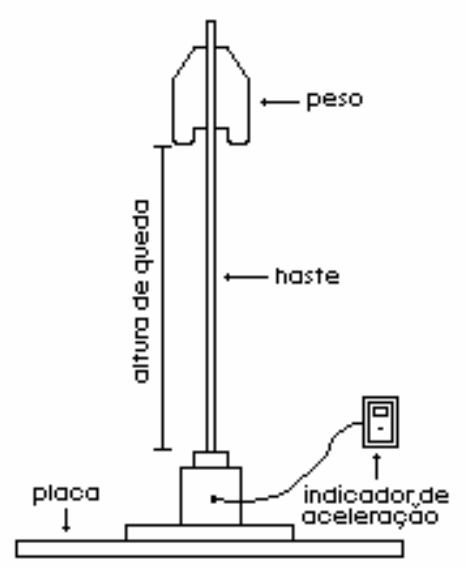

Figura 2.6 - Desenho esquemático do LFWD (Adam \& Adam, 2003)

\subsubsection{FÓRMULAS DINÂMICAS}

Segundo Aoki (1997), entre 1820 e 1950, a capacidade de carga estática de fundações por estacas, podia ser estimada a partir de uma série de impactos de energia constante, usando as fórmulas dinâmicas de cravação.

As fórmulas são baseadas no impacto Newtoniano, no princípio da conservação da energia e na hipótese de mobilização instantânea da capacidade de carga do solo ao longo da estaca. A definição da capacidade de carga estática nem sempre é claramente exposta pelo autor da fórmula e o dado básico a ser medido no impacto é a nega. As fórmulas ditas completas exigem ainda a medida das compressões elásticas temporárias do sistema de amortecimento, da estaca e do solo sob a estaca, para avaliação das perdas de energia (Aoki, 1997).

Atualmente, existem inúmeras fórmulas dinâmicas sem que haja uma concordância com relação às suas aplicações. Um dos principais problemas da utilização de fórmulas dinâmicas é a representação muito simplificada dos sistemas de cravação, de 
amortecimento e das perdas de energia.

De acordo com a NBR 6122/96 as provas de carga dinâmica devem ser executadas, em número igual ou superior a $3 \%$ do conjunto de estacas de mesmas características na obra (estacas pré-moldadas em concreto), respeitando-se o mínimo de três estacas instrumentadas com acelerômetros e transdutores de deformação. Os resultados dos métodos simplificados, que forem utilizados para interpretação dos dados de instrumentação de cada conjunto de estacas de mesmas características, devem ser aferidos por métodos numéricos baseados na equação da onda, em pelo menos uma recravação de estaca (prova de carga dinâmica), ou aferidos por uma prova de carga estática.

Aoki (1989) afirma que a interpretação dos sinais de nega e de repique elástico permite estimar com razoável precisão a carga mobilizada pelas estacas, no instante em que são registrados.

\subsubsection{EQUAÇÃO DA ONDA}

A equação da onda foi desenvolvida por Saint-Vénant por volta de 1866 para o estudo de um impacto sobre a extremidade de uma barra. Neste estudo, foi encontrada a equação diferencial que governa a propagação de ondas unidimensionais em uma barra elástica e também sua solução para algumas condições de contorno.

A equação da onda é uma equação diferencial de derivadas parciais de segunda ordem envolvendo as variáveis independentes: posição da seção $(x)$, onde se quer determinar o deslocamento $u(x, t)$, ao longo do tempo $(t)$. 
A equação da onda no caso particular de uma estaca sem resistência ao longo do fuste é:

$$
c^{2} \cdot \frac{\partial^{2} u}{\partial x^{2}}-\frac{\partial^{2} u}{\partial t^{2}}=0
$$

em que:

$c=$ velocidade da onda de tensão:

$$
c=\sqrt{\frac{E}{\rho}}
$$

$\mathrm{E}=$ módulo de deformabilidade do material da estaca;

$\rho$ = massa específica do material da estaca;

$\dagger=$ tempo;

A solução geral desta equação tem a forma:

$$
u(x, t)=g(x+c . t)+f(x-c . t)=W_{d} \downarrow+W_{u} \uparrow
$$

em que:

$u(x, t)=$ deslocamento da seção $z$ no instante $t$.

As duas funções componentes $g$ e f são denominadas de onda descendente $W_{d}$ (wave down) e onda ascendente $W_{u}$ (wave up), que se deslocam a uma velocidade $c$, sem mudar de forma, para baixo e para cima. Pode-se demonstrar que as ondas de força descendente e ascendente em dada seção da estaca podem ser determinadas conhecendo-se a força $\mathrm{F}$ e a velocidade $\vee$ nesta seção, por meio das expressões:

$$
\mathrm{W}_{\mathrm{d}}=\frac{(\mathrm{F}+\mathrm{Zv})}{2}
$$


$\mathrm{W}_{\mathrm{u}}=\frac{(\mathrm{F}-\mathrm{Zv})}{2}$

em que:

$Z$ = impedância da estaca $(Z=E A / c)$

$A=$ área da seção transversal da estaca

$F=$ força na seção

$v=$ velocidade na seção

Portanto a solução geral da equação da onda é representada graficamente por uma superfície de variação de deslocamento $u(x, t)$, velocidade $v(x, t)$, força $F(x, t)$, energia $E(x, t)$, resistência mobilizada $R_{\dagger}(x, t)$, etc.

A Figura 2.7 apresenta a superfície de deslocamentos $u(x, \dagger)$, da seção $x$ ao longo do tempo $t$, no intervalo entre $x=0$ (topo da estaca) e $x=\lambda$ (seção da base da estaca).

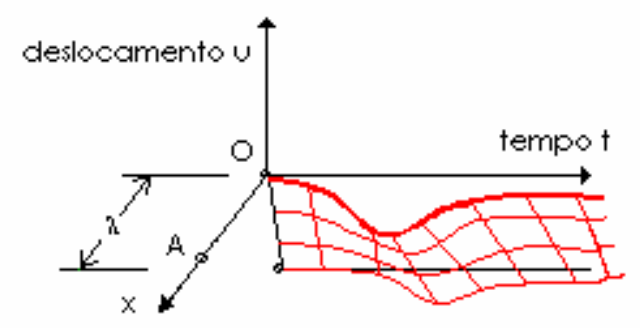

Figura 2.7 - Solução da equação da onda

\subsubsection{MODELO DE SMITH}

A compreensão do fenômeno da cravação de estacas sofreu avanços significativos a partir da solução da equação da onda por algoritmos apresentada por Smith (1960), que 
se tornou prática com os computadores, ocorrendo assim rápida difusão da prova de carga dinâmica em todo o mundo.

Smith (1960) propõe um modelo matemático para representar a cravação de estacas. Este modelo é baseado na equação da onda e utiliza integração numérica. A solução foi obtida pelo método das diferenças finitas, com o uso de computadores.

Aoki (1997) afirma que o modelo de Smith permite avaliar os deslocamentos, velocidades, acelerações e forças na seção da estaca, ao longo do tempo, substituindo com vantagens a fórmula dinâmica.

No modelo, o martelo, a estaca e outras partes envolvidas, como o cepo e o capacete, são representados através de uma série de pesos e molas como mostra a Figura 2.8. Os elementos rígidos e pesados são representados por pesos, sem elasticidade, como o capacete. A estaca, que é compressível, é representada por uma série de pesos e molas. O martelo também é considerado como elemento possuidor de peso e elasticidade. A resistência do solo é representada por uma combinação de molas elasto-plásticas ligadas em segmentos da estaca. 


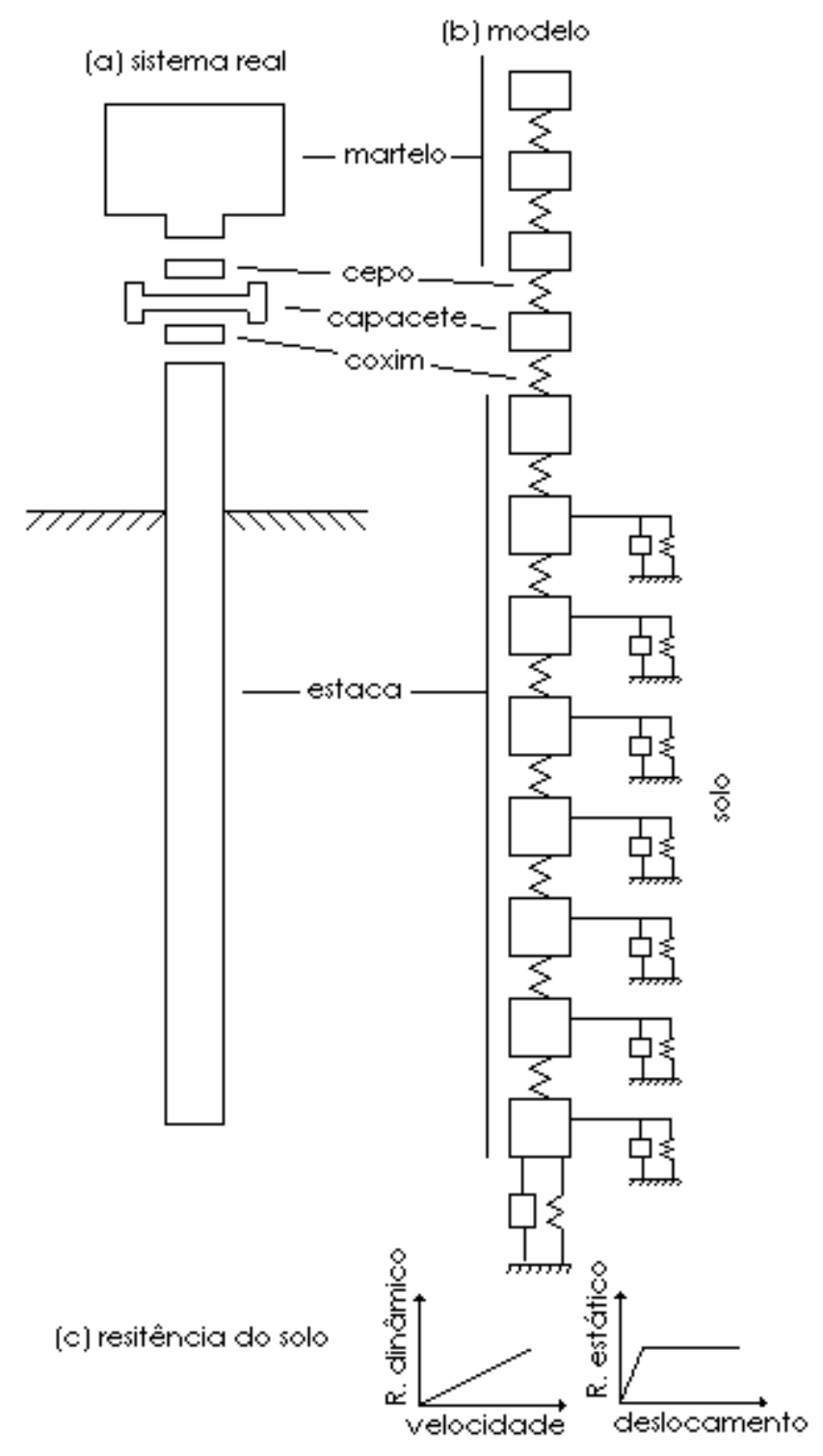

Figura 2.8 - Modelo de Smith (Smith, 1960)

O tempo durante o qual a ação ocorre (impacto do martelo sobre a estaca) é dividido em intervalos pequenos, como 1/4000 segundos. As ações de cada peso e cada mola são então calculadas separadamente em cada intervalo de tempo. Desta maneira, pode ser feita uma determinação matemática das tensões e da penetração da estaca ou deslocamento permanente por golpe, para qualquer tipo de solo ou grandeza de resistência do solo (Smith, 1960). 


\subsubsection{TÉCNICA DE INSTRUMENTAÇÃO}

Usualmente, na realização da instrumentação dinâmica, é utilizado o sistema PDA (Pile Driving Analyser), que é composto pelos seguintes equipamentos: dois acelerômetros, dois transdutores de deformação específica e um analisador de cravação. Os acelerômetros e transdutores de deformação são colocados em posições diametralmente opostas, próximas ao topo da estaca, para compensar os efeitos de momento fletor, e os sinais coletados por cada medidor, a cada golpe, são enviados através de cabos para o analisador - PDA (Figura 2.9).

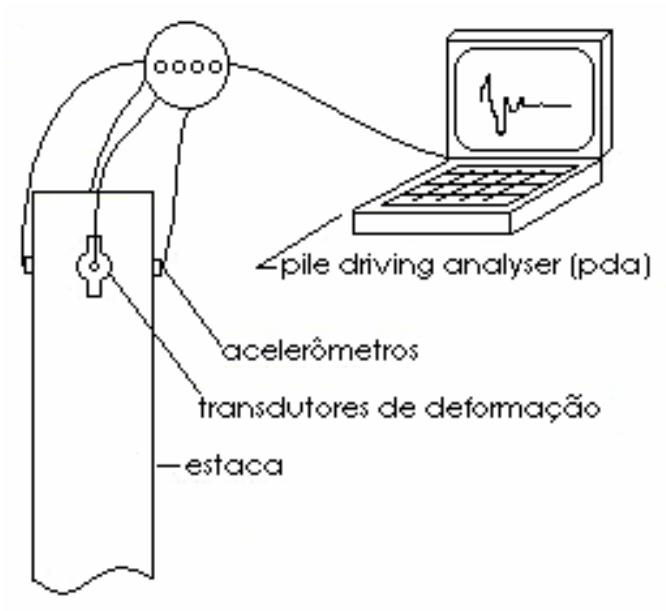

Figura 2.9 - Esquema usual empregado em uma instrumentação dinâmica (Niyama et al., 1998)

Os transdutores de deformação permitem obter registros de força através da lei de Hooke. Integrando a aceleração medida pelos acelerômetros, é possível obter a velocidade das partículas do elemento estrutural.

De acordo com Niyama et al. (1998), os sinais enviados pelos instrumentos são processados pelo PDA, que pode calcular vários parâmetros de interesse, sendo o principal a resistência à penetração da estaca no solo através do método simplificado CASE ou 
similar. Este sistema permite obter ainda:

- força máxima do impacto;

- energia máxima do golpe;

- energia aplicada ao sistema (EMX)

- eficiência do sistema de cravação;

- verificação de dano estrutural e sua posição;

- resistência máxima mobilizada (RMX);

- deslocamentos máximos (DMX);

- avaliação da distribuição da resistência.

A instrumentação dinâmica com o auxílio do PDA, quando associada a realizações de interpretações usando o programa CAPWAP®, permite quantificar separadamente as parcelas de tensão na ponta e fuste, permitindo uma análise dos métodos existentes de previsão da capacidade de carga (Andreo et al., 2000).

\subsubsection{MÉTODO DE ANÁlISE CASE}

O método CASE tem o nome da instituição na qual foi desenvolvido nas décadas de 60 e 70 (Case Western Research University, Ohio, EUA). Ele permite que se estime a resistência estática mobilizada em um golpe do martelo, através dos resultados de leituras de força e velocidade em uma seção instrumentada de uma estaca.

A estimativa da capacidade de carga do método CASE é dada pela soma do atrito lateral e resistência de ponta através da fórmula expedita: 
$R_{t}=\frac{\left[\left(F_{t 1}+F_{t 2}\right)+\left(\frac{E A}{c}\right) \cdot\left(v_{t 1}-v_{t 2}\right)\right]}{2}$

Em que:

$R_{\dagger}=$ resistência total dinâmica;

$F_{t 1}=$ força medida no instante $t 1 ;$

$\mathrm{F}_{+2}=$ força medida no instante $+2 ;$

$A$ = área da seção transversal do elemento estrutural de fundação;

$E$ = módulo de deformabilidade do material do elemento estrutural de fundação;

$c$ = velocidade da onda de tensão;

$v_{t l}=$ velocidade medida em $t_{1}$ (instante da passagem da onda incidente);

$v_{+2}=$ velocidade medida em $t_{2}$ (instante da chegada desta onda refletida na ponta).

A resistência à penetração, $R_{t}$, é considerada como sendo igual a soma de duas parcelas: uma estática $R_{s}$ e outra dinâmica Rd. Assim tem-se:

$$
R_{t}=R_{s}+R_{d}
$$

A resistência dinâmica é considerada proporcional à velocidade da ponta da estaca $\left(v_{p}\right)$, ou seja:

$$
R_{d}=\frac{J_{c} \cdot E A \cdot v_{p}}{c}
$$

Em que Jc é a constante de amortecimento CASE. A partir daí, pode-se deduzir que:

$$
v_{p}=\frac{2 \cdot v_{t 1}-c}{E A \cdot R_{t}}
$$

Fazendo-se as devidas substituições obtém-se: 


$$
R_{d}=J_{c} \cdot\left(2 F_{t 1}-R_{t}\right)
$$

A resistência estática, então, é dada pela diferença entre a resistência total e a dinâmica:

$$
R_{s}=R_{t}-J_{c} \cdot\left(2 F_{t 1}-R_{t}\right)
$$

A constante de amortecimento CASE, Jc, depende do tipo de solo, entre outros fatores, como o nível de energia aplicada no golpe. Rausche et al. (1985) sugerem valores indicativos de $\mathrm{J}_{c}$, que se encontram na tabela 2.1.

Tabela 2.1 - Constante de amortecimento de CASE em função do tipo de solo, valores indicativos (Rausche et al., 1985)

\begin{tabular}{|c|c|}
\hline$J_{\mathbf{c}}$ & Tipo de solo \\
\hline $0,10-0,15$ & areia pura \\
\hline $0,15-0,25$ & areia siltosa \\
\hline $0,25-0,40$ & silte \\
\hline $0,40-0,70$ & argila siltosa \\
$0,70-1,00$ & argila \\
\hline
\end{tabular}

\subsubsection{MÉTODO DE ANÁLISE CAPWAP®}

O método CAPWAP® (Case Pile Wave Analysis Program) foi desenvolvido paralelamente ao método CASE, na Case Western Research University (EUA), e permite uma análise mais elaborada dos sinais obtidos pela instrumentação.

Através do método CAPWAP®, o sistema estaca-solo é modelado por uma série de massas e molas com o objetivo de se obter a carga estática mobilizada durante o golpe do martelo. 
Segundo Niyama et al. (1998), o CAPWAP® é o programa mais utilizado para estimativa da capacidade de carga a partir de dados de medições de força e aceleração.

Na análise da cravação da estaca são consideradas três incógnitas: a força na estaca, a velocidade da estaca e a condição de contorno. Se duas das três são conhecidas, a outra pode ser determinada.

A condição de contorno inclui a resistência mobilizada, a distribuição de resistência, a deformação elástica máxima (quake) e a constante de amortecimento (damping).

No modelo CAPWAP® as forças de reação do solo são passivas e expressadas como uma função do movimento da estaca. A reação do solo é representada por componentes elastoplásticos e viscolineares. Assim, o modelo do solo possui, para cada ponto, três incógnitas: resistência estática mobilizada, quake e damping. A análise é iterativa, atribuindo-se valores para os parâmetros do solo. A mesma é prosseguida até a obtenção da concordância suficiente entre as curvas de força calculada e medida e, nessa situação, os correspondentes parâmetros do modelo são considerados representativos.

Entrando com os dados de velocidade da estaca e as condições de contorno assumidas, o programa calcula a curva que representa a força no topo da estaca. Essa força calculada é comparada com a força medida no ensaio obtida pelo PDA. Em um processo iterativo no computador, modifica-se o modelo do solo até que haja concordância (best match) entre as curvas de força medida e calculada. O processo computacional pode ser resumido no fluxograma da Figura 2.10. 


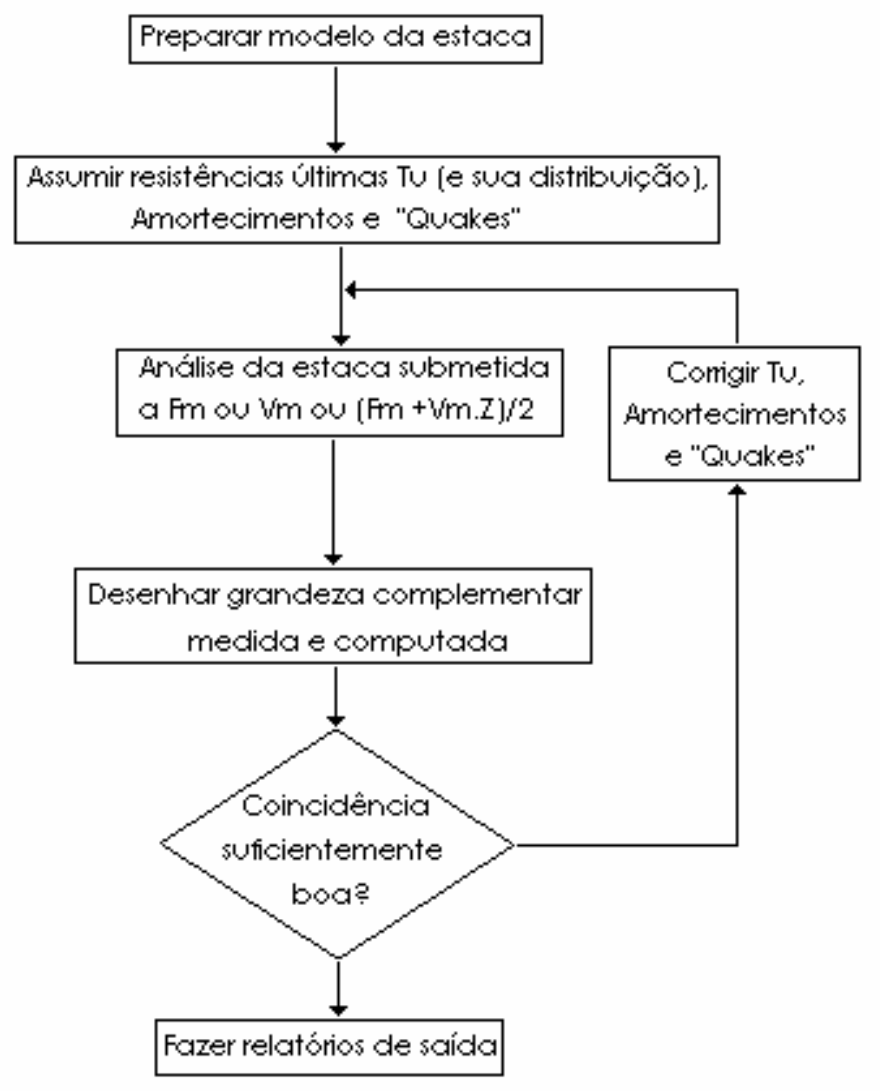

Figura 2.10 - Método CAPWAP® - fluxograma (Alves, 2004)

O processo de ajuste das curvas medidas e calculadas é controlado por diversos fatores como a distribuição da resistência e a resistência última mobilizada. Durante o processo de iteração o programa avalia a qualidade do ajuste (concordância entre as curvas) pelas diferenças relativas às curvas medida e calculada. As curvas são divididas em quatro regiões e, para cada uma, é atribuído um número, através da média geométrica, que representa a concordância das curvas. Estes números são somados e tem-se o match quality daquelas curvas. Quanto melhor for o ajuste, menor o valor do match quality. A Figura 2.11 mostra um processo de iteração feito em cinco tentativas. Nas primeiras tentativas foi modificada a distribuição da resistência na estaca ensaiada (fuste e ponta). Nas últimas tentativas foram modificados o modelo do solo sob a ponta e os parâmetros de descarregamento (Hannigan, 1990). 

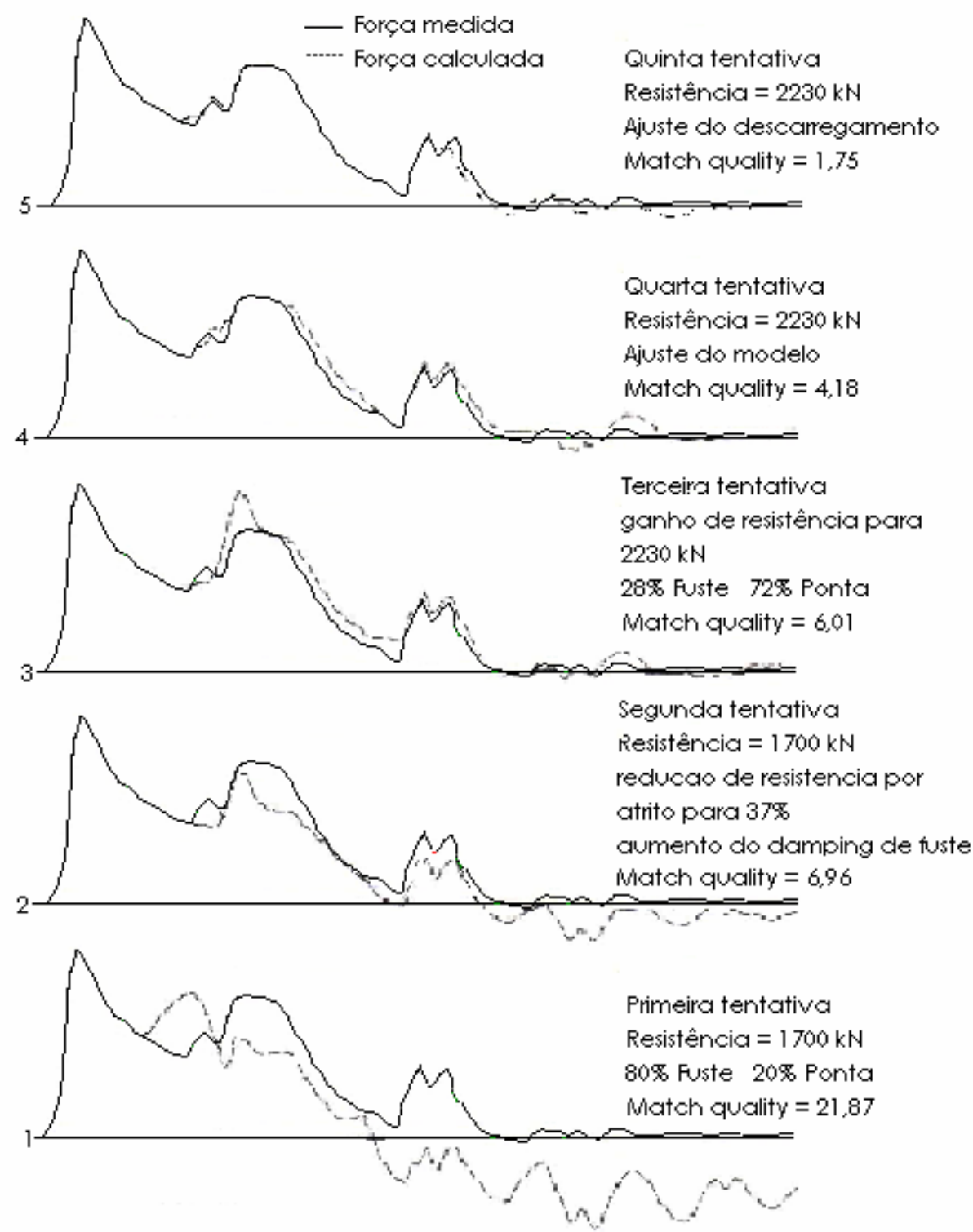

Figura 2.11 - Ajuste da curva de força através de iteração (Hannigan, 1990)

Uma vez atingido o melhor ajuste, o programa imprime o modelo de solo adotado, com os valores de resistência mobilizada, distribuição de resistência ao longo da profundidade, quake e damping.

O programa CAPWAP® também simula a prova de carga estática, usando o modelo da estaca, a distribuição da resistência e o quake. É simulada a aplicação de incrementos de carga no topo da estaca e calculada a penetração do elemento associada a valores 
estáticos de resistência. Assim, a curva carga-deslocamento do topo da estaca é determinada.

Com o valor da capacidade de carga estática, obtido a partir da análise CAPWAP®, pode ser feita a aferição de $J_{c}$ (constante de amortecimento CASE), utilizada no modelo do método simplificado CASE.

\subsubsection{PROVA DE CARGA DINÂMICA COM ENERGIA CRESCENTE}

Aoki (1991) comenta que a caracterização da resistência última implica a ocorrência de grandes deslocamentos. Por isso, alguns milímetros de penetração da estaca no solo, quando se aplica uma carga, não são suficientes para definir a capacidade de carga da fundação. Assim, a resistência inferida pela nega, pelo repique ou pela instrumentação dinâmica, corresponde à carga mobilizada pelo golpe do martelo e não à capacidade de carga na ruptura.

Aoki (1991) afirma que a pretensão de se determinar a capacidade de carga a partir de um golpe do martelo é comparável à tentativa de se determinar a capacidade de carga a partir de um único ponto da curva carga-recalque de uma prova de carga estática.

Aoki (1989) propõe uma prova de carga dinâmica com aplicação de impactos crescentes de energia possibilitando o traçado de uma curva carga estática mobilizada $\mathrm{x}$ deslocamento dinâmico semelhante à curva carga-recalque. As energias crescentes neste ensaio são obtidas pelo aumento das alturas de queda do martelo. 
Segundo Aoki (1997), na prova de carga dinâmica de energia crescente utilizando o sistema PDA, aplicam-se vários impactos de energia cinética (T) crescente, que mobilizam resistências (R) e resultam em deslocamentos (D). Para cada golpe são utilizados os mesmos modelos e interpretações do ensaio com energia constante. A partir dos resultados é possível analisar a evolução do comportamento do sistema estaca-solo sob a ação de energia cinética crescente.

O objetivo da prova de carga dinâmica de energia crescente é determinar a curva carga mobilizada $x$ deslocamento referente a uma série de golpes do martelo. A determinação da capacidade de carga através da curva é feita utilizando-se os mesmos procedimentos das provas de carga estática.

\subsection{PROVA DE CARGA ESTÁtICA EM PLACA}

A prova de carga em placa é um ensaio de campo, realizado na superfície ou em profundidade, cujo objetivo é a verificação do comportamento do sistema formado pela placa e o solo, sob um determinado carregamento, para obter informações acerca da resistência e da deformabilidade.

Há diversos tipos de montagem de provas de carga. Um sistema de reação adequado à direção, ao sentido e à intensidade das cargas de ensaio é necessário para permitir o apoio do macaco hidráulico ao aplicar o carregamento. Tradicionalmente, na prova de carga sobre placa, é usada uma cargueira, que pode um caixão de areia ou brita (Figura 2.12). Outra opção é usar a viga de reação fixada na extremidade de ancoragens solidarizadas ao terreno, ou no topo de estacas de reação, à semelhança das provas de carga estática em estacas. 


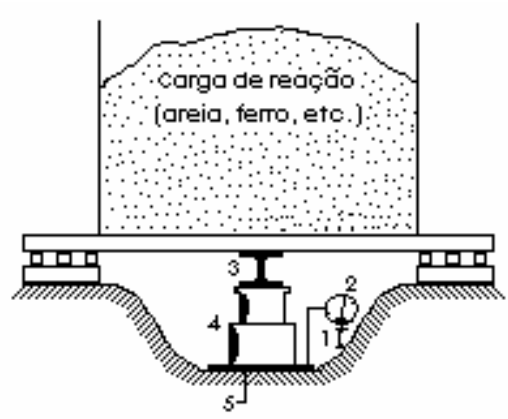

1 - VIg de referênci

2 - Defleotômetro

3 - viga de reggio

4 - Magoco hidráulio:

5 - Plas

Figura 2.12 - Reação com cargueira (Niyama et al., 1998)

\subsubsection{TIPOS DE ENSAIO}

\section{Ensaio lento - SML (Slow Maintained Load Test)}

O ensaio lento (SML) é descrito na NBR 6489/84 - Provas de Carga Direta Sobre Terreno de Fundação. No ensaio, uma placa de aço com 0,80 m de diâmetro é carregada em estágios por um macaco hidráulico reagindo contra uma viga de reação sustentada por cargueira, tirantes ou estacas de reação. De acordo com a norma, a tensão aplicada em cada estágio não deve ser superior a $20 \%$ da tensão admissível provável do solo e devese passar de um estágio para outro quando: "... a diferença entre duas leituras de recalques realizadas nos tempos $\dagger$ e $t / 2$ não ultrapassarem $5 \%$ do deslocamento total ocorrido no correspondente estágio de carregamento".

O ensaio deve atingir no mínimo recalque de $25 \mathrm{~mm}$ ou o dobro da tensão admissível provável do solo, sendo que a tensão máxima deve ser mantida por ao menos 12 horas, caso não ocorra ruptura nítida. As leituras dos recalques em cada estágio devem ser feitas 
imediatamente após a aplicação da carga e em seguida em intervalos dobrados de tempo.

O descarregamento deve ser realizado em quatro estágios, registrando-se os recalques correspondentes. Cada estágio de descarregamento deve ser mantido até a estabilização.

\section{Ensaio rápido - QML (Quick Maintained Load Test)}

No Brasil, não há uma norma específica para a realização do ensaio rápido em placa, por isso, costuma-se adotar as recomendações da NBR 12131/91 - "Estacas - Prova de Carga Estática", na qual consta que a carga aplicada em cada estágio não deve ser superior a $10 \%$ da carga admissível prevista e deverá permanecer por cinco minutos, fazendo-se leitura dos deslocamentos ao menos no início e no término de cada estágio de carga.

No caso de não ocorrer ruptura nítida ou deslocamento excessivo do solo, o ensaio deve ser conduzido até o dobro da carga admissível prevista. O descarregamento deve ser feito em quatro estágios, com leituras dos deslocamentos. A leitura final deve ser realizada dez minutos após o descarregamento total.

Fellenius (1975) recomenda que cada estágio de carga seja mantido por quinze minutos com leituras de deslocamentos a cada três minutos. Considerando um ensaio com 20 estágios de carregamento e quatro de descarregamento, o tempo total na proposição de Fellenius é de seis horas, o que viabiliza a realização do ensaio dentro de um dia. Com estágios de cinco minutos, como a norma sugere, esse tempo total fica reduzido a duas horas, que representa pouco quando comparado ao tempo de montagem e desmontagem. 
O ensaio QML possui ampla aceitação, pois são diminuídos os custos envolvidos e o tempo de ensaio. Segundo Fellenius (1980), o ensaio de carregamento rápido leva outra vantagem sobre o lento, que é a melhor definição da curva carga-recalque, pois prevê o dobro de pontos.

\section{Ensaio misto - MML (Mixed Maintained Load Test)}

No ensaio misto (MML), a primeira parte do ensaio é realizada tal como no ensaio lento e a segunda como no ensaio rápido.

Costa (1999) comparou ensaios rápidos, lentos e mistos em placa, realizados a 1,5 m de profundidade e observou que as curvas das provas de carga mistas apresentam comportamento semelhante ao das curvas dos ensaios lentos e rápidos (Figura 2.13), podendo concluir que a aplicação do ensaio misto é viável no solo estudado. Na realização dos ensaios mistos, adotou-se como critério para mudança do tipo de ensaio o valor da tensão admissível provável, desde que fosse atingido pelo menos $10 \mathrm{~mm}$ de recalque. Os incrementos de carga aplicados na fase rápida tiveram valor correspondente à metade do valor dos incrementos da fase lenta.

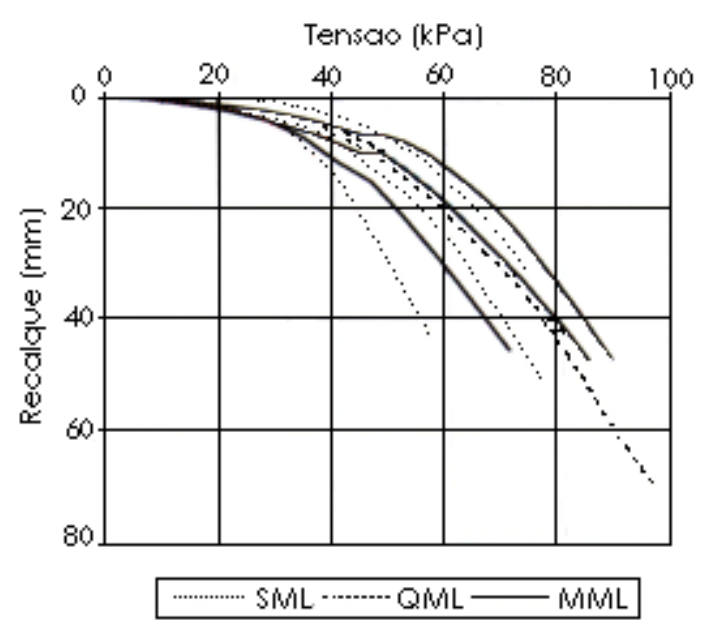

Figura 2.13 - Resultados de provas de carga rápidas, lentas e mistas (Costa, 1999) 


\title{
2.3.2 INTERPRETAÇÃO DE PROVAS DE CARGA ESTÁTICA
}

\begin{abstract}
Modos de ruptura
Terzaghi (1943) distingue dois mecanismos de ruptura em fundações: a ruptura geral, para solos compactos e rijos, e a ruptura local, para solos mais compressíveis. Posteriormente, Vesic (1963) acrescenta um terceiro modo de ruptura àqueles definidos por Terzaghi, que é o conceito de ruptura por puncionamento. Para fundações superficiais, o puncionamento ocorreria em solos fofos e moles.
\end{abstract}

A ruptura geral é caracterizada pela existência de uma superfície de deslizamento contínua que vai da borda da base do elemento estrutural de fundação e vai até a superfície do terreno (Figura 2.14). A ruptura é repentina e a carga última é bem definida. Observa-se deslocamento do solo na superfície e a ruptura é acompanhada por tombamento do elemento estrutural de fundação.

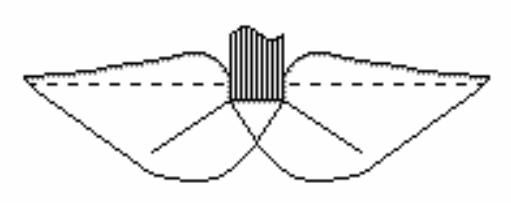

Figura 2.14 - Ruptura geral (Vesic, 1975)

Na ruptura por puncionamento, ao contrário, o solo externo à área carregada praticamente não é afetado e não há movimentação do solo na superfície (Figura 2.15). Com a aplicação da carga, o elemento estrutural tende a penetrar continuamente, em decorrência da compressão do solo subjacente. 


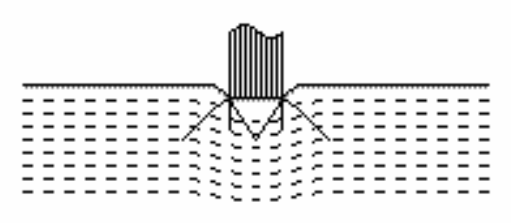

Figura 2.15 - Ruptura por puncionamento (Vesic, 1975)

A ruptura local é claramente definida apenas na base do elemento estrutural de fundação (Figura 2.16) e apresenta características dos outros dois modos de ruptura, constituindo-se num caso intermediário.

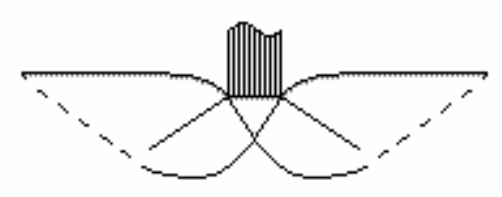

Figura 2.16-Ruptura local (Vesic, 1975)

Em solos arenosos, Vesic (1975) mostra que ao aumentar suficientemente a profundidade de apoio da base do elemento estrutural de fundação, passa a ocorrer apenas a ruptura por puncionamento, qualquer que seja o solo.

\section{Forma da curva carga-recalque em provas de carga estática}

A curva carga-recalque obtida em uma prova de carga estática, realizada em fundações diretas ou fundações por estacas, pode apresentar três formas bem características.

Na primeira, a curva mostra que, para pequenos recalques, atinge-se um valor de carga que impõe recalques incessantes (Figura 2.17). Trata-se de uma ruptura nítida. 
Na segunda forma, a curva determina uma assintota vertical, a qual caracteriza uma carga de ruptura correspondente a recalques praticamente infinitos (Figura 2.18). É a chamada ruptura física.

Em terceiro lugar, tem-se uma curva do tipo aberta, em que a carga cresce indefinidamente com a mobilização dos recalques. Neste caso, não se caracteriza uma ruptura propriamente dita. Denomina-se ruptura convencional e exige a aplicação de critérios arbitrários para se obter um valor de carga de "ruptura".

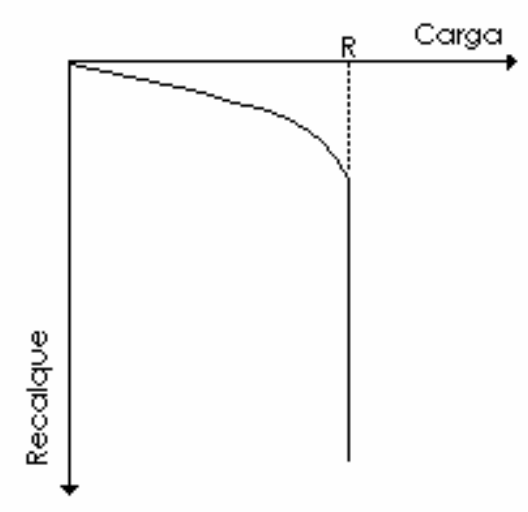

Figura 2.17 - Curva carga-recalque com ruptura nítida

Segundo Niyama et al. (1996), os critérios de ruptura existentes na literatura podem ser ordenados em quatro grupos:

1) Critérios da deformabilidade limite: a carga de ruptura corresponde à máxima relação entre a carga e o deslocamento. Ressalta-se o critério de Fuller \& Hoy (1970).

2) Critérios de inserção das fases elástica e plástica: se a curva carga-recalque é traçada em escala logarítmica, tenderá a duas retas cuja interseção define a carga de ruptura. Destacam-se os métodos de De Beer (1967) e Butler e Hoy (1977).

3) Critérios matemáticos: consiste na obtenção da carga de ruptura através do 
ajuste da curva carga-recalque com o auxilio de expressões matemáticas. Dentre eles estão os métodos de Chin (1970), Mazurkiewicz (1972) e Van de Veen (1953), sendo os dois últimos equivalentes. O método de Van der Veen é muito utilizado no Brasil e, além de definir a ruptura, permite extrapolar a curva.

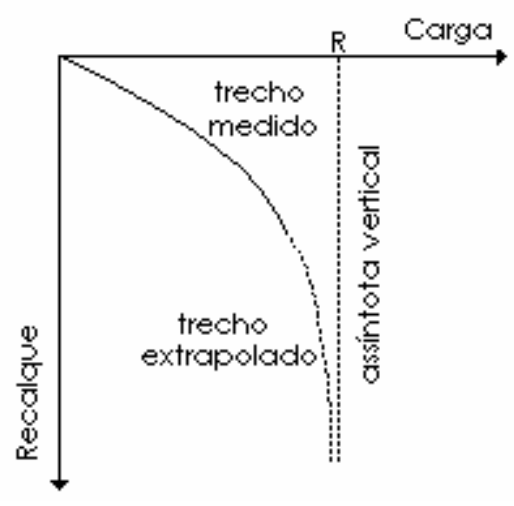

Figura 2.18 - Ruptura física

4) Critérios limitantes do deslocamento total: a carga de ruptura é fixada em função de um deslocamento pré-determinado. Podem-se destacar os critérios de Davisson (1972), da NBR 6122/96 e de alguns códigos de obras, como o da cidade americana de Boston, para a interpretação de ensaios em placa. Esse código estabelece que a tensão admissível é a menor entre dois valores: a tensão que corresponde a um recalque de $10 \mathrm{~mm}$ e a tensão que corresponde a um recalque de $25 \mathrm{~mm}$ dividida por dois. Teixeira e Godoy (1998) consideram o valor dois como um fator de segurança e, desta forma, a capacidade de carga é própria tensão que corresponde a um recalque de $25 \mathrm{~mm}$. O recalque de $10 \mathrm{~mm}$ seria uma espécie de recalque admissível.

\section{Extrapolação do ensaio em placa para sapatas}

Como o bulbo de tensões mobilizado pela placa é bem menos profundo que o bulbo de tensões de uma sapata instalada no mesmo local, submetida ao mesmo carregamento, só é aplicável extrapolar os dados obtidos no ensaio em placa para uma 
sapata, se o solo for razoavelmente uniforme em profundidade.

Em solo puramente coesivo, a capacidade de carga independe da dimensão e será a mesma para placa ou sapata. Para argilas sobreadensadas é razoável supor que, para uma mesma tensão aplicada, os recalques imediatos cresçam linearmente com a dimensão da sapata, pois o módulo de deformabilidade é constante com a profundidade e os bulbos são proporcionais à largura da placa e da sapata. De acordo com Cintra et al. (2003), obtido o recalque $\rho_{p}$ para uma placa circular de diâmetro $B_{p}$, para uma dada tensão $\sigma$ de interesse, o recalque imediato $\rho_{s}$ de uma sapata de diâmetro $B_{s}$, sob mesma tensão $\sigma$, será expresso por:

$$
\rho_{s}=\rho_{p} \frac{B_{s}}{B_{p}}
$$

Para areias, a capacidade de carga é proporcional à dimensão. Mas os recalques não aumentam em proporção direta com a dimensão, pois em solos não coesivos há aumento do módulo de deformabilidade com a profundidade. Com o aumento da dimensão da sapata, o bulbo de tensões passa a atingir profundidades maiores, com solos menos deformáveis.

No caso particular de o módulo de deformabilidade aumentar diretamente com a profundidade, os recalques da placa e da sapata serão iguais, para uma mesma tensão aplicada, pois o aumento do bulbo é compensado pelo aumento do módulo. O módulo de deformabilidade da areia varia entre este extremo (aumentando diretamente com o aumento da profundidade) e o outro extremo, que é o caso das argilas sobreadensadas (módulo constante com a profundidade). Assim, os recalques da sapata em areia serão maiores que os da placa, mas menores que os valores obtidos com a proporção direta do aumento da dimensão (Cintra et al., 2003). 


\subsection{COMPARAÇÃO ENTRE PROVA DE CARGA ESTÁTICA E DINÂMICA}

Aoki \& Niyama (1991) fazem uma avaliação comparativa entre as provas de carga dinâmica, de energia crescente, e estática rápida, realizadas em duas estacas de concreto centrifugado. Para a curva da prova de carga dinâmica, foi idealizado um procedimento de se traçar uma envoltória ligando os pares de valores RMX e DMX acrescido do deslocamento permanente acumulado, registrado com papel e lápis durante o ensaio. Os resultados deste procedimento podem ser vistos na Figura 2.19, onde também estão plotadas as curvas carga-deslocamento obtidas nas provas de carga estática (QML). A análise destes resultados mostra concordância bastante satisfatória, não somente quanto à carga de ruptura, mas também da curva carga-deslocamento. Atualmente, na interpretação de ensaios estáticos e dinâmicos, executados em uma mesma estaca, os deslocamentos permanentes observados ao final de cada ciclo não são mais acumulados.

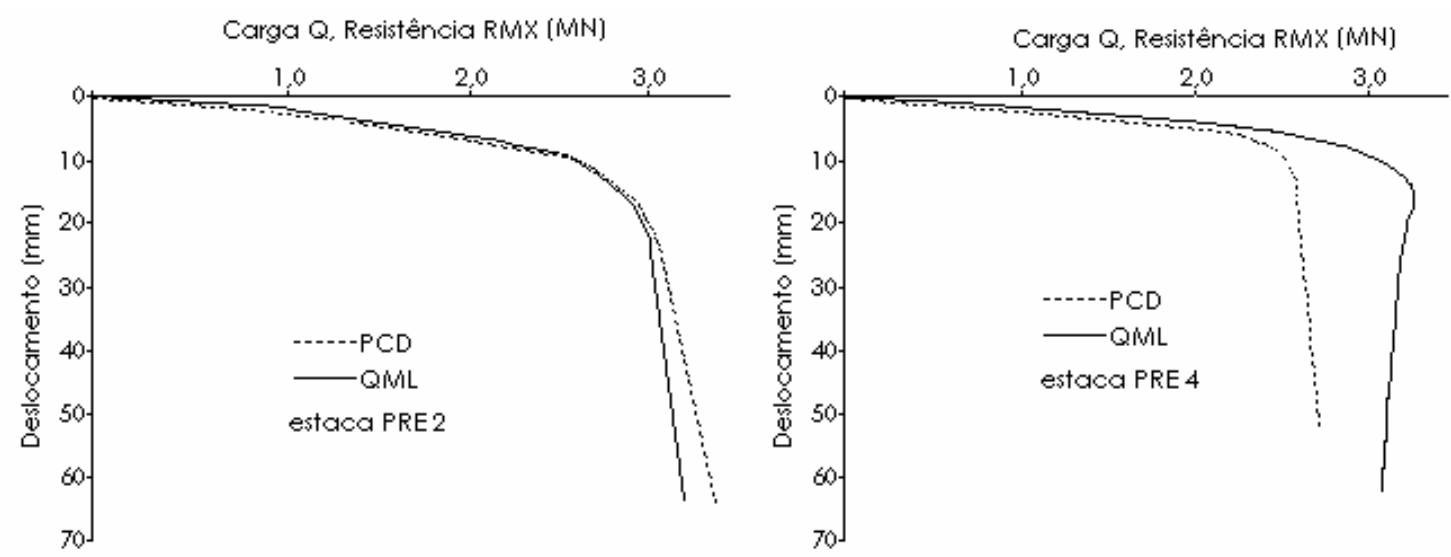

Figura 2.19 - Resultados de provas de carga dinâmica e estática em estacas (Niyama \& Aoki, 1991)

Rausche (1985) afirma que a capacidade de carga estática, determinada dinamicamente através do programa CAPWAP®, correlaciona bem com resultados medidos estaticamente em 69 estacas submetidas a provas de carga dinâmica e estática. 
Kormann et al. (2000) afirmam que uma comparação entre resultados de provas de carga estática e dinâmica, executadas em um mesmo elemento, não pode deixar de considerar que o primeiro ensaio modifica as condições da estaca. Assim, a comparação deve considerar os efeitos de cada ciclo de carregamento. Para tanto, podem-se acumular os deslocamentos permanentes observados ao final dos ensaios estáticos e após cada golpe do martelo. A aplicação deste conceito às curvas das provas de carga estática e às simulações do programa CAPWAP® de duas estacas ensaiadas apresentou, dentro de limites razoáveis, um bom resultado, como pode ser observado na Figura 2.20.

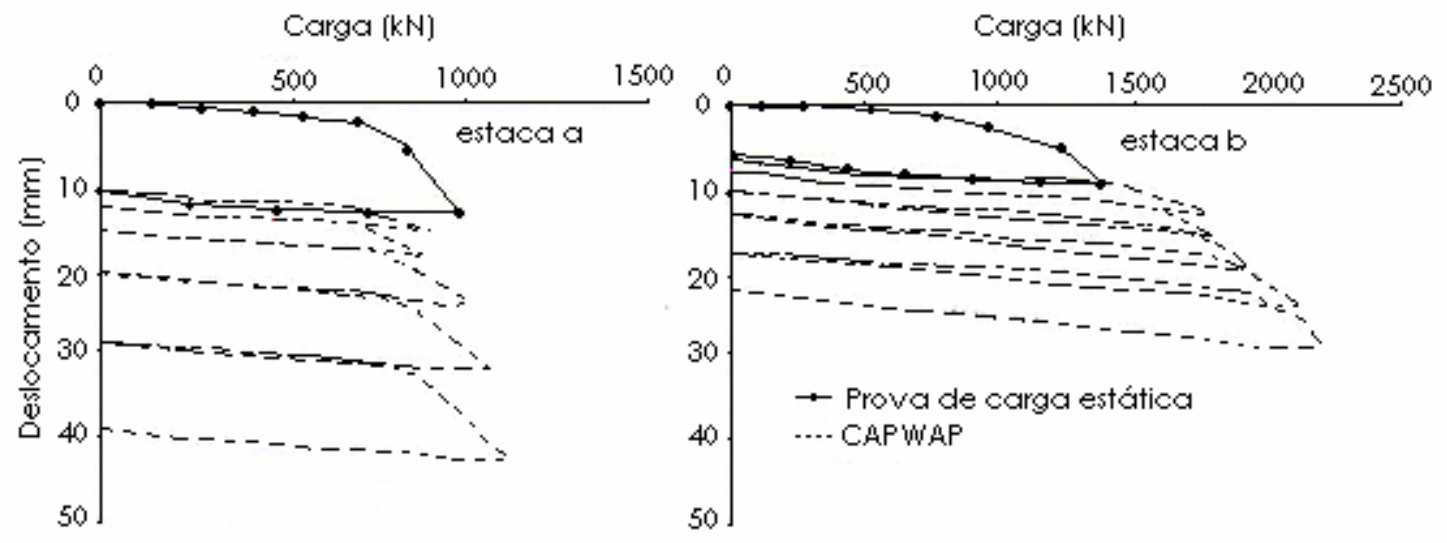

Figura 2.20 - Resultados de provas de carga estática e simulações no CAPWAP® em duas estacas (Kormann et al., 2000) 


\section{CAMPO EXPERIMENTAL DE FUNDACÕES}

As provas de carga foram realizadas no campo experimental do Departamento de Geotecnia da USP/São Carlos.

A cidade de São Carlos fica cerca de 800 m acima do nível do mar, sobre as rochas do Grupo São Bento, compostas por arenitos da Formação Botucatu e Pirambóia e derrames de efusivas basálticas da Formação Serra Geral (Bortolucci, 1983).

O campo experimental está situado no extremo sul do campus da USP/São Carlos, em uma área cujo perfil geológico-geotécnico é considerado representativo da região centro-oeste do estado de São Paulo (Cintra et al., 1991). A Figura 3.1 mostra o perfil geológico de parte da cidade de São Carlos e a localização do campus da USP.

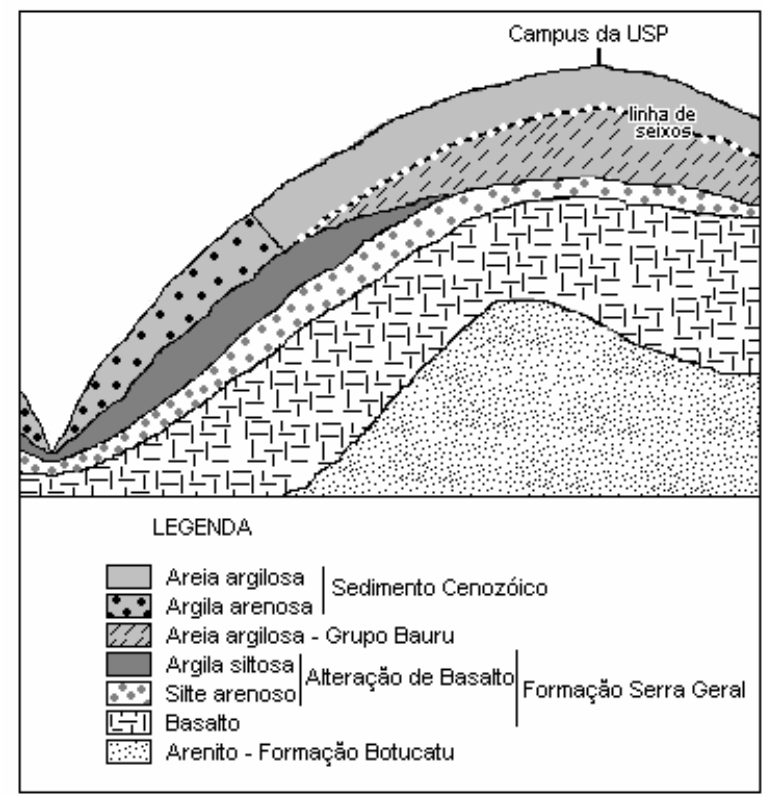

Figura 3.1 - Seção esquemática da geologia de pequena profundidade em São Carlos (Bortolucci, 1983) 
A área desse campo foi caracterizada geotecnicamente através de diversos ensaios laboratoriais e in situ, dentre os quais uma campanha de cinco sondagens de simples reconhecimento (SPT) e cinco ensaios de penetração estática (CPT). Giachetti et al. (1993) apresentam um estudo dos resultados obtidos.

O perfil de solo típico do campo é composto por uma camada superficial de areia fina argilosa marrom (sedimento cenozóico), com 6 m de espessura, pouco compacta, muito porosa e colapsível, com Nspt variando entre 1 e 5 golpes, separada da camada de solo residual do Grupo Bauru (areia fina argilosa vermelha), por uma linha de seixos de 0,3 m de espessura. O nível d'água varia de 7 a $10 \mathrm{~m}$ de profundidade entre os períodos mais úmidos e mais secos durante o ano (Cintra, 1998). A Figura 3.2 mostra os resultados de ensaios penetrométricos SPT, ao longo do perfil de solo (adaptado de Machado, 1998).

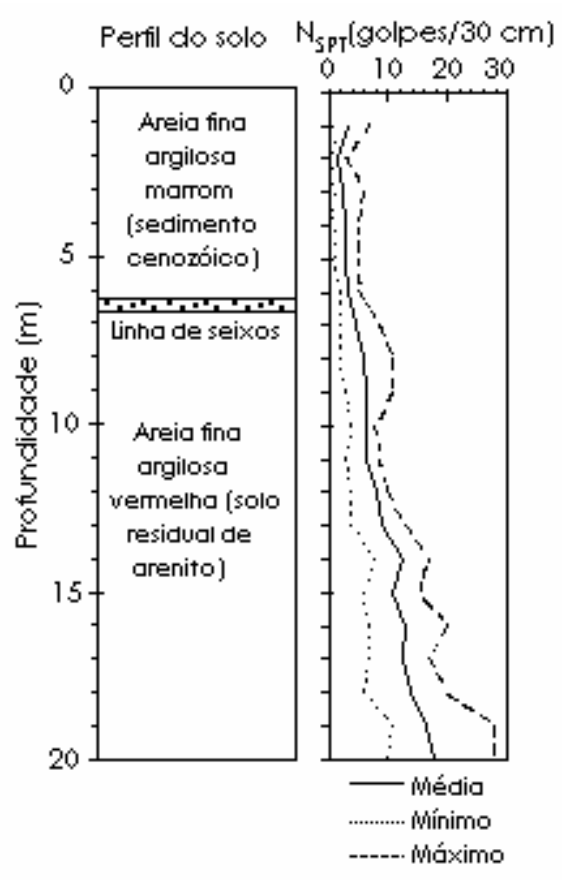

Figura 3.2 - Resultados de ensaios de SPT ao longo do perfil de solo (adaptado de Machado, 1998) 
Muitas pesquisas já foram realizadas neste campo, com a realização de provas de carga dinâmica em tubulões e provas de carga estática à compressão em tubulões, grupos de estacas e em estacas isoladas de diversos tipos e com diferentes geometrias, à tração e com carregamento horizontal em alguns tipos de estacas, além de provas de carga estática em sapatas e em placas em várias profundidades e diferentes dimensões.

As pesquisas consideram o solo em condição não inundada (inclusive monitorandose a pressão de sucção matricial durante os ensaios) e na condição de solo inundado artificialmente, para quantificação da redução da capacidade de carga da fundação por efeito da colapsibilidade do terreno, que é característica marcante do solo superficial da região centro-oeste do estado de São Paulo e de várias outras regiões brasileiras. Vilar (1979) comprovou a colapsibilidade do sedimento cenozóico a partir da realização de diversos ensaios de adensamento edométrico em laboratório. Machado (1998), através de ensaios de laboratório, obteve curvas características de secagem do solo do campo, a partir de amostras indeformadas coletadas a 2, 5 e $8 \mathrm{~m}$. A Figura 3.3 mostra a curva obtida para a profundidade de $2 \mathrm{~m}$. 


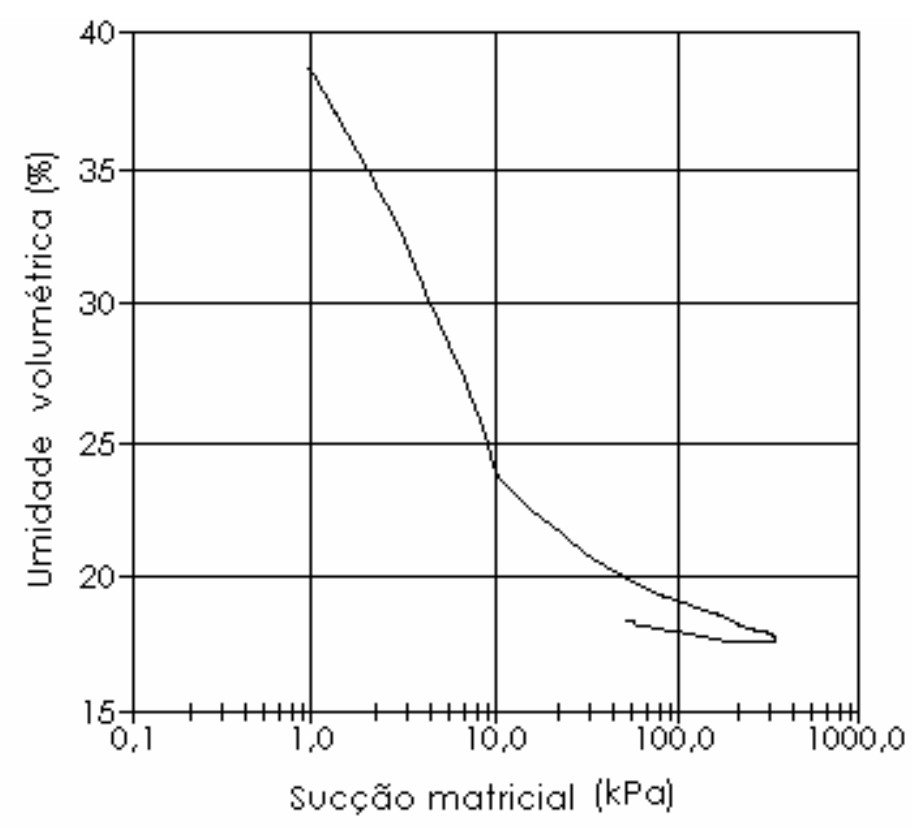

Figura 3.3 - Curva característica de sucção (Machado, 1998)

Nas provas de carga estática realizadas em placas, sapatas e tubulões no terreno do campo experimental, observa-se que as curvas carga-recalque não caracterizam ruptura nítida, sistematicamente. No trecho final das curvas há uma mobilização crescente de resistência com o aumento do recalque, de forma praticamente linear.

Benvenutti (2001), fazendo sucessivas provas de carga estática em tubulão nesse terreno, mostra que, além de não haver definição de ruptura nítida, ocorre aumento da capacidade de carga do sistema, com a penetração do tubulão no solo. Conforme as Figuras 3.4 e 3.5, obtidas por Benvenutti (2001), com e sem inundação prévia, respectivamente, pode-se observar que a parte final das curvas carga-recalque de três ensaios sucessivos de um mesmo tubulão constituem aproximadamente um único trecho reto. 


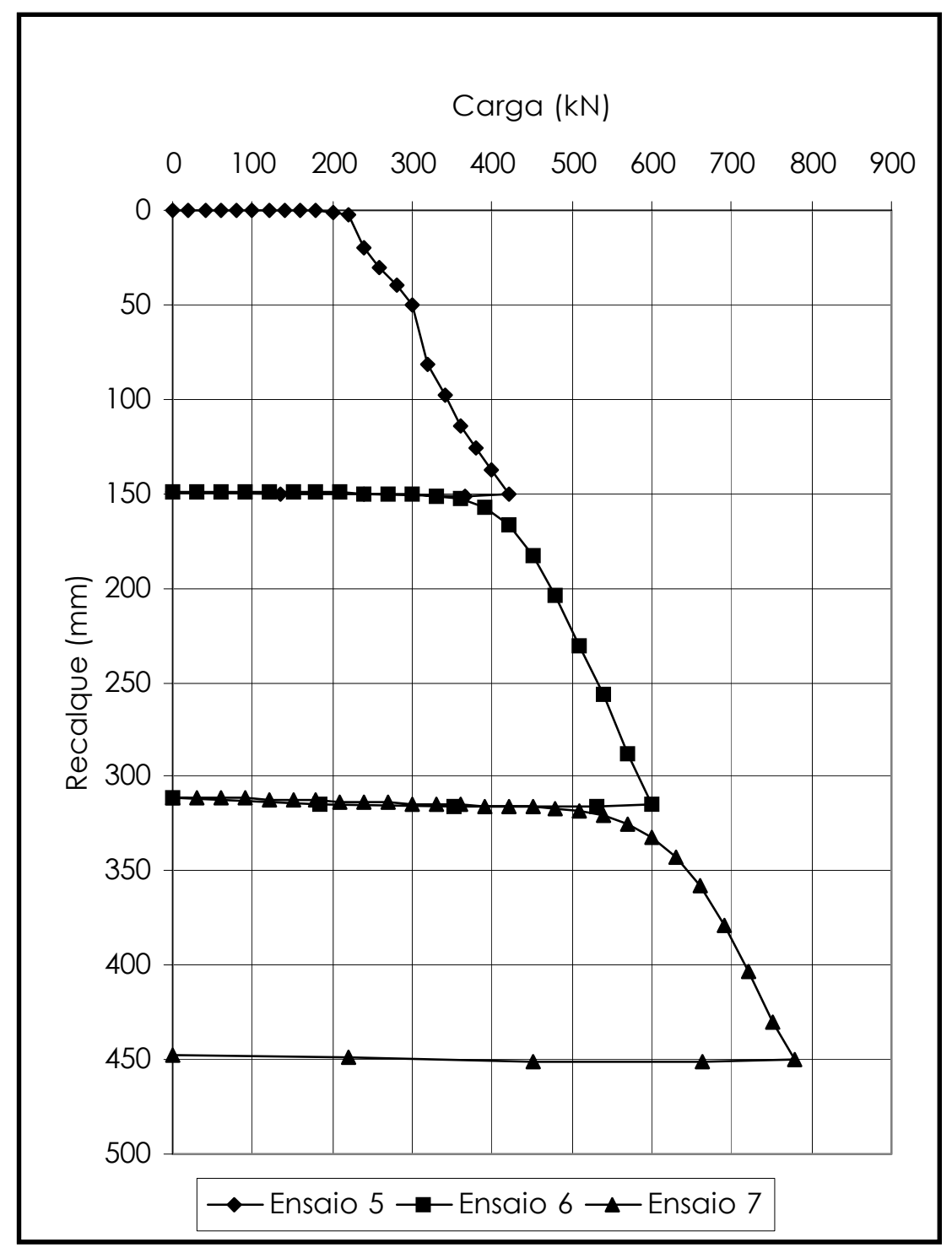

Figura 3.4 - Curvas carga-recalque de três ensaios em tubulão a céu aberto, com solo previamente inundado (Benvenutti, 2001) 


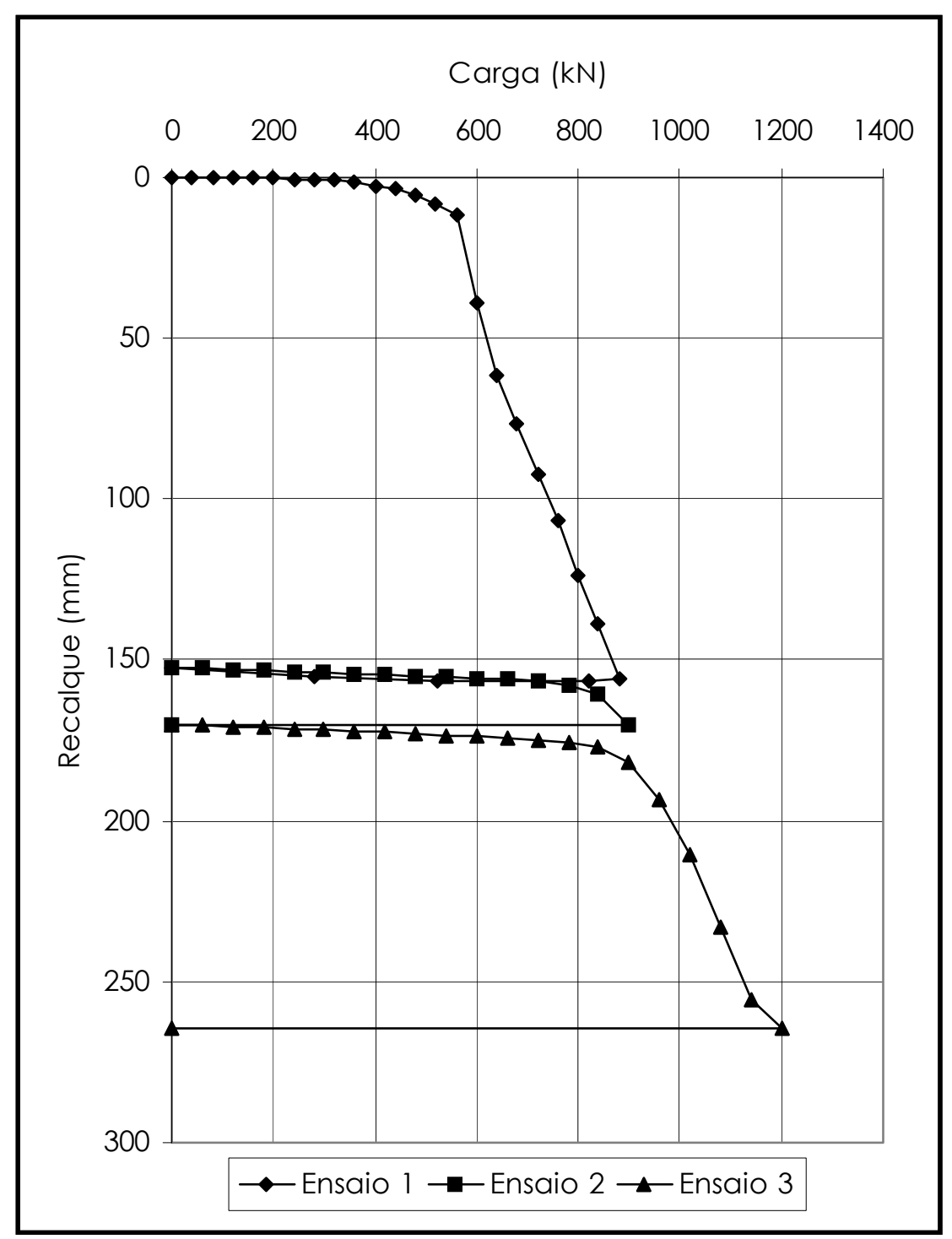

Figura 3.5 - Curvas carga-recalque de três ensaios em tubulão a céu aberto, com solo não inundado (Benvenutti, 2001) 


\section{MATERIAIS E MÉTODOS}

Foram realizadas nove provas de carga dinâmica e quatro provas de carga estática, em placa metálica, rígida, circular, com diâmetro de 0,80 m. Os ensaios foram feitos em nove cavas de 0,90 a 1,00 m de diâmetro com 1,5 m de profundidade. Uma das cavas foi usada para verificação da sucção matricial e as demais para a realização das provas de carga. A Figura 4.1 mostra a disposição das cavas abertas no terreno do Campo Experimental de Fundações da USP/São Carlos.

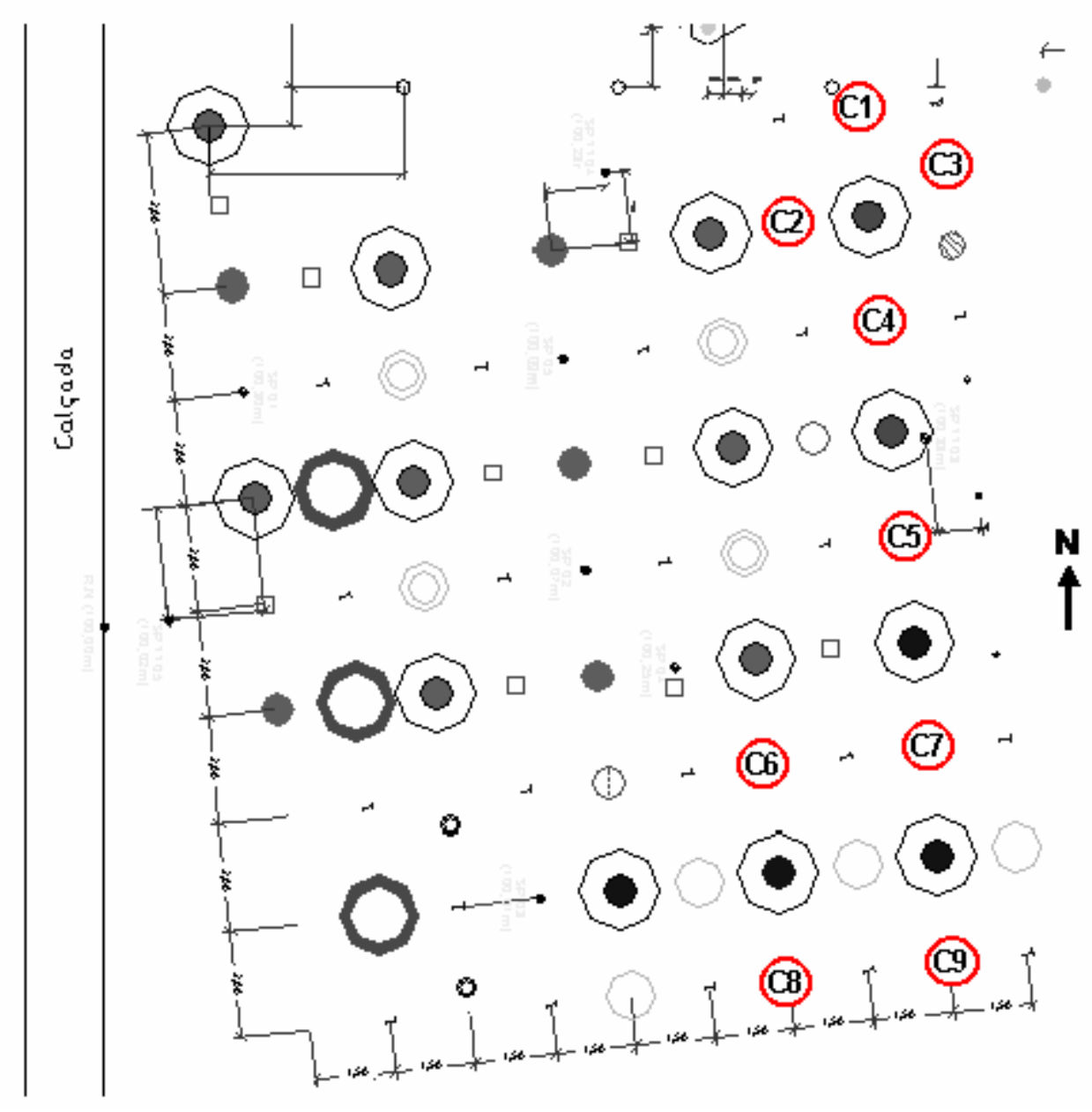

Figura 4.1 - Disposição das cavas usadas nos ensaios em placa no Campo Experimental da USP/São Carlos 
Nas cavas 4, 9, 7 e 8 (C4, C9, C7 e C8), foram feitas provas de carga dinâmica e estática, sendo que em C7 e C8 em terreno previamente inundado.

Nas cavas 1 e 3 (C1 e C3) foram realizadas provas de carga dinâmica, com penetração de $30 \%$ do diâmetro da placa.

Na cava 6 (C6) foi realizada uma prova de carga dinâmica, em terreno inundado, posteriormente à realização de outra prova de carga dinâmica, em terreno não inundado.

Na cava 5 (C5) foi feito um monitoramento da pressão de sucção matricial durante o período de realização dos ensaios.

\subsection{PROVAS DE CARGA DINÂMICA}

Foram realizadas nove provas de carga dinâmica de energia crescente em placa metálica, em oito cavas abertas no terreno do campo experimental.

Cada golpe do martelo foi acompanhado por monitoramento dinâmico utilizando-se o mesmo esquema usualmente empregado em estacas pré-moldadas, que será descrito neste capítulo.

\subsubsection{ADAPTAÇÃO DO ENSAIO}

A placa de aço circular utilizada tem $25 \mathrm{~mm}$ de espessura e 0,80 m de diâmetro, resultando em uma área de $0,50 \mathrm{~m}^{2}$ de contato com o solo. Para que tenha uma maior rigidez, a chapa possui um ressalto central; uma chapa circular também de aço, com 25 
mm de espessura e 0,30 m de diâmetro soldada à placa.

Para tornar possível o uso da mesma instrumentação dinâmica comumente utilizada para estacas, a placa foi ligada a um tubo de aço com $7 \mathrm{~m}$ de comprimento, com diâmetro externo igual a 0,22 m e parede de 0,008 m. A área de aço da secção transversal do tubo escolhido é superior à necessária em termos de resistência à compressão e flambagem. O comprimento do tubo foi escolhido com base em simulações do comportamento de uma onda de deformação percorrendo um tubo de aço com o auxílio de um programa computacional de aplicação da equação da onda desenvolvido por Aoki (1989).

Na ponta inferior do tubo foi soldada uma flange com diâmetro interno igual a 0,22 $\mathrm{m}$ e externo 0,30 m. Essa flange foi parafusada à placa. As Figuras 4.2 e 4.3 mostram a ligação do tubo com a placa.

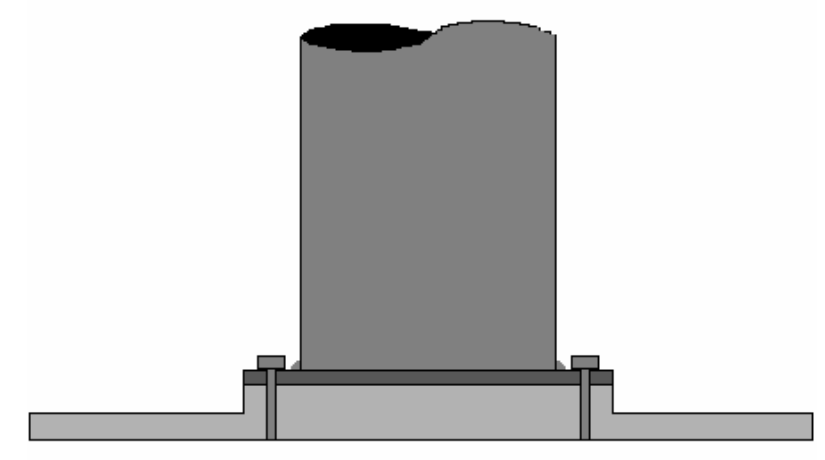

Figura 4.2 - Esquema da ligação tubo-placa 

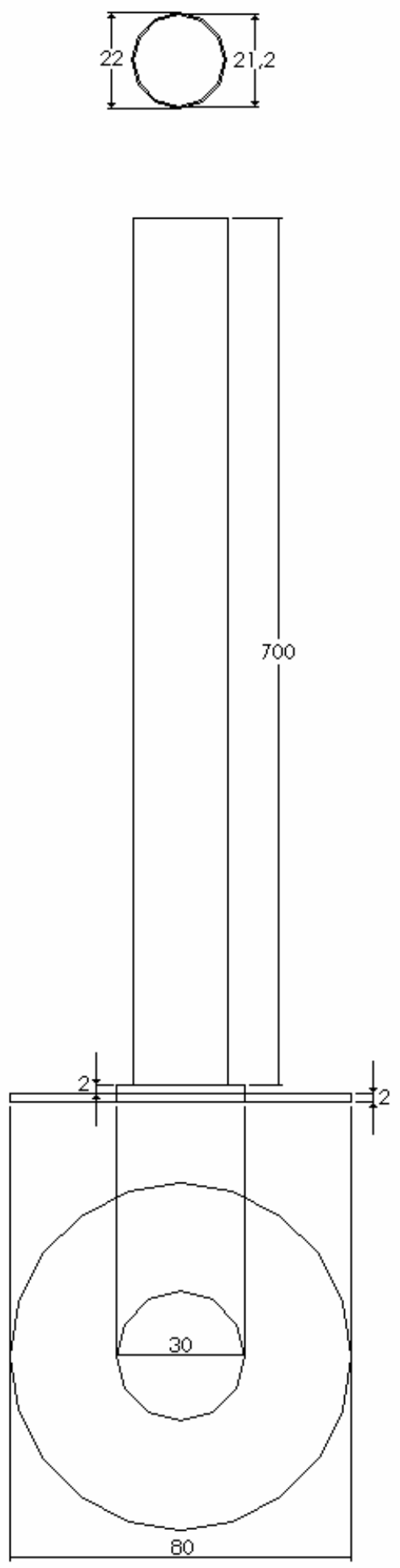

Figura 4.3 - Peça utilizada nos ensaios (tubo-placa) 


\subsubsection{INSTRUMENTAÇÃO UTILIZADA}

O esquema utilizado é um dos mais difundidos para realizar a instrumentação dinâmica, e usa o sistema PDA (Pile Driving Analyzer) - composto por dois acelerômetros, dois transdutores de deformação específica e um analisador de cravação. Os equipamentos utilizados foram fabricados e comercializados pela empresa PDI, Inc. Os acelerômetros são do tipo piezoelétrico, com amplificador incorporado e os transdutores de deformação consistem de quatro strain-gauges colados em um suporte de alumínio.

Os sensores foram colocados inicialmente a três metros do topo da estaca. A partir do segundo ensaio a instrumentação foi mudada para $0,60 \mathrm{~m}$ do topo da estaca. Tanto os acelerômetros quanto os transdutores de deformação foram instalados na parede do tubo em posições diametralmente opostas para compensar os efeitos de momento fletor. A Figura 4.4 mostra a furação do tubo e os sensores já instalados.
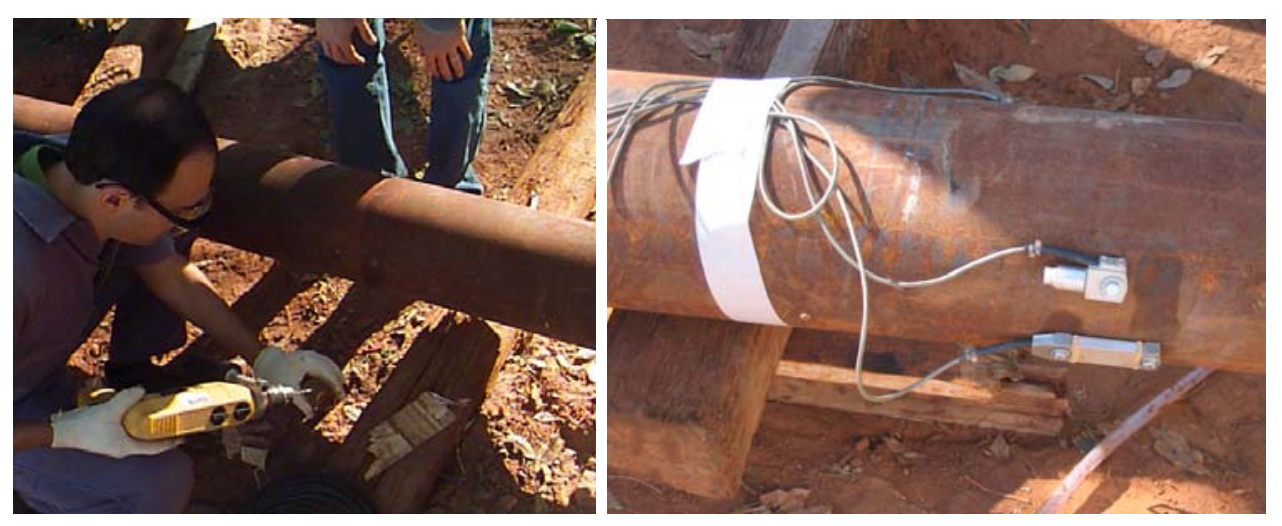

Figura 4.4 - Instalação dos sensores

Os sinais obtidos são enviados para o analisador através de um cabo blindado. Os de aceleração, por integração no tempo, fornecem a velocidade calculada na seção instrumentada, ao longo do tempo: 


$$
v=\int a \cdot d t
$$

Uma nova integração no tempo fornece o deslocamento calculado na seção instrumentada:

$$
w=\iint a \cdot d t \cdot d t=\int v \cdot d t
$$

Os sinais de deformação, por multiplicação pela área da seção transversal e módulo de deformabilidade do tubo (aço), fornecem a força na seção instrumentada, ao longo do tempo:

$$
F=\varepsilon \cdot E \cdot A
$$

Os sinais enviados pelos instrumentos são processados pelo PDA, que pode calcular vários parâmetros de interesse, sendo o principal a resistência estática à penetração da estaca no solo, através do método simplificado CASE ou CAPWAP®.

O CAPWAP® (Case Pile Wave Analysis Program) é o programa mais utilizado para estimativa da capacidade de carga e distribuição da resistência ao longo da profundidade, em estacas, a partir de dados de medições de força e aceleração.

Através do método CAPWAP®, o sistema tubo-placa-solo foi modelado por uma série de massas e molas para a obtenção da previsão da carga estática mobilizada durante o golpe do martelo. O conjunto tubo-placa foi modelado como uma estaca de ponta alargada com atrito lateral igual a zero. Não se permitiu que o programa distribuísse a resistência ao longo da profundidade. 


\subsubsection{ANALISADOR - PILE DRIVING ANALYSER (PDA)}

Antes de iniciar o monitoramento dinâmico com o PDA, é necessário fornecer algumas informações sobre a "estaca" a ser ensaiada, tais como, a área da seção transversal, o comprimento abaixo dos sensores e o comprimento de embutimento. Como o tubo ensaiado era de aço, o PDA fornecia o módulo de deformabilidade, a velocidade da onda de tensão e o peso específico, pois para o aço esses valores são praticamente constantes.

Durante o impacto do martelo, a resistência mobilizada, golpe a golpe, foi analisada pelo método CASE. Posteriormente foram realizadas análises CAPWAP® também de todos os golpes. A Figura 4.5 mostra o equipamento utilizado.

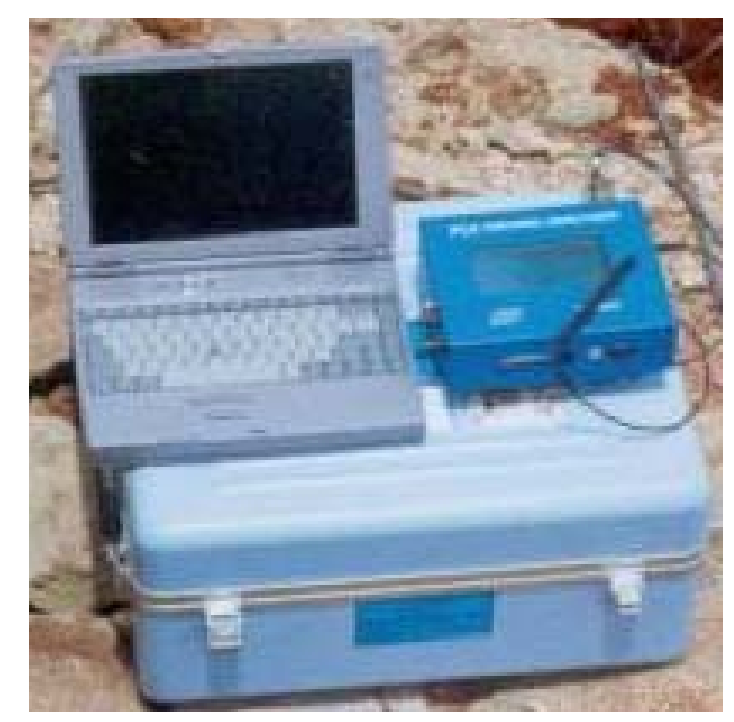

Figura 4.5 - Pile Driving Analyzer (PDA) 


\subsubsection{SISTEMA DE IMPACTO E AMORTECIMENTO}

Um bate-estacas de queda livre com martelo de $15 \mathrm{kN}$ efetuou as várias seqüências de golpes, com alturas de queda crescentes. O capacete utilizado pesava $5 \mathrm{kN}$, com cepo de madeira de $30 \mathrm{~cm}$ de espessura e coxim de madeirit de $25 \mathrm{~mm}$. Durante a realização do primeiro ensaio (cava 4) foi colocado um cepo extra (madeirit) de $35 \mathrm{~mm}$ (que foi mantido em todos os ensaios), para aumentar o amortecimento e melhorar a qualidade dos sinais obtidos. O bate-estacas utilizado pode ser visto na Figura 4.6, que mostra uma vista geral do ensaio. Na Figura 4.7 tem-se um desenho esquemático da prova de carga dinâmica.



Figura 4.6 - Vista geral do ensaio 


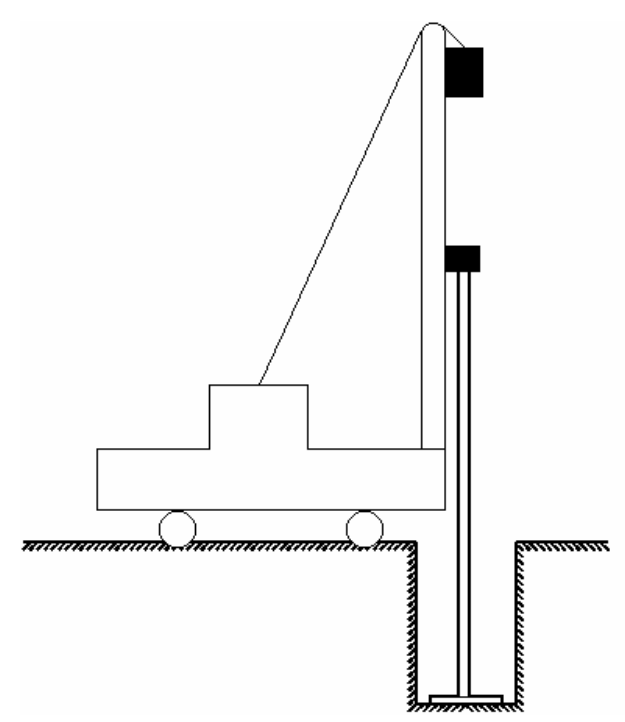

Figura 4.7 - Desenho esquemático do bate-estacas e da peça dentro da cava

\subsubsection{ENSAIOS COM TERRENO INUNDADO}

A inundação do terreno deu-se mediante a condução de água potável proveniente da rede pública até o fundo da cava, por gravidade. Cinco das provas de carga dinâmica foram realizadas em terreno pré-inundado por no mínimo 12 horas, mantendo-se uma lâmina d'água de pelo menos $20 \mathrm{~cm}$. Na cava 6, uma prova de carga dinâmica havia sido realizada antes da inundação, e tornou-se a realizar o ensaio após a inundação. Nas cavas 1, 6, 7 e 8, a prova de carga dinâmica foi realizada somente após a inundação do terreno. A Figura 4.8 mostra o conjunto de mangueiras e conexões usado na distribuição da água. 


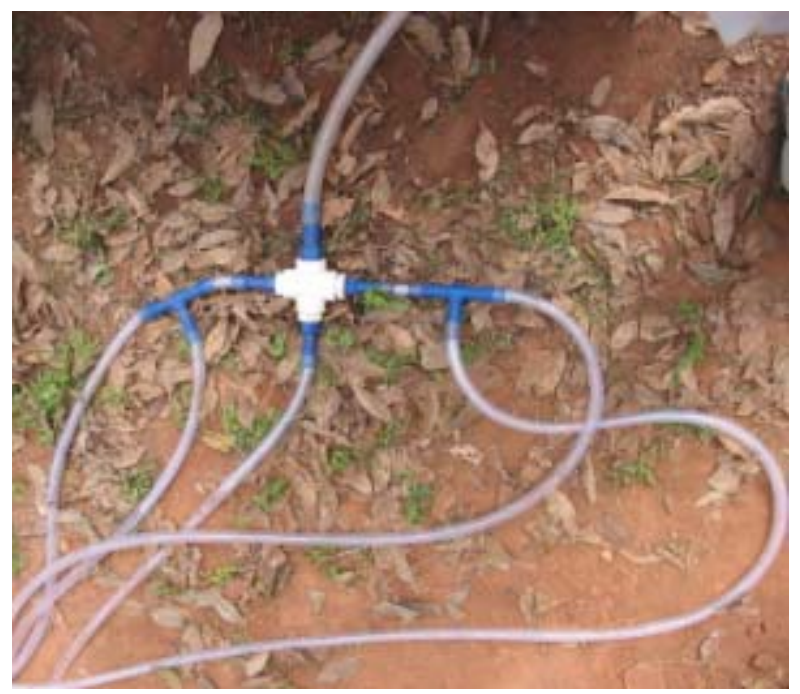

Figura 4.8 - Distribuição da água

\subsubsection{MEDIÇÃO DE NEGA}

Paralelamente ao monitoramento dinâmico, foram feitas medidas de nega através do uso de papel e lápis. Foi fixado um papel na parede do tubo na altura da borda da cava. Para cada golpe do martelo, o lápis registrava o deslocamento permanente. Não foi possível registrar o deslocamento elástico (repique), pois, no momento dos golpes, o tubo apresentava um pequeno movimento horizontal. A Figura 4.9 mostra a medição da nega. 


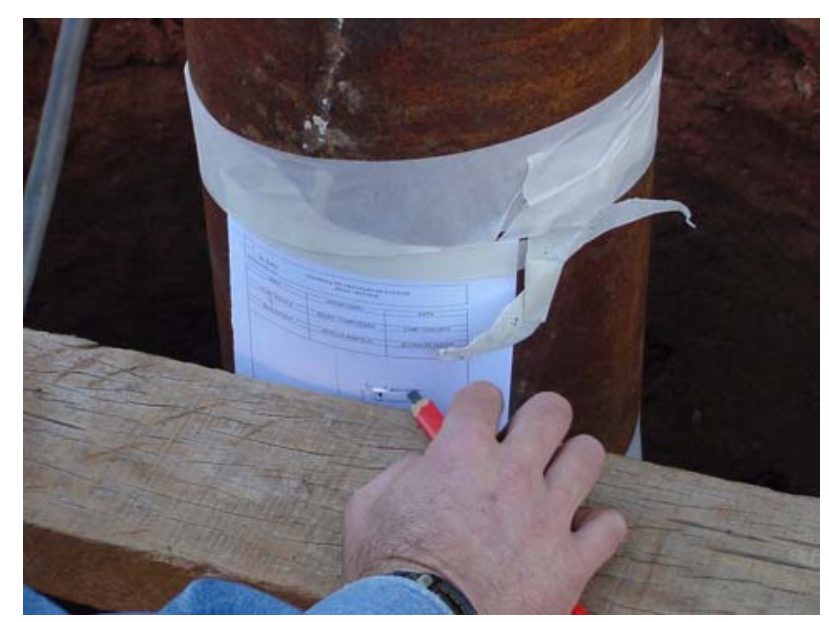

Figura 4.9 - Medição da nega

\subsubsection{SEQÜÊNCIA DE REALIZAÇÃO DAS} PROVAS DE CARGA DINÂMICA

Os ensaios foram realizados nos dias 15 e 16 de julho de 2004. No primeiro dia foram realizados os ensaios em cavas não inundadas na seguinte ordem: cavas 4, 2, 6, 9 e 3. A seqüência foi escolhida em função das distâncias entre as cavas de modo a movimentar o bate-estacas somente o necessário. Como a prova de carga dinâmica é um ensaio muito rápido, o maior consumo de tempo é dado pelo deslocamento do bate-estacas.

As cavas 1, 6, 7 e 8 foram inundadas durante toda a noite, e ensaiadas no dia seguinte nessa ordem. A cava 6 havia sido ensaiada no primeiro dia e foi reensaiada em condição inundada. O mesmo estava previsto para a cava 2, porém com a inundação, observou-se fuga d'água e formação de uma cratera próxima à parede da cava, com 1 m de profundidade (Figura 4.10), impedindo a realização do ensaio. Optou-se por descartar o ensaio feito em condição não inundada nesta cava, já que não havia o ensaio inundado para comparação. 


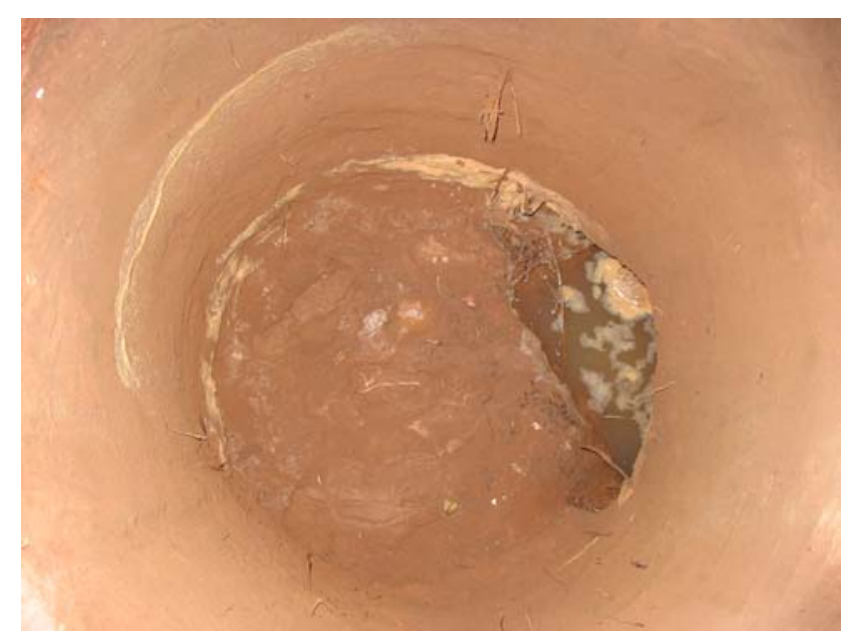

Figura 4.10 - Cava 2 (danificada)

As alturas de queda foram escolhidas com base em previsões das provas de carga dinâmica feitas a partir de extrapolação de curvas carga-recalque de provas de carga estática realizadas por Costa (1999) no mesmo local. A Tabela 4.1 mostra as alturas de queda de cada ensaio.

Tabela 4.1 - Alturas de queda das provas de carga dinâmica em cm

\begin{tabular}{|c|c|c|c|c|c|c|c|c|}
\hline Cava 1 & Cava 2 & Cava 3 & Cava 4 & Cava 6 & Cava 6 & Cava 7 & Cava 8 & Cava 9 \\
\hline (Ensaio 6) & (Ensaio 2) & (Ensaio 5) & (Ensaio 1) & (Ensaio 3) & (Ensaio 7) & (Ensaio 9) & (Ensaio 8) & (Ensaio 4) \\
\hline 100 & 30 & 150 & 30 & 30 & 30 & 40 & 35 & 30 \\
\hline 75 & 25 & 125 & 30 & 25 & 25 & 35 & 30 & 25 \\
\hline 50 & 20 & 100 & 25 & 20 & 20 & 30 & 25 & 20 \\
\hline 20 & 15 & 75 & 20 & 15 & 15 & 25 & 20 & 15 \\
\hline 10 & 12,5 & 50 & 15 & 12,5 & 12,5 & 20 & 15 & 12,5 \\
\hline & 10 & 20 & 12,5 & 10 & 7,5 & 15 & 12,5 & 10 \\
\hline & 7,5 & 10 & 10 & 7,5 & 5 & 12,5 & 10 & 7,5 \\
\hline & \multirow[t]{7}{*}{5} & & 7,5 & 5 & & 10 & 7,5 & 5 \\
\hline & & & 5 & 2,5 & & 7,5 & 5 & 2,5 \\
\hline & & & 10 & & & 5 & & \\
\hline & & & 7,5 & & & & & \\
\hline & & & 5 & & & & & \\
\hline & & & 2,5 & & & & & \\
\hline & & & 2,5 & & & & & \\
\hline
\end{tabular}

Tentou-se começar os ensaios com altura de queda igual a $2,5 \mathrm{~cm}$, mas como o PDA não registrava o golpe com energia tão baixa, os ensaios do segundo dia tiveram altura de queda a partir de $5 \mathrm{~cm}$. Para as cavas 1 e 3 , as alturas de queda foram maiores, para que se 
atingisse uma penetração igual a 30\% do diâmetro da placa.

Como as alturas de queda necessárias para obter os níveis de energia previstos eram pequenas, foram confeccionados gabaritos em PVC com cada altura. A Figura 4.11 mostra a utilização de um deles.

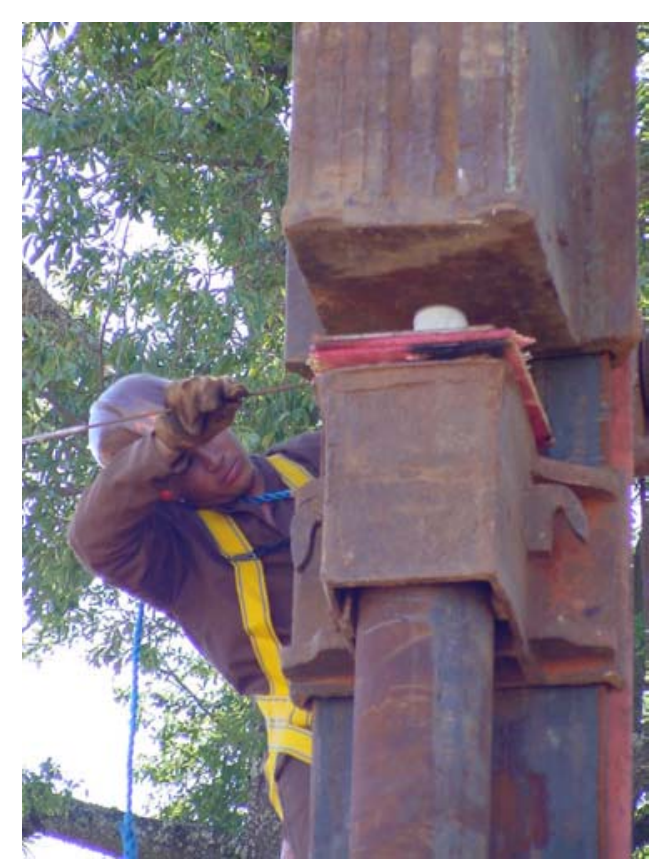

Figura 4.11 - Utilização do gabarito de PVC

\subsection{PROVAS DE CARGA ESTÁTICA}

Foram realizadas quatro provas de carga estática em placa de aço circular rígida de 0,80 m de diâmetro, em quatro das cavas usadas nos ensaios dinâmicos. Em dois ensaios o terreno foi pré-inundado por no mínimo 12 horas mantendo-se sempre uma lâmina d'água de pelo menos $20 \mathrm{~cm}$ no fundo da cava. Durante os ensaios a lâmina foi mantida.

As provas de carga estática foram realizadas com carregamento do tipo rápido (QML - Quick Maintained Load) de acordo com a NBR 12131/91, porém com estágios de 15 
minutos de duração, segundo a proposição de Fellenius (1975). Durante cada estágio a carga era mantida e as leituras de recalque eram obtidas nos tempos de $0,1,2,3,6,9,12$ e 15 min; o descarregamento foi realizado em dois estágios de 15 minutos. Antes do descarregamento, deixou-se de repor a carga até a estabilização da carga e dos recalques.

Outras provas de carga estática em placa de aço de 0,80 m haviam sido realizadas por Costa (1999) nas mesmas cavas, uma com carregamento lento (SML - Slow Maintained Load), uma com carregamento rápido e duas com carregamento misto (lento até a tensão admissível provável e rápido a partir dessa). Os ensaios realizados nas cavas usadas nesta pesquisa tiveram terreno previamente inundado por 24 horas mantendo uma lâmina d'água de $0,50 \mathrm{~m}$. Costa (1999) também tem outras provas de carga estática em cavas próximas com diferentes níveis de sucção. Optou-se por usar nas comparações com a atual pesquisa, dois ensaios realizados em condições mais parecidas com as provas de carga estática atuais, um deles, ensaio rápido em terreno inundado (denominado QS1), feito na cava 8, foi usado nas comparações com as cavas inundadas 7 e 8, e o outro, ensaio rápido em terreno não inundado com sucção igual a $15 \mathrm{kPa}$ (denominado Q1), feito numa cava a 2,5 m da cava 9, foi usado nas comparações com as cavas não inundadas 4 e 9. A Figura 4.12 mostra as curvas tensão-recalque dos ensaios QS1 e Q1. 


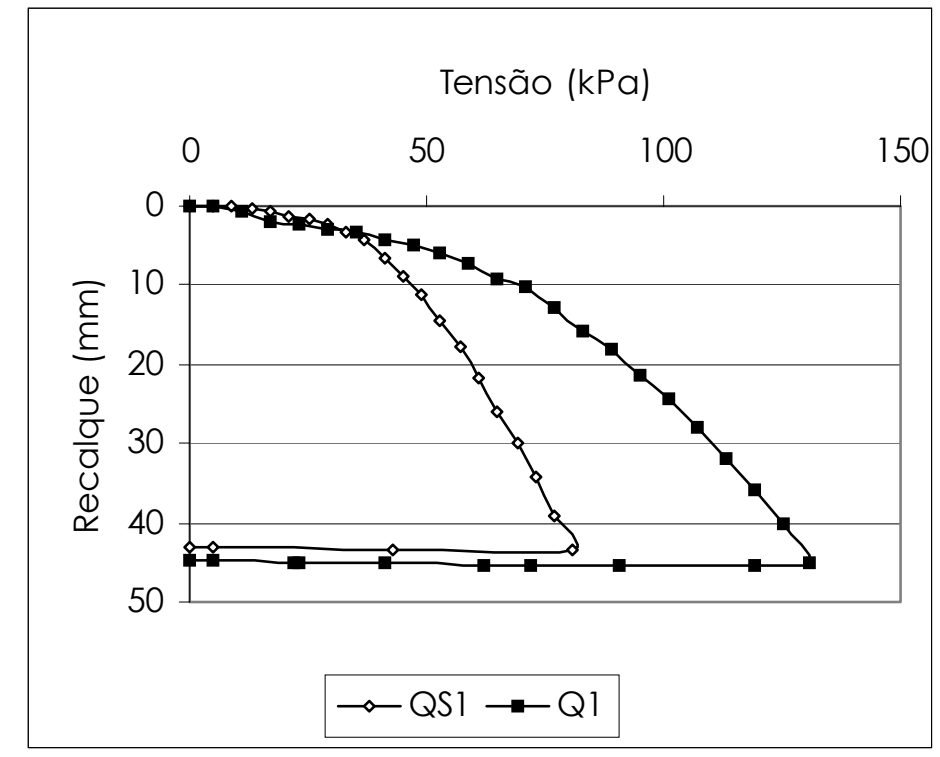

Figura 4.12 - Curvas tensão-recalque (Costa, 1999)

\subsubsection{EQUIPAMENTOS E MATERIAIS}

\section{UTILIZADOS}

\section{Placa}

A mesma placa das provas de carga dinâmica foi também utilizada nas provas de carga estática, após remoção do tubo adaptado para o ensaio dinâmico.

\section{Macaco Hidráulico e Bomba}

Para aplicação do carregamento, utilizou-se um macaco hidráulico com capacidade para 200 kN, cujo acionamento era efetuado por uma bomba elétrica (Figura 4.13). 


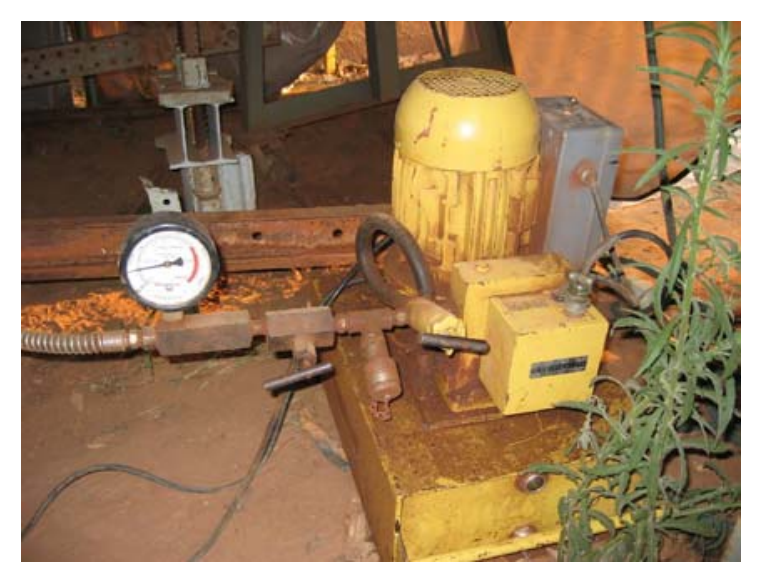

Figura 4.13 - Bomba hidráulica

\section{Célula de carga}

Foi utilizada uma célula de carga da marca Transdutec com capacidade para 200 kN. A curva de calibração da célula de carga é apresentada no Apêndice A. A Figura 4.14 mostra a célula de carga (azul) sobre o macaco hidráulico (amarelo).

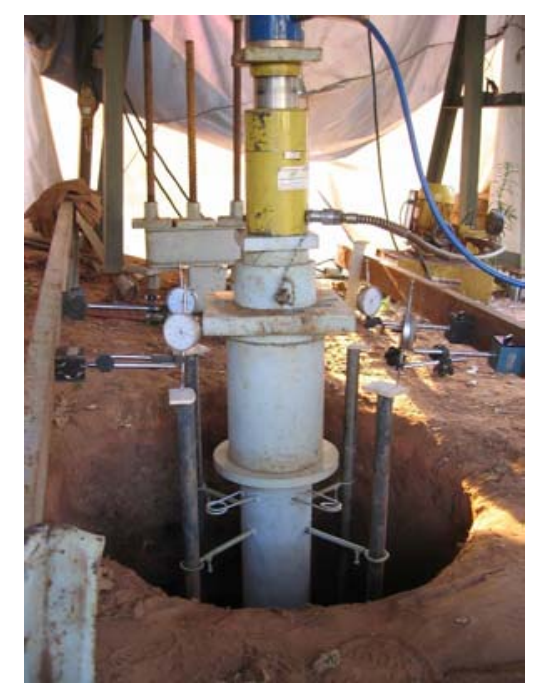

Figura 4.14 - Montagem da prova de carga estática

\section{Indicador de deformações}

Para as leituras das deformações específicas dos strain-gauges instalados na célula 
de carga, foi usado um indicador de deformações da marca Transdutec, modelo T832, com resolução de $1 \mu$ strain e capacidade de leitura de $\pm 50000 \mu$ strain (Figura 4.15).

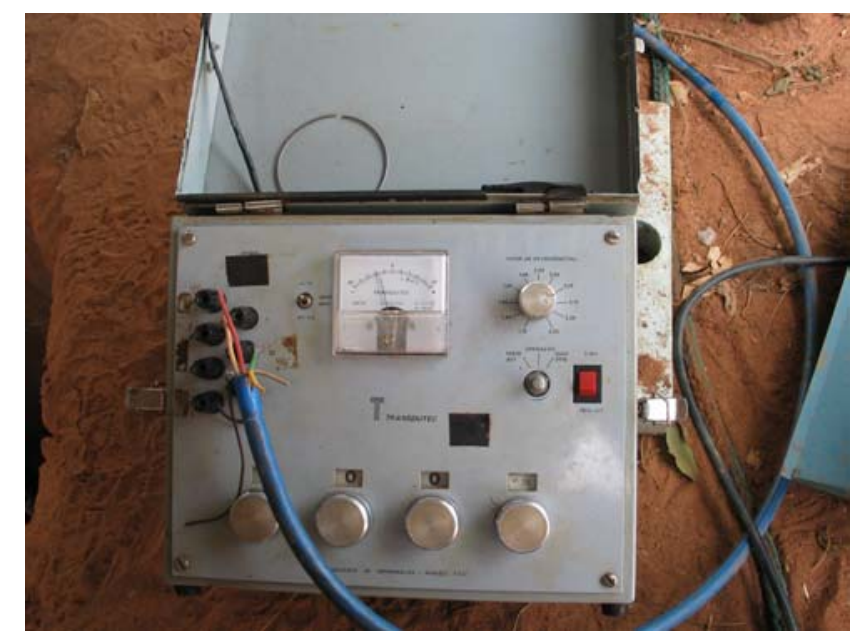

Figura 4.15 - Indicador de deformações

\section{Torre de transferência de carga}

Para transferir a carga aplicada pelo macaco hidráulico foi utilizada uma torre de aço, composta por um cilindro de 1,53 m de altura, com diâmetro externo igual a $170 \mathrm{~mm}$ e parede de $10 \mathrm{~mm}$ de espessura, e dois discos de $25 \mathrm{~mm}$ de espessura com diâmetro igual a 0,30 m, soldados nas extremidades do cilindro. Os discos permitem uma melhor distribuição da carga.

\section{Extensômetros mecânicos}

Para as leituras dos recalques foram usados quatro extensômetros da marca Mitutoyo, com resolução de $0,01 \mathrm{~mm}$ e curso total de $50 \mathrm{~mm}$. O extensômetros foram instalados com o auxílio de bases magnéticas articuláveis. Para ligar os extensômetros à placa foram usadas quatro hastes de aço que eram encaixadas em argolas soldadas à torre de transferência de carga. No topo de cada haste foi colada uma placa de azulejo, que serviu de apoio para os extensômetros. Os azulejos, além de terem superfície bastante 
regular e lisa, minimizando o atrito com a ponteira do extensômetro, sofrem pouquíssima variação de volume com a oscilação da temperatura.

\section{Guias de referência}

Como sistema de referência para medição dos recalques, foram utilizadas duas vigas de aço de $3,3 \mathrm{~m}$ de comprimento, cada uma parafusada a dois pontaletes de aço cravados no solo. Nas vigas, que são perfis $U$, foram fixadas as bases magnéticas dos extensômetros.

\subsubsection{SISTEMA DE REAÇÃO}

O sistema de reação era formado por uma viga metálica, a qual transferia a carga aplicada pelo macaco a uma composição de barras do tipo dywidag de $32 \mathrm{~mm}$ de diâmetro. As barras transmitiam a carga às estacas de reação (metálicas do tipo trilho TR-68, com 27 m de comprimento e carga admissível à tração de 550 kN).

A viga de reação utilizada possui seção transversal em I, com 300 x 650 mm, 3,30 m de comprimento e capacidade de suporte de 800 kN. Entre a célula de carga e a viga de reação foi utilizada uma rótula de aço para a conservação da normalidade do carregamento (Figuras 4.16 e 4.17). 


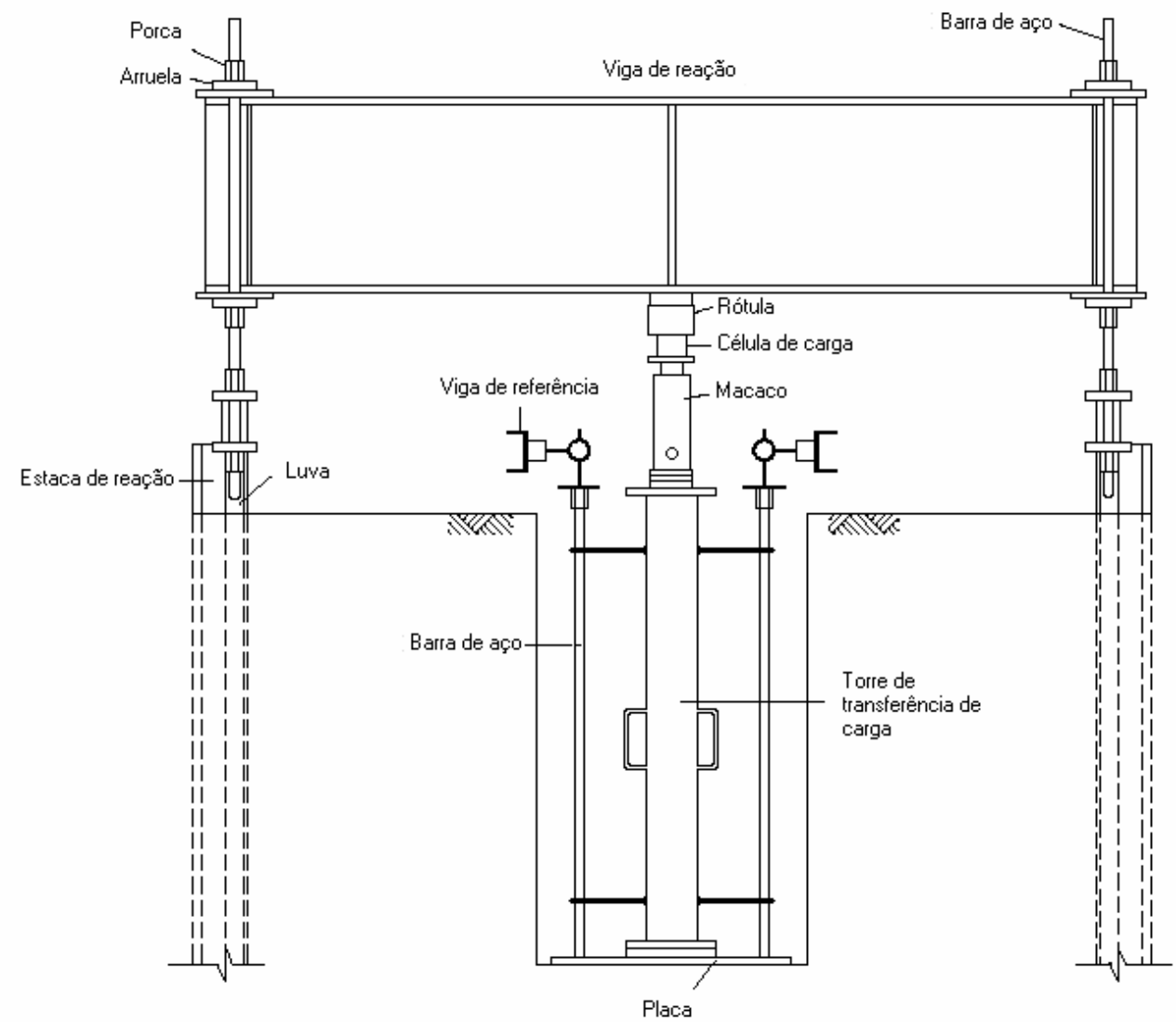

Figura 4.16 - Esquema de montagem das provas de carga estática realizadas
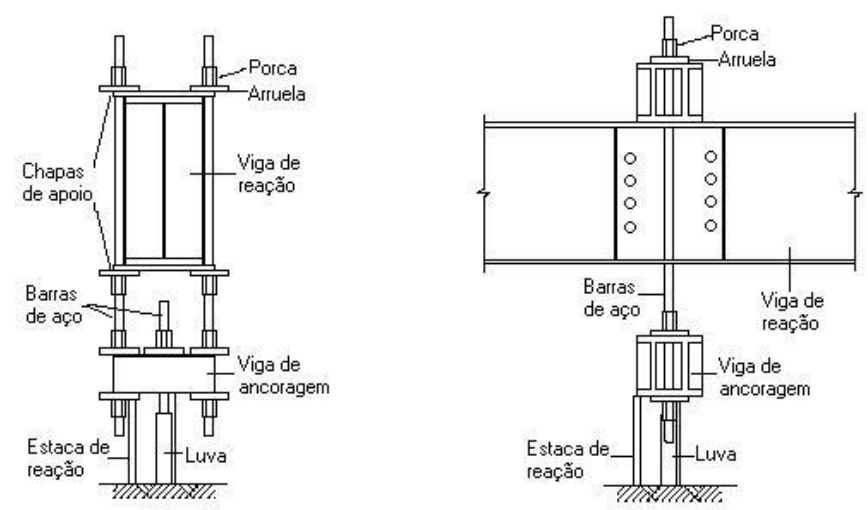

Figura 4.17 - Esquemas do sistema de reação vistos em corte transversal 


\subsection{MEDIDAS DE SUCÇÃO MATRICIAL}

Durante o período em que foram realizados os ensaios, leituras periódicas da sucção matricial foram feitas em tensiômetros da marca Soil Moisture instalados na cava 5. Os tensiômetros permaneceram instalados nessa cava durante quatro meses.

Por praticidade, optou-se por instalar todos os tensiômetros numa cava de controle, que não seria utilizada nos ensaios, mas que foi aberta nas mesmas condições e próxima das outras usadas nas provas de carga.

Foram utilizados quatro tensiômetros, instalados a 0,20 m de profundidade, acoplados a quatro vacuômetros. O tipo de tensiômetro usado tem um reservatório no topo (jet fill) que facilita a complementação do nível de água destilada no tubo, além de ajudar na remoção de bolhas de ar. Uma bomba de vácuo portátil foi usada no momento da instalação para evitar que restassem bolhas de ar nos equipamentos.

A instalação dos tensiômetros foi feita com o auxílio de um trado manual com diâmetro ligeiramente inferior ao do tubo. Nos últimos centímetros, procedeu-se uma prensagem, visando garantir o contato da pedra porosa com o solo. A Figura 4.18 mostra a disposição dos tensiômetros na cava 5 . 


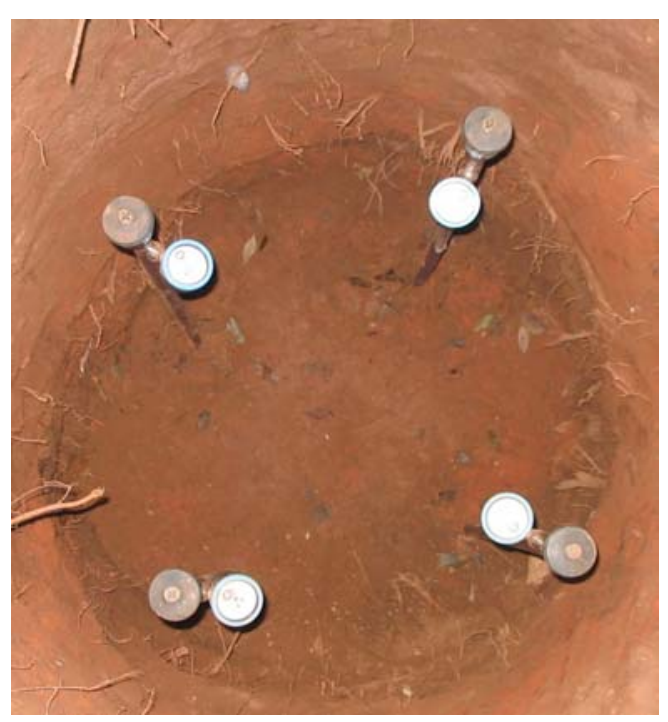

Figura 4.18 - Disposição dos tensiômetros na cava 5 


\section{RESULTADOS}

A seguir são apresentados os resultados das oito provas de carga dinâmica e quatro provas de carga estática.

\subsection{PROVAS DE CARGA DINÂMICA EM PLACA}

Os resultados das provas de carga dinâmica são apresentados nas Figuras 5.1 a 5.8. As curvas resistência $\mathrm{x}$ deslocamento das provas de carga dinâmica representam os valores de resistência obtidos através do método simplificado CASE - RMX obtido utilizando-se Jc igual a 0,25 para os ensaios não inundados e 0,40 para os ensaios inundados - e os deslocamentos máximos de cada golpe (DMX).

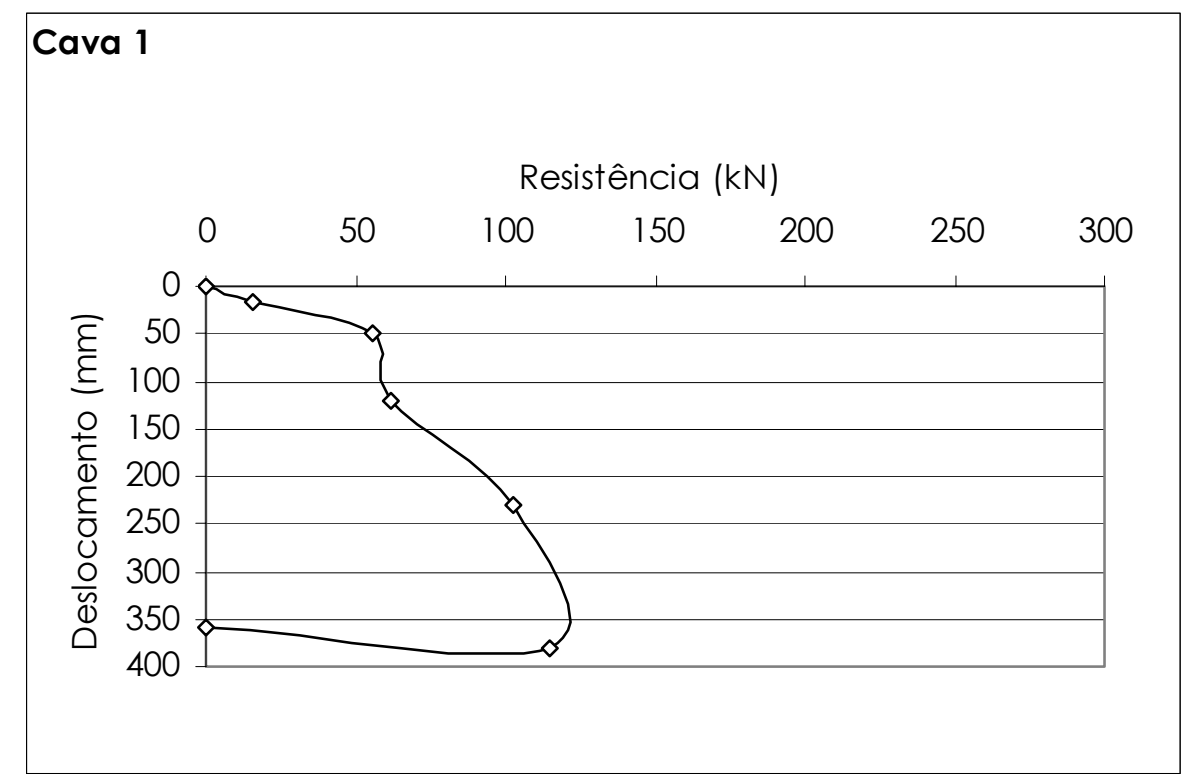

Figura 5.1 - Curva resistência mobilizada x deslocamento (cava 1, terreno inundado) 


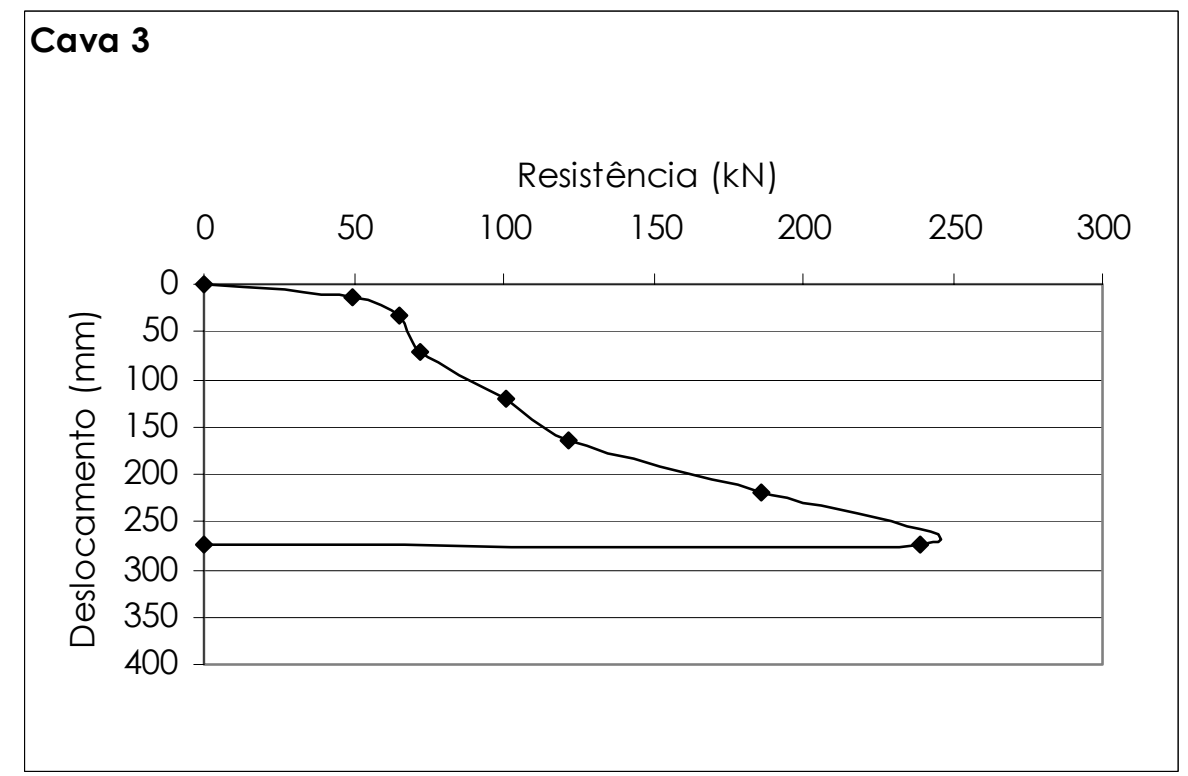

Figura 5.2 - Curva resistência mobilizada x deslocamento (cava 3, terreno não inundado)

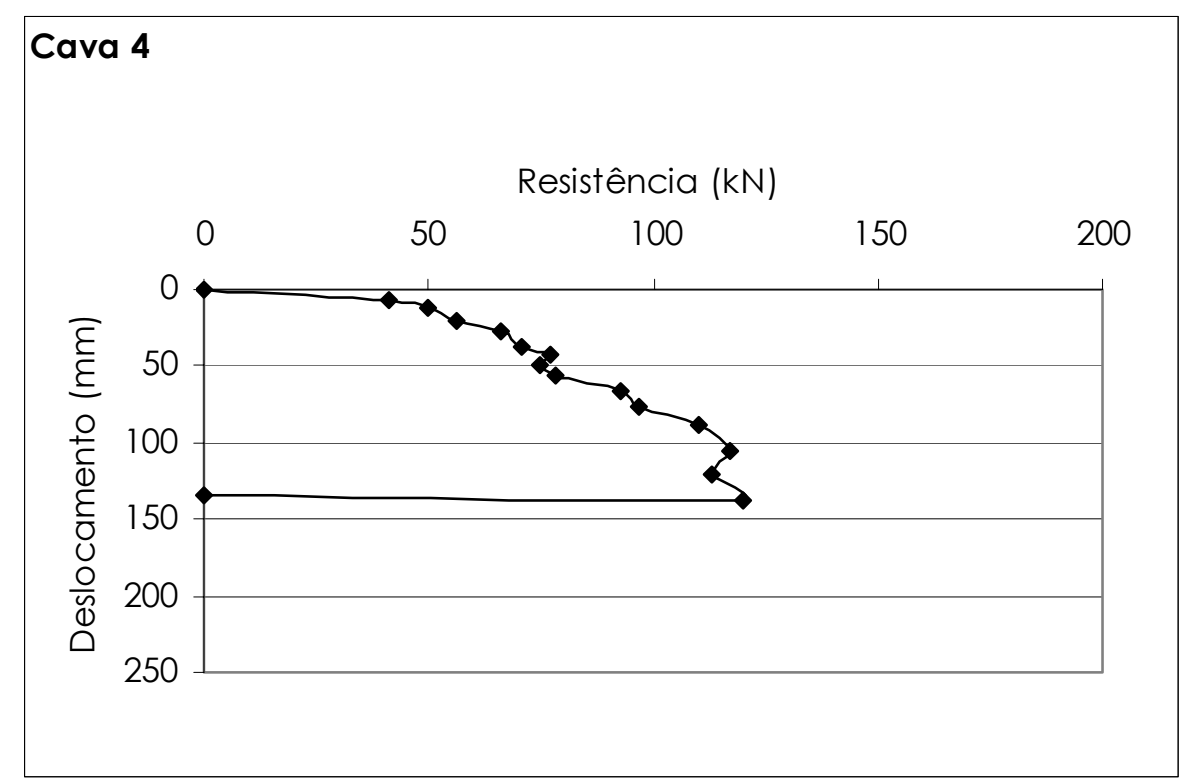

Figura 5.3 - Curva resistência mobilizada x deslocamento (cava 4, terreno não inundado) 


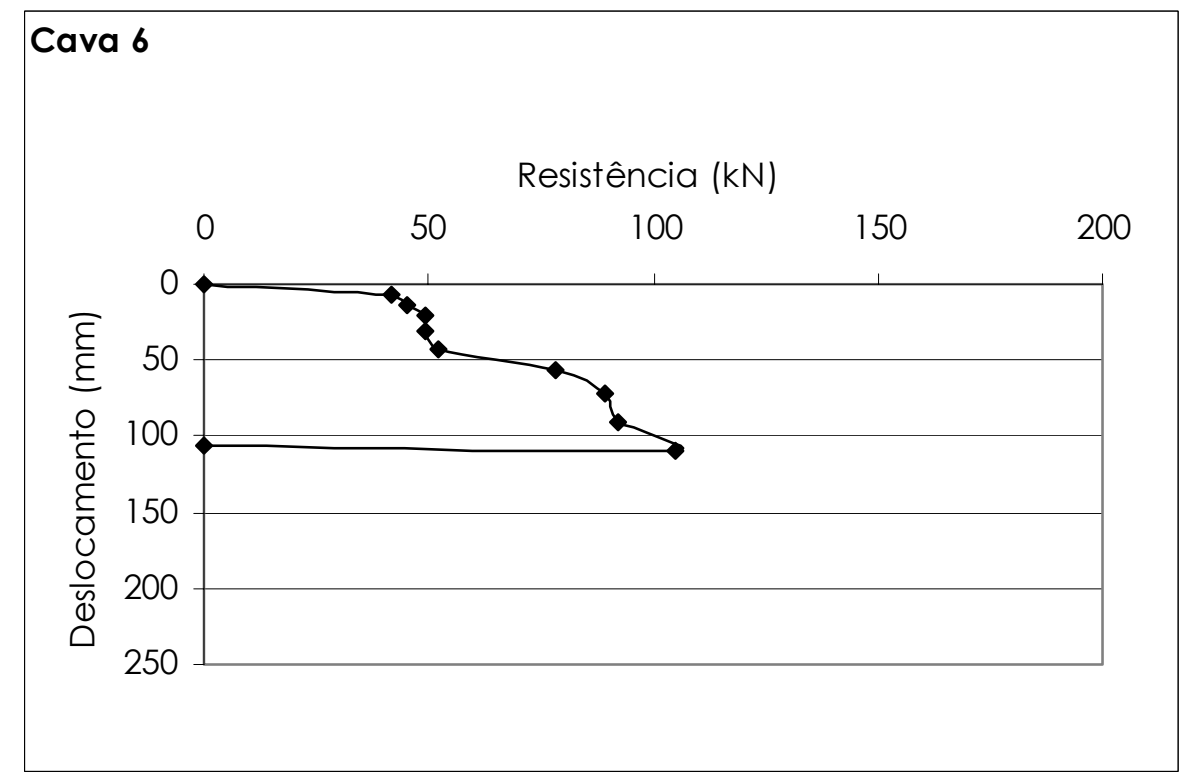

Figura 5.4 - Curva resistência mobilizada x deslocamento (cava 6, terreno não inundado)

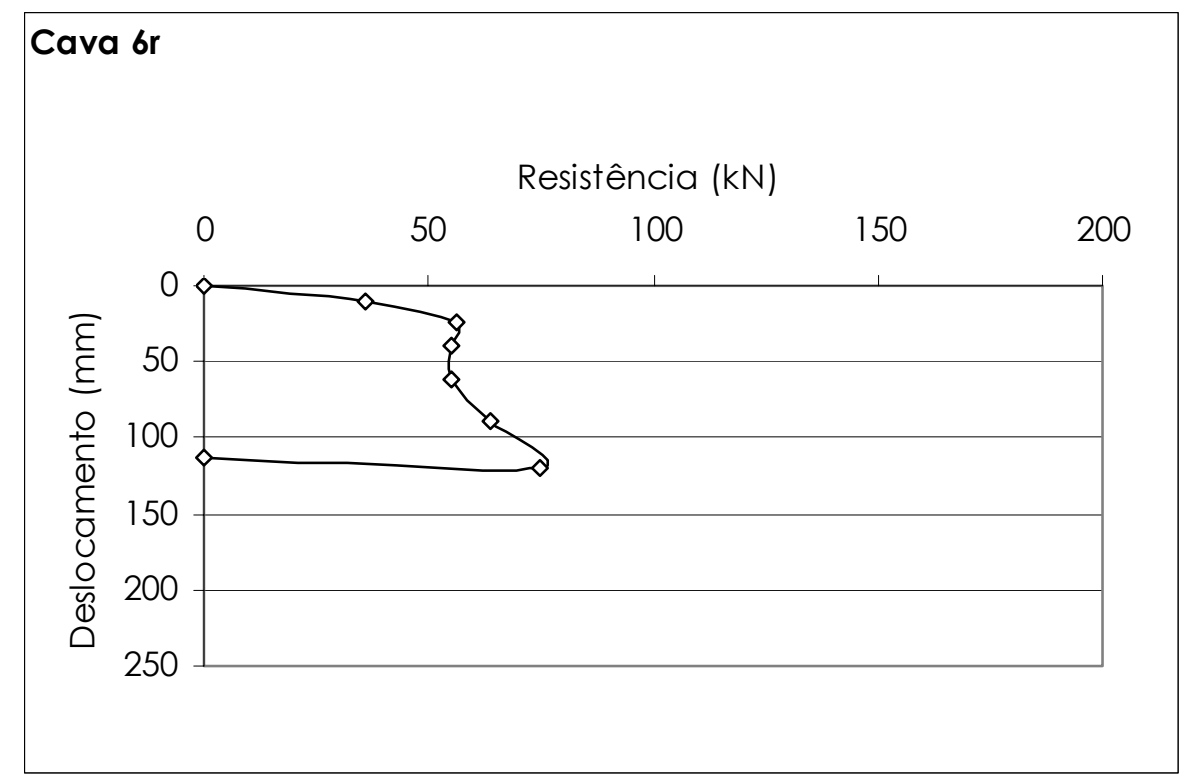

Figura 5.5 - Curva resistência mobilizada x deslocamento (cava 6, terreno inundado) 


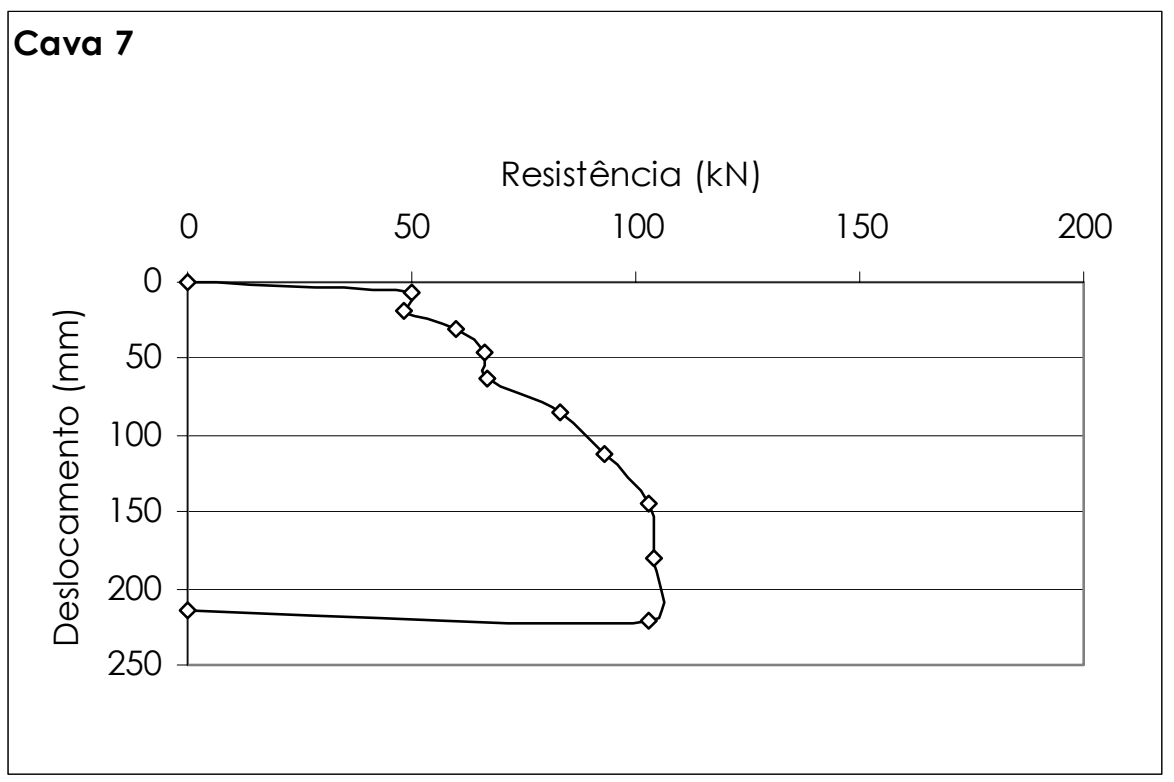

Figura 5.6 - Curva resistência mobilizada x deslocamento (cava 7, terreno inundado)

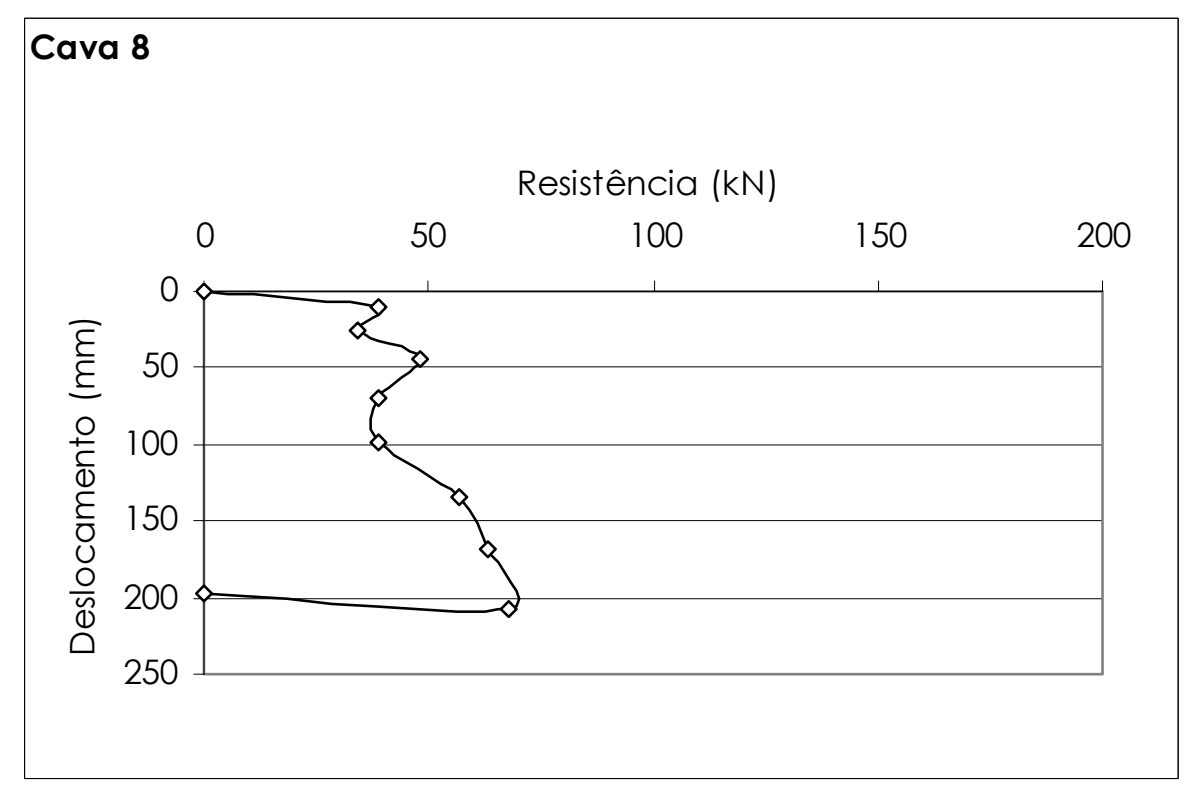

Figura 5.7 - Curva resistência mobilizada x deslocamento (cava 8, terreno inundado) 


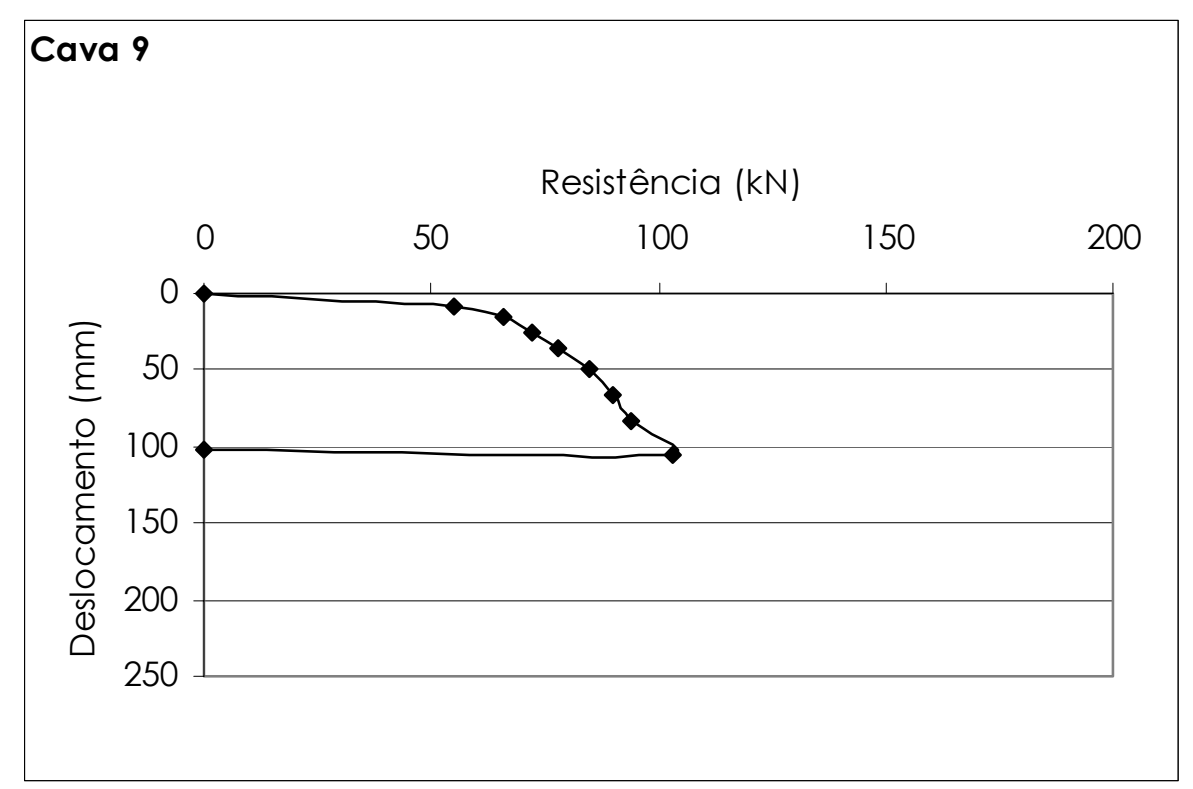

Figura 5.8 - Curva resistência mobilizada x deslocamento (cava 9, terreno não inundado)

\subsubsection{MEDIDA DOS DESLOCAMENTOS}

Além do monitoramento dinâmico, também foram feitas medidas de nega com uso de papel e lápis. Apesar dos resultados obtidos terem apresentado boa concordância com os deslocamentos permanentes fornecidos pelo PDA (Pile Driving Analyzer) - DFN, anteriormente à realização das análises CAPWAP® os sinais foram corrigidos para igualar o DFN à nega medida em campo.

Na Figura 5.9 foram plotados os valores das negas e DFN's de todos os ensaios dinâmicos realizados (cavas 1, 3, 4, 6, 7, 8 e 9). Os marcadores brancos representam dados obtidos em cavas ensaiadas com inundação prévia, e os pretos sem inundação. 


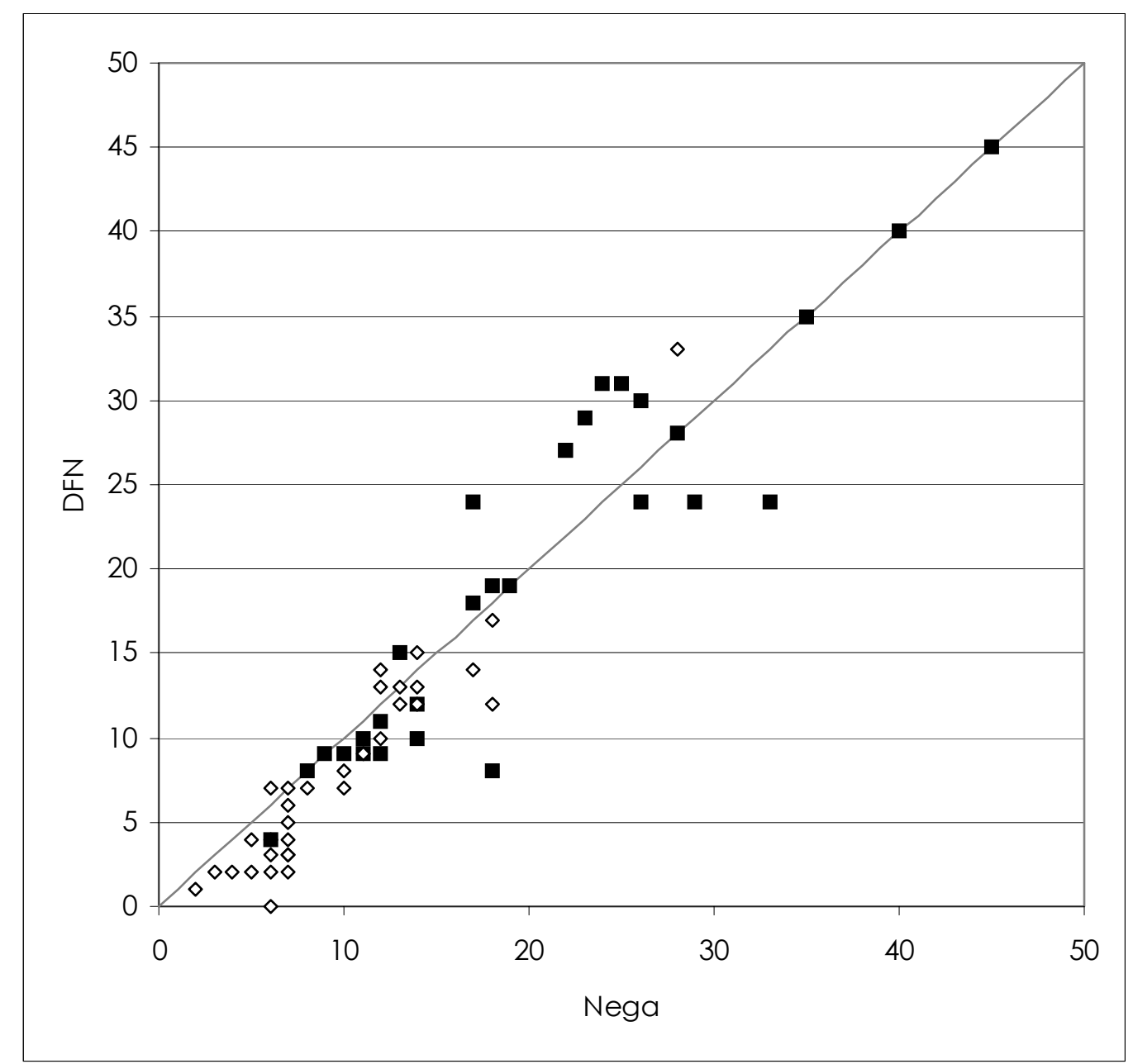

Figura 5.9 - Medidas de nega (papel e lápis) x deslocamentos permanentes (PDA)

\subsection{PROVAS DE CARGA ESTÁtICA EM PLACA}

As Figuras 5.10 a 5.13 mostram as curvas tensão-recalque obtidas nas quatro provas de carga estática rápidas das cavas 4, 7, 8 e 9. 


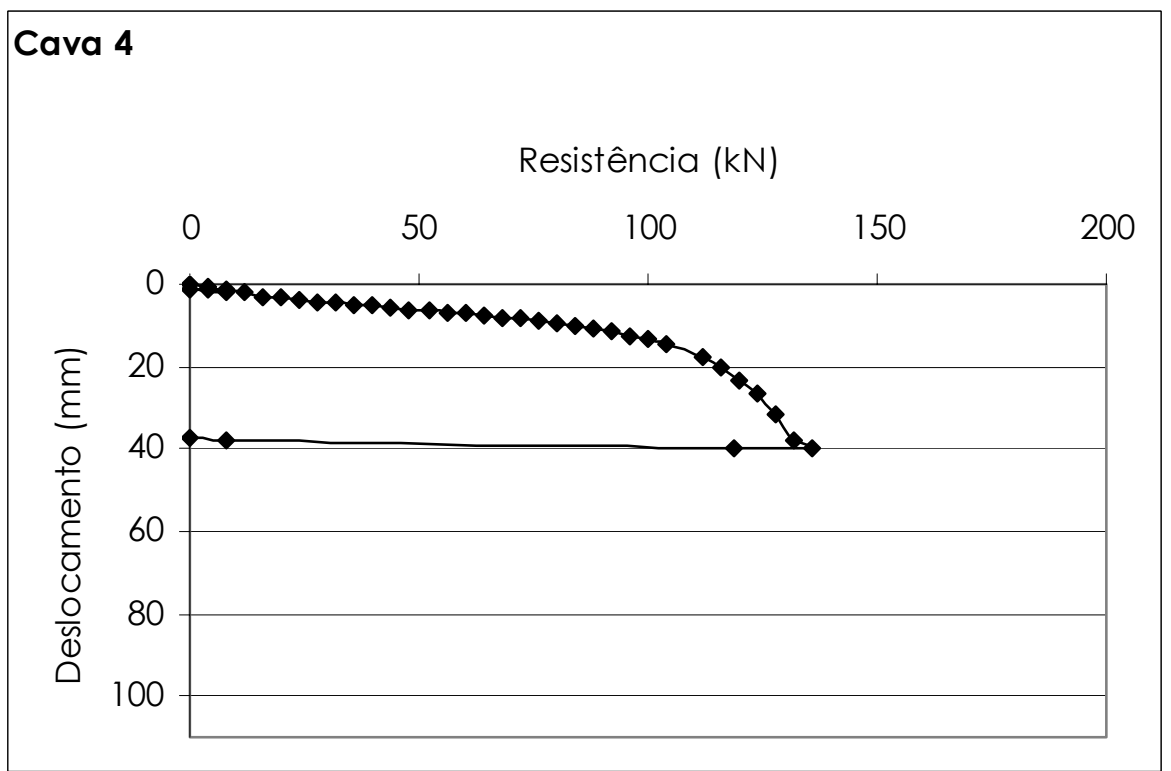

Figura 5.10 - Curva resistência x deslocamento (cava 4, terreno não inundado)

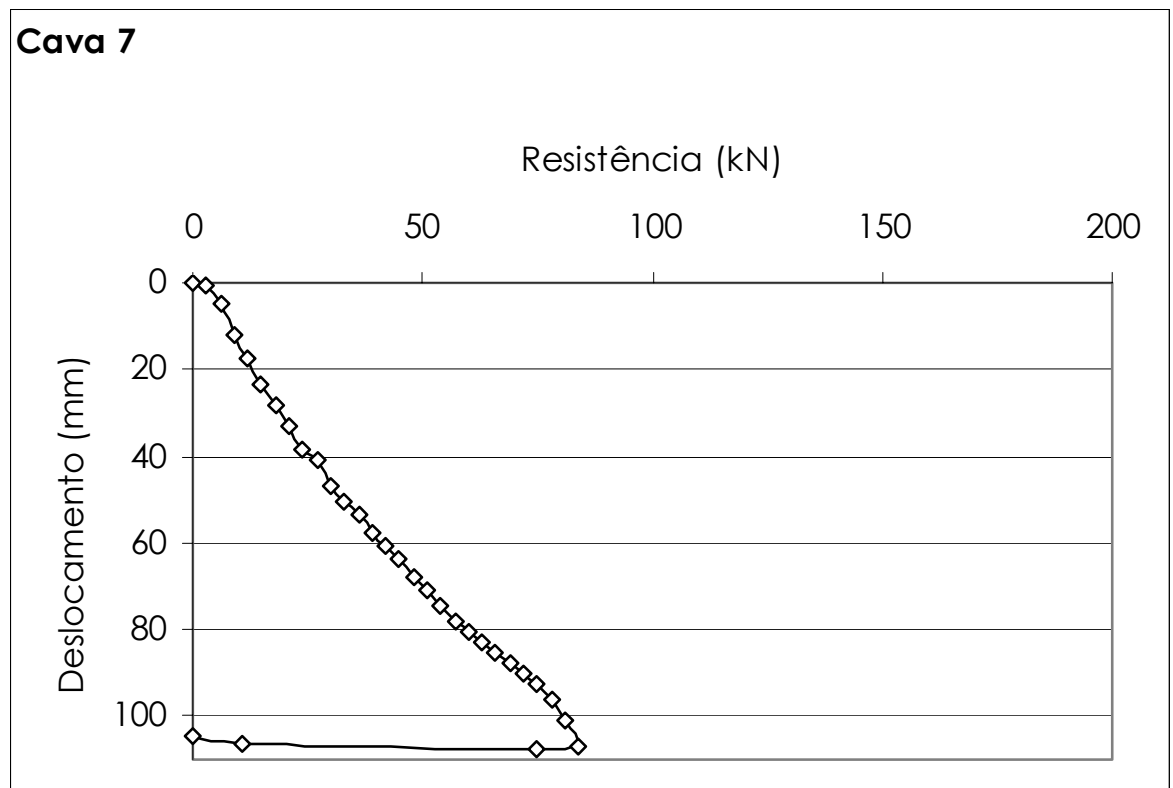

Figura 5.11 - Curva resistência $x$ deslocamento (cava 7, terreno inundado) 


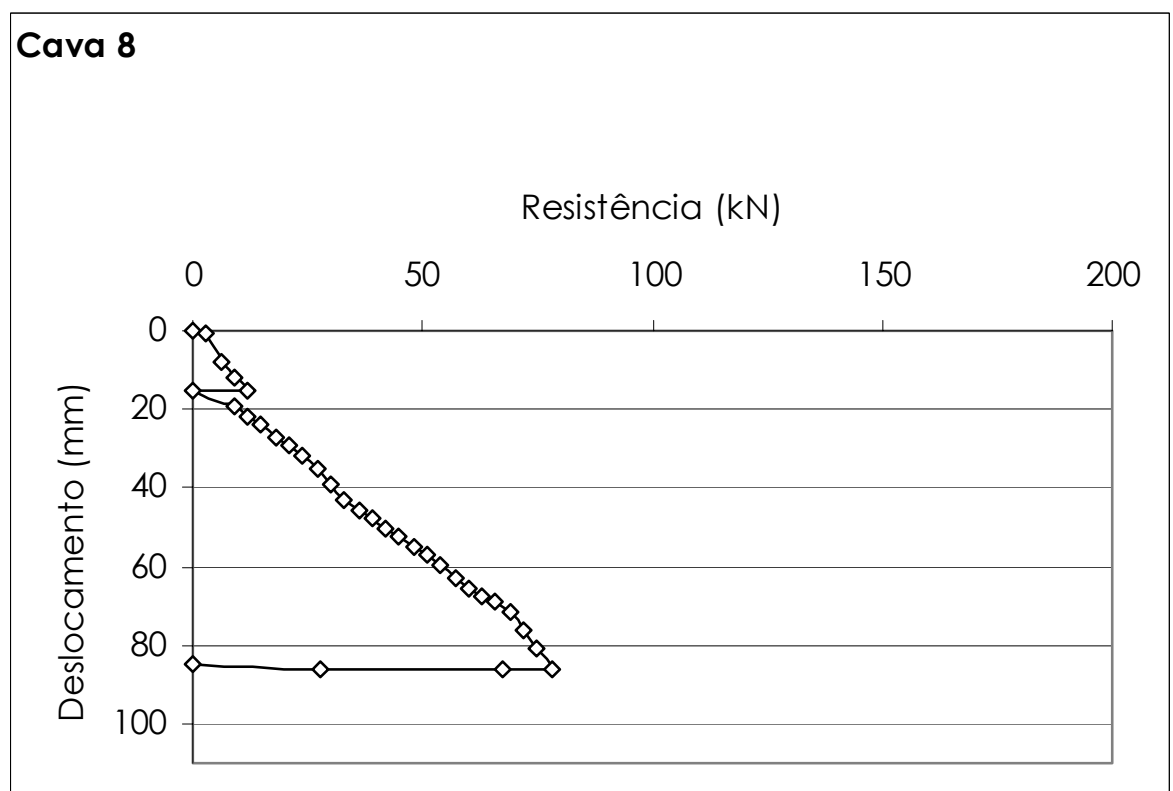

Figura 5.12 - Curva resistência x deslocamento (cava 8, terreno inundado)

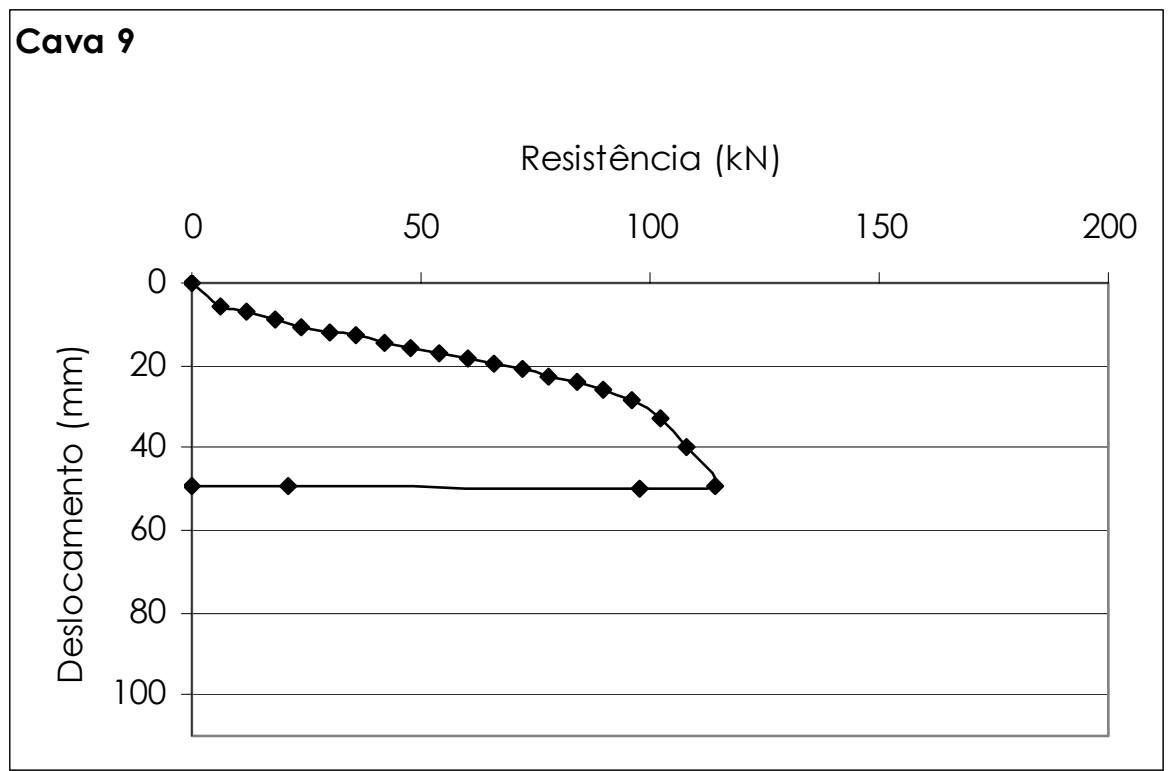

Figura 5.13 - Curva resistência x deslocamento (cava 9, terreno não inundado) 


\subsection{TENSIOMETRIA}

A Figura 5.14 mostra a variação da sucção matricial ao longo do tempo. A sucção foi registrada com o auxilio de tensiômetros instalados numa cava próxima às cavas de ensaio. As setas indicam os dias em que foram realizados ensaios em terreno não inundado. São apresentadas também as precipitações médias diárias fornecidas pela Embrapa Pecuária Sudeste (Fazenda Canchim, São Carlos-SP).

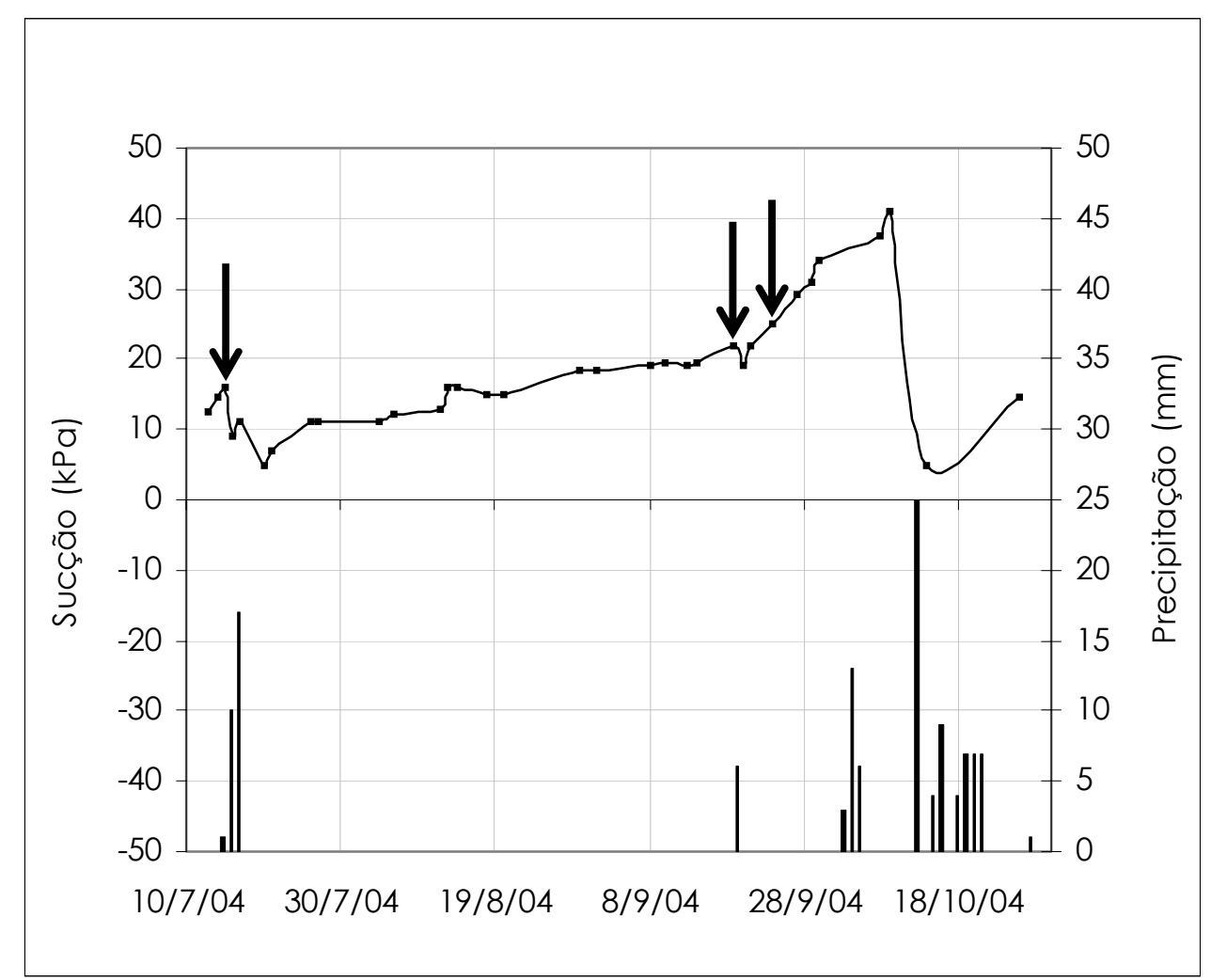

Figura 5.14 - Variação da sucção matricial e precipitação média diária ao longo do tempo 


\section{ANÁLISE DOS RESULTADOS}

\subsection{ANÁLISES CAPWAP®}

Todos os golpes de cada prova de carga dinâmica foram analisados com o auxílio do programa CAPWAP®. Houve, no geral, boa coincidência entre as curvas de força medida e calculada, que podem ser observadas no Apêndice B.

\subsubsection{MATCH QUALITY}

Metade das análises realizadas resultaram em match quality (MQ) entre 4 e 6\%. Estes valores podem ser considerados muito altos se comparados aos MQ's usualmente obtidos em análises de estacas cravadas, que ficam abaixo de 1\%. A Figura 6.1 mostra a distribuição dos valores de match quality.

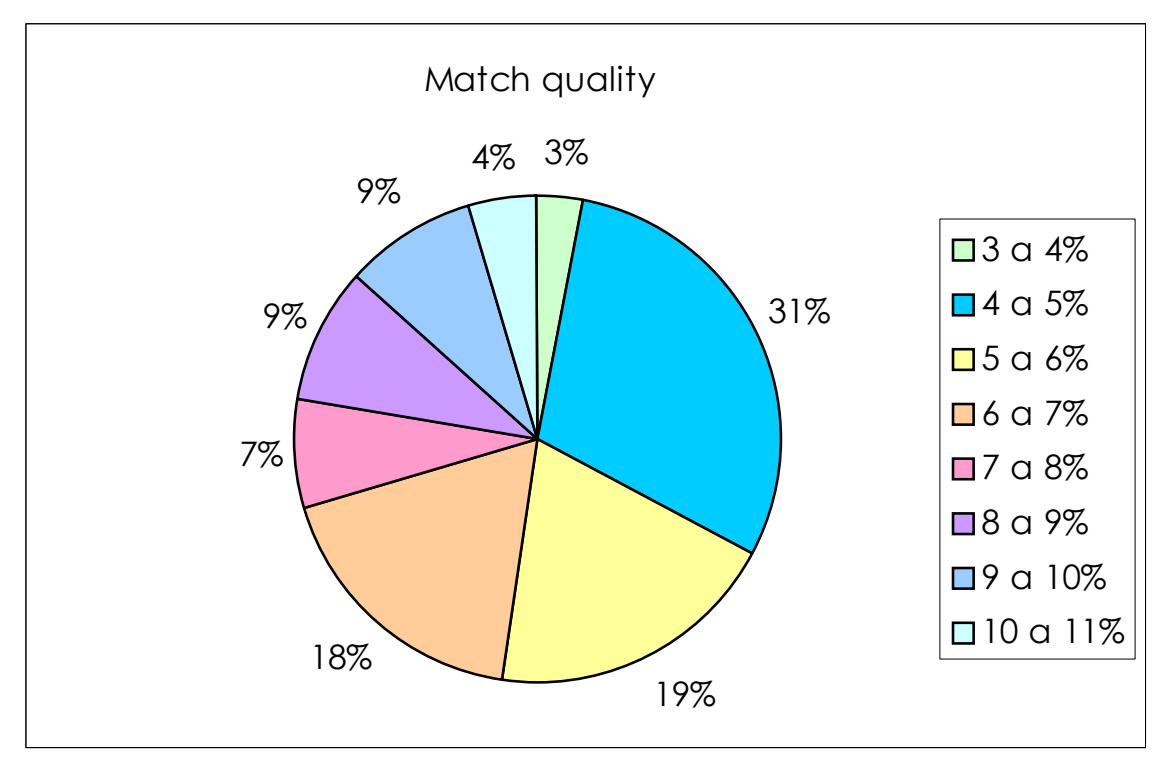

Figura 6.1 - Distribuição dos valores de match quality 
Em análises de tubulões submetidos a provas de carga dinâmica no mesmo campo experimental, em pesquisas anteriores, os MQ's variaram em torno de 4\% (Soares, 2002 e Campelo, 2000).

O elemento estrutural usado nesta, apesar de confeccionado em aço, não pareceu ser totalmente homogêneo. Para fixar os sensores foram feitos dois furos em posições diametralmente opostas, próximos ao topo do tubo, e um deles ofereceu maior resistência à furação, mesmo após a troca da broca por uma nova. Além disso, a peça ensaiada não pode ser perfeitamente modelada no programa CAPWAP®. Para obter MQ's aceitáveis foi necessário introduzir uma grande diminuição na impedância do segmento anterior à ponta da peça. Este fato pode ser talvez explicado por um movimento da flange em relação à placa (resultando numa diminuição da área de contato) no momento da aplicação de cada golpe, já que a impedância é proporcional à área da seção transversal (Equação 6.1). Talvez essas dificuldades expliquem os valores altos de $M Q$ 's.

$$
Z=\frac{E \cdot A}{c}
$$

Apesar dos bons resultados obtidos, o programa não foi desenvolvido para este tipo de análise, e travou constantemente. Com a resistência lateral igual a zero, quando o programa não travava, o valor de $M Q$ subia muito, ficando em torno de $2000 \%$, sem que houvesse nenhuma diminuição aparente na concordância entre as curvas de força medida e calculada. A solução encontrada (empiricamente) para que o programa não fechasse durante a análise, foi colocar um valor irrisório de resistência ao longo do fuste (no caso, $0,001 \mathrm{kN})$.

Nas cavas 1 e 3, para as quais foram adotados os maiores incrementos de energia, notou-se a necessidade de não somente analisar todos os golpes de cada série, mas também ter um número total de golpes suficiente para uma boa definição da curva 
resistência mobilizada $x$ deslocamento. Os incrementos de energia da prova de carga dinâmica devem ser programados de forma que se tenha um número adequado de pontos, para que se tenha uma boa definição da curva e seja possível observar alguma discrepância.

Houve casos em que golpes correspondentes a energias maiores forneceram resultados de resistências inferiores aos de energias maiores, o que também foi observado por Campelo (2000).

\subsection{COMPARAÇÃo ENTRE OS MÉTOdOS CASE E CAPWAP ${ }^{\circledR}$}

Além das análises CAPWAP®, as forças resistentes dos ensaios dinâmicos também foram calculadas através do método simplificado CASE a partir de um $J_{c}$ (constante de amortecimento) estimado. Atualmente se sabe que $J_{c}$ varia a cada golpe, pois depende do nível de energia empregado e não só do tipo de solo, como se acreditava anteriormente. A obtenção da capacidade de carga através do método CASE foi feita para que fosse possível verificar a capacidade de carga ainda em campo, podendo cada elemento ensaiado ser cravado até que fosse atingida a capacidade de carga requerida em um projeto (válido para o tipo de solo ensaiado, no qual ocorre aumento da resistência com a cravação).

Para os ensaios efetuados em cavas não inundadas $(3,4,6$ e 9) o Jc adotado foi 0,25, escolhido a partir do tipo de solo ensaiado (areia argilosa). Esse mesmo solo quando inundado apresentou comportamento diferente do esperado para um solo arenoso, durante a realização das provas de carga dinâmica. Ao sacar o conjunto tubo-placa 
observava-se uma espessa camada de solo aderida à placa, o que normalmente acontece em solos com alto teor de argila. Em prova de carga dinâmica realizada por Campelo, 2000, em tubulão, no mesmo terreno, previamente inundado, já havia sido observado que a curva resistência mobilizada $\mathrm{x}$ deslocamento apresentava ruptura nítida, o que também é esperado para solos argilosos. Em provas de carga estática realizadas em placas, sapatas e tubulões, no mesmo local, também com terreno inundado, as curvas carga-recalque não apresentam ruptura nítida. Elas são do tipo aberta, assim como as curvas dos ensaios realizados em terreno não inundado, porém com resistências menores. A vibração provocada pelos golpes do bate-estaca deve exercer algum tipo de influência dinâmica neste tipo de solo, quando inundado, levando-o a apresentar um comportamento similar ao de solos argilosos. Por isso, para os ensaios em cavas inundadas (1, 6 - reensaio, 7 e 8) foi adotado Jc igual a 0,40, o qual é indicado para solos mais finos.

As Figuras 6.2 a 6.9 apresentam as curvas força resistente estática, encontrada através dos métodos CASE e CAPWAP®, plotada contra o recalque (DMX) para cada cava. Houve boa concordância entre as forças encontradas pelos dois métodos para a maioria dos ensaios realizados. 


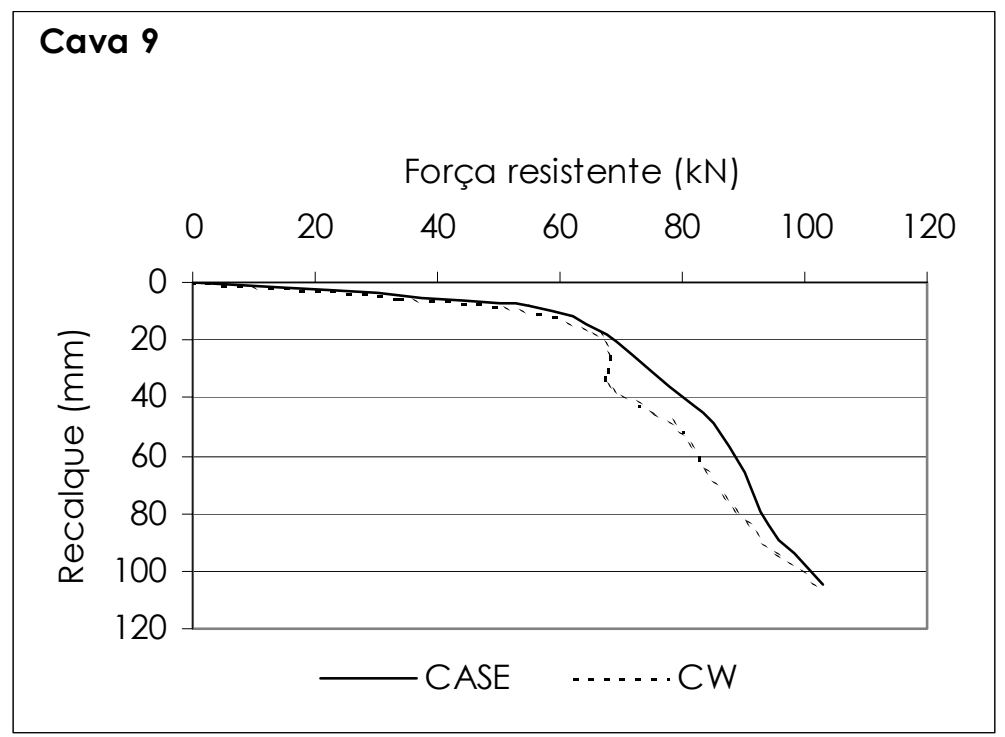

Figura 6.2 - Curvas força resistente x recalque (cava 9, não inundada) dos métodos CASE e CAPWAP®

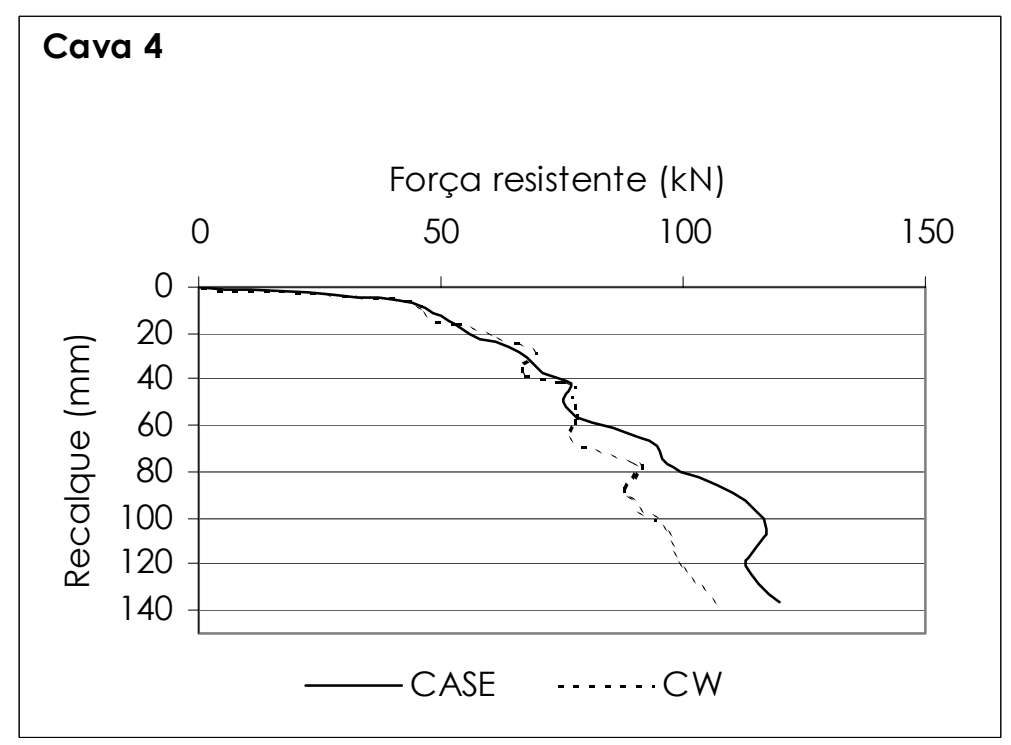

Figura 6.3 - Curvas força resistente x recalque (cava 4, não inundada) dos métodos CASE e CAPWAP® 


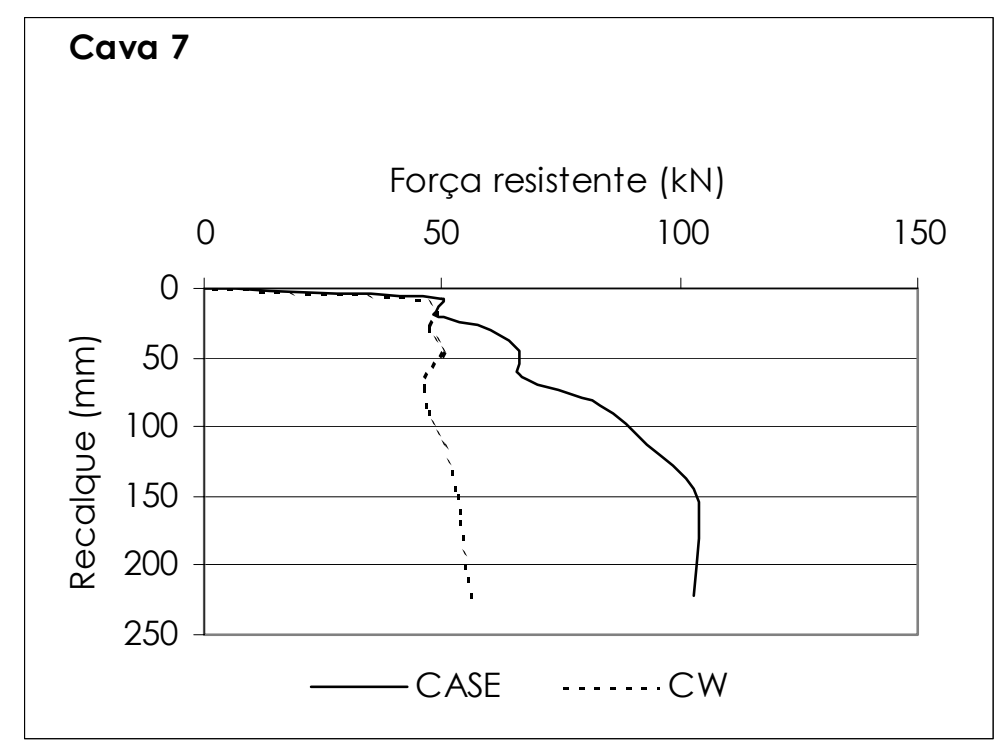

Figura 6.4 - Curvas força resistente x recalque (cava 7, inundada) dos métodos CASE e CAPWAP®

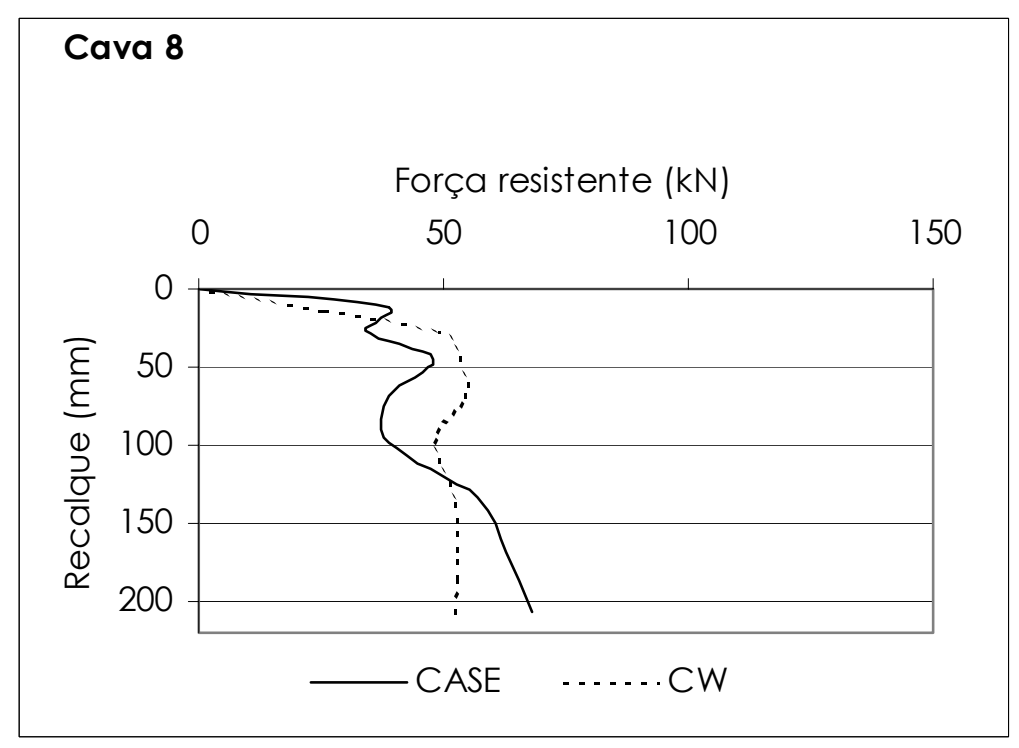

Figura 6.5 - Curvas força resistente x recalque (cava 8, inundada) dos métodos CASE e CAPWAP® 


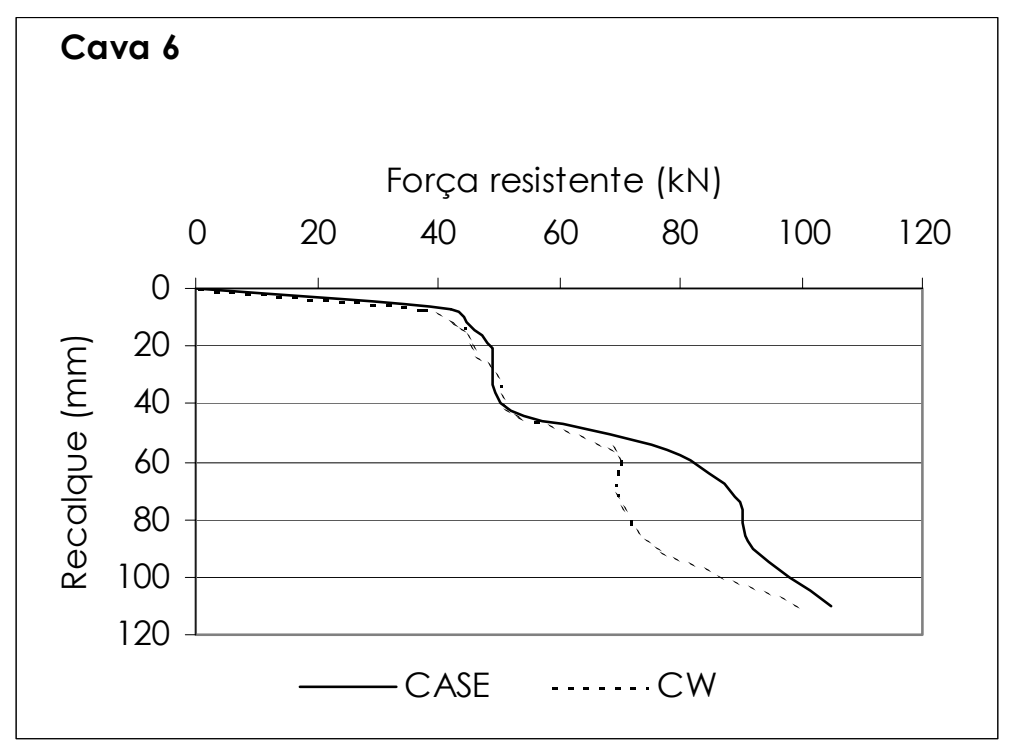

Figura 6.6 - Curvas força resistente x recalque (cava 6, não inundada) dos métodos CASE e CAPWAP ${ }^{\circledR}$

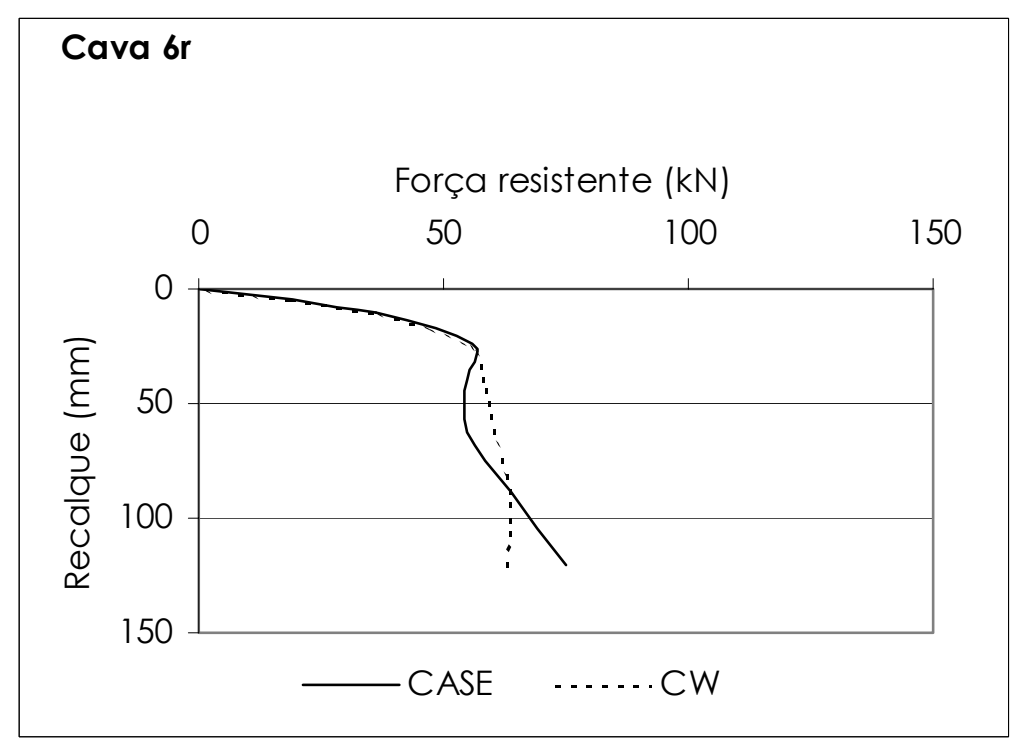

Figura 6.7 - Curvas força resistente x recalque (cava 6, inundada) dos métodos CASE e CAPWAP® 


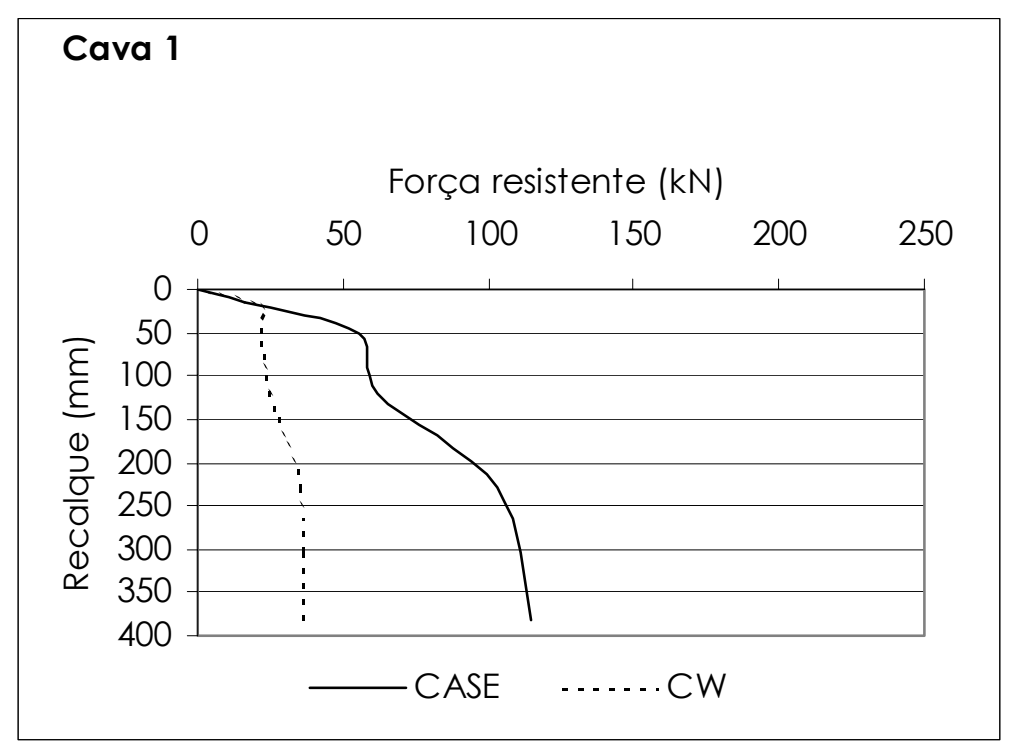

Figura 6.8 - Curvas força resistente x recalque (cava 1, inundada) dos métodos CASE e CAPWAP®

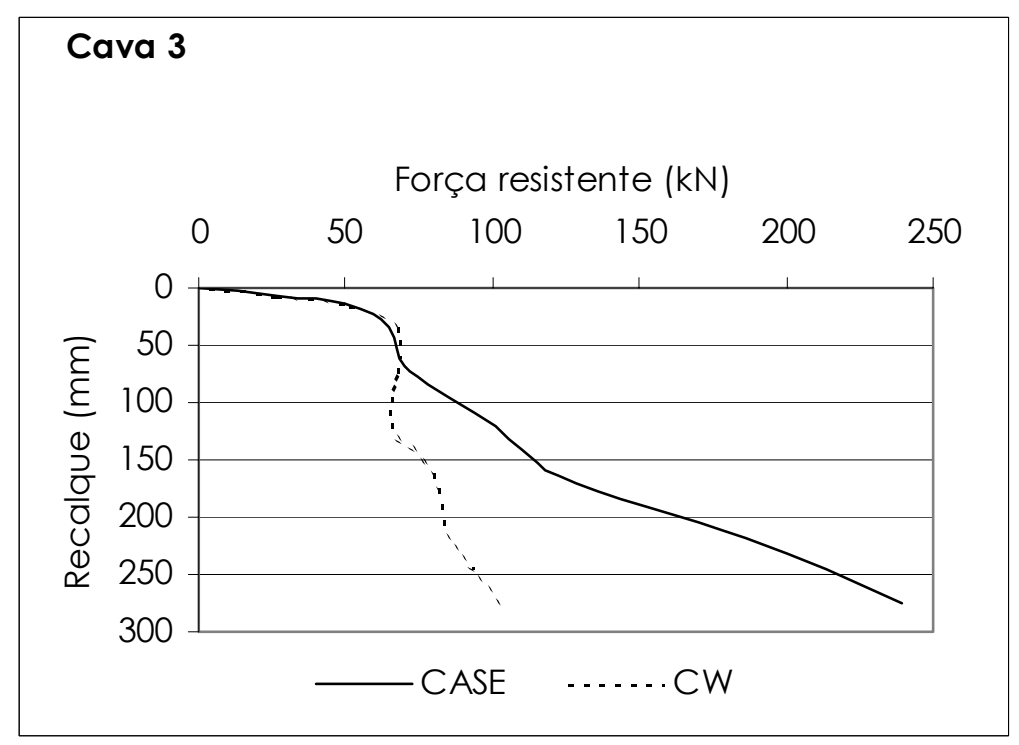

Figura 6.9 - Curvas força resistente x recalque (cava 3, não inundada) dos métodos CASE e CAPWAP®

A Tabela 6.1 mostra os valores de energia máxima aplicada ao sistema, fornecido pelo PDA, acumulado para todos os golpes, por cava, em ordem crescente, e o desvio padrão médio das curvas. Comparando-se os valores de energia com os de desvio, é 
possível observar que, no geral, quanto maior a energia empregada, maior a diferença entre os métodos CASE e CAPWAP®. O mesmo pode ser observado na Figura 6.10, que apresenta todos os gráficos das Figuras 6.2 a 6.9 em ordem crescente de energia máxima acumulada aplicada ao sistema tubo-placa-solo durante as provas de carga dinâmica. Isto confirma a influência do nível de energia empregado no valor de Jc.

Tabela 6.1 - Energia máxima aplicada ao sistema e desvio padrão médio entre os métodos CASE e CAPWAP® para cada cava

\begin{tabular}{|c|c|c|}
\hline Cava & EMX (kN.m) & Omédio (\%) \\
\hline 6 & 8,8 & 6 \\
\hline 9 & 9,9 & 4 \\
\hline $6 r$ & 10,0 & 4 \\
\hline 4 & 13,5 & 6 \\
\hline 8 & 14,2 & 18 \\
\hline 7 & 18,5 & 23 \\
\hline 1 & 22,3 & 41 \\
\hline 3 & 32,4 & 19 \\
\hline
\end{tabular}




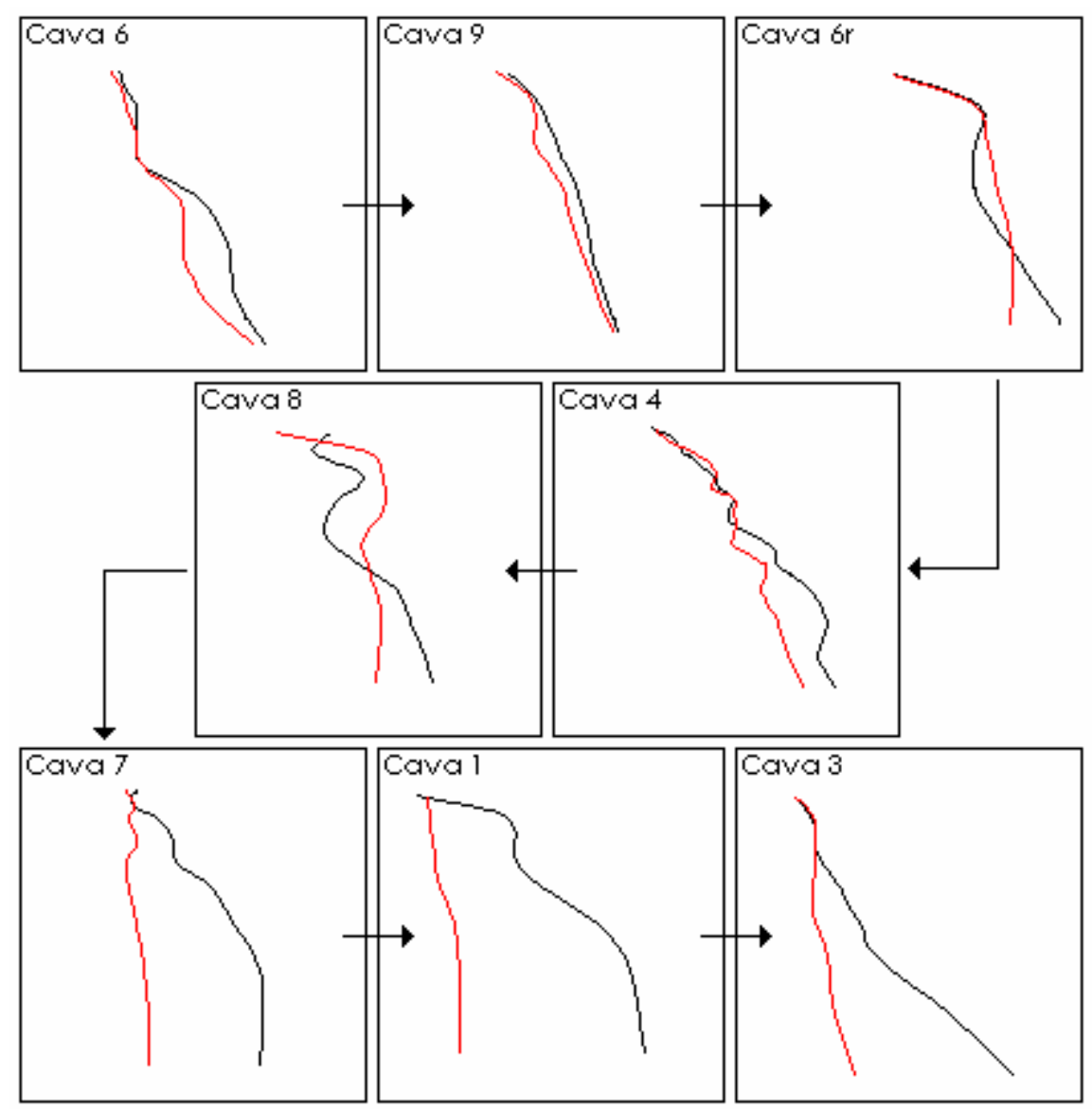

Figura 6.10 - Gráficos das figuras 6.2 a 6.9 em ordem crescente de energia (linha vermelha $=$ CAPWAP ${ }^{\circ}$, linha preta=CASE)

\subsection{COMPARAÇÃo ENTRE PROVAS DE CARGA DINÂMICA E ESTÁTICA EM PLACA}

Nas Figuras 6.11 a 6.14 são mostradas as curvas tensão $x$ recalque obtidas nas sucessivas provas de carga realizadas em quatro cavas: 1) provas de carga estática de Costa (1999), 2) provas de carga dinâmica e 3) provas de carga estática realizadas nesta pesquisa. Os três gráficos exibem o recalque acumulado conforme a seqüência de execução. Para as provas de carga dinâmica são exibidas as forças resistentes encontradas através de análises CAPWAP® divididas pela área da placa, obtendo-se assim as tensões 
resistentes; os recalques apresentados correspondem ao DMX (deslocamento máximo) fornecido pelo PDA. Nas cavas 4 e 9 os ensaios foram realizados em terreno não inundado, e nas cavas 7 e 8 em terreno inundado.

As três curvas tensão $\mathrm{x}$ recalque de cada uma das Figuras 6.11 a 6.14 apresentam uma relação praticamente linear entre o recalque e a correspondente carga aplicada, na fase de deformações plásticas, e descarregamento praticamente horizontal. Esse tipo de curva pode ser observado em outras provas de carga realizadas no mesmo local, em placa e em tubulão.

Assim como no trabalho de Benvenutti (2001), observa-se que a parte final de cada curva carga $\mathrm{x}$ recalque dos sucessivos ensaios de uma mesma cava constitui uma espécie de trecho reto único. Assim, desconsiderando o descarregamento e o carregamento subseqüente, até atingir a tensão máxima do ensaio anterior, pode-se obter uma curva única, com razoável coerência. Essa curva, formada pela união das três curvas das três provas de carga (estática, dinâmica, estática) realizados em cada cava, é do tipo aberta, típica de todos os ensaios de placa realizados nesse local. A continuidade entre os trechos finais das curvas dos sucessivos ensaios realizados em cada cava é mais bem caracterizada nos casos em que não houve inundação prévia do terreno, cavas 9 e 4 (Figuras 6.11 e 6.12).

As curvas obtidas com as provas de carga dinâmica "encaixam" razoavelmente bem entre as duas provas de carga estática. Esta compatibilidade entre os ensaios indica a viabilidade da prova de carga dinâmica em placa. 


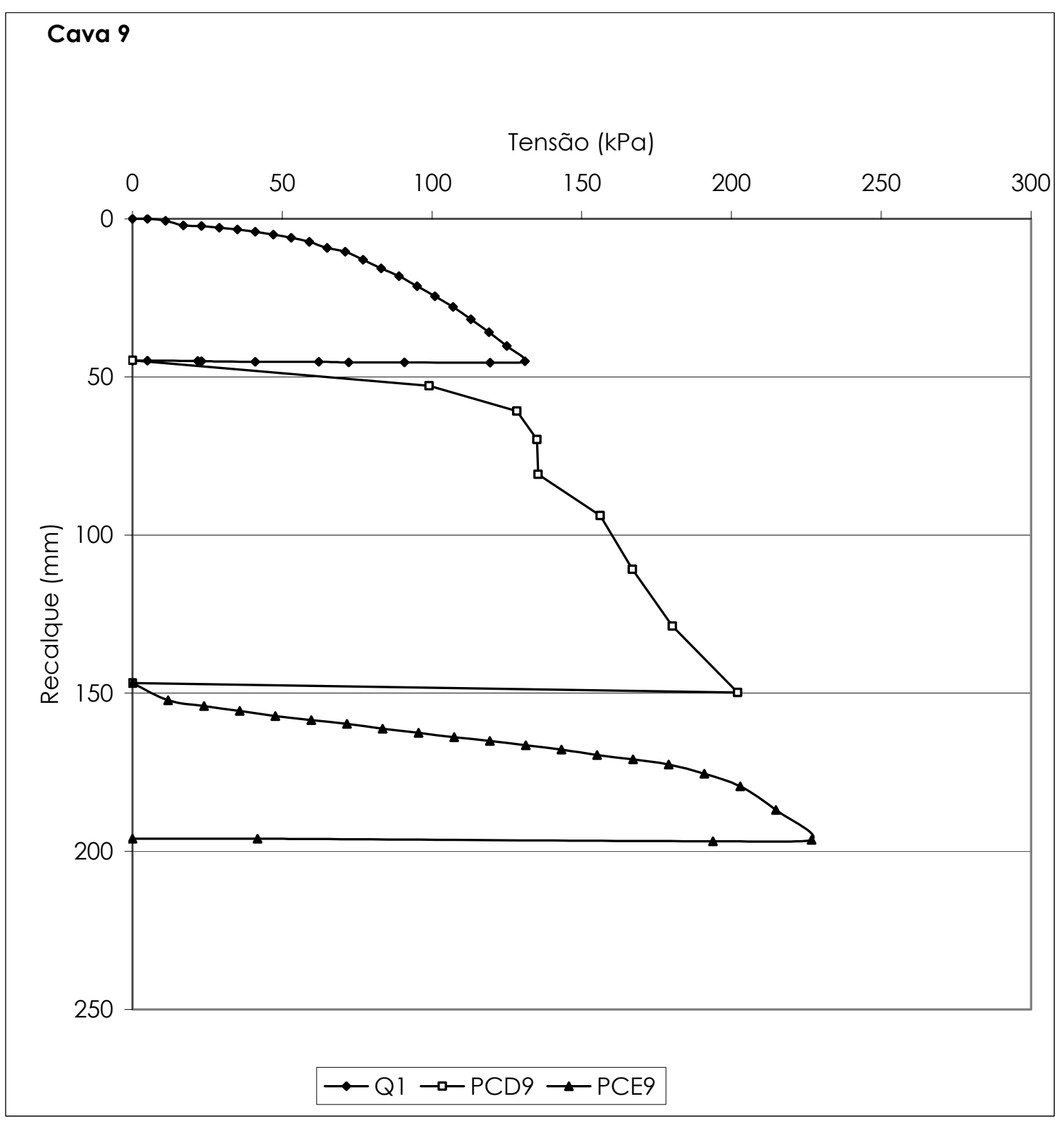

Figura 6.11 - Curvas tensão x recalque de três ensaios consecutivos: um dinâmico entre dois estáticos (cava 9, terreno não inundado) 


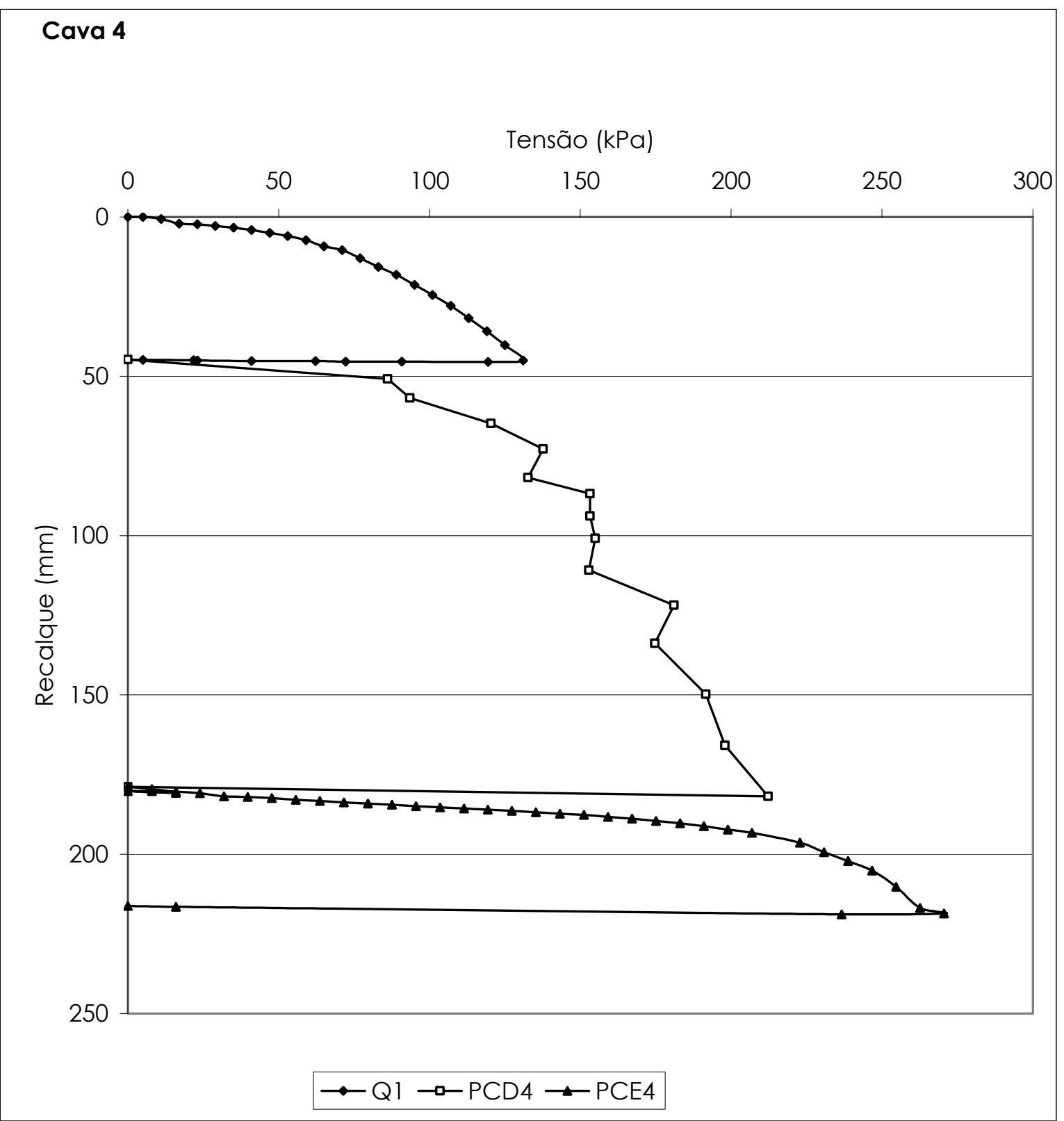

Figura 6.12 - Curvas tensão x recalque de três ensaios consecutivos: um dinâmico entre dois estáticos (cava 4, terreno não inundado) 


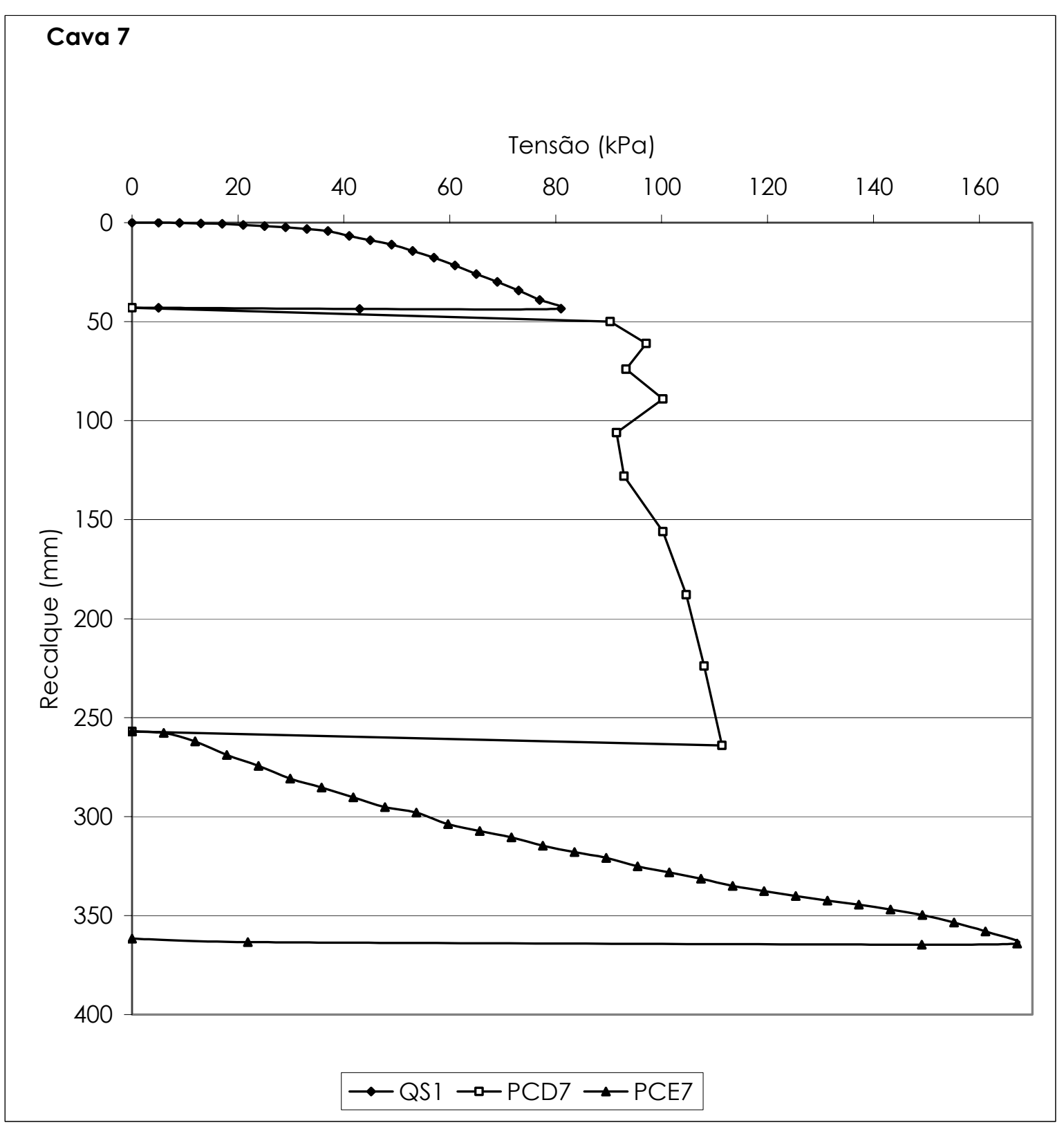

Figura 6.13 - Curvas tensão x recalque de três ensaios consecutivos: um dinâmico entre dois estáticos (cava 7, terreno inundado) 


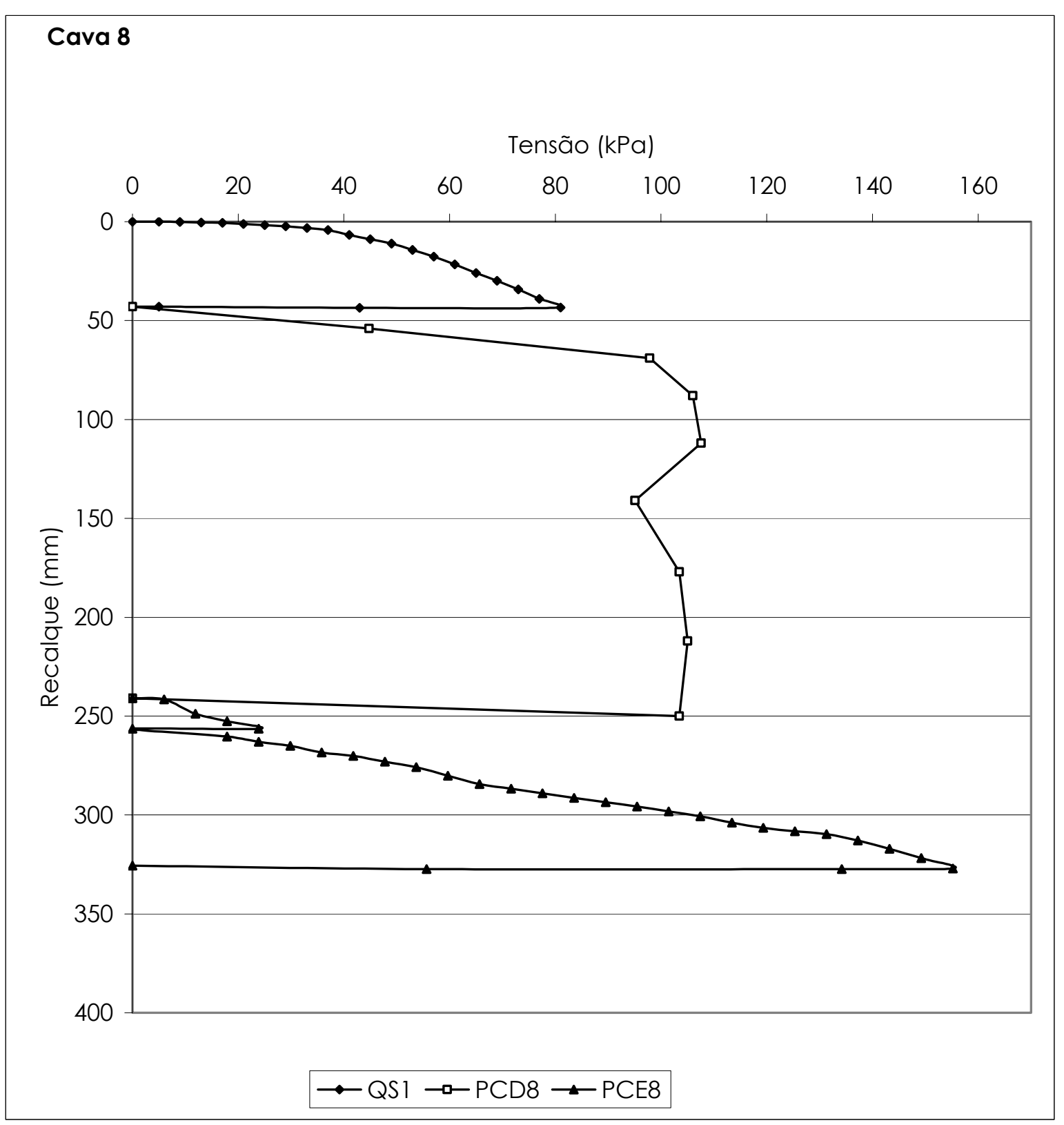

Figura 6.14 - Curvas tensão x recalque de três ensaios consecutivos: um dinâmico entre dois estáticos (cava 8, terreno inundado) 


\subsection{CAPACIDADE DE CARGA}

Na análise da capacidade de carga serão consideradas as influências do embutimento e da sucção matricial.

\subsubsection{INFLUÊNCIA DO EMBUTIMENTO}

\section{Cavas 4, 7, 8 e 9}

Na análise da influência do embutimento da placa na capacidade de carga, para as cavas 4, 7, 8 e 9, será considerado que as três curvas tensão x recalque de cada cava (Figuras 6.11 a 6.14) formam uma curva única.

Como a curva "aberta" não caracteriza ruptura nítida do sistema, pois qualquer acréscimo de tensão causa aumento da rigidez do solo, nem permite que se aplique o modelo de ruptura física (Van der Veen, por exemplo) é necessário adotar um critério de ruptura convencional na interpretação dos sucessivos ensaios.

Foi adotado o critério pelo qual a capacidade de carga corresponde a um recalque igual a $25 \mathrm{~mm}$. Para verificar o aumento da capacidade de carga com a cravação da placa foi adotada a solução usada por Benvenutti (2001) na interpretação de sucessivas provas de carga estática em dois tubulões no campo experimental da USP/São Carlos. Foram arbitrados comprimentos de embutimento da placa, a partir do fundo da cava, e obedecendo ao critério de ruptura convencional adotado, a capacidade de carga foi considerada como a tensão que provoca um recalque "adicional" de $25 \mathrm{~mm}$.

As provas de carga em terreno inundado atingiram recalques maiores que as em terreno não inundado, por isso foram adotados comprimentos de embutimento diferentes para cada situação. Para as cavas não inundadas (9 e 4) os embutimentos adotados foram 
0, 50, 100 e $150 \mathrm{~mm}$, para os quais os valores de capacidade de carga são aqueles que provocam recalques de 25, 75, 125 e $175 \mathrm{~mm}$, respectivamente. Para as cavas inundadas (7 e 8), os embutimentos adotados foram 0, 100, 200, e $300 \mathrm{~mm}$, para os quais os valores de capacidade de carga são aqueles que provocam recalques de 25, 125, 225 e 325 mm, respectivamente.

Nas Tabelas 6.2 a 6.5 são apresentados os valores de capacidade de carga para cada cava, e a sucção matricial no momento de cada ensaio.

Tabela 6.2 - Valores de capacidade de carga e sucção matricial (cava 9, terreno não inundado)

\begin{tabular}{|c|c|c|c|}
\hline $\begin{array}{c}\text { Embutimento } \\
(\mathrm{mm})\end{array}$ & Ensaio & $\begin{array}{c}\sigma_{r} \\
(\mathrm{kPa})\end{array}$ & $\begin{array}{c}\text { SUcção } \\
(\mathrm{kPa})\end{array}$ \\
\hline 0 & Q1 & 102 & 15 \\
\hline 50 & PCD9 & 135 & 16 \\
\hline 100 & PCD9 & 185 & 16 \\
\hline 150 & PCE9 & 209 & 25 \\
\hline
\end{tabular}

Tabela 6.3 - Valores de capacidade de carga e sucção matricial (cava 4, terreno não inundado)

\begin{tabular}{|c|c|c|c|}
\hline $\begin{array}{c}\text { Embutimento } \\
(\mathrm{mm})\end{array}$ & Ensaio & $\begin{array}{c}\text { or } \\
(\mathrm{kPa})\end{array}$ & $\begin{array}{c}\text { Sucção } \\
(\mathrm{kPa})\end{array}$ \\
\hline 0 & Q1 & 102 & 15 \\
\hline 50 & PCD4 & 153 & 16 \\
\hline 100 & PCD4 & 202 & 16 \\
\hline 150 & PCE4 & 273 & 22 \\
\hline
\end{tabular}


Tabela 6.4 - Valores de capacidade de carga e sucção matricial (cava 7, terreno inundado)

\begin{tabular}{|c|c|c|c|}
\hline $\begin{array}{c}\text { Embutimento } \\
(\mathrm{mm})\end{array}$ & Ensaio & $\begin{array}{c}\sigma_{r} \\
(\mathrm{kPa})\end{array}$ & $\begin{array}{c}\text { SUcção } \\
(\mathrm{kPa})\end{array}$ \\
\hline 0 & QS1 & 64 & $\cong 0$ \\
\hline 100 & PCD7 & 98 & $\cong 0$ \\
\hline 200 & PCD7 & 112 & $\cong 0$ \\
\hline 300 & PCE7 & 167 & $\cong 0$ \\
\hline
\end{tabular}

Tabela 6.5 - Valores de capacidade de carga e sucção matricial (cava 8, terreno inundado)

\begin{tabular}{|c|c|c|c|}
\hline $\begin{array}{c}\text { Embutimento } \\
(\mathrm{mm})\end{array}$ & Ensaio & $\begin{array}{c}\text { or } \\
(\mathrm{kPa})\end{array}$ & $\begin{array}{c}\text { Sucção } \\
(\mathrm{kPa})\end{array}$ \\
\hline 0 & QS1 & 64 & $\cong 0$ \\
\hline 100 & PCD8 & 103 & $\cong 0$ \\
\hline 200 & PCD8 & 123 & $\cong 0$ \\
\hline 300 & PCE8 & 177 & $\cong 0$ \\
\hline
\end{tabular}

Comparando-se a resistência obtida para um embutimento de $150 \mathrm{~mm}$ com a obtida sem considerar o embutimento, o aumento da capacidade de carga foi de $105 \%$ na cava 9 e $168 \%$ na cava 4. Nas cavas inundadas, comparando-se a resistência obtida para um embutimento de $300 \mathrm{~mm}$ com a obtida sem considerar o embutimento, o aumento foi de $161 \%$ na cava 7 e $177 \%$ na cava 8.

Na Figura 6.15 observa-se que a relação entre a capacidade de carga e o embutimento é linear e crescente tanto para as cavas inundadas quanto para as não inundadas. 


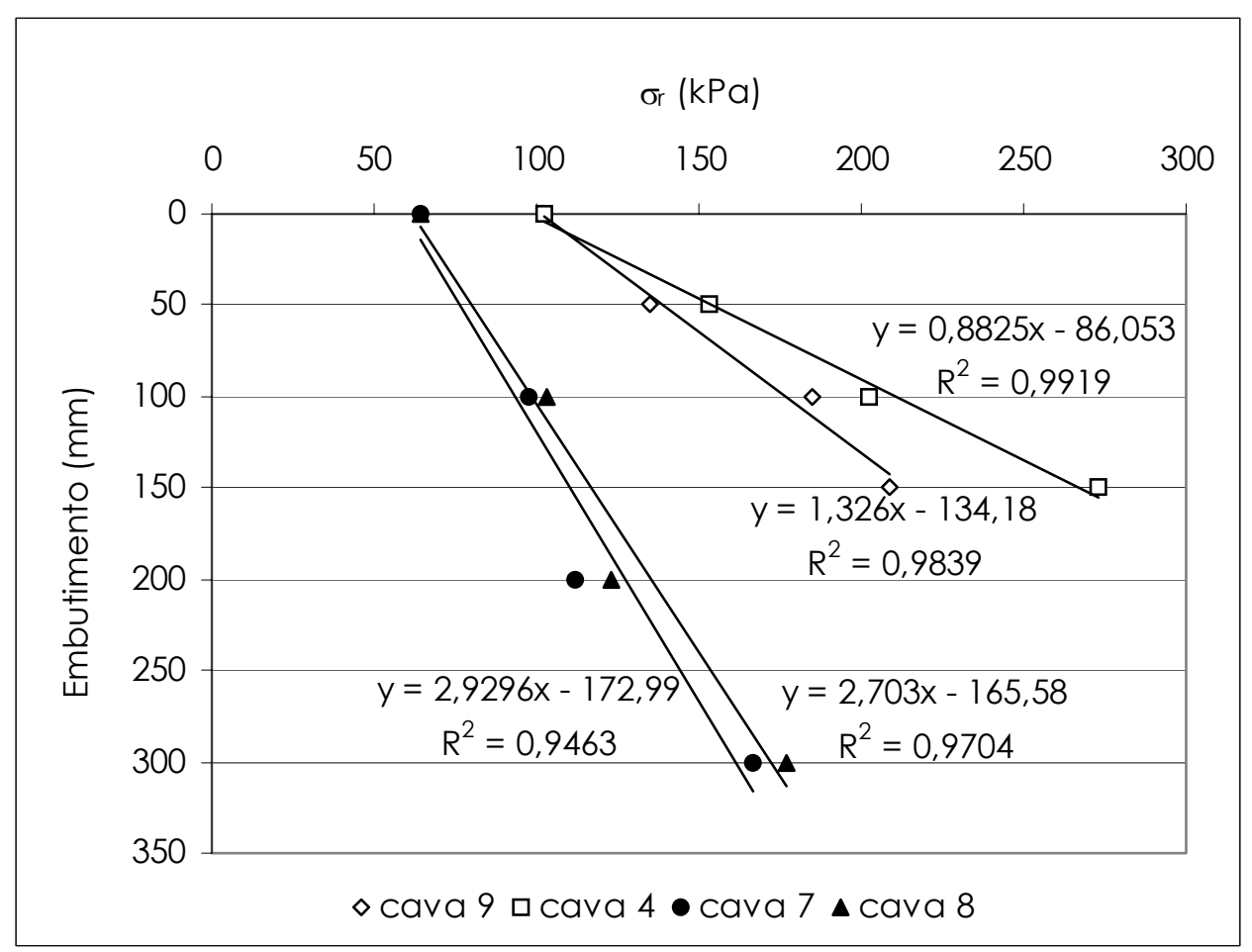

Figura 6.15 - Embutimento x capacidade de carga (os marcadores pretos representam ensaios em cavas não inundadas e os marcadores brancos, inundadas)

A partir dos ajustes lineares (Figura 6.15) foi possível calcular a taxa de aumento da capacidade de carga em função do embutimento, para cada cava. Os valores obtidos encontram-se na Tabela 6.6.

Tabela 6.6 - Taxas de aumento da capacidade de carga em função da cravação para as cavas $9,4,7$ e 8

\begin{tabular}{|c|c|c|}
\hline Cava & $\begin{array}{c}\text { Pré- } \\
\text { inundação }\end{array}$ & $\begin{array}{c}\text { Taxa } \\
(\mathrm{kPa} / \mathrm{mm})\end{array}$ \\
\hline 9 & não & 0,75 \\
\hline 4 & não & 1,13 \\
\hline 7 & $\operatorname{sim}$ & 0,34 \\
\hline 8 & sim & 0,37 \\
\hline
\end{tabular}

Essa taxa de crescimento nas cavas inundadas é, em média, $61 \%$ menor que nas cavas não inundadas. 


\section{Cavas 1 e 3}

Nas cavas 1 e 3, foram realizadas somente provas de carga dinâmica, com incrementos de energia maiores, para embutir a placa, através da cravação, o equivalente a $30 \%$ do seu diâmetro.

Na cava 1, o ensaio foi realizado com inundação prévia do terreno e na cava 3 sem inundação. A Figura 6.16 mostra as curvas tensão $x$ recalque dos dois ensaios.

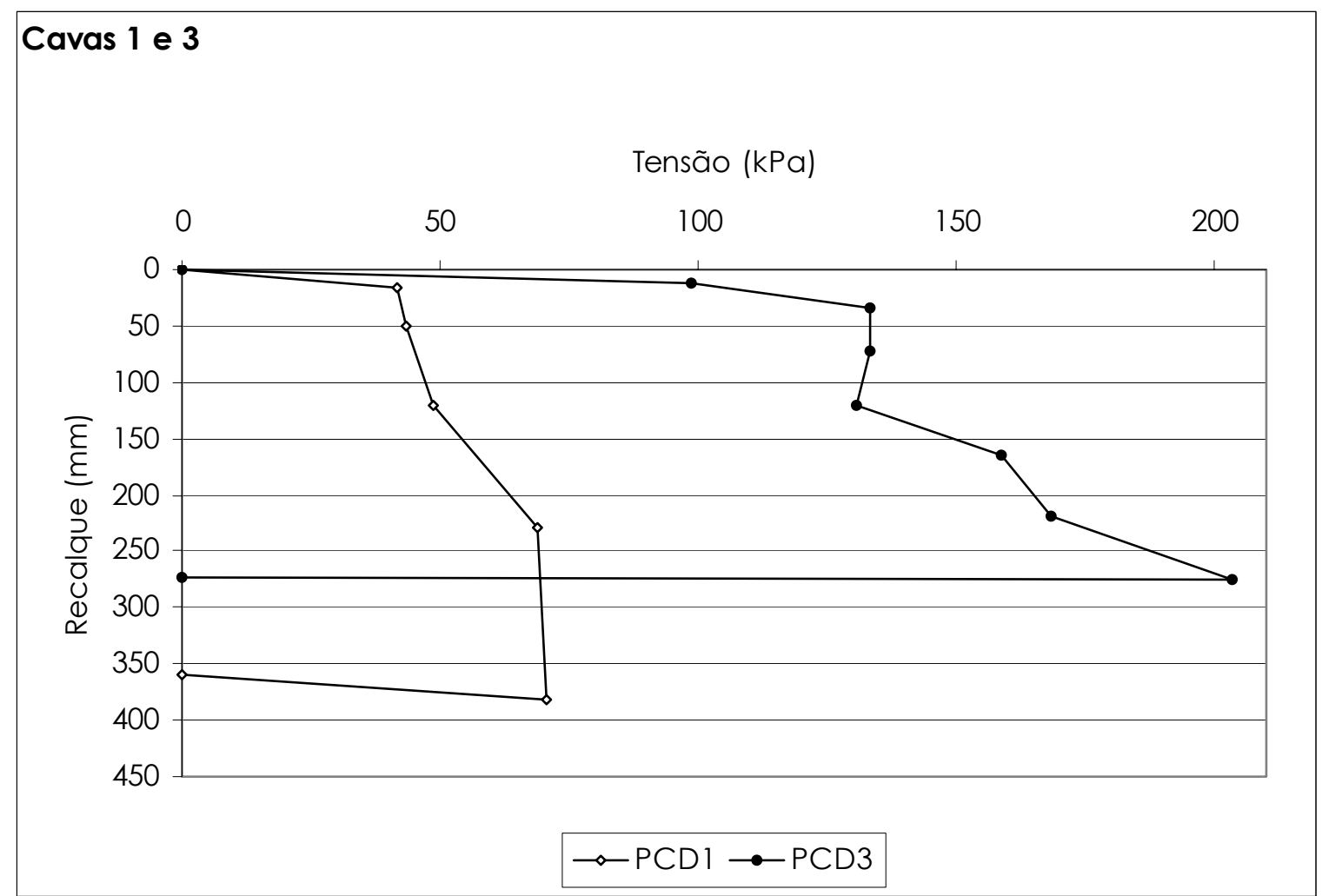

Figura 6.16 - Curvas tensão-recalque (provas de carga dinâmica, cavas 1 e 3)

Para observar os efeitos da cravação do sistema placa-solo, calculou-se a capacidade de carga para os embutimentos equivalentes a 0, 10, 20 e 30\% do diâmetro da placa, ou seja, 0, 80, 160 e $240 \mathrm{~mm}$. Assim como para as cavas 4, 7, 8 e 9, foi adotado o critério de ruptura convencional pelo qual a capacidade de carga corresponde a um recalque igual a $25 \mathrm{~mm}$, a partir de cada embutimento (recalques de 25, 105, 185 e $265 \mathrm{~mm}$, respectivamente). A tabela 6.7 mostra o valor da capacidade de carga para cada 
embutimento.

Tabela 6.7 - Capacidade de carga considerando a placa sem embutimento, com embutimento de 10\%, 20\% e 30\% do diâmetro, e sucção matricial no momento dos ensaios

\begin{tabular}{|c|c|c|c|}
\hline \multicolumn{2}{|c|}{ Embutimento } & Cava 1 & Cava 3 \\
or & $(\mathrm{mm})$ & $\sigma_{r}$ \\
\hline 0 & 0 & 42 & 119 \\
\hline 10 & 80 & 48 & 132 \\
\hline 20 & 160 & 60 & 163 \\
\hline 30 & 240 & 69 & 197 \\
\hline \multicolumn{2}{|l|}{ Sucção (kPa) } & 16 & $\cong 0$ \\
\hline
\end{tabular}

Tanto para a cava 1 quanto para a 3, o embutimento de 30\% do diâmetro da placa conferiu um aumento aproximado de $65 \%$ da capacidade de carga em relação àquela sem considerar o embutimento.

Apesar de terem apresentado o mesmo crescimento percentual da capacidade de carga, observa-se pela Figura 6.17 que o embutimento causa aumento maior de resistência no ensaio realizado em terreno não inundado (reta com maior inclinação).

A partir dos ajustes lineares (Figura 6.17) foi possível calcular a taxa de aumento da capacidade de carga em função do embutimento para cada cava. Os valores obtidos encontram-se na Tabela 6.8. 


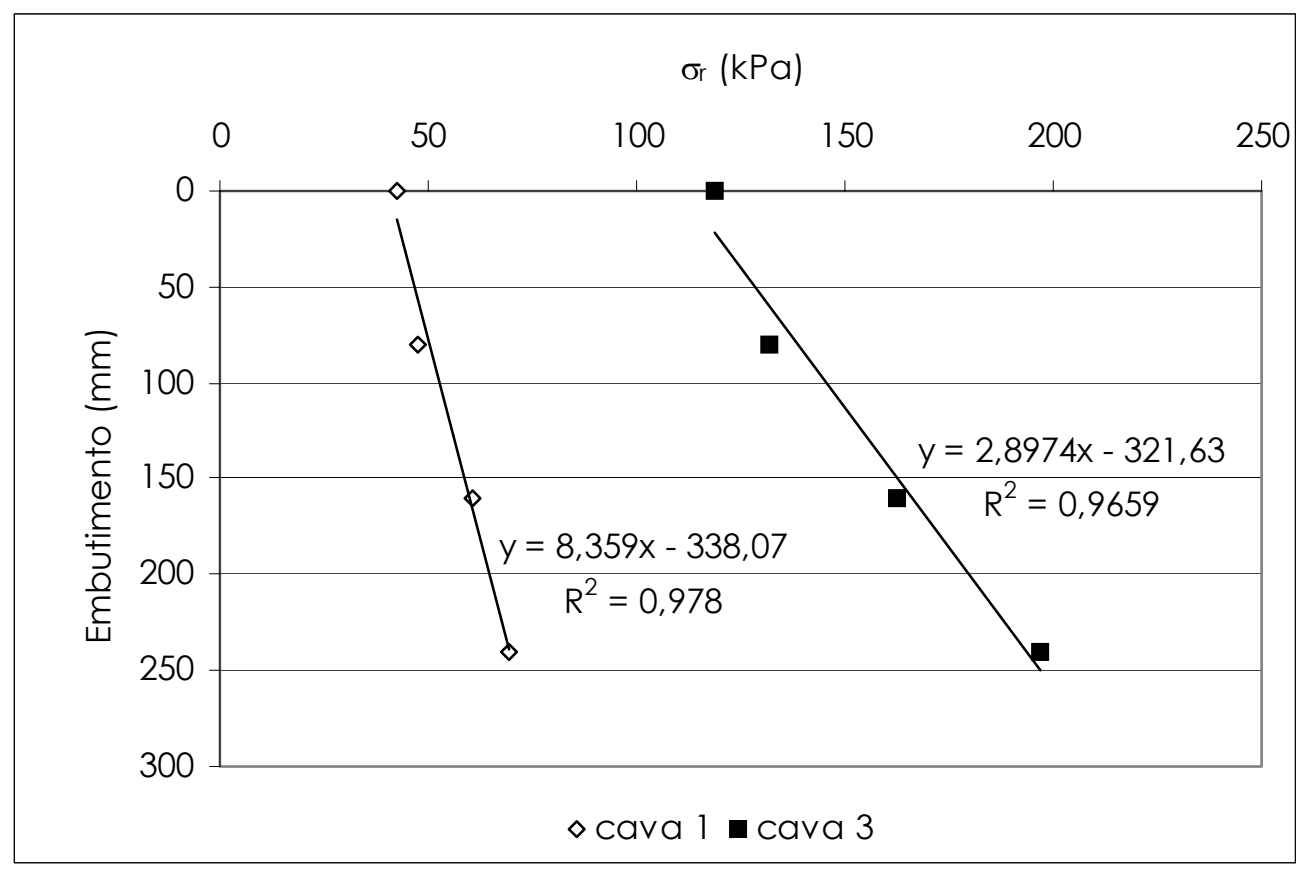

Figura 6.17 - Embutimento x capacidade de carga (os marcadores pretos representam ensaios em cavas não inundadas e os marcadores brancos, inundadas)

Tabela 6.8 - Taxas de aumento da capacidade de carga em função da cravação para as cavas 1 e 3

\begin{tabular}{|c|c|c|}
\hline Cava & $\begin{array}{c}\text { Pré- } \\
\text { inundação }\end{array}$ & $\begin{array}{c}\text { Taxa } \\
(\mathrm{kPa} / \mathrm{mm})\end{array}$ \\
\hline 3 & não & 0,35 \\
\hline 1 & $\operatorname{sim}$ & 0,12 \\
\hline
\end{tabular}

O valor da taxa de aumento na cava inundada foi $68 \%$ menor que na cava não inundada.

\subsubsection{INFLUÊNCIA DA SUCÇÃO MATRICIAL}

Na Figura 6.18 tem-se a variação da sucção matricial média ao longo do 
tempo, medida através de tensiômetros instalados em uma cava de controle no campo experimental. As setas indicam as datas em que foram realizados os ensaios em cavas não inundadas. Estão também plotadas as precipitações médias diárias fornecidas pela Embrapa Pecuária Sudeste (Fazenda Canchim, São Carlos-SP). Observa-se que a diminuição da sucção está relacionada à ocorrência de chuvas.

Os valores de pressão de sucção matricial medidos durante os ensaios variaram entre 5 e 41 kPa. Através da curva característica apresentada na Figura 6.19, pode ser observado que para valores de sucção entre 1 e 10 kPa, é necessária uma grande variação da umidade volumétrica para variar a sucção matricial. Já os valores de sucção a partir de $10 \mathrm{kPa}$, que representam a grande maioria dos valores medidos, são influenciados por pequena variação da umidade volumétrica.

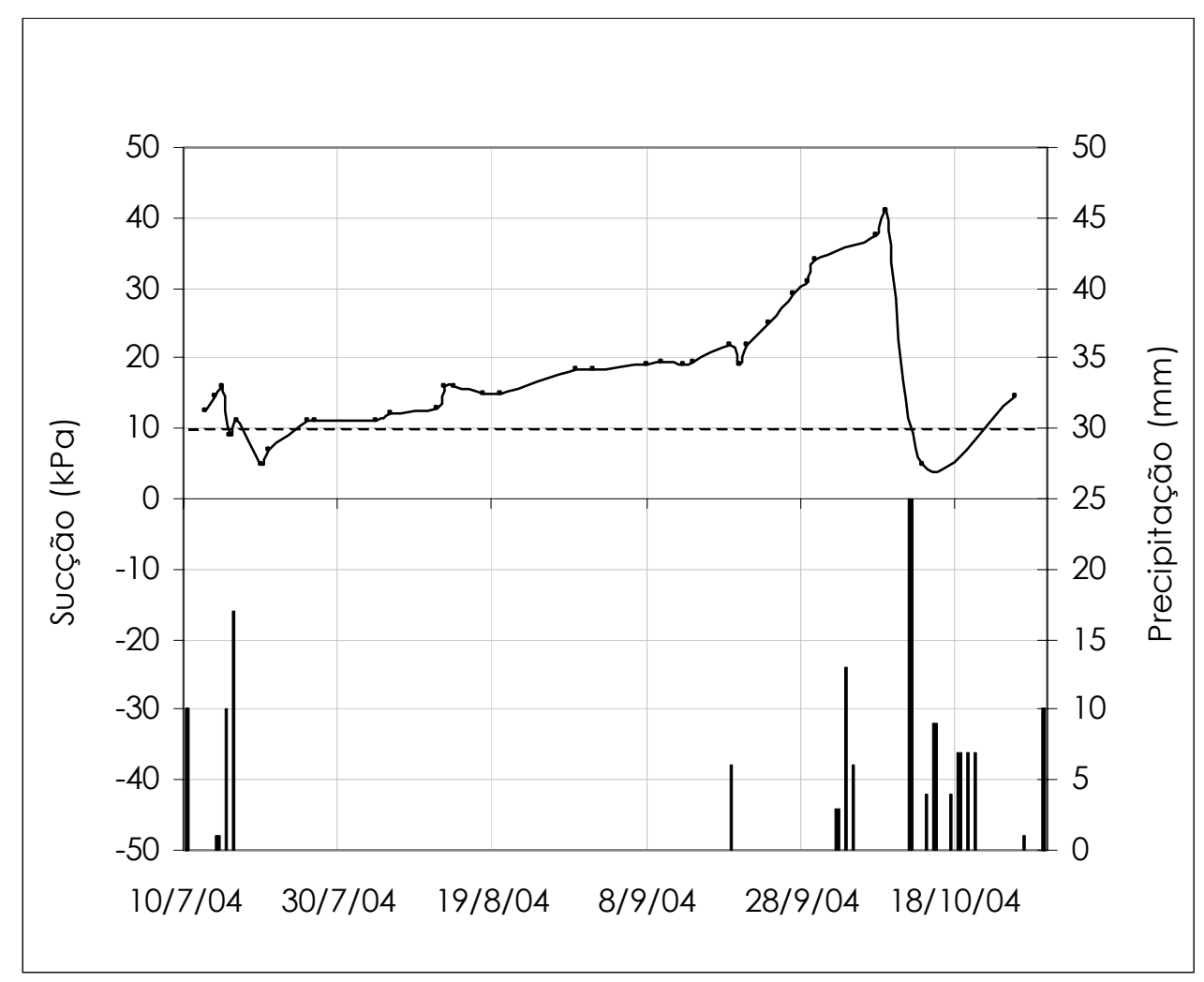

Figura 6.18 - Sucção matricial e precipitação ao longo do tempo 


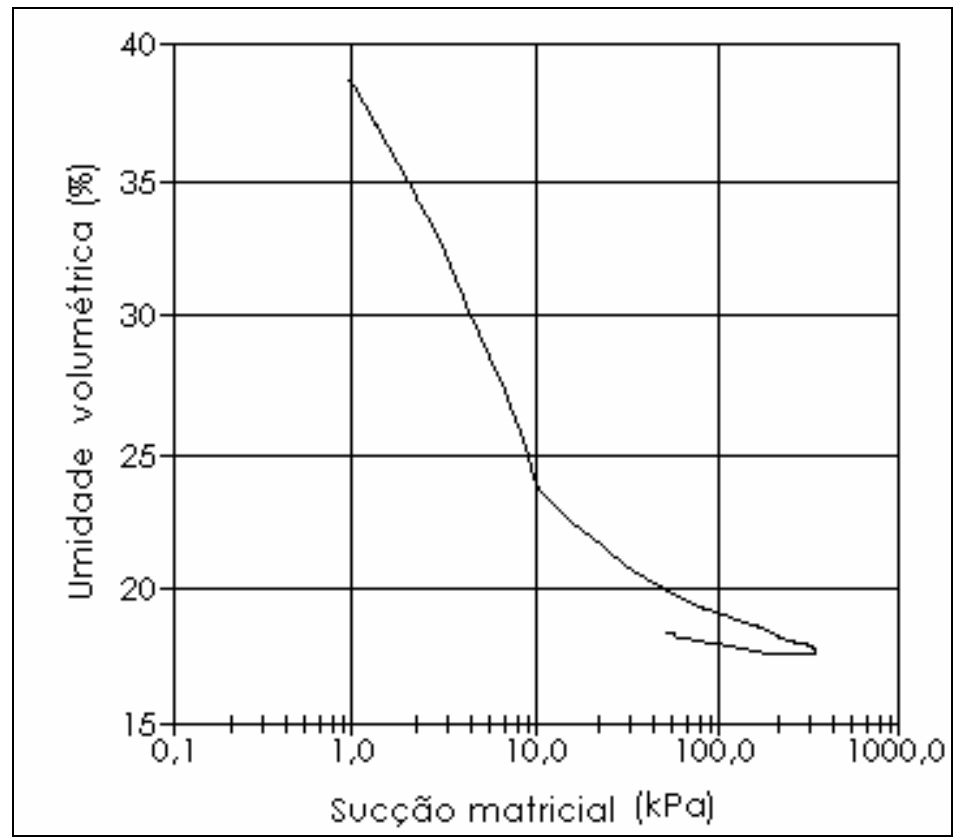

Figura 6.19 - Curva característica de sucção matricial (Machado, 1998)

\subsubsection{INFLUÊNCIA DA INUNDAÇÃO}

A Figura 6.20 mostra as curvas tensão $x$ recalque para as duas provas de carga dinâmica realizadas na cava 6. O primeiro ensaio foi executado sem inundação do terreno e o segundo com inundação prévia da cava. 


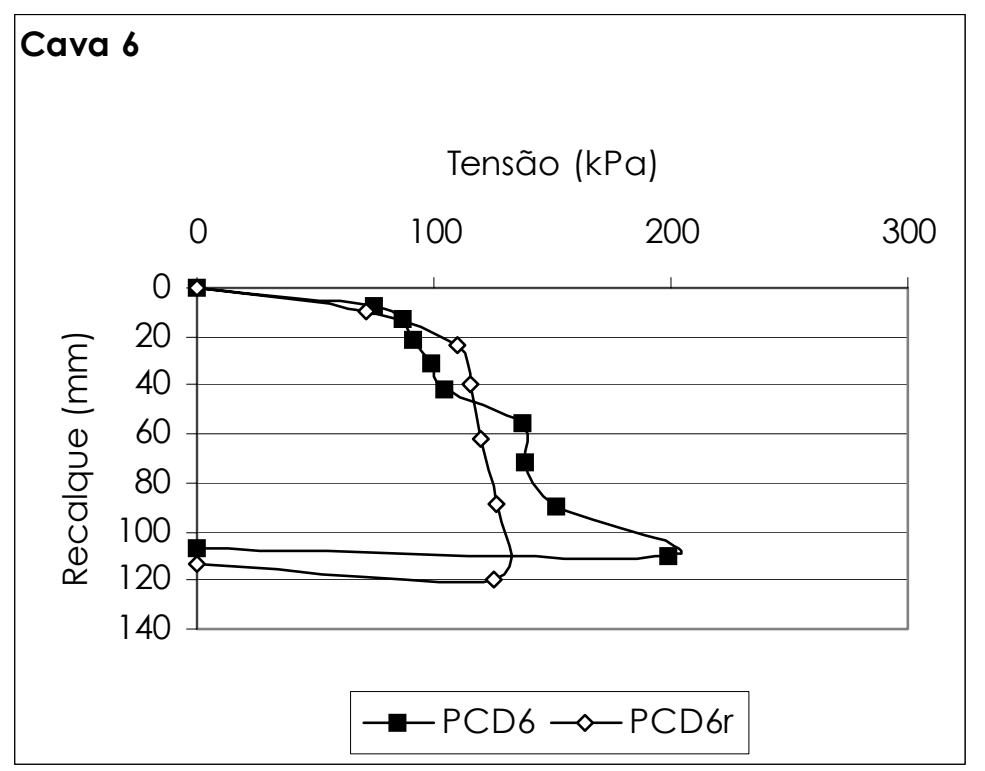

Figura 6.20 - Curvas tensão-recalque de duas provas de carga dinâmica (cava 6)

Analisando os dois ensaios como independentes, sem considerar que o segundo é um reensaio: aplicando-se o critério de ruptura convencional adotado para os demais ensaios (ruptura igual a que provoca recalque de $25 \mathrm{~mm}$ ), verifica-se que o valor da capacidade de carga encontrado para o segundo ensaio, em terreno inundado, é maior que $\mathrm{O}$ encontrado para o terreno em condição não inundada, $110 \mathrm{kPa}$ e $94 \mathrm{kPa}$, respectivamente.

Na Figura 6.21, o segundo ensaio foi plotado acumulando-se os recalques da primeira prova de carga dinâmica e o primeiro ensaio foi extrapolado até $225 \mathrm{~mm}$. 


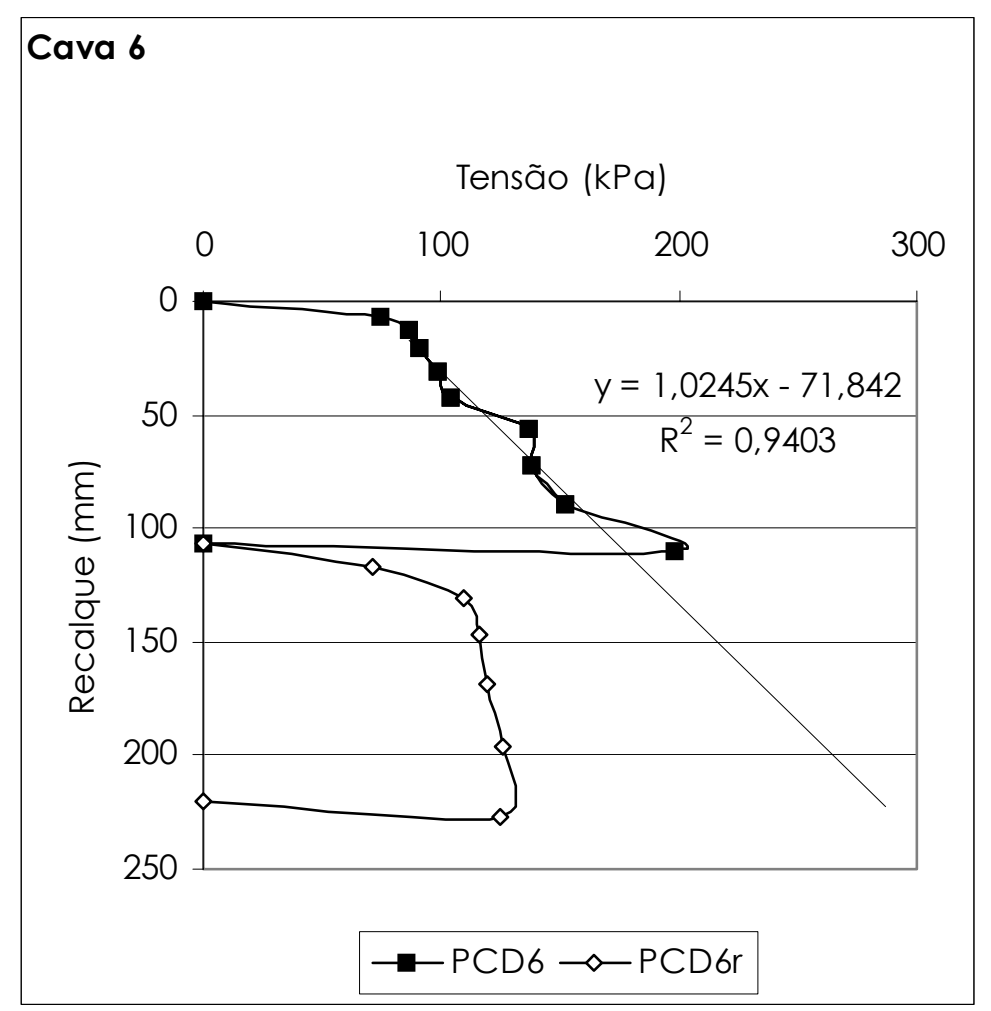

Figura 6.21 - curvas tensão-recalque das provas de carga dinâmica da cava 6, com recalques acumulados

Analisando os ensaios considerando que o primeiro ensaio modifica as condições iniciais, com os recalques acumulados, pode-se observar grande diminuição da resistência, provavelmente devido ao colapso da estrutura do solo com a dissipação da sucção matricial. Durante a realização da primeira prova de carga, a sucção era de 16 kPa, enquanto no segundo ensaio se admite sucção praticamente nula.

Na tabela 6.9 são exibidos os valores de capacidade de carga calculados em função de embutimentos hipotéticos da placa, a partir do fundo da cava, para avaliar o ganho de capacidade de carga com a cravação. Foram arbitrados comprimentos de embutimento de 0,50, 100, 150 e $200 \mathrm{~mm}$, e verificadas as capacidades de carga.

Comparando-se a capacidade de carga do segundo ensaio com a encontrada através da extrapolação do primeiro ensaio, observa-se uma redução média da capacidade de carga de $53 \%$. 
Tabela 6.9 - Valores de capacidade de carga em função do embutimento (dois ensaios, cava 6)

\begin{tabular}{|c|c|c|}
\hline $\begin{array}{c}\text { Embutimento } \\
(\mathrm{mm})\end{array}$ & $\begin{array}{c}\sigma_{r}(\mathrm{kPa}) \\
\text { PCD6 }\end{array}$ & $\begin{array}{c}\sigma_{r}(\mathrm{kPa}) \\
\text { PCD6r }\end{array}$ \\
\hline 0 & 94 & - \\
\hline 50 & 141 & - \\
\hline 100 & $192^{*}$ & 93 \\
\hline 150 & $241^{*}$ & 121 \\
\hline 200 & $290^{*}$ & 125 \\
\hline
\end{tabular}

* valores extrapolados

\subsection{ANÁlise dAS PROVAS DE CARGA DINÂMICA ATRAVÉS DE ENERGIA}

Outra forma de validar as provas de carga dinâmica em placa é comparando-se a energia fornecida pelo PDA com a energia calculada a partir dos resultados obtidos. As Figuras 6.22 a 6.29 apresentam os gráficos de energia máxima aplicada, acumulada, fornecida pelo PDA, plotada contra a energia máxima acumulada, calculada.

A energia calculada é a área sob cada curva força-recalque (Figuras 6.2 a 6.9). Foram calculados dois valores de energia: um deles utilizando a força encontrada pelo método CASE e outro utilizando a força obtida através das análises CAPWAP®. 


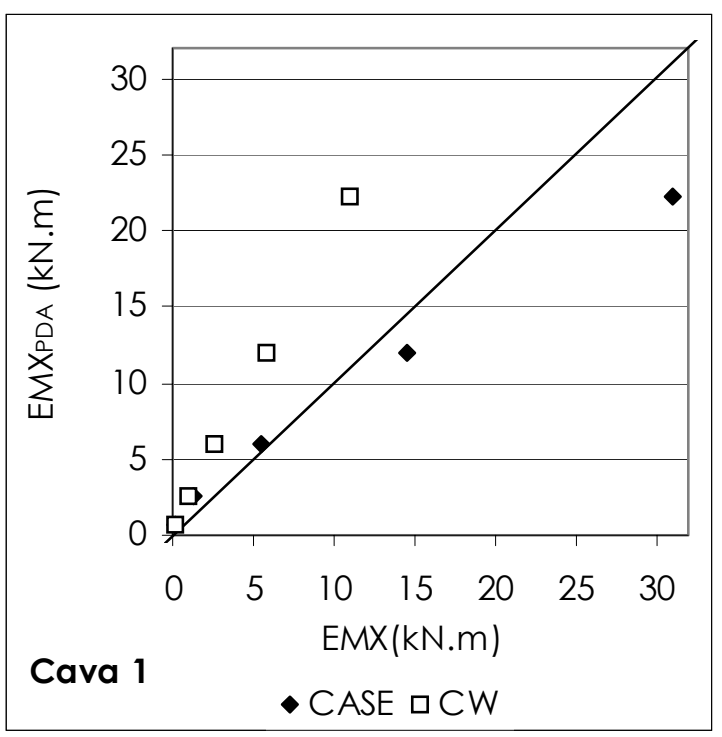

Figura 6.22 - Energia fornecida pelo PDA x energia calculada (cava 1)

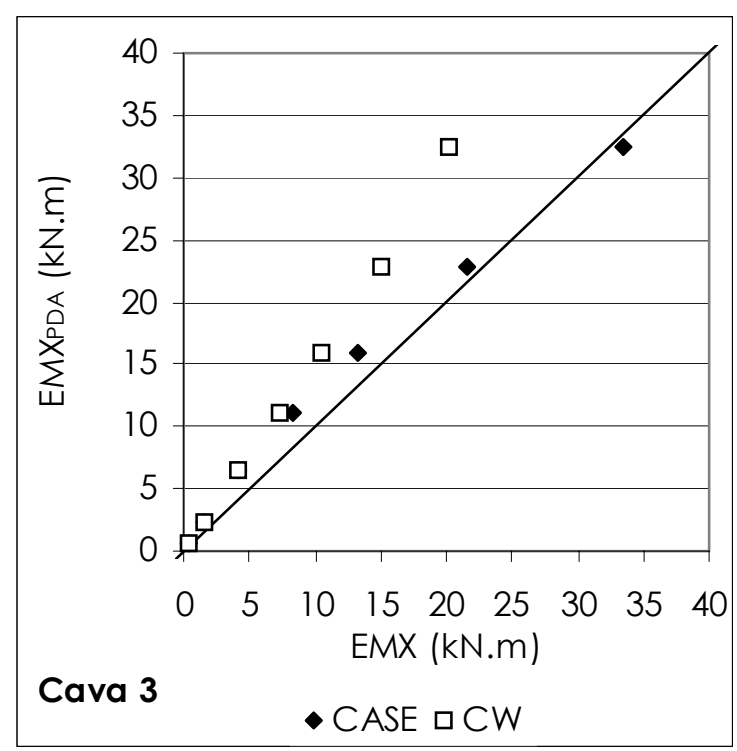

Figura 6.23 - Energia fornecida pelo PDA x energia calculada (cava 3) 


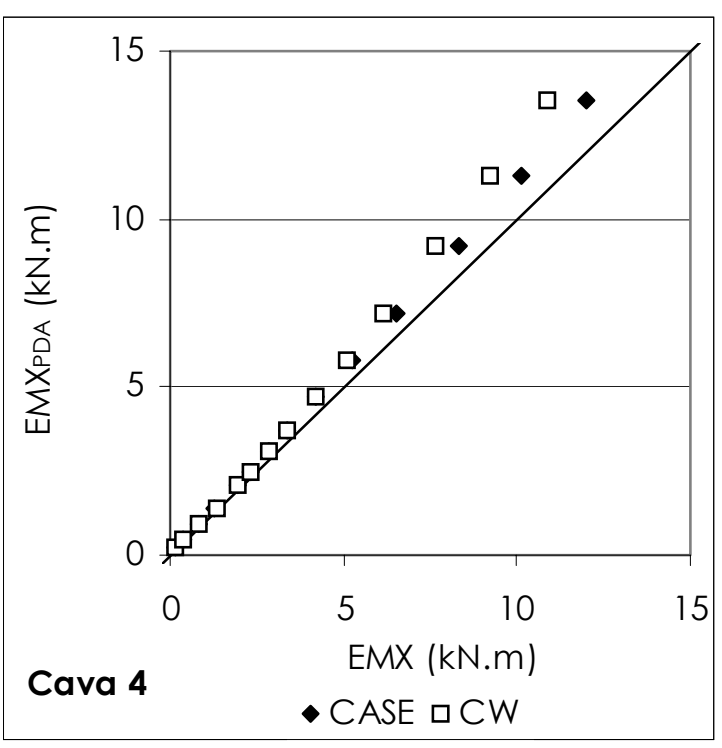

Figura 6.24 - Energia fornecida pelo PDA x energia calculada (cava 4)

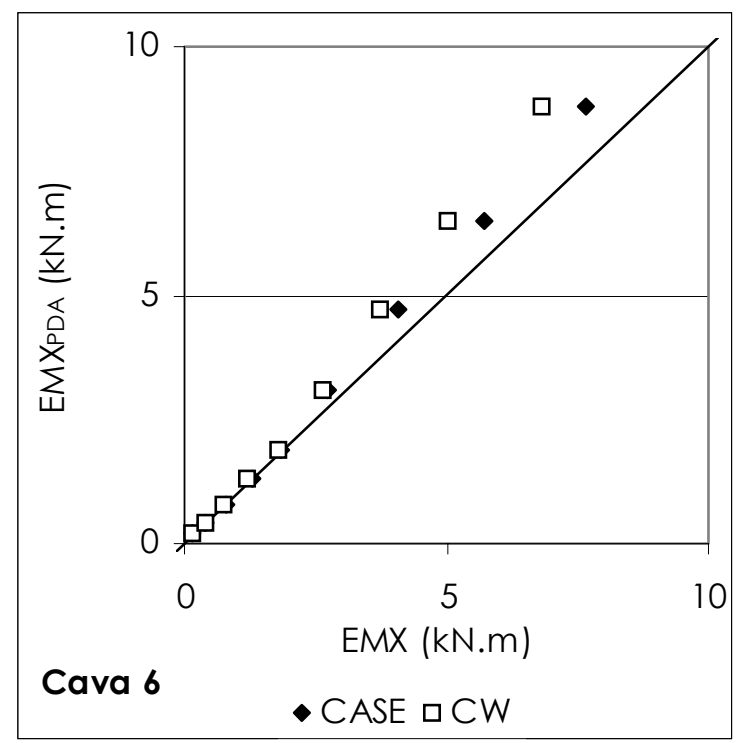

Figura 6.25 - Energia fornecida pelo PDA x energia calculada (cava 6) 


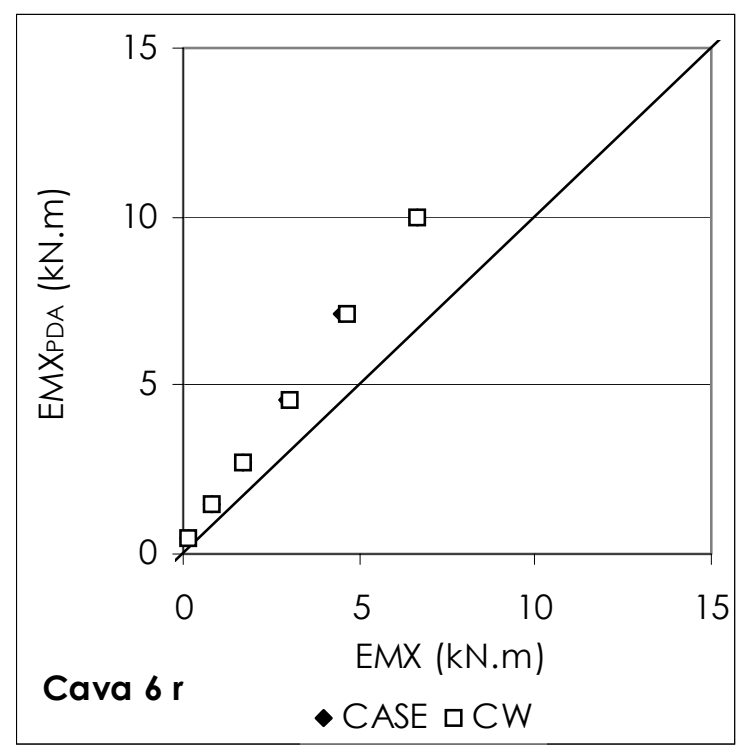

Figura 6.26 - Energia fornecida pelo PDA x energia calculada (cava 6-reensaio)

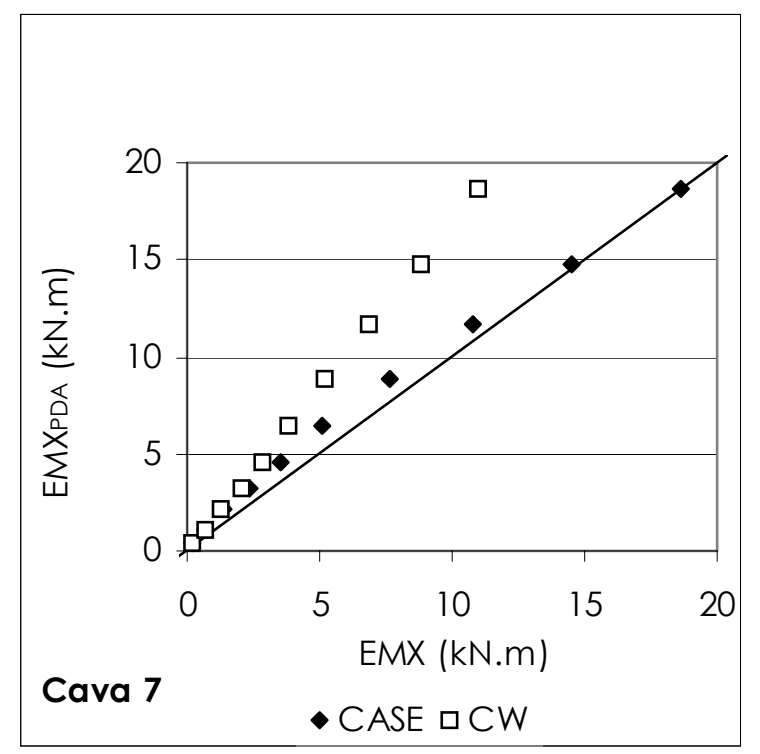

Figura 6.27 - Energia fornecida pelo PDA x energia calculada (cava 7) 


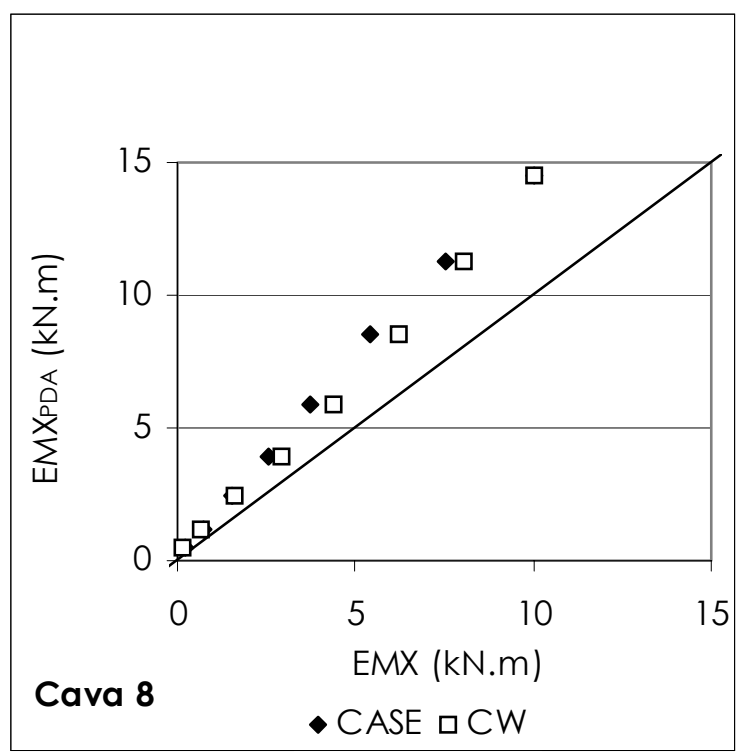

Figura 6.28 - Energia fornecida pelo PDA x energia calculada (cava 8)

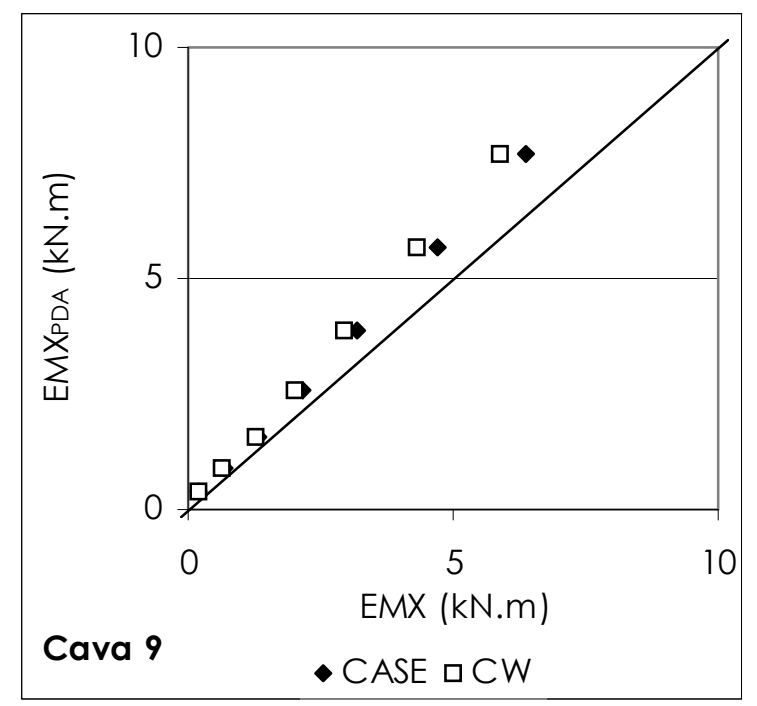

Figura 6.29 - Energia fornecida pelo PDA x energia calculada (cava 9)

A energia calculada utilizando os valores de força obtidos pelos métodos CASE e CAPWAP® se aproximou da energia fornecida pelo PDA, validando a prova de carga dinâmica em placa.

No geral, os valores de energia calculados foram um pouco menores que os 
fornecidos pelo PDA, talvez porque o PDA fornece a energia total aplicada ao sistema, mas parte dela é perdida em forma de "energia de compactação".

\subsection{PARCELAS DE DESLOCAMENTO}

A resistência estática mobilizada é adimensionalizada em função da resistência estrutural do tubo de aço (RE), a qual foi calculada como sendo igual a:

$$
R E=f_{y} A=250 \cdot 2,71 \cdot 10^{-3}=0,679 \mathrm{MN}=679 \mathrm{kN}
$$

Já o deslocamento é adimensionalizado em função do diâmetro da placa. As Figuras 6.30 a 6.36 mostram a variação do deslocamento adimensionalizado total (D), permanente (S) e elástico (K). Os valores de S foram medidos com papel e lápis, D é o deslocamento máximo DMX fornecido pelo PDA e K é a diferença entre os dois, já que não foi possível obter a medida em campo com papel e lápis. A análise das parcelas de deslocamento das provas de carga dinâmica, apresentadas nas Figuras 6.30 a 6.37 , confirmam os resultados obtidos por Niyama \& Aoki (1991) e Lima (1999). Os repiques aumentam com a energia aplicada, até atingir um limite máximo, em torno do qual se estabilizam, mesmo que a energia continue a aumentar, enquanto as negas tendem a um valor próximo de zero para os níveis de energia mais baixos e, com o aumento da energia, crescem cada vez mais.

Observa-se que para os ensaios inundados (Figuras 6.30, 6.34, 6.35 e 6.36) há uma tendência de verticalização da curva para percentuais baixos da resistência estrutural do tubo de aço: 5, 9, 8 e 8\%, respectivamente, o que indica que o comportamento do sistema é comandado pela resistência do solo (Aoki, 1991 e Campelo, 2000). As curvas dos ensaios não inundados, mesmo adimensionalizadas, continuaram apresentando resistências 
mobilizadas crescentes com o nível de energia. Novas análises poderiam ser feitas para verificar se haveria aumento da resistência mobilizada até o limite da resistência estrutural do tubo. Verifica-se que a adimensionalização induz a uma tendência de linearização ou verticalização das curvas.

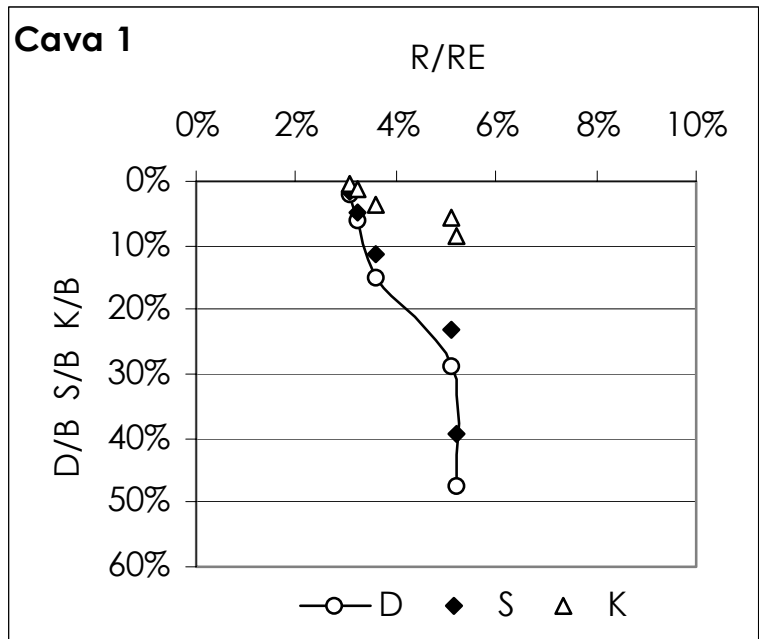

Figura 6.30 - Evolução do repique e da nega na prova de carga dinâmica com energia crescente (cava 1)

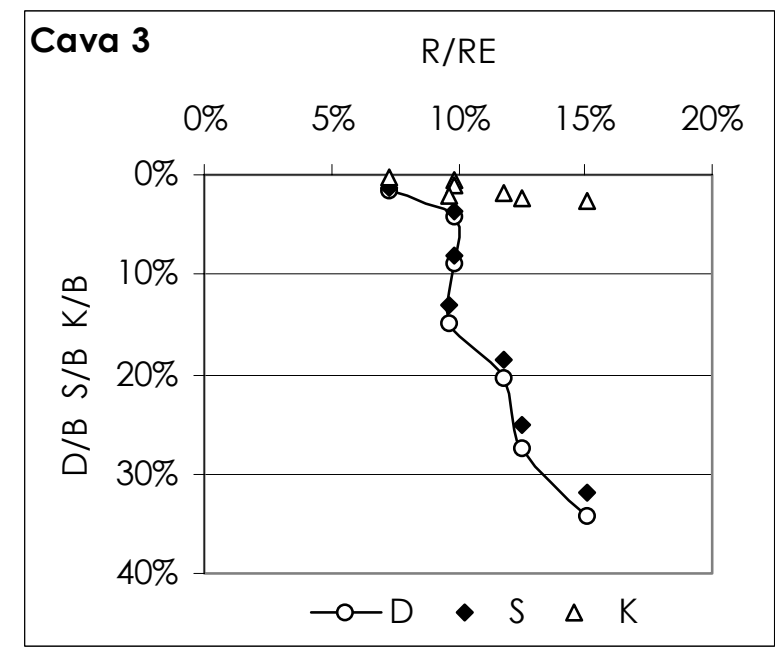

Figura 6.31 - Evolução do repique e da nega na prova de carga dinâmica com energia crescente (cava 3 ) 


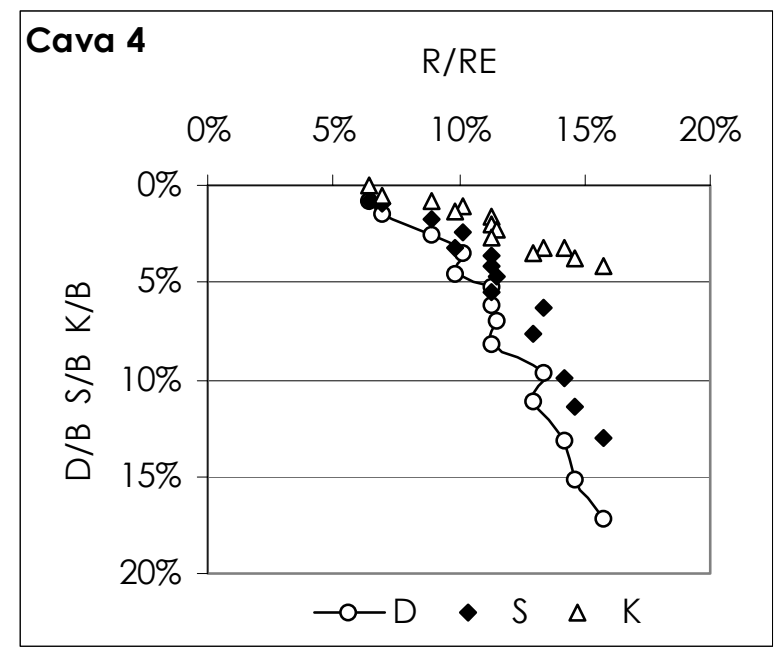

Figura 6.32 - Evolução do repique e da nega na prova de carga dinâmica com energia crescente (cava 4 )

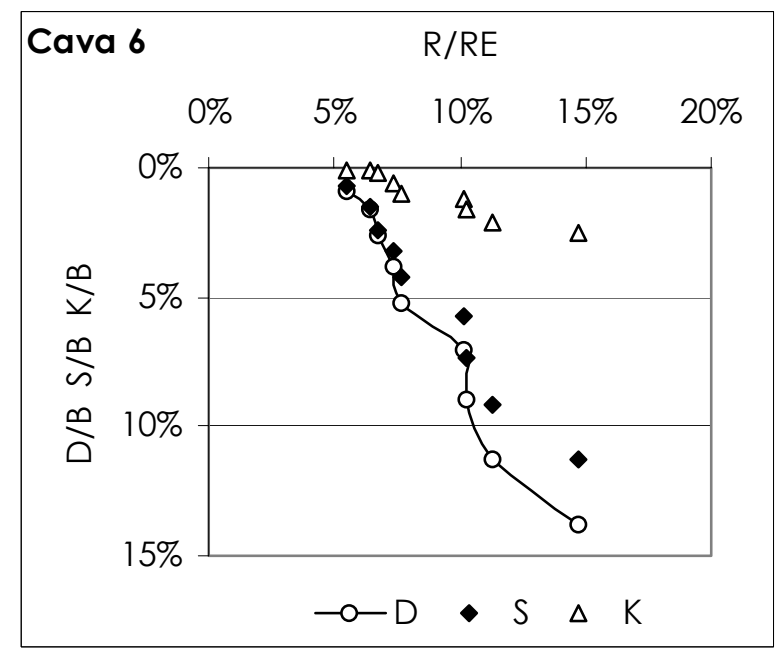

Figura 6.33 - Evolução do repique e da nega na prova de carga dinâmica com energia crescente (cava 6) 


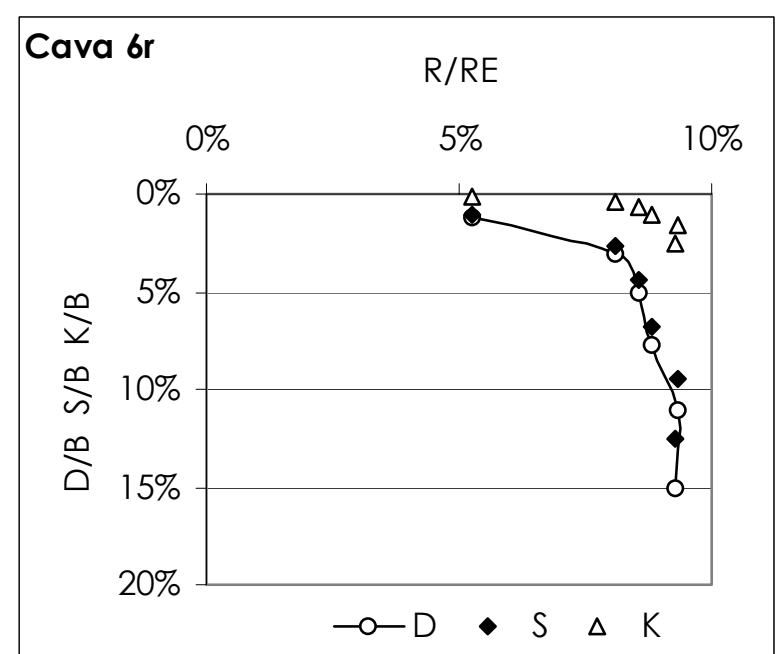

Figura 6.34 - Evolução do repique e da nega na prova de carga dinâmica com energia crescente (cava br)

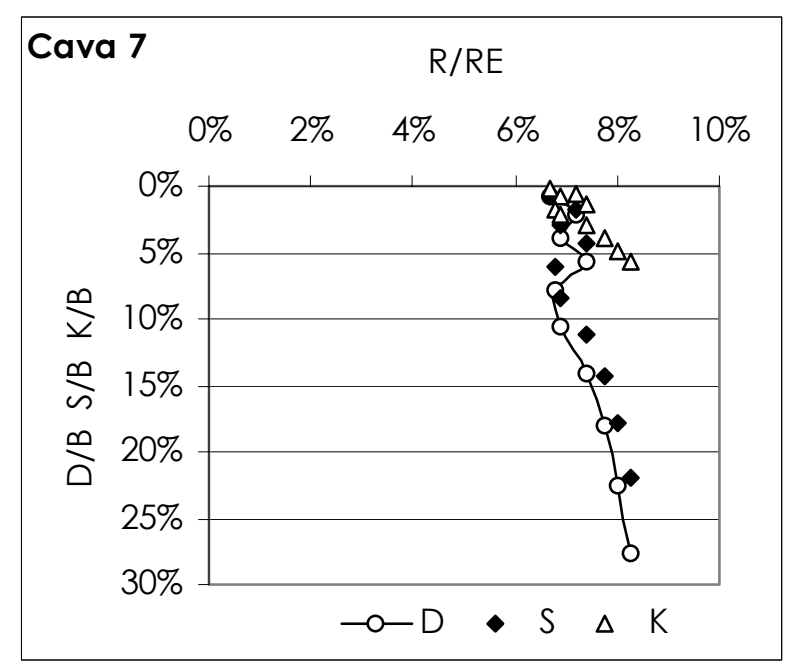

Figura 6.35 - Evolução do repique e da nega na prova de carga dinâmica com energia crescente (cava 7) 


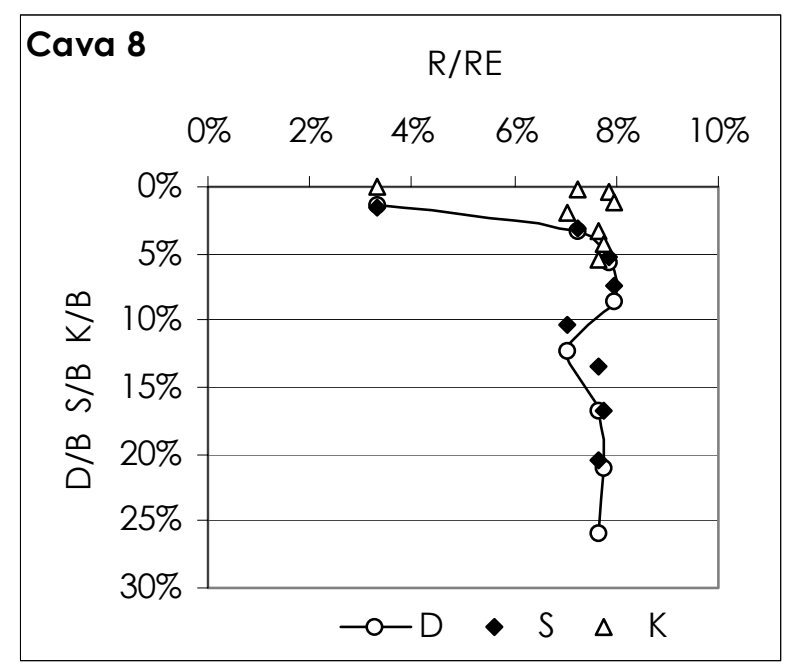

Figura 6.36 - Evolução do repique e da nega na prova de carga dinâmica com energia crescente (cava 8)

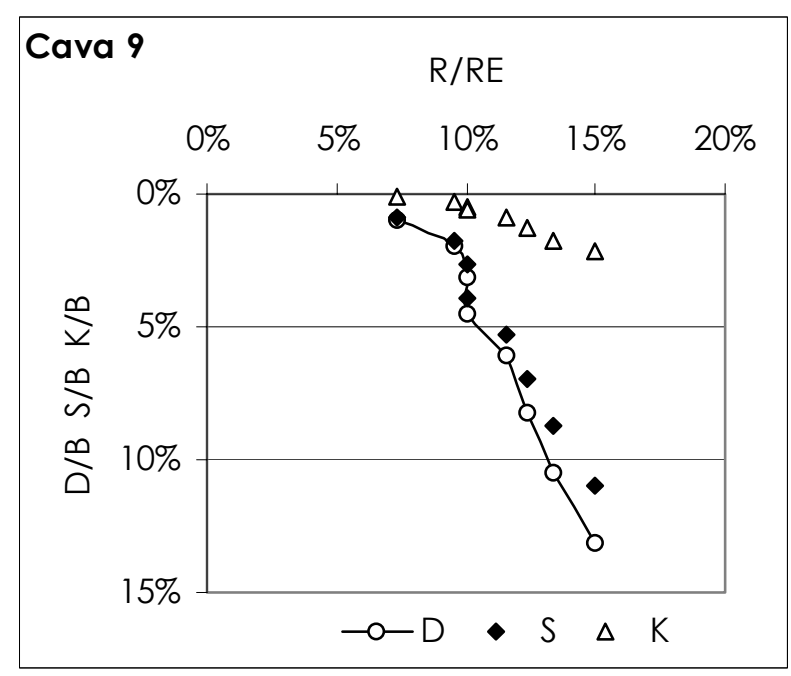

Figura 6.37 - Evolução do repique e da nega na prova de carga dinâmica com energia crescente (cava 9) 


\section{CONCLUSÃO}

Esta dissertação contribui com a engenharia de fundações, validando a adaptação da prova de carga dinâmica para placa metálica rígida de diâmetro 0,80 m. O ensaio dinâmico passa a ser uma alternativa às provas de carga estática em placa.

As conclusões obtidas nos estudos realizados são as seguintes:

\section{Análises CAPWAP®:}

Todos os golpes de cada prova de carga dinâmica foram analisados com o auxílio do programa CAPWAP®. Houve, no geral, boa coincidência entre as curvas de força medida e calculada, apesar de a ferramenta não ter sido desenvolvida para este tipo de análise e de travar constantemente.

Nos ensaios em que foram adotados incrementos de energia maiores, notou-se a necessidade de não somente analisar todos os golpes de cada série, mas também ter um número total de golpes suficiente para uma boa definição da curva resistência mobilizada $x$ deslocamento. Quanto menores os incrementos de energia, melhor a definição da curva. Na prova de carga dinâmica os incrementos de energia devem ser programados de forma que se tenha um número adequado de pontos.

\section{Comparação entre os métodos CASE e CAPWAP®:}

Nas análises pelo método simplificado CASE foi adotado um Jc (constante de amortecimento) para os ensaios inundados igual a 0,40 e outro para os não inundados, igual a 0,25 . O motivo que levou à adoção de valores diferentes de $J_{c}$ foi o comportamento apresentado pelo solo quanto inundado, que se assemelhava a um solo argiloso, quando na verdade era um solo arenoso. Houve boa concordância entre as análises CAPWAP® e 
CASE.

Foi observado que quanto maior a energia aplicada ao sistema no momento do golpe, maior a diferença entre os dois métodos, confirmando que Jc aumenta com a energia.

A análise pelo método CASE, apesar de bastante criticada, porque utiliza o mesmo Jc para toda a seqüência de golpes, é útil na comprovação da capacidade de carga em campo, simultaneamente à realização de um ensaio.

\section{Comparação entre provas de carga dinâmica e estática em placa:}

Como foi utilizado o ensaio com energia crescente, foi possível traçar curvas tensão resistente $\mathrm{x}$ deslocamento, semelhantes às curvas carga $\mathrm{x}$ recalque de provas de carga estática.

Comparando os resultados obtidos através de análises CAPWAP®, golpe a golpe, com os obtidos nas provas de carga estática, realizadas antes e depois dos ensaios dinâmicos, observa-se uma aproximada continuidade das curvas, o que indica a viabilidade do uso do ensaio dinâmico em placa.

\section{Influência do embutimento na capacidade de carga:}

Nas cavas em que foram realizadas provas de carga dinâmica e estática, as três curvas tensão $\mathrm{x}$ recalque de cada cava foram consideradas uma curva única, com razoável coerência, desconsiderando o descarregamento e o carregamento subseqüente, até atingir a tensão máxima do ensaio anterior. A parte final das curvas dos sucessivos ensaios de uma mesma cava constitui uma espécie de trecho reto único. Observou-se que a capacidade de carga cresce com o embutimento da placa a partir do fundo da cava. Sem considerar o embutimento, os valores obtidos foram $102 \mathrm{kPa}$ para cavas não inundadas 
e $64 \mathrm{kPa}$ para as inundadas, respectivamente. Considerando-se o benefício do embutimento de $150 \mathrm{~mm}$, observa-se aumento médio da capacidade de carga de 137\% para as cavas não inundadas. Nas cavas inundadas, para um embutimento de $300 \mathrm{~mm}$, o aumento foi de $169 \%$.

Nas duas cavas em que foram realizadas somente provas de carga dinâmica, com incrementos de energia maiores, o embutimento de $30 \%$ do diâmetro da placa conferiu um aumento aproximado de $65 \%$ da capacidade de carga em relação àquela sem embutimento, de 42 kPa para 69 kPa na cava inundada e de 119 kPa para 197 kPa na cava não inundada.

Para todas as cavas, as taxas de aumento da capacidade de carga em função da cravação dos ensaios inundados apresentaram valores em média $65 \%$ menores que os não inundados.

\section{Influência da inundação na capacidade de carga:}

Numa mesma cava foram realizadas duas provas de carga dinâmica, a primeira com terreno não inundado e a segunda em condição de inundação. Analisando-se os dois ensaios em conjunto, com os recalques acumulados, observa-se grande diminuição da resistência no ensaio inundado, provavelmente devido ao colapso da estrutura do solo com a dissipação da sucção matricial.

Comparando-se a capacidade de carga obtida no segundo ensaio com as encontradas através da extrapolação do primeiro ensaio, com sucção matricial igual a 16 kPa, observa-se uma redução média da capacidade de carga de 53\%.

\section{Análises das provas de carga dinâmica através de energia:}

A energia calculada utilizando os valores de força resistente obtidos pelos métodos 
CASE e CAPWAP® se aproximou bastante da energia fornecida pelo PDA, validando a prova de carga dinâmica em placa, e as análises e modelos usados.

No geral, os valores de energia calculados foram um pouco menores que os fornecidos pelo PDA, provavelmente porque o PDA fornece a energia aplicada ao sistema, e parte dela é perdida em forma de "energia de compactação".

\section{Parcelas de deslocamento em curvas adimensionalizadas:}

O repique aumenta com a energia aplicada, até atingir um limite máximo, em torno do qual se estabiliza, mesmo que a energia continue a aumentar, enquanto a nega tende a um valor próximo de zero para os níveis de energia mais baixos e, com o aumento da energia, passa a crescer cada vez mais.

Verifica-se que a adimensionalização induz a uma tendência de linearização ou verticalização das curvas, dependendo da condição de inundação. Para os ensaios inundados há uma tendência de verticalização da curva em torno de $7,5 \%$ da resistência estrutural do tubo de aço, o que indica que o comportamento do sistema é comandado pela resistência do solo.

Já as curvas tensão-recalque dos ensaios não inundados, mesmo adimensionalizadas, continuaram apresentando resistências mobilizadas crescentes com o nível de energia, indicando a possibilidade do comportamento do sistema ser comandado pela resistência estrutural do tubo, apesar desta ter sido pouco mobilizada. As várias provas de carga em placa e sapata realizadas no local, em diversas pesquisas, fazem crer que a resistência mobilizada aumentaria até o escoamento do aço do tubo. 


\section{REFERÊNCIAS BIBLIOGRÁFICAS}

ABNT (1984). Prova de Carga Direta sobre Terreno de Fundação. NBR 6489, Rio de Janeiro.

ABNT (1991). Estacas - Prova de Carga Estática. NBR 12131, Rio de Janeiro, 4 p.

ABNT (1994). Estacas - Ensaio de Carregamento Dinâmico. NBR 13208, Rio de Janeiro.

ABNT (1996). Estacas - Projeto e Execução de Fundação. NBR 6122, Rio de Janeiro, 33 p.

ADAM, C. \& ADAM, D. (2003). Modeling of the dynamic load plate test with the Light Falling Weight Device. In: ASIAN JOURNAL OF CIVIL ENGINEERING. BUILDING AND HOUSING, vol. 4, NOS 2-4, p. 73 a 89.

ALVES, A. M. L. (2004). A influência da viscosidade do solo e do tempo após a cravação na interação dinâmica estaca-solo em argilas. Rio de Janeiro. 204 p. Tese de Doutoramento. COPPE, Universidade Federal do Rio de Janeiro.

AOKI, N. (1989). A new dynamic load test concept. In: XII INTERNATIONAL CONFERENCE ON SOIL MECHANICS AND FOUNDATION ENGINEERING. TC Pile Driving. Rio de Janeiro. Pgs for the Discussion Section 14, v.1, pl-4.

AOKI, N. (1991). Carga Admissível de Estacas Através de Ensaio Dinâmico. In: II SEMINÁRIO DE ENGENHARIA DE FUNDAÇÕES ESPECIAIS, São Paulo. Anais, v.2, p.269-292.

AOKI, N. (1997). Determinação da Capacidade de Carga Última de Estaca Cravada em Ensaio de Carregamento Dinâmico de Energia Crescente. São Carlos. 111 p. Tese de Doutoramento. Escola de Engenharia de São Carlos, Universidade de São Paulo. 
AOKI, N. (2000). Keynote lecture: Improving the reliability of pile bearing capacity prediction by the dynamic increasing energy test (DIET). In: Niyama, S.; Beim, J. (eds) APPLICATION OF STRESS-WAVE THEORY TO PILES, Balkema, Rotterdam, p. 635-650.

ANDREO, C. S.; GONÇALVES, C.; BERNARDES, G. (2000). Utilização do ensaio de carregamento dinâmico para avaliação da carga mobilizada em estacas quadradas cravadas em folhelho da formação Taubaté / SP. In: IV SEMINÁRIO DE ENGENHARIA DE FUNDAÇÕES ESPECIAIS, São Paulo. Anais, v.1, p. 148 a 155.

BENVENUTTI, M. (2001). Cravação de Tubulões a Céu Aberto para Melhoria da Capacidade de Carga em Solos Colapsíveis. São Carlos. 115 p. Dissertação de Mestrado. Escola de Engenharia de São Carlos. Universidade de São Paulo.

BERNARDES, G.; NORDAL, S. (1991). Estudo da Capacidade de Carga de Estacas Modelo Através de Ensaios Estáticos e Dinâmicos. In: II SEMINÁRIO DE ENGENHARIA DE FUNDAÇÕES ESPECIAIS, São Paulo. Anais, v.1, p. 17-30.

BORTOLUCCl, A. A. (1983). Caracterização geológico-geotécnica da região urbana de São Carlos - SP. São Carlos. 67 p. Dissertação de Mestrado. Escola de Engenharia de São Carlos. Universidade de São Paulo.

BUTLER, H. D.; HOY, H. E. (1977). User's manual for the Texas quick-load method for foundation load testing. Federal Highway Administration. Office of development. Washington. 59 p.

CAMPELO, N. (2000). Comportamento de Tubulões Escavados a Céu Aberto, Submetidos a Carregamentos Dinâmicos, em Solo Colapsível. São Carlos. 319 p. Tese de Doutoramento. Escola de Engenharia de São Carlos. Universidade de São Paulo.

CAMPELO, N.; CINTRA, J. C. A.; AOKI, N.; ALBIERO, J. H.; CARNEIRO, B. J. I. C. (2000). 
Análise da Resistência Mobilizada em Tubulões Através do PDA. In: IV SEMINÁRIO DE ENGENHARIA DE FUNDAÇÕES ESPECIAIS, São Paulo. Anais, ABMS/ABEF, v. 1, p. 127 a 136.

CAMPOS, L. E. P.; MENEZES, M. S. S.; PRESA, E. P.; FONSECA, E. C. (1994). Considerações Sobre a Análise de Estabilidade de Taludes em Solos Não Saturados. In: 20 SIMPÓSIO SOBRE SOLOS NÃO SATURADOS, Recife. Anais, v. 1, p. 249 a 252.

CHIN, F. K. (1970). Estimation of the ultimate load of piles not carried to failure. In: II SOUTHEAST ASIAN CONFERENCE ON SOIL ENGINEERING. Proceedings. P. 81-90.

CINTRA, J. C. A. (1998). Fundações em Solos Colapsíveis. São Carlos, Serviço Gráfico da Escola de Engenharia de São Carlos, Universidade de São Paulo.

CINTRA, J. C. A.; CARVALHO, D.; GIACHETtI, H. L.; BORTOlluUCl, A. A.; ALBIERO, J. H. (1991). Campo Experimental de Fundações em São Carlos. In: ॥l SEMINÁRIO DE ENGENHARIA DE FUNDAÇÕES ESPECIAIS, São Paulo. Anais, ABMS/ABEF, v. 1, p. 96 a 105.

CINTRA, J. C. A.; AOKI, N.; ALBIERO, J. H. (2003). Tensão Admissível em Fundações Diretas, São Carlos, RiMa.

COSTA, Y. D. J. (1999). Estudo do Comportamento de Solo Não Saturado Através de Provas de Carga em Placa. Dissertação de Mestrado. Escola de Engenharia de São Carlos. Universidade de São Paulo.

DAVISSON, M. T. (1972). High Capacity Piles. Proceedings of Lecture Series on Innovations in Foundation Construction. ASCE, Illinois Section. Chicago. p. 81-112

DE BEER, E. E. (1967). Proefondervindelijke bijdrage tot de studie van het grensdraag vermogen van zand onder funderingen op staal. Tijdshrift der Openbar Werken van Beigie Nos. 
FELLENIUS, B. H. (1975). Test Load of Piles and New Proof Test Procedure. In: JOURNAL OF GEOTECHNICAL ENGINEERING DIVISION. ASCE, vol. 101, GT9, p. 855 a 869.

FELLENIUS, B. H. (1980). The Analysis of Results from Routine Pile Load Tests. In: GROUND ENGINEERING DIVISION. Foundations publication, Ltd., vol. 13, n. 6, p. 19 a 31.

FREDLUND, D. G.; RAHARDJO, H. (1993). Soil Mechanics for Unsaturated Soils, New York, John Wiley \& Sons.

FULLER, F. M.; HOY, H. E. (1970). Pile load tests including quick-load test method, conetional methods and interpretations. Highway Research Board, 333. p. 78-86.

GIACHETI, H. L.; ROHM, S. A.; NOGUEIRA, J. B.; CINTRA, J. C. A. (1993). Propriedades geotécnicas do sedimento cenozóico. In: FERREIRA, A. A.; NEGRO JUNIOR, A.; ALBIERO, J. H.; CINTRA, J. C. A. orgs. Solos do Interior de São Paulo. São Paulo, ABMS, USP/SC. Cap. 6, p. 143175.

GUSMÃO FILHO, J. A. (1994). Fundações em Solos Não Saturados. In: 20 SIMPÓSIO SOBRE SOLOS NÃO SATURADOS, Recife. Anais, v. 1, p. 217 a 230.

HANNIGAN, P. J. (1990). Dynamic Monitoring and Analysis of Pile Foundation Instalations. Continuing education committee of DEEP FOUNDATION INSTITUTE.

JENNINGS, J. E. \& KNIGHT, K. (1975). A guide to construction on or with materials exhibiting additional settlement due to "collapse" of grain structure. In: VII REGIONAL CONFERENCE FOR AFRICA ON SOIL MECHANICS AND FOUNDATION ENGINEERING. Durban, v. 1, p. 99-105.

KORMANN, A. C. M.; CHAMECKI, P. R.; RUSSO, L.; ANTONIUTTI, L.; BERNARDES, G. P. (2000). Estacas Hélice Contínua em argila sobreadensada: comportamento em provas de 
carga estáticas e dinâmicas. In: IV SEMINÁRIO DE ENGENHARIA DE FUNDAÇÕES ESPECIAIS, São Paulo. Anais, ABMS/ABEF, v. 1, p. 58 a 70.

LIMA, F. M. A. (1999). Análise de Prova de Carga Dinâmica em Estacas Metálicas do Tipo Trilho. São Carlos. 92p. Dissertação de Mestrado. Escola de Engenharia de São Carlos, Universidade de São Paulo.

MACHADO, S. L. (1998). Aplicação de Conceitos de Elastoplasticidade a Solos Não Saturados. Tese de Doutoramento. São Carlos. 351 p. Escola de Engenharia de São Carlos, Universidade de São Paulo.

MAZURKIEWICZ, B. K. (1972). Test loading of piles according to Polish regulations. Royal Swedish Academy of Engineering Sciences. Report n. 35. Stockolm. 20 p.

NIYAMA, S.; AOKI, N. (1991). Correlação Entre Provas de Carga Dinâmica e Estática no Campo Experimental da EPUSP/ABEF. In: ॥ SEMINÁRIO DE ENGENHARIA DE FUNDAÇÕES ESPECIAIS, São Paulo. Anais, v.1, p. 285-293.

NAVAJAS, S.; NIYAMA, S. (1996). Ensaio de carregamento dinâmico em estacas moldadas in loco numa obra portuária. In: III SEMINÁRIO DE ENGENHARIA DE FUNDAÇÕES ESPECIAIS, São Paulo. Anais, ABMS/ABEF, v. 1, p. 331 a 342.

NIYAMA, S.; AOKI, N.; CHAMECKI, P. R. (1998). Verificação de desempenho. In: HACHICH, W.; FALCONI, F.; SAES, J. L.; FROTA, R.; CARVALHO, C.; NIYAMA, S. eds. Fundações: teoria e prática. 2 ed. São Paulo, PINI. Cap. 20, p.723 a 751.

RAUSCHE, F.; GOBLE, G. G.; LIKINS, G. E. (1985). Dynamic Determination of Pile Capacity. In: JOURNAL OF GEOTECHNICAL ENGINEERING. ASCE, vol. III, n. 3, p. 367 a 383.

SMITH, E. A. L. (1960). Pile-driving Analysis by the Wave Equation. In: JOURNAL OF SOIL 
MECHANICS AND FOUNDATION DIVISION. ASCE, vol. 86, SM4, p. 36 a 61.

SOARES, F. L. (2002). Análise de Provas de Carga Dinâmica em Tubulões a Céu Aberto no Campo Experimental de Fundações da EESC/USP. São Carlos. 158 p. Dissertação de Mestrado. Escola de Engenharia de São Carlos, Universidade de São Paulo.

TEIXEIRA, A. H.; GODOY, N. S. (1998). Análise, projeto e execução de fundações rasas. In: HACHICH, W.; FALCONI, F.; SAES, J. L.; FROTA, R.; CARVALHO, C.; NIYAMA, S. eds. Fundações: teoria e prática. 2 ed. São Paulo, PINI. Cap.7, p. 227 a 264.

TERZAGHI, K. (1943). Teorical Soil Mechanics. New York, Jonh Willey \& Sons.

VAN DER VEEN, C. (1953). The Bearing Capacity of a Pile. In: III INTERNATIONAL CONFERENCE ON SOIL MECHANICS AND FOUNDATION ENGINEERING. Zurich, v. 2, p. 84-90.

VESIC, A. S. (1963). Bearing Capacity of Deep Foundations in Sand. In: Highway Research Record, 39. National Academy of Sciences, National Research Council. p. 112-153.

VESIC, A. S. (1975). Bearing Capacity of Shallow Foundations. In: WINTERKORN, H. F.; FANG, H. Y. (eds.). Foundation engineering handbook. New York: Ed. Van Nostrand Reinhold Co. Cap. 3, p. 121-147.

VILAR, O. M. (1979). Estudo da compressão unidirecional do sedimento moderno (solo superficial) da cidade de São Carlos. Dissertação de Mestrado. Escola de Engenharia de São Carlos. Universidade de São Paulo. 110 p. 
APÊNDICE A 


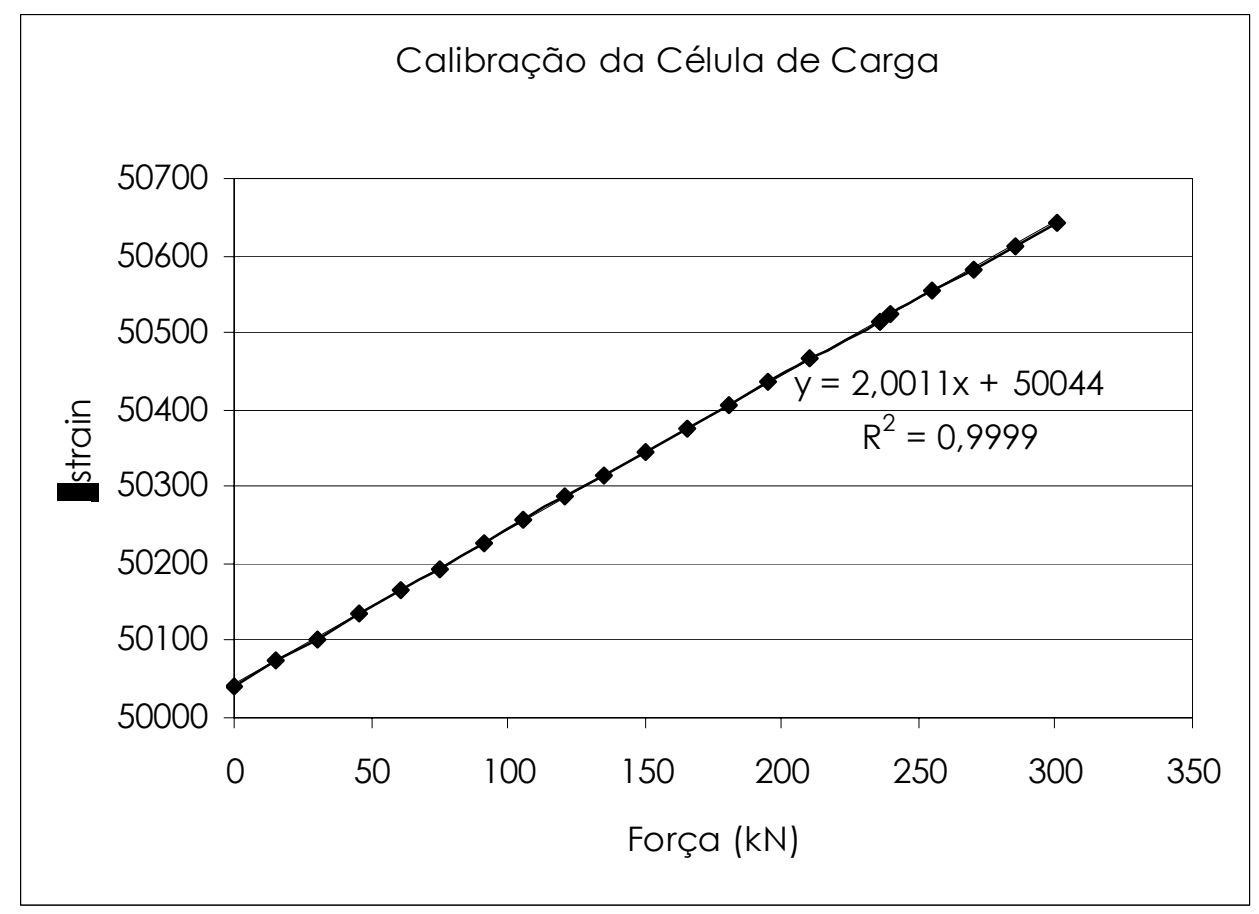

Figura A.1 - Calibração da célula de carga 
APÊNDICE B 


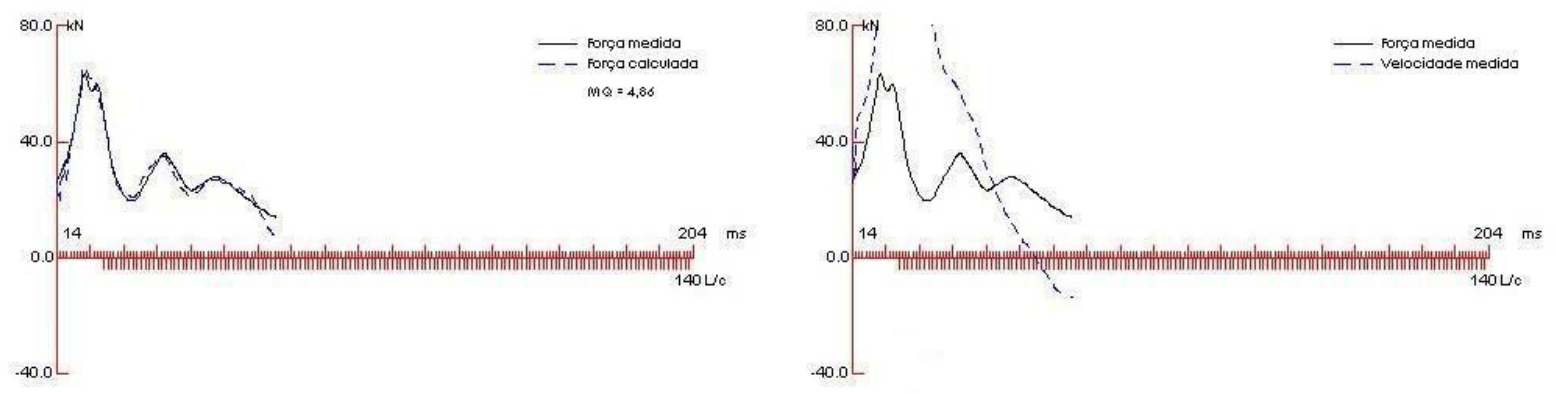

Figura B.1 - Curvas de força medida e calculada, e força e velocidade medidas, cava 1, golpe 1
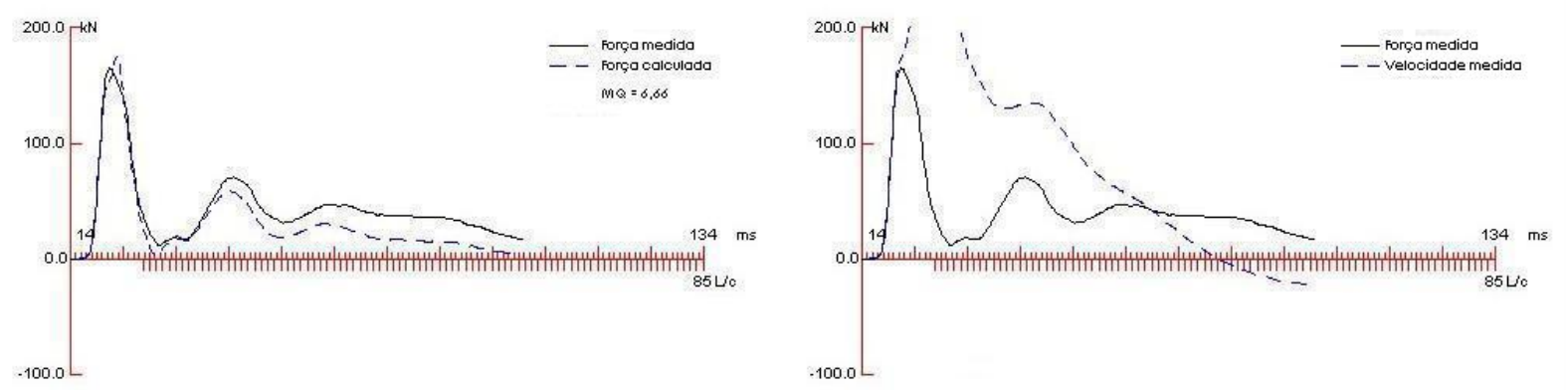

Figura B.2 - Curvas de força medida e calculada, e força e velocidade medidas, cava 1, golpe 2
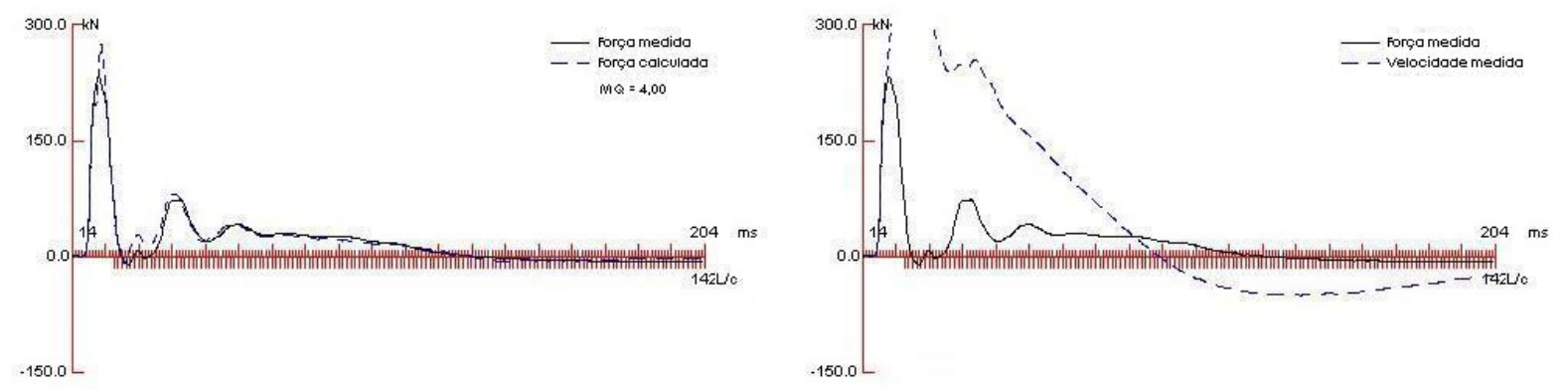

Figura B.3 - Curvas de força medida e calculada, e força e velocidade medidas, cava 1, golpe 3 

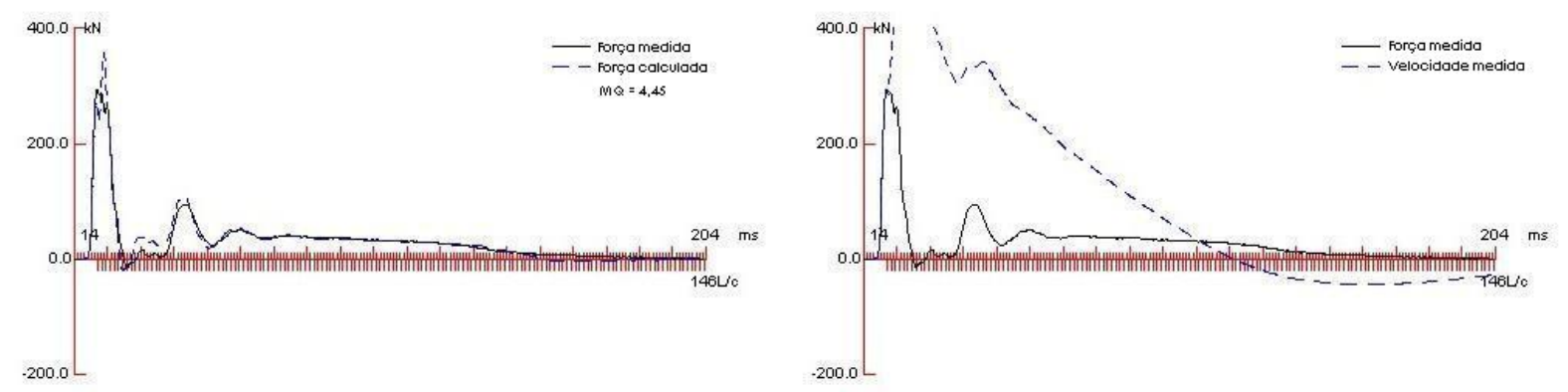

Figura B.4 - Curvas de força medida e calculada, e força e velocidade medidas, cava 1, golpe 4
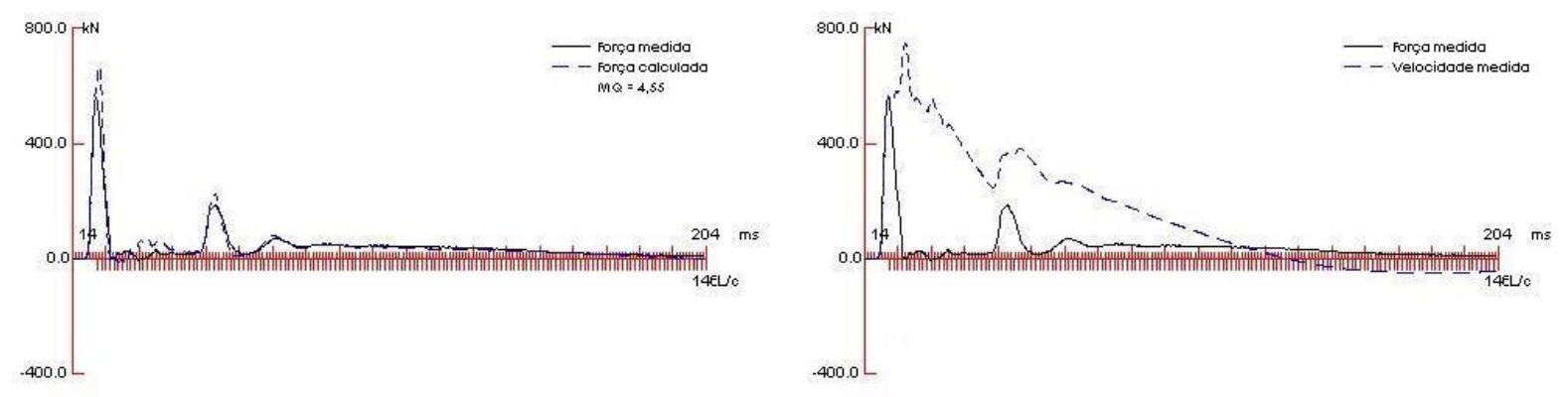

Figura B.5 - Curvas de força medida e calculada, e força e velocidade medidas, cava 1, golpe 5
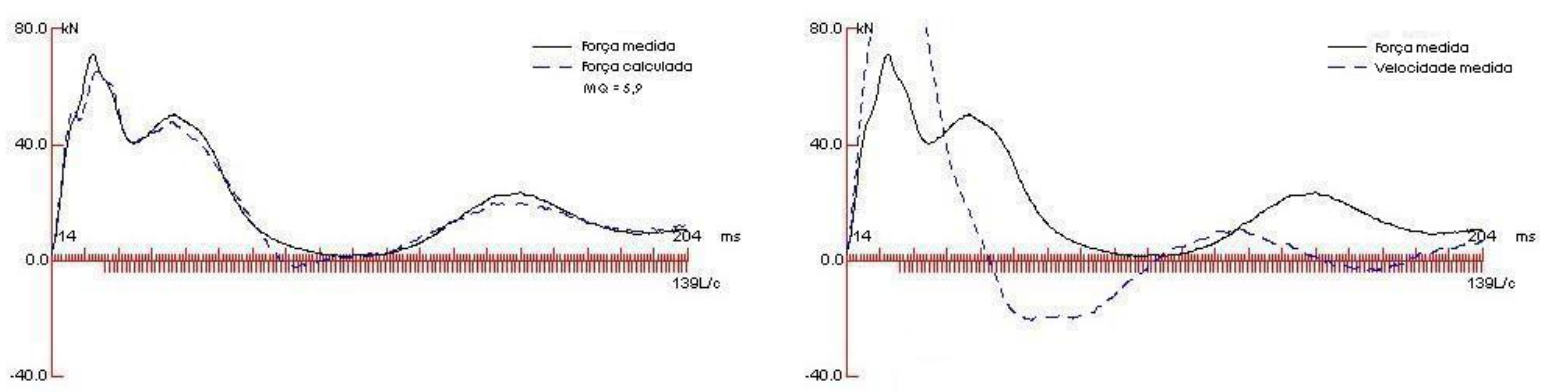

Figura B.6 - Curvas de força medida e calculada, e força e velocidade medidas, cava 3, golpe 1 

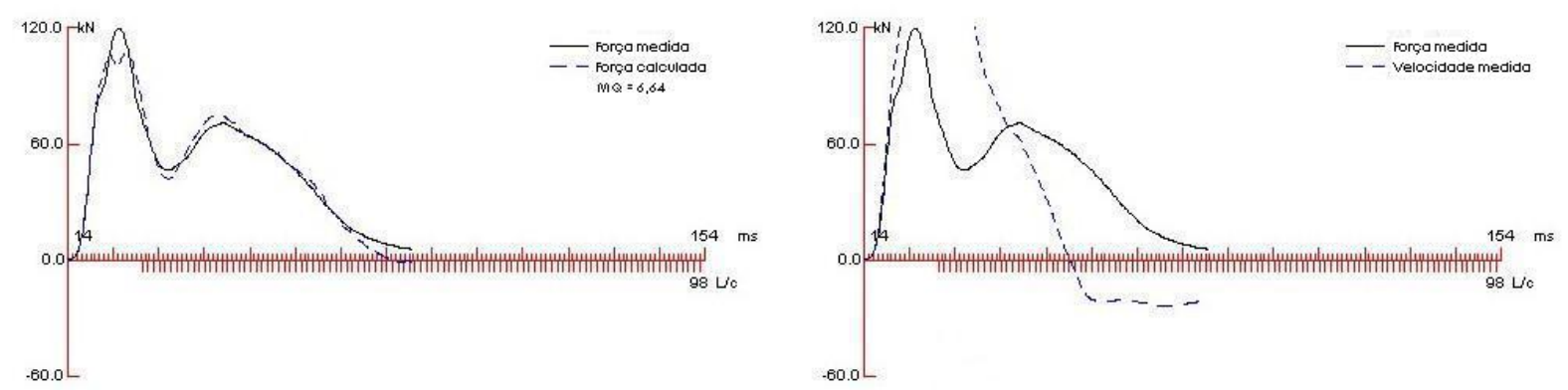

Figura B.7 - Curvas de força medida e calculada, e força e velocidade medidas, cava 3, golpe 2
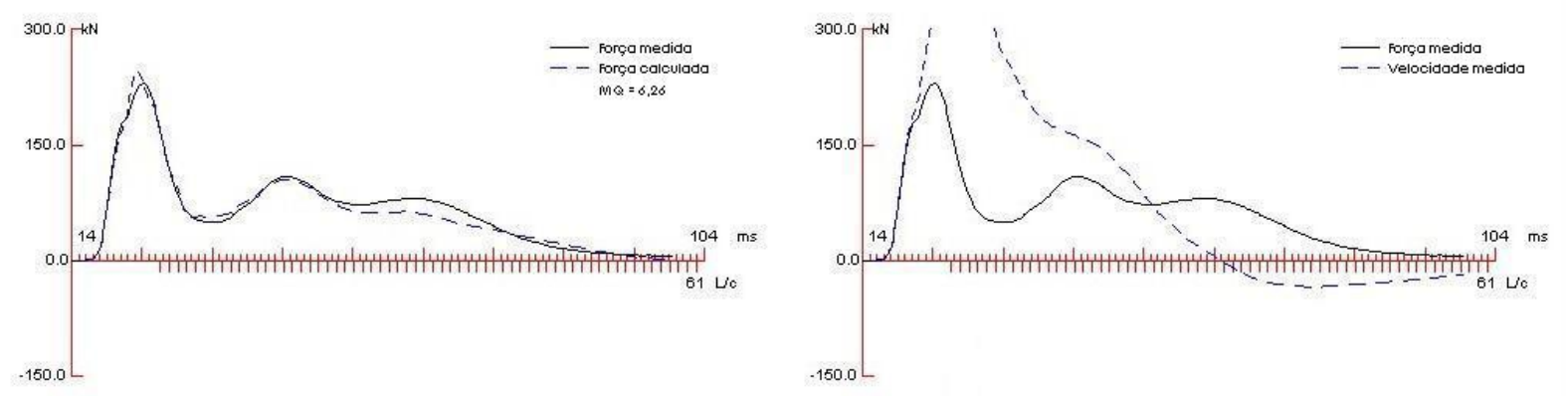

Figura B.8 - Curvas de força medida e calculada, e força e velocidade medidas, cava 3 , golpe 3
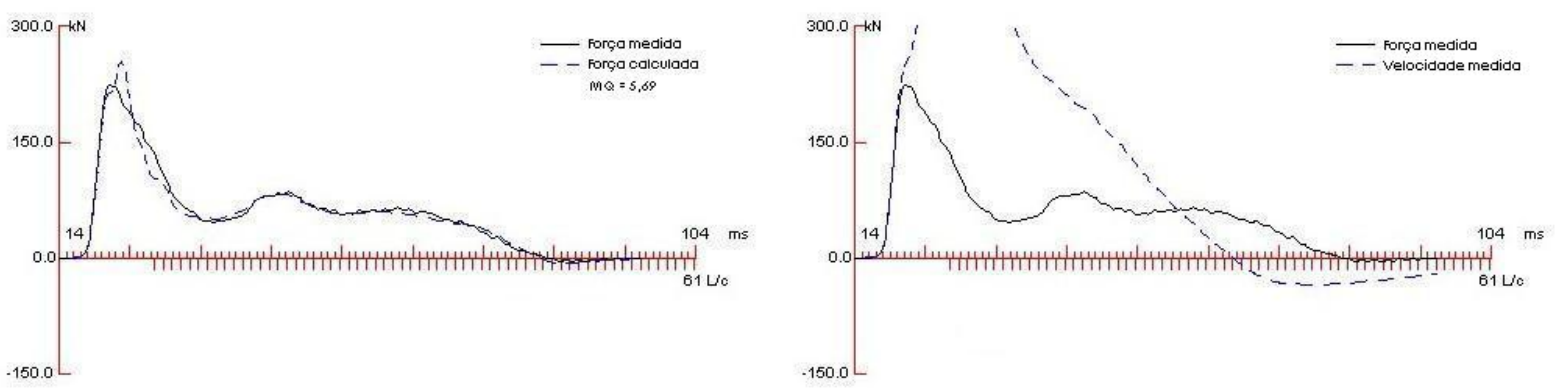

Figura B.9 - Curvas de força medida e calculada, e força e velocidade medidas, cava 3, golpe 4 

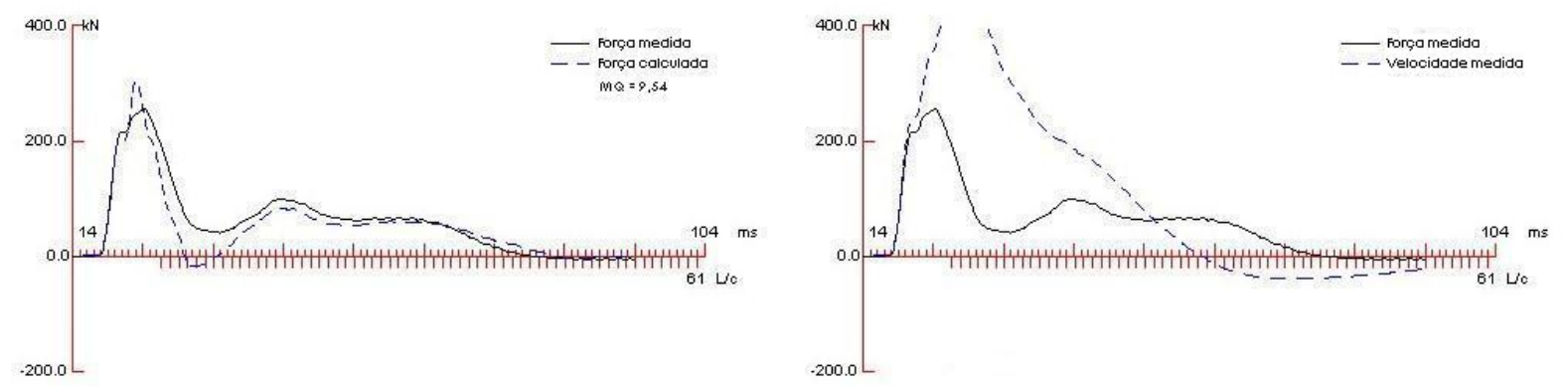

Figura B.10 - Curvas de força medida e calculada, e força e velocidade medidas, cava 3 , golpe 5
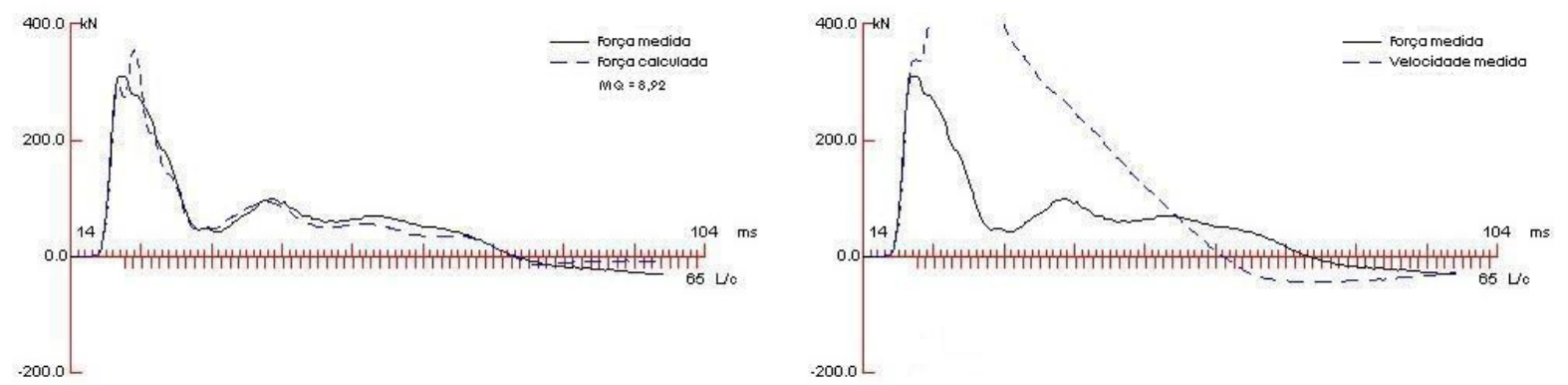

Figura B.1 1 - Curvas de força medida e calculada, e força e velocidade medidas, cava 3, golpe 6
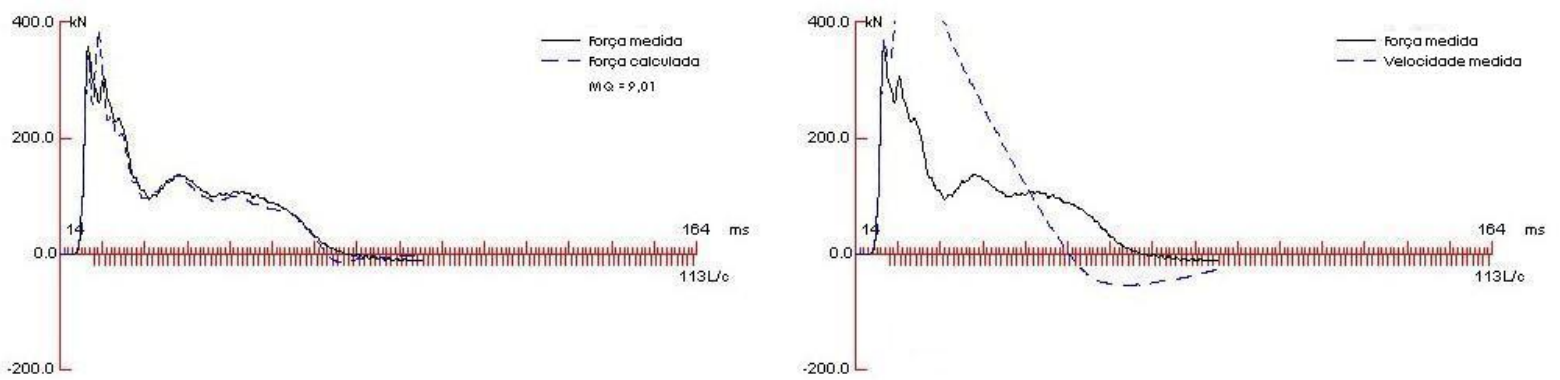

Figura B.12 - Curvas de força medida e calculada, e força e velocidade medidas, cava 3 , golpe 7 

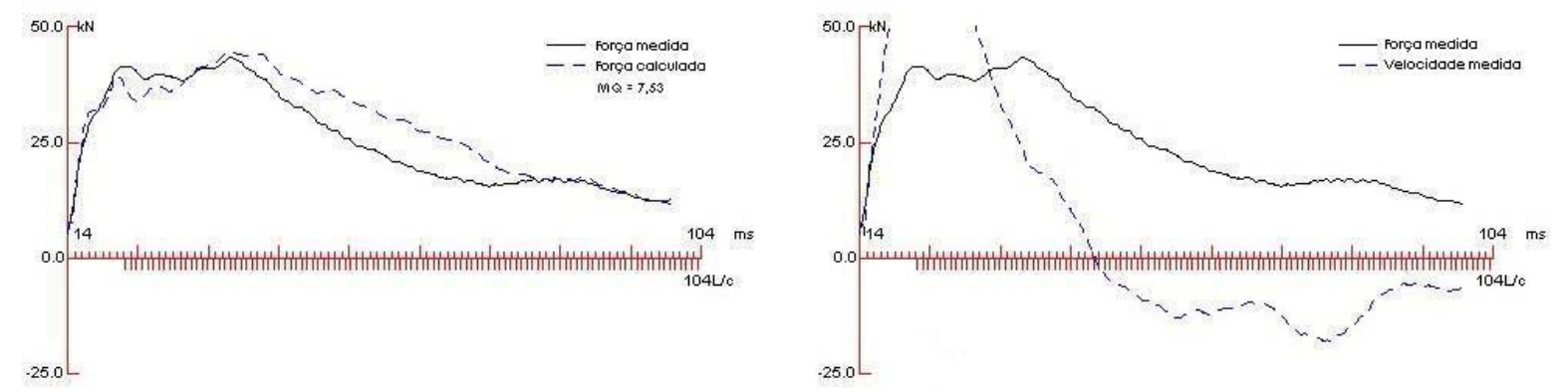

Figura B.13 - Curvas de força medida e calculada, e força e velocidade medidas, cava 4 , golpe 1
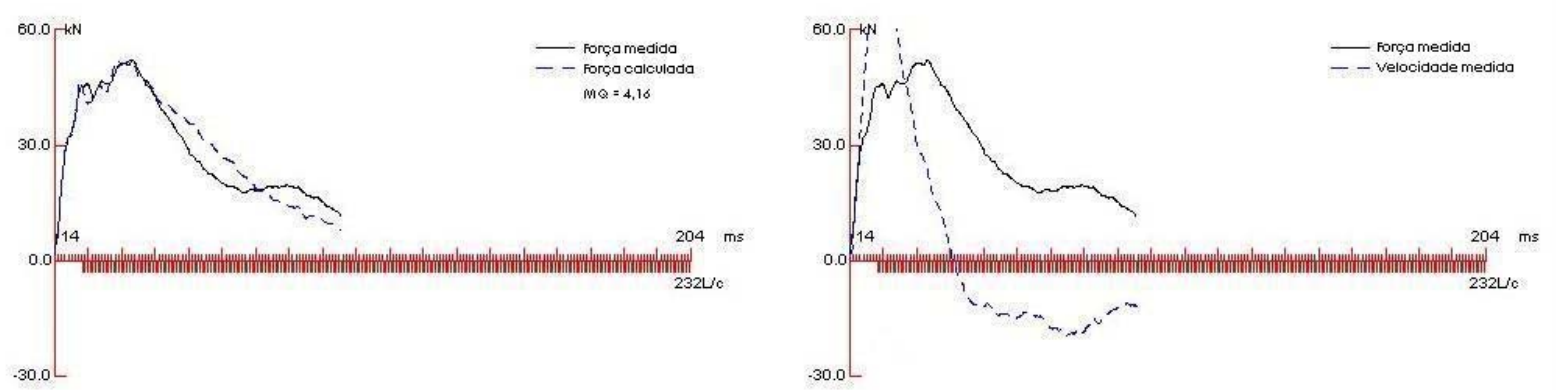

Figura B.14 - Curvas de força medida e calculada, e força e velocidade medidas, cava 4, golpe 2
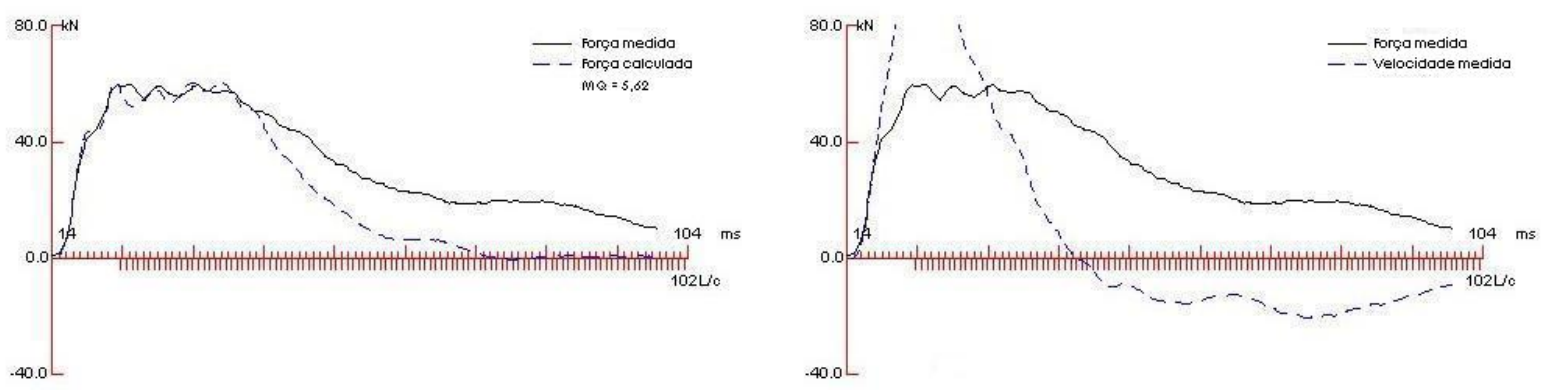

Figura B.15 - Curvas de força medida e calculada, e força e velocidade medidas, cava 4 , golpe 3 

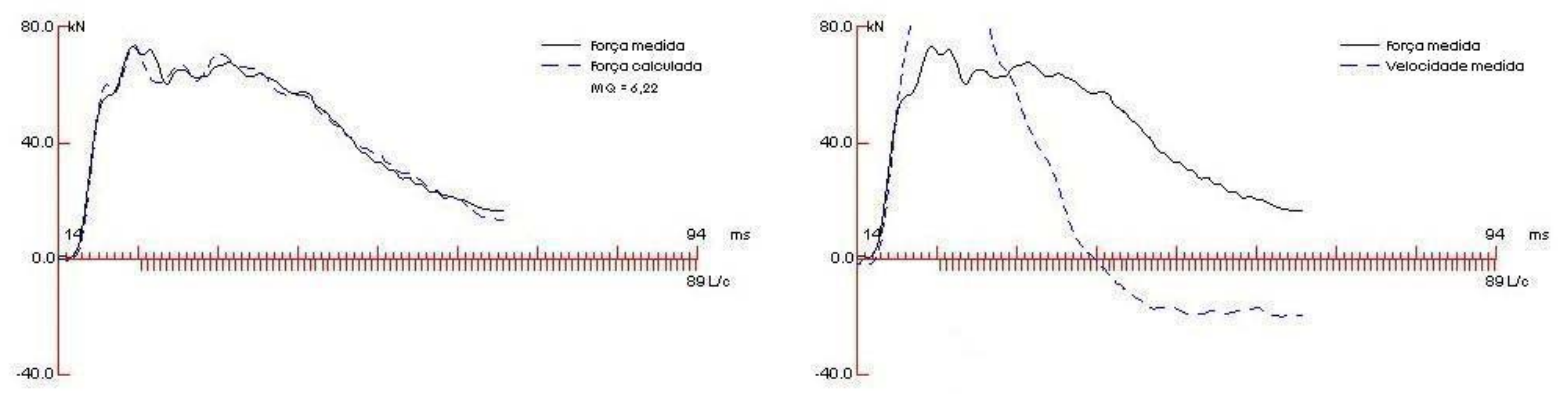

Figura B.16 - Curvas de força medida e calculada, e força e velocidade medidas, cava 4 , golpe 4
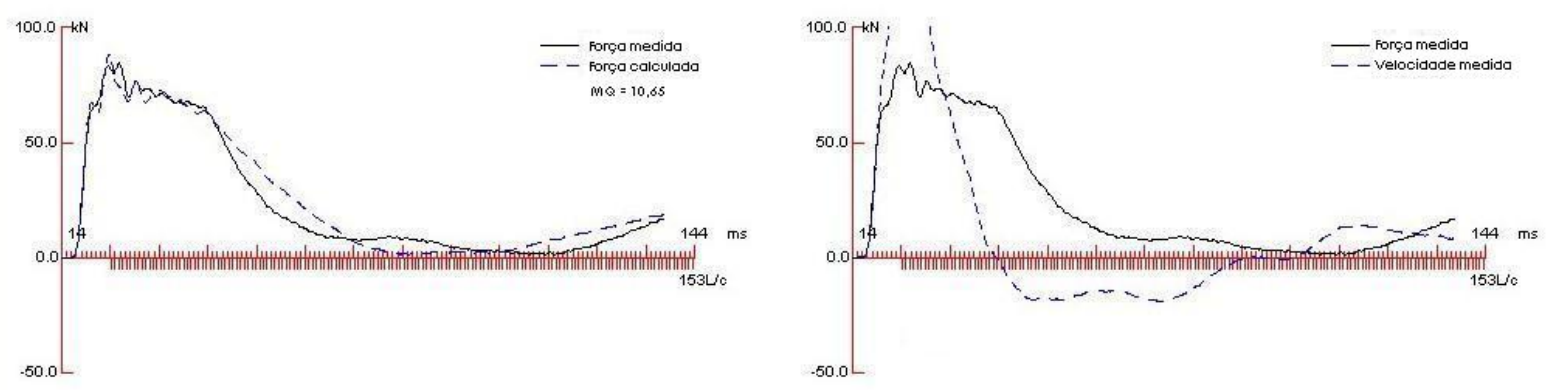

Figura B.17 - Curvas de força medida e calculada, e força e velocidade medidas, cava 4 , golpe 5
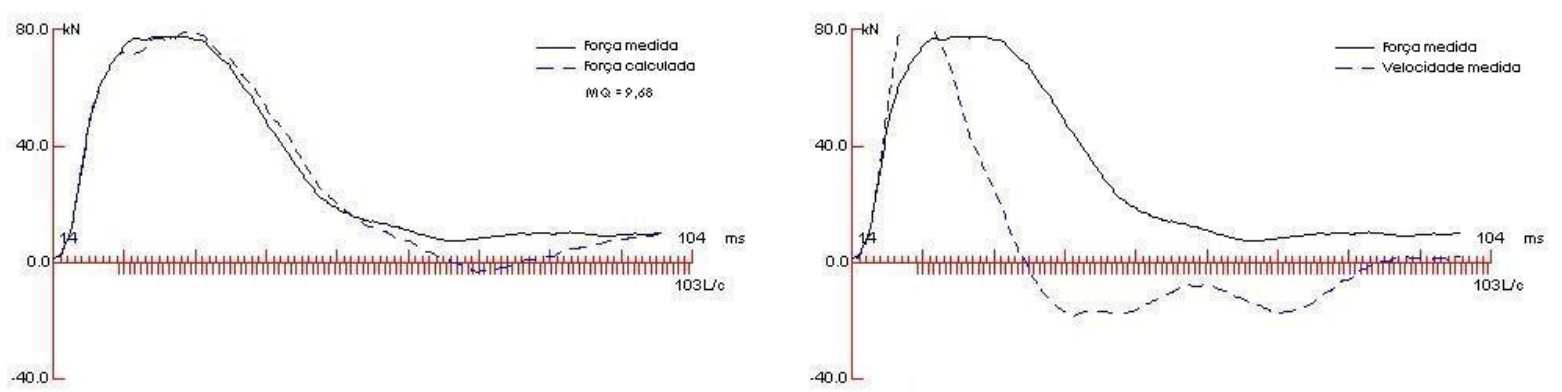

Figura B.18 - Curvas de força medida e calculada, e força e velocidade medidas, cava 4 , golpe 6 

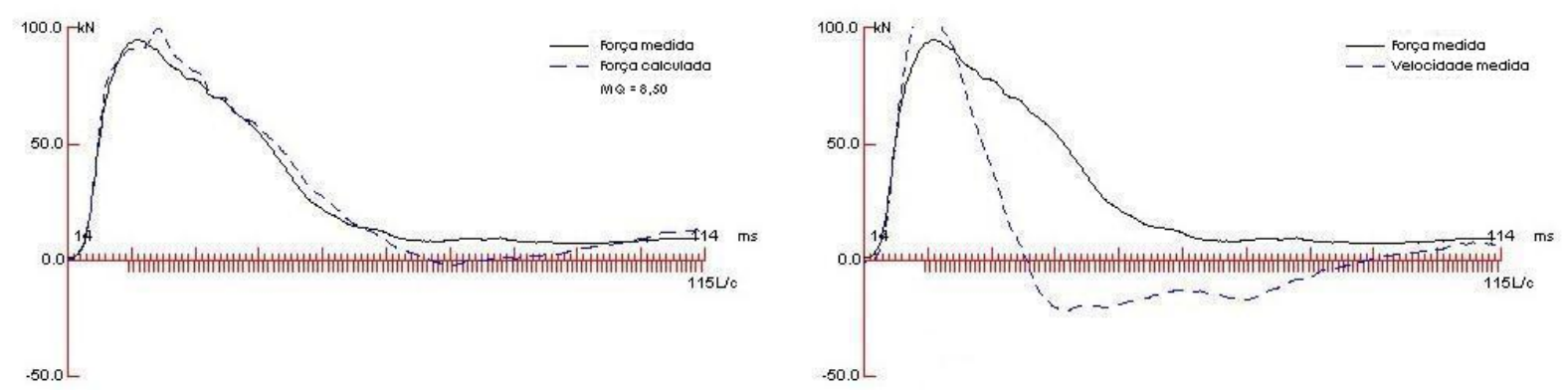

Figura B.19 - Curvas de força medida e calculada, e força e velocidade medidas, cava 4, golpe 7
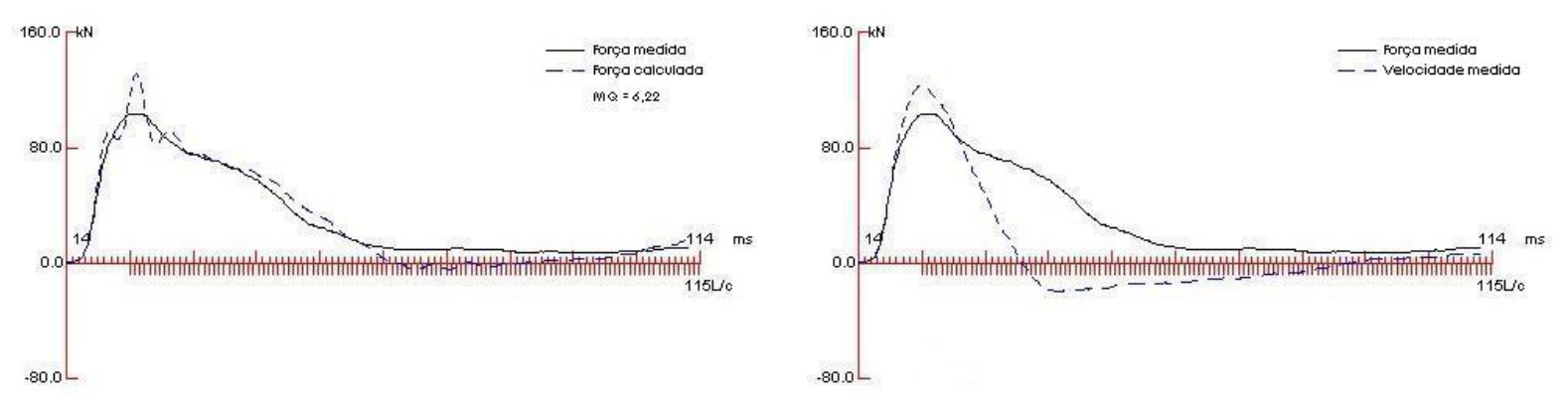

Figura B.20 - Curvas de força medida e calculada, e força e velocidade medidas, cava 4 , golpe 8
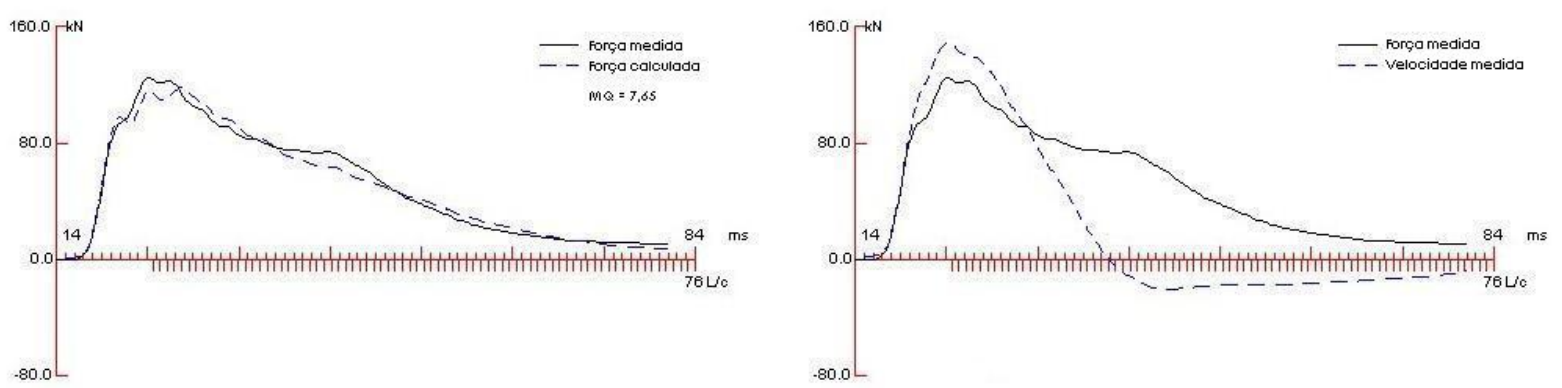

Figura B.21 - Curvas de força medida e calculada, e força e velocidade medidas, cava 4, golpe 9 

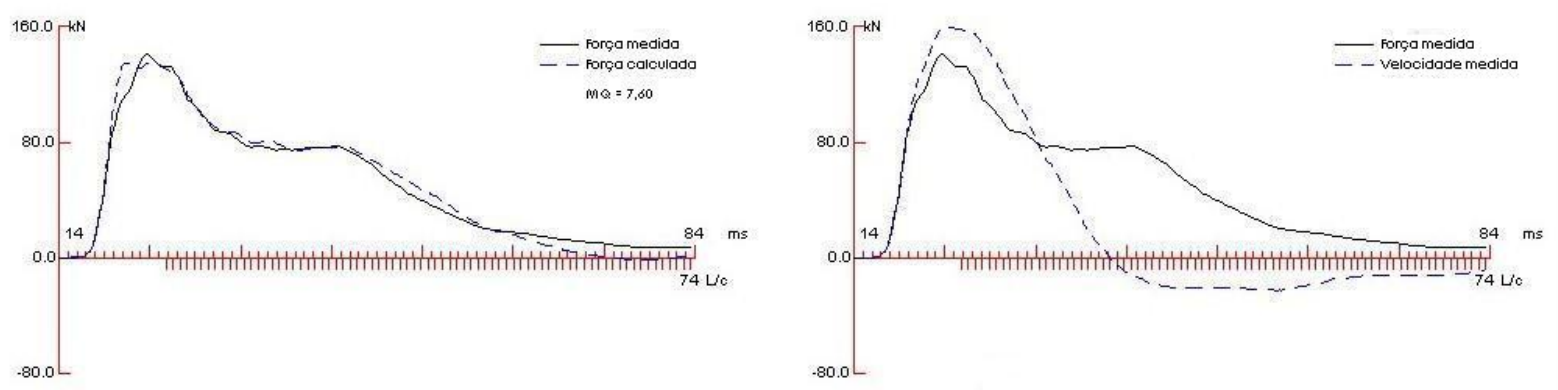

Figura B.22 - Curvas de força medida e calculada, e força e velocidade medidas, cava 4 , golpe 10
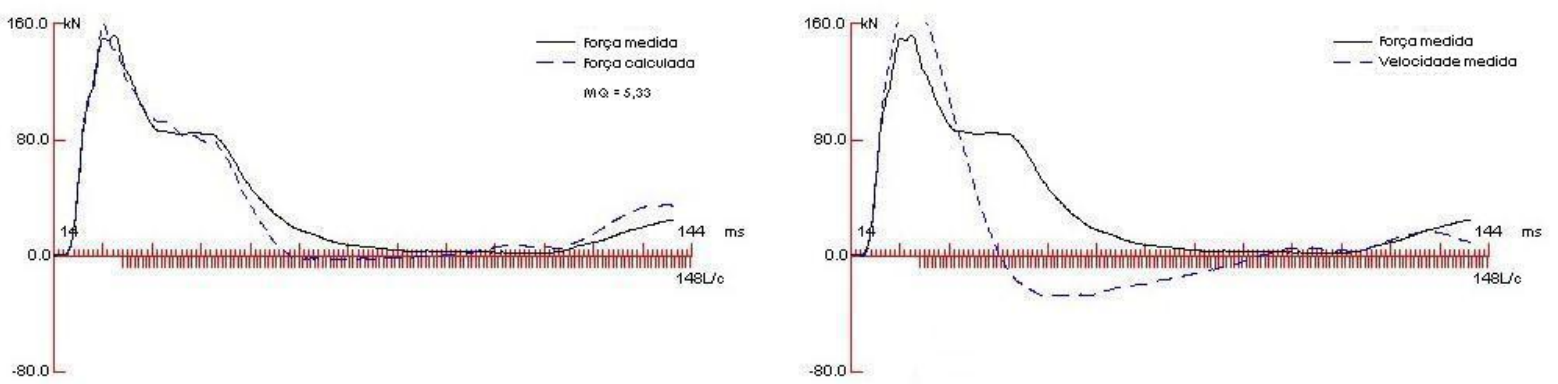

Figura B.23 - Curvas de força medida e calculada, e força e velocidade medidas, cava 4 , golpe 11
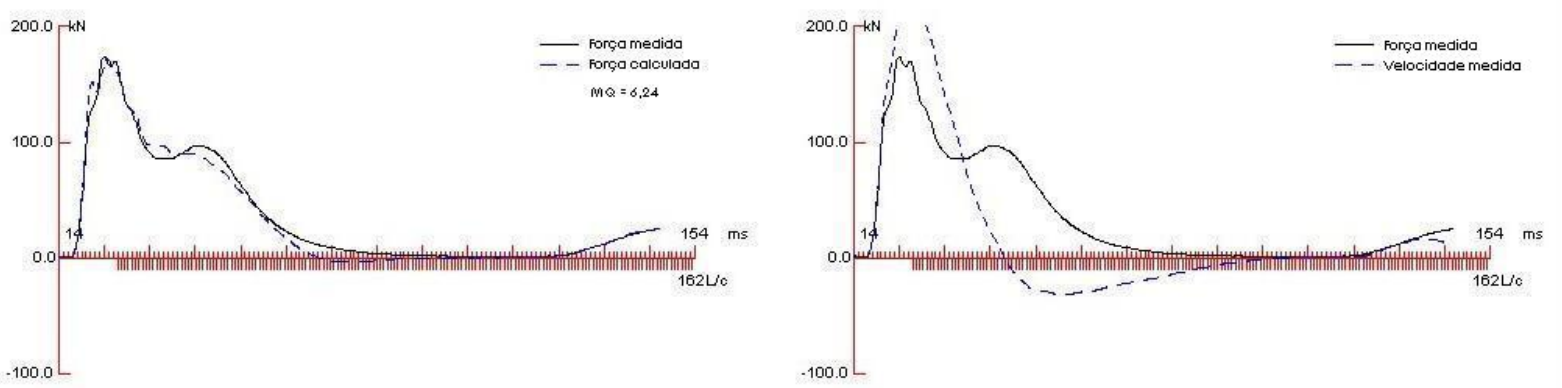

Figura B.24 - Curvas de força medida e calculada, e força e velocidade medidas, cava 4, golpe 12 

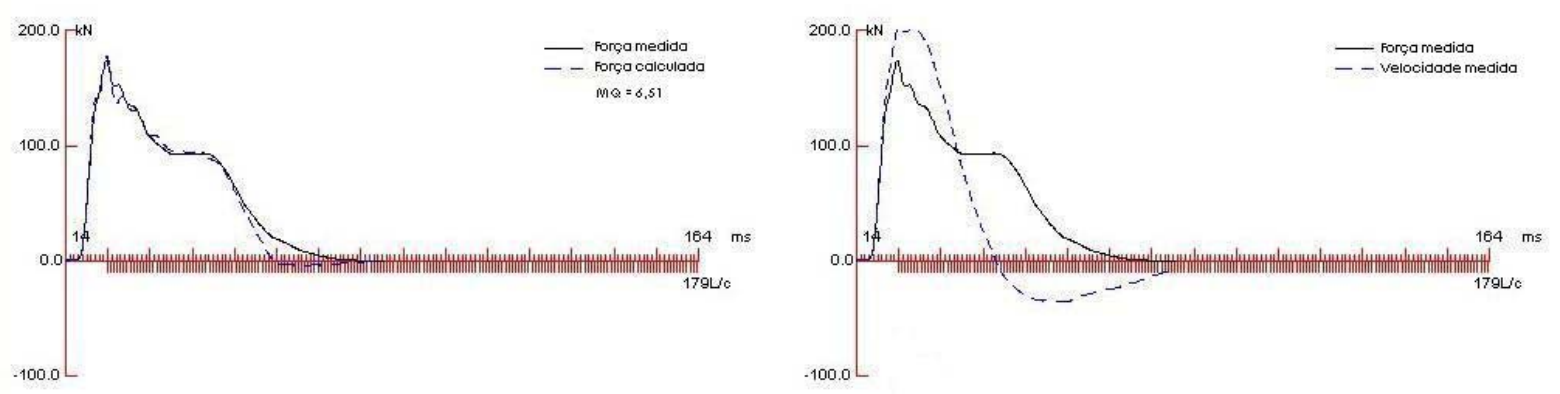

Figura B.25 - Curvas de força medida e calculada, e força e velocidade medidas, cava 4, golpe 13
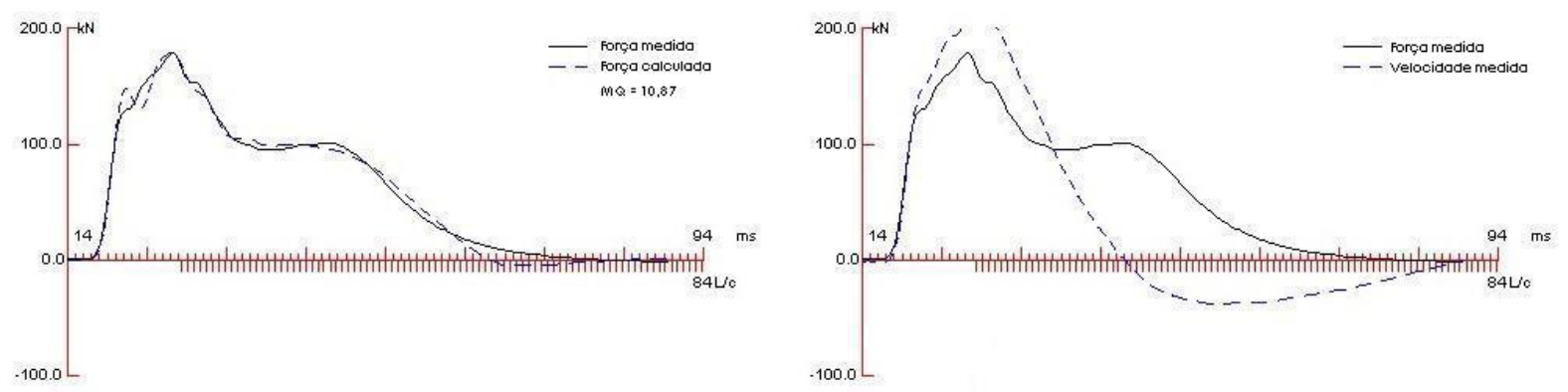

Figura B.26 - Curvas de força medida e calculada, e força e velocidade medidas, cava 4 , golpe 14
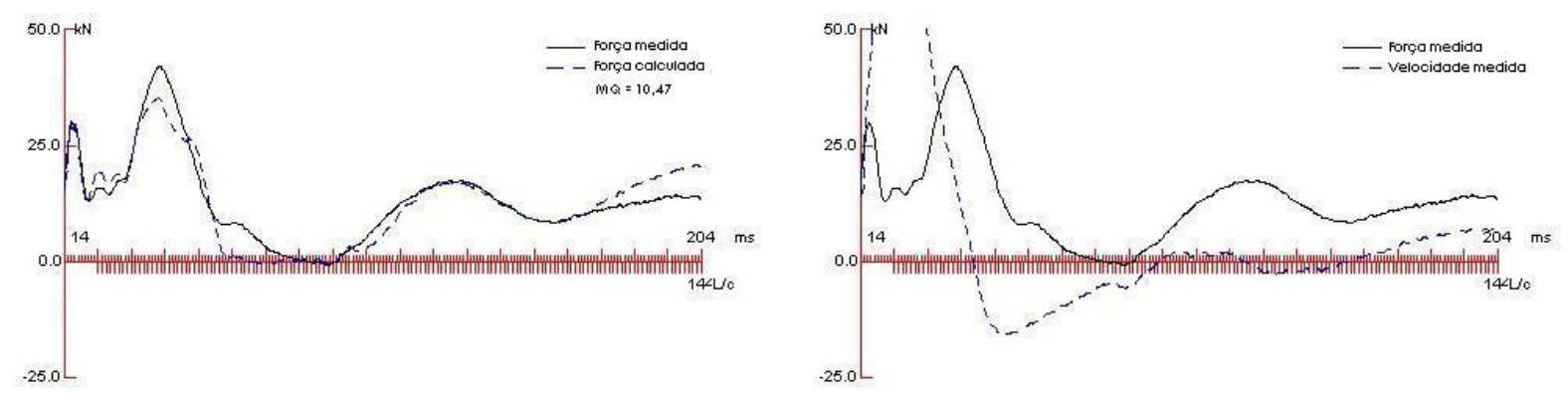

Figura B.27 - Curvas de força medida e calculada, e força e velocidade medidas, cava 6, golpe 1 

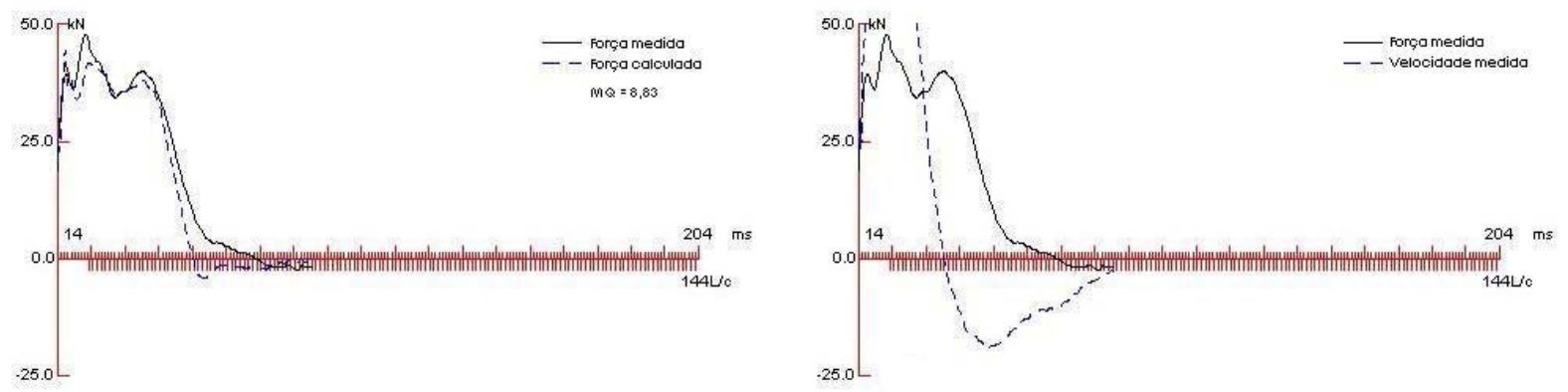

Figura B.28 - Curvas de força medida e calculada, e força e velocidade medidas, cava 6 , golpe 2
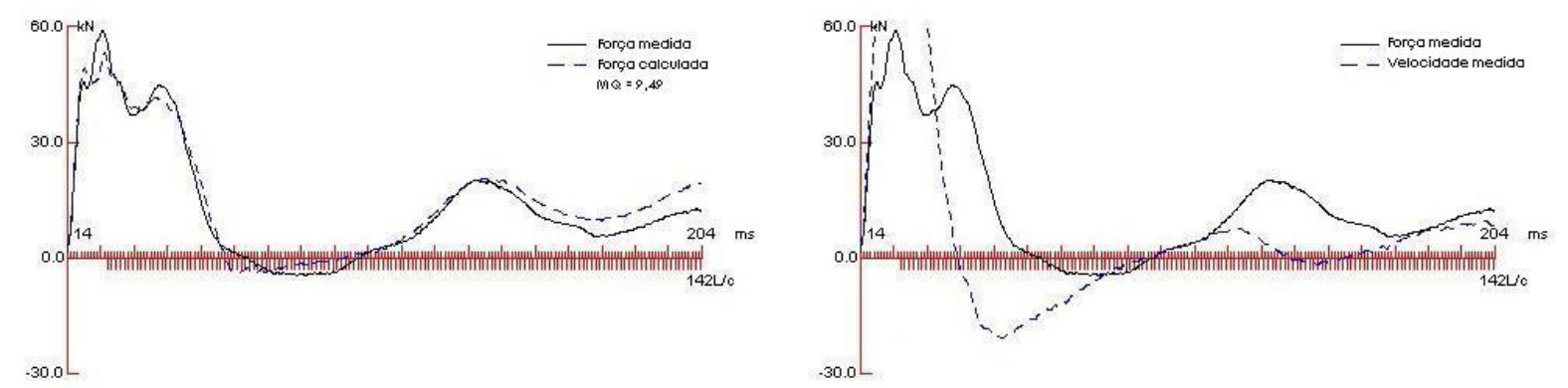

Figura B.29 - Curvas de força medida e calculada, e força e velocidade medidas, cava 6 , golpe 3
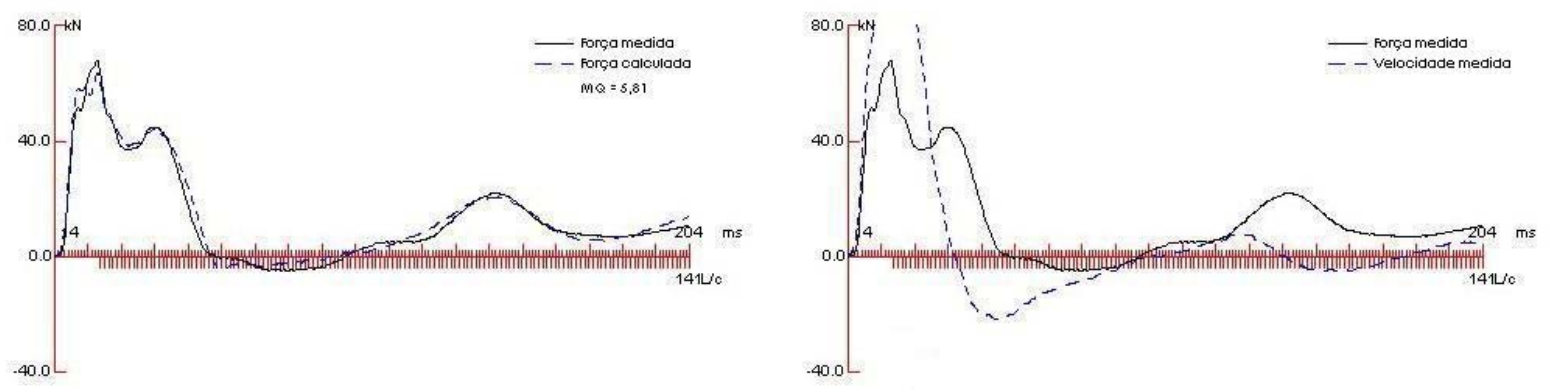

Figura B.30 - Curvas de força medida e calculada, e força e velocidade medidas, cava 6 , golpe 4 
131
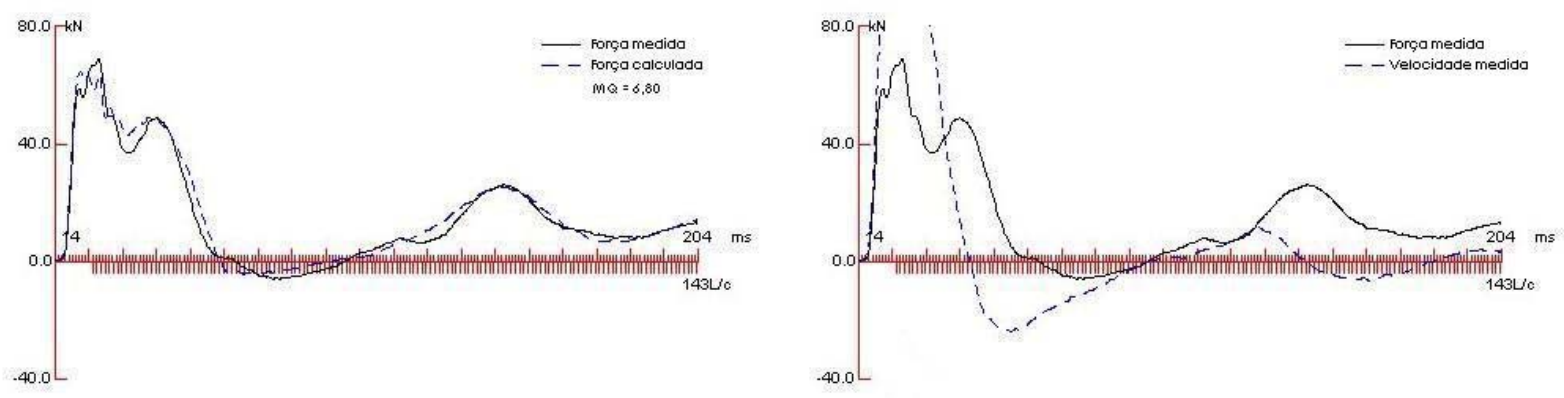

Figura B.31 - Curvas de força medida e calculada, e força e velocidade medidas, cava 6, golpe 5
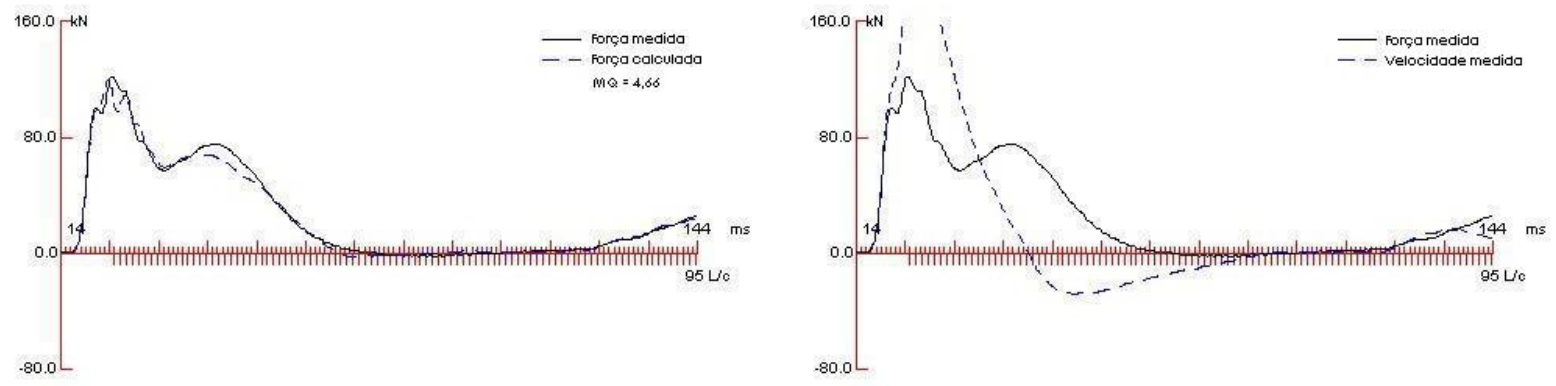

Figura B.32 - Curvas de força medida e calculada, e força e velocidade medidas, cava 6, golpe 6
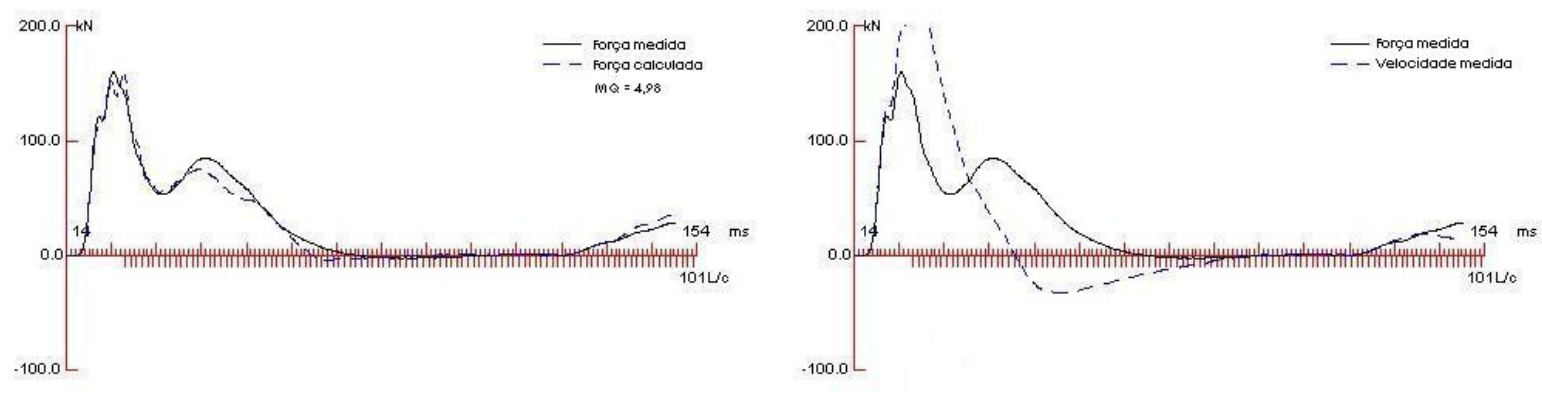

Figura B.33 - Curvas de força medida e calculada, e força e velocidade medidas, cava 6 , golpe 7 

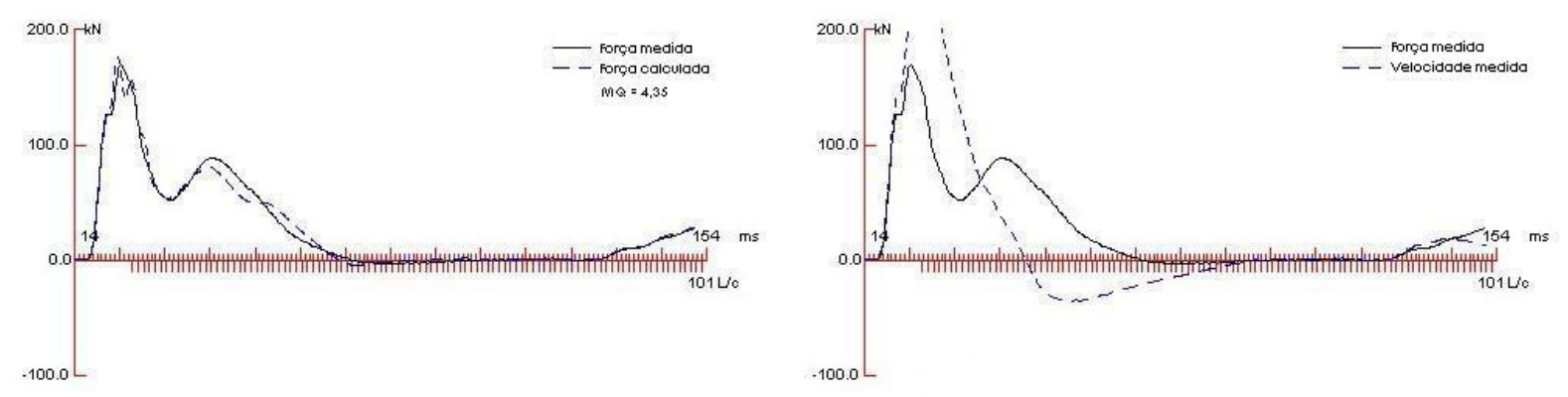

Figura B.34 - Curvas de força medida e calculada, e força e velocidade medidas, cava 6 , golpe 8
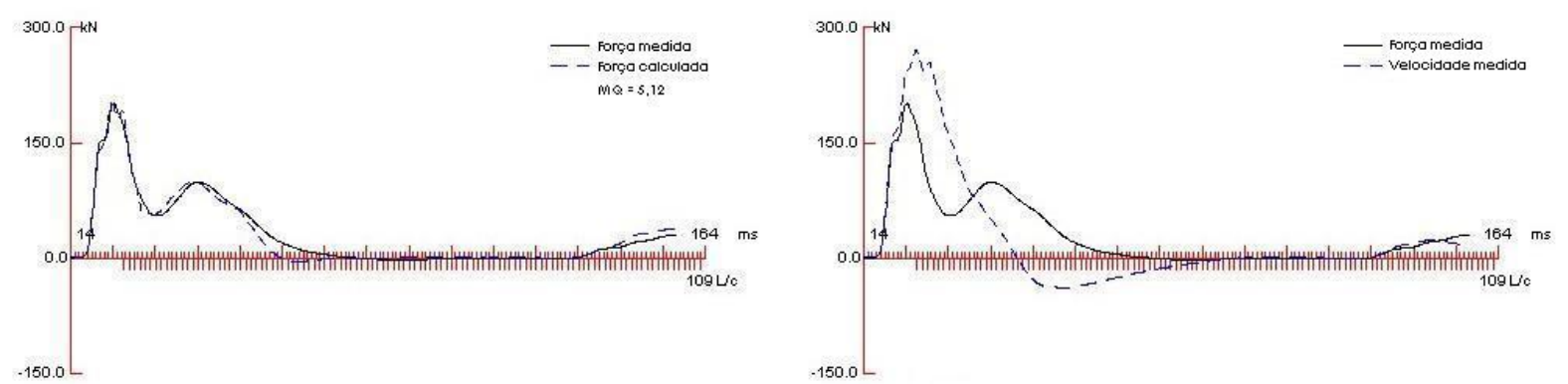

Figura B.35 - Curvas de força medida e calculada, e força e velocidade medidas, cava 6, golpe 9
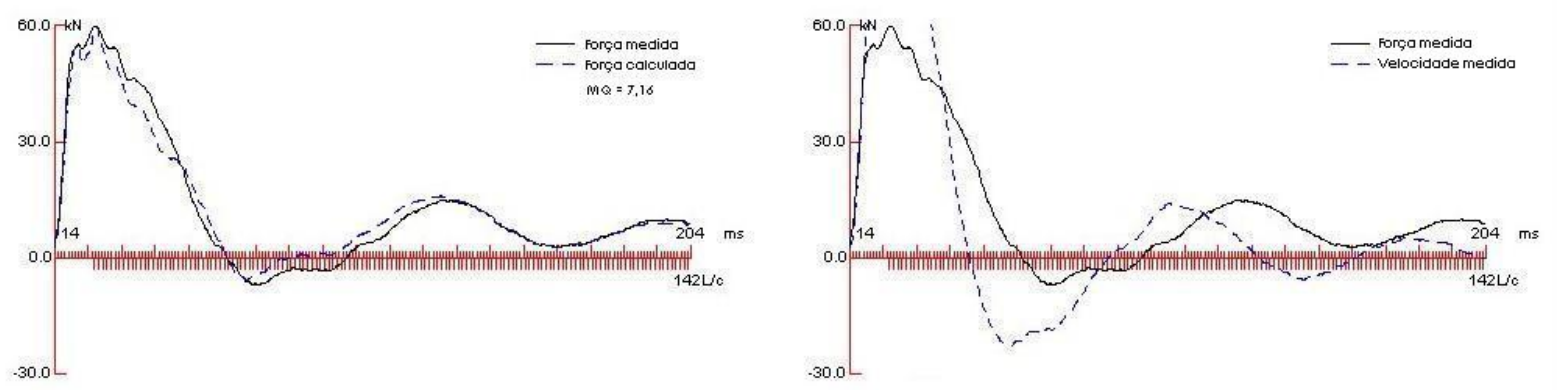

Figura B.36 - Curvas de força medida e calculada, e força e velocidade medidas, cava 6 r, golpe 1 

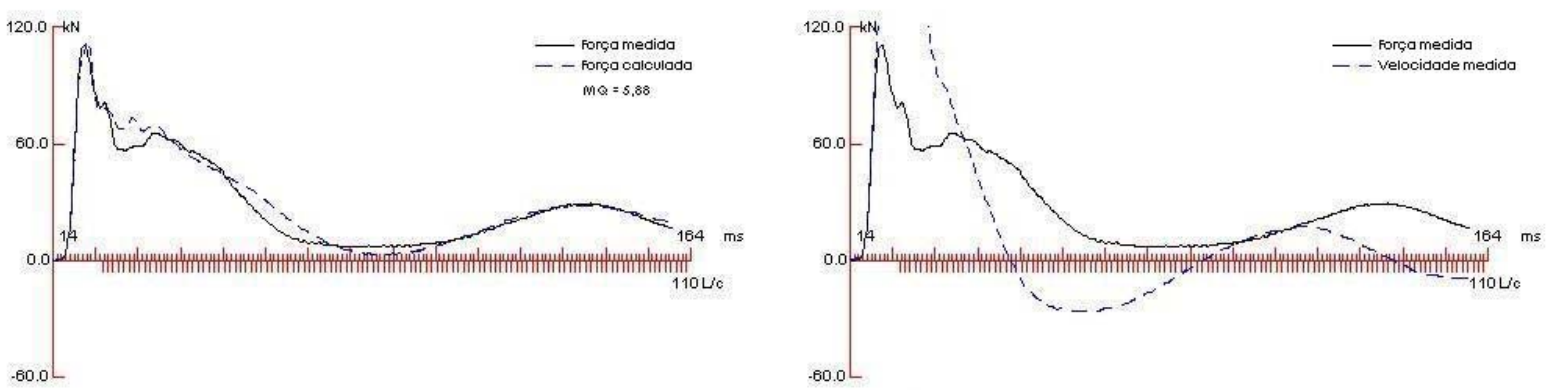

Figura B.37 - Curvas de força medida e calculada, e força e velocidade medidas, cava 6r, golpe 2
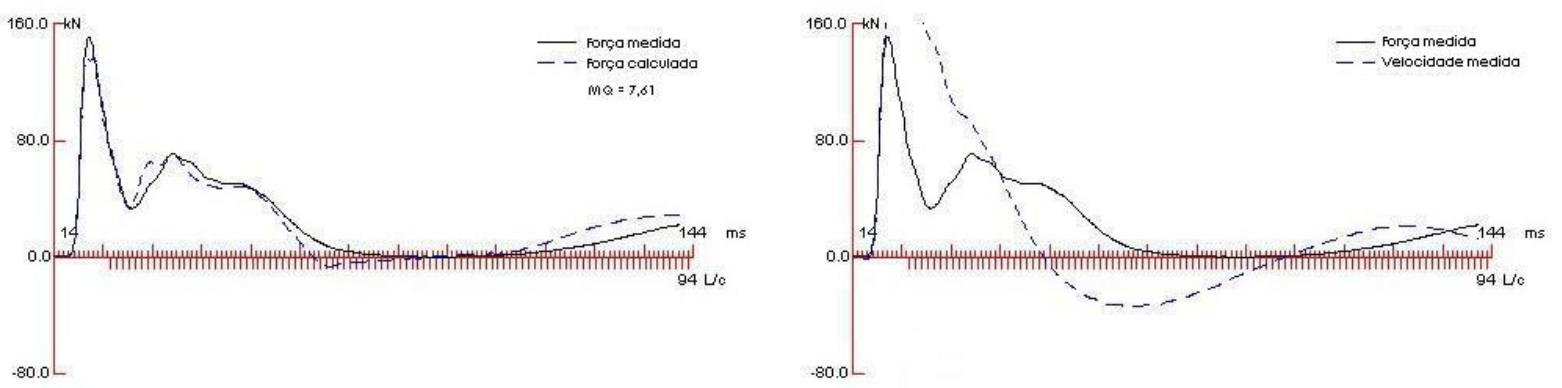

Figura B.38 - Curvas de força medida e calculada, e força e velocidade medidas, cava 6r, golpe 3
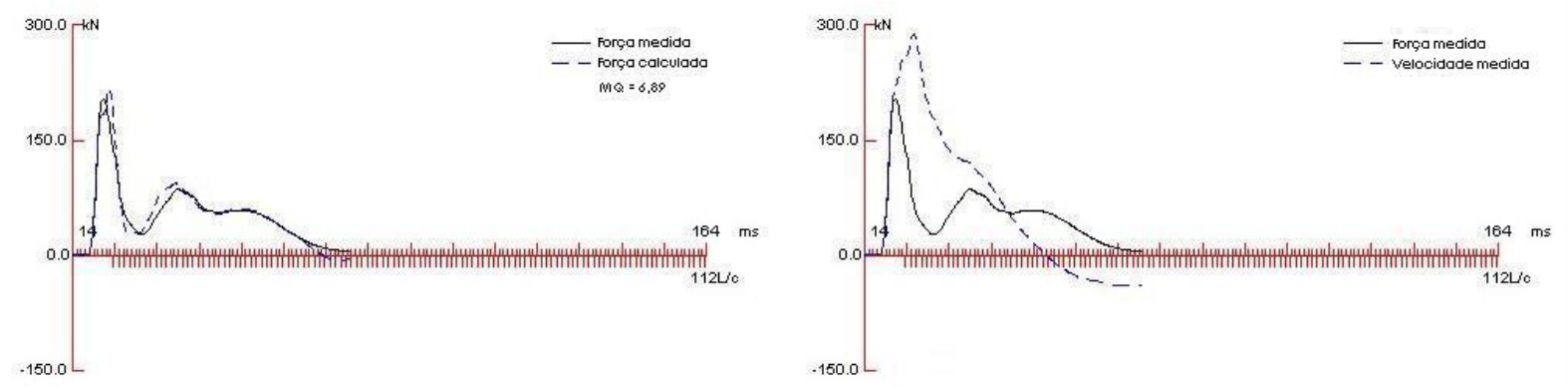

Figura B.39 - Curvas de força medida e calculada, e força e velocidade medidas, cava 6 r, golpe 4 

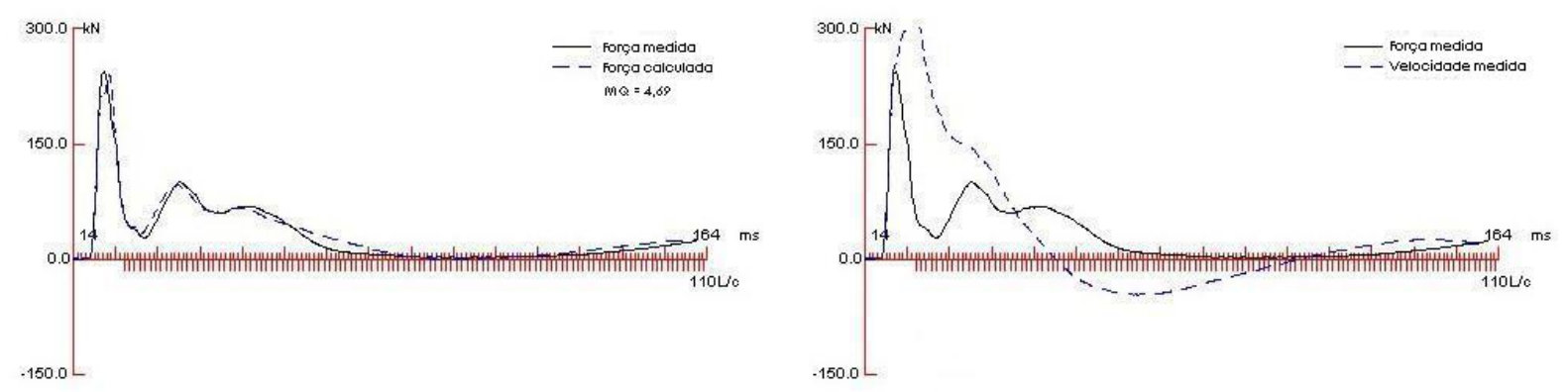

Figura B.40 - Curvas de força medida e calculada, e força e velocidade medidas, cava 6 r, golpe 5
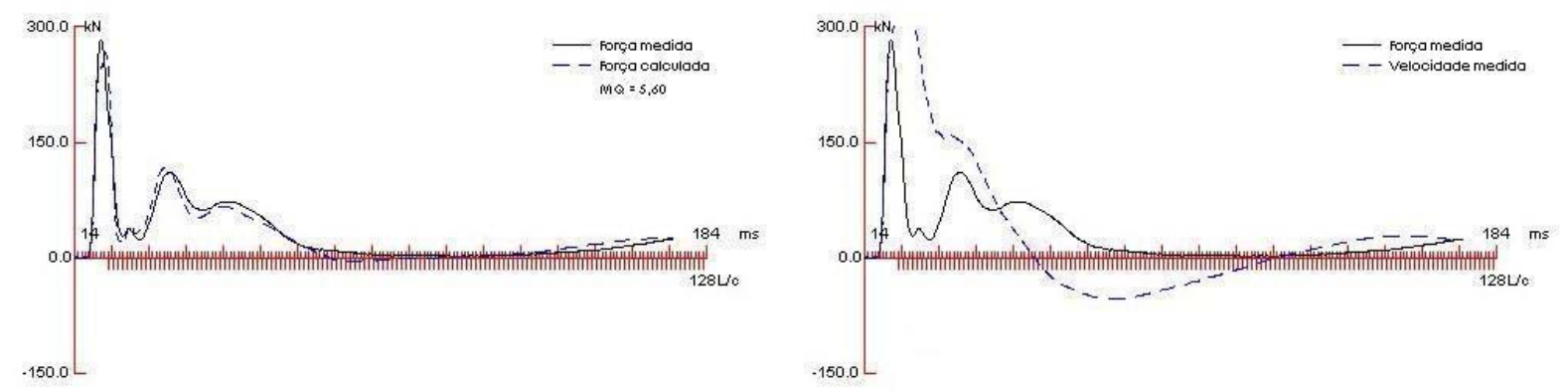

Figura B.41 - Curvas de força medida e calculada, e força e velocidade medidas, cava 6 r, golpe 6
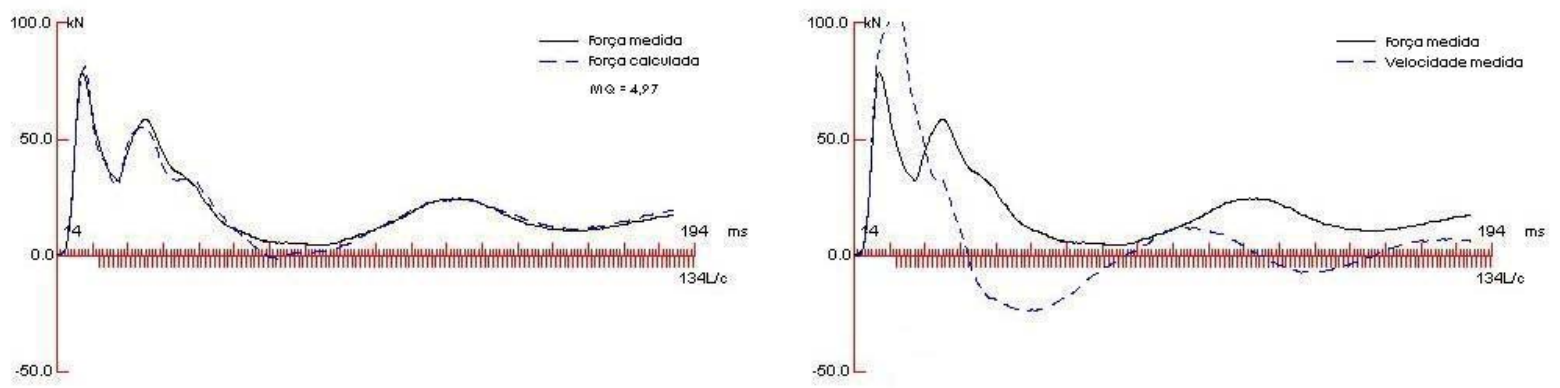

Figura B.42 - Curvas de força medida e calculada, e força e velocidade medidas, cava 7 , golpe 1 


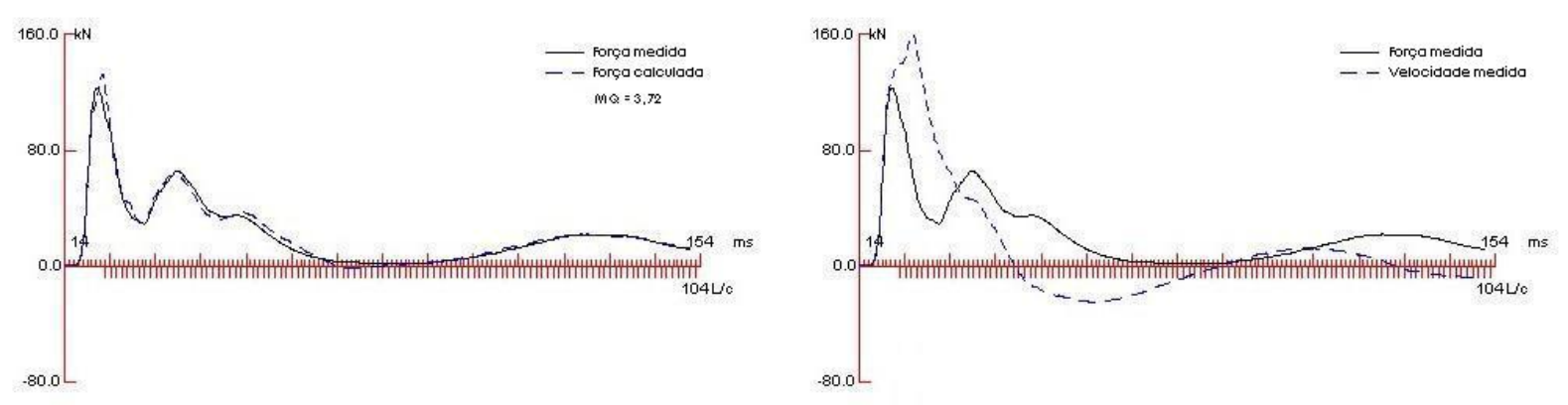

Figura B.43 - Curvas de força medida e calculada, e força e velocidade medidas, cava 7 , golpe 2
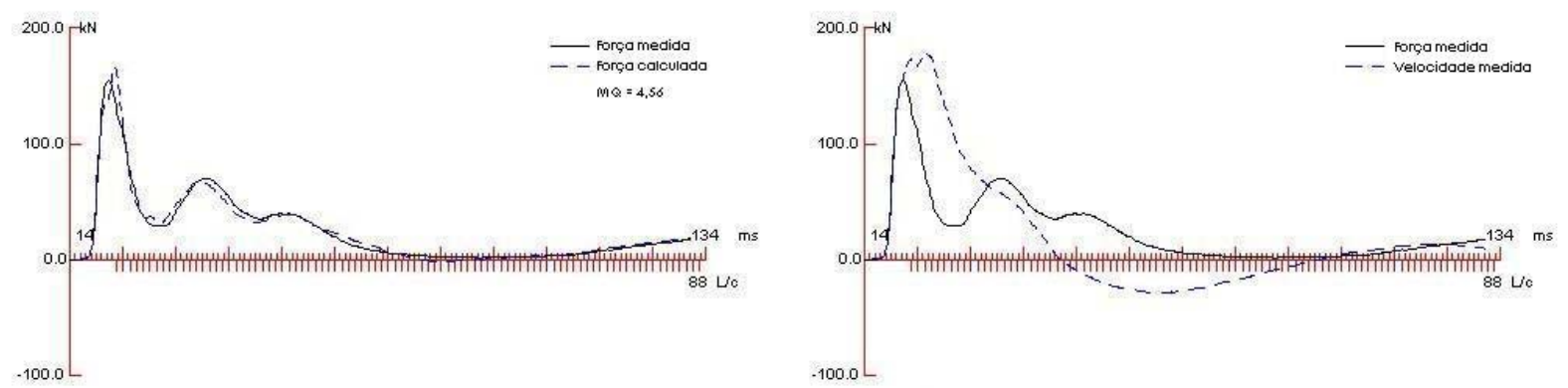

Figura B.44 - Curvas de força medida e calculada, e força e velocidade medidas, cava 7 , golpe 3
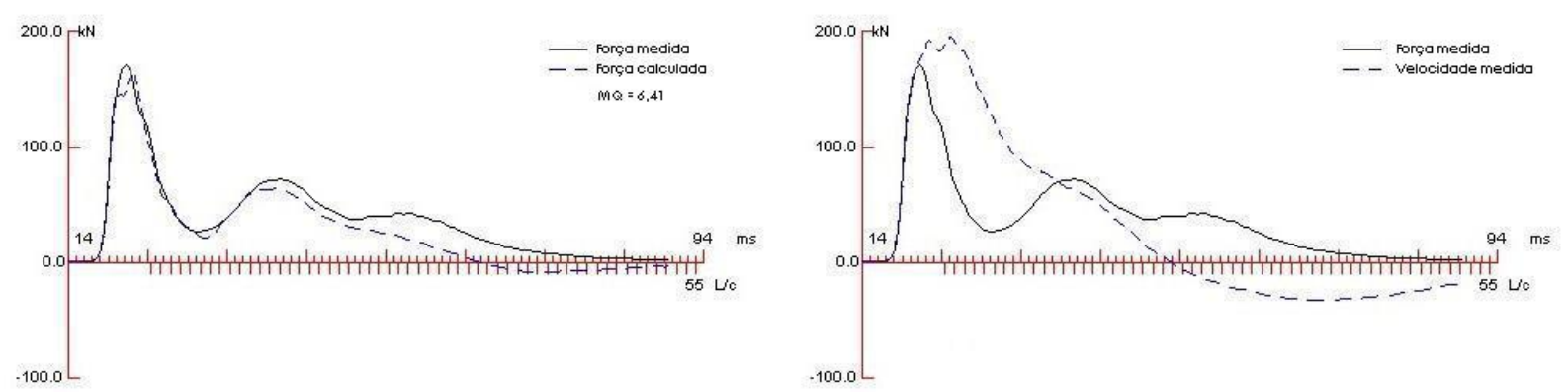

Figura B.45 - Curvas de força medida e calculada, e força e velocidade medidas, cava 7 , golpe 4 

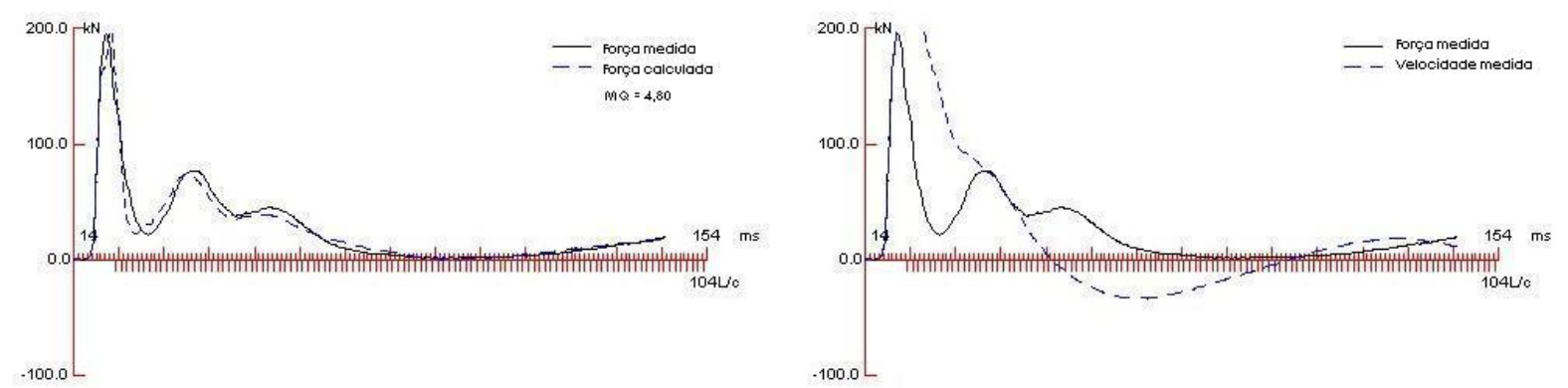

Figura B.46 - Curvas de força medida e calculada, e força e velocidade medidas, cava 7 , golpe 5
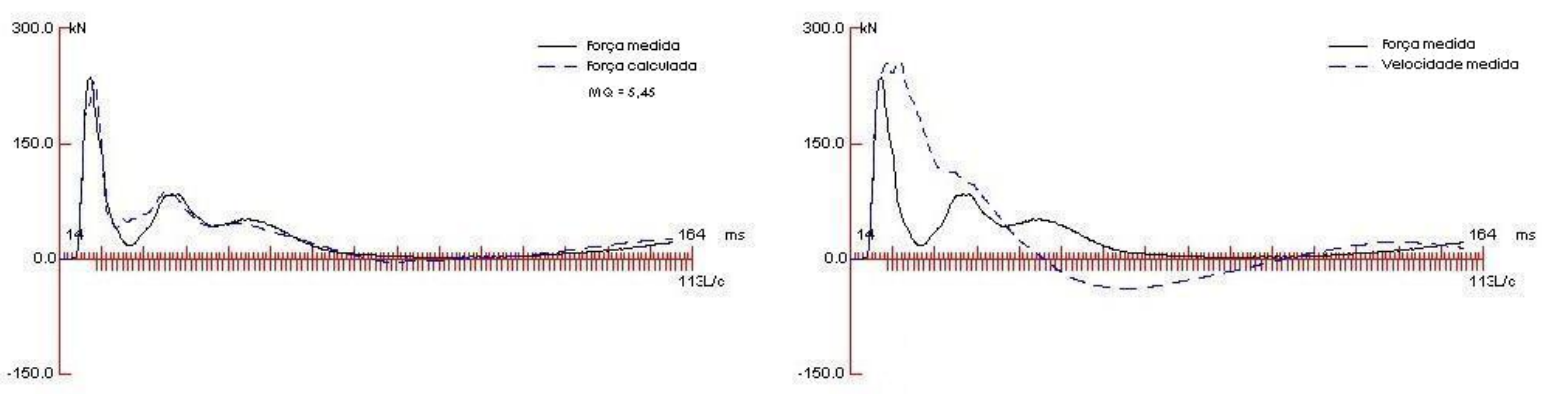

Figura B.47 - Curvas de força medida e calculada, e força e velocidade medidas, cava 7 , golpe 6
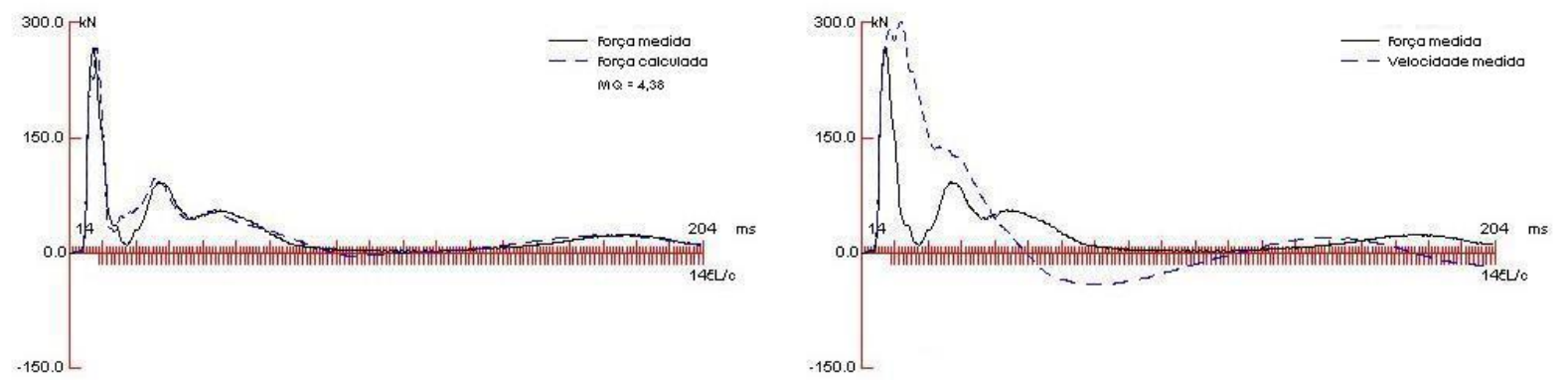

Figura B.48 - Curvas de força medida e calculada, e força e velocidade medidas, cava 7 , golpe 7 

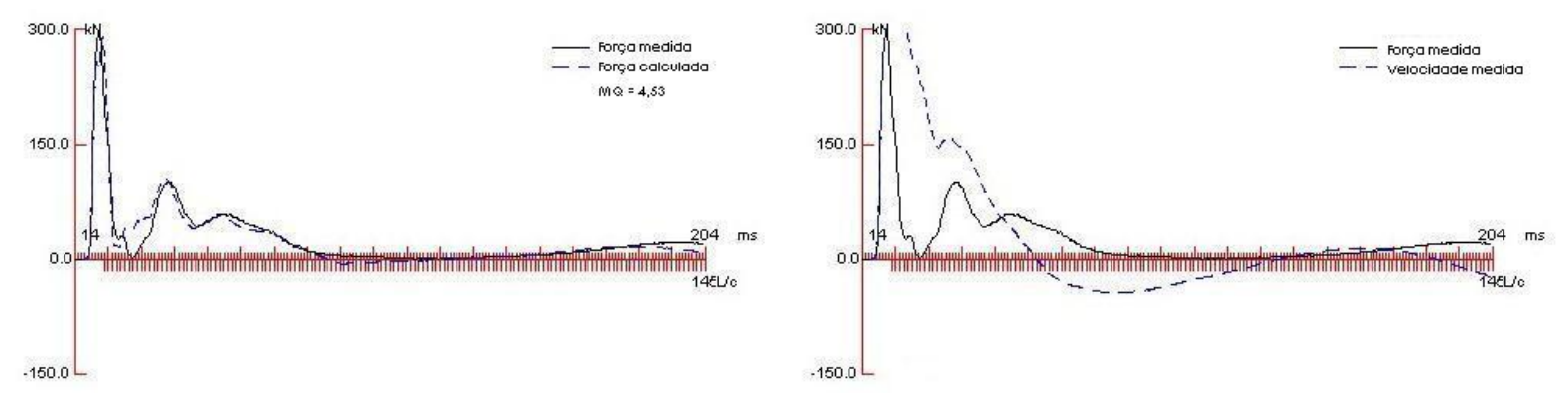

Figura B.49 - Curvas de força medida e calculada, e força e velocidade medidas, cava 7 , golpe 8
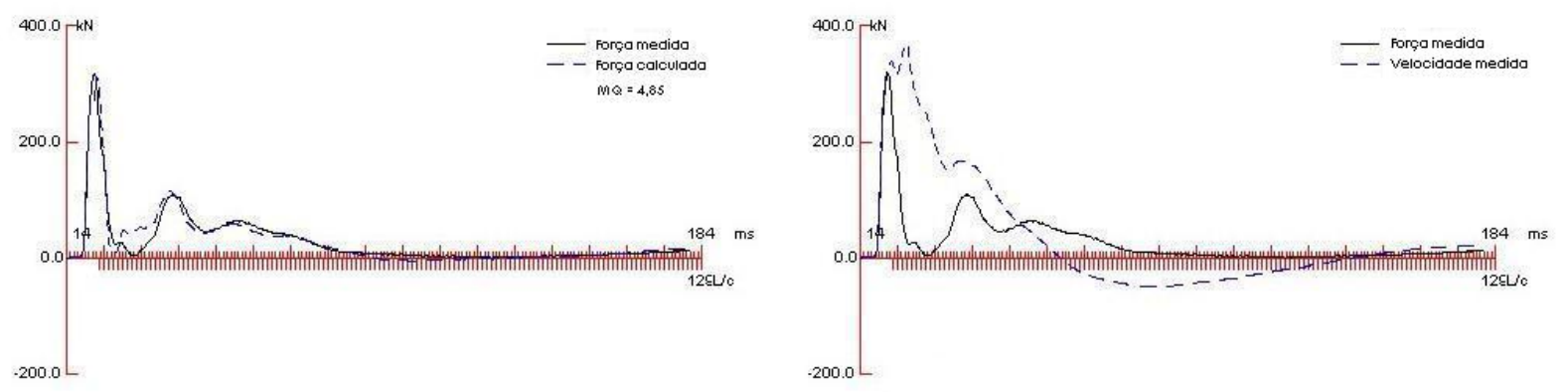

Figura B.50 - Curvas de força medida e calculada, e força e velocidade medidas, cava 7 , golpe 9
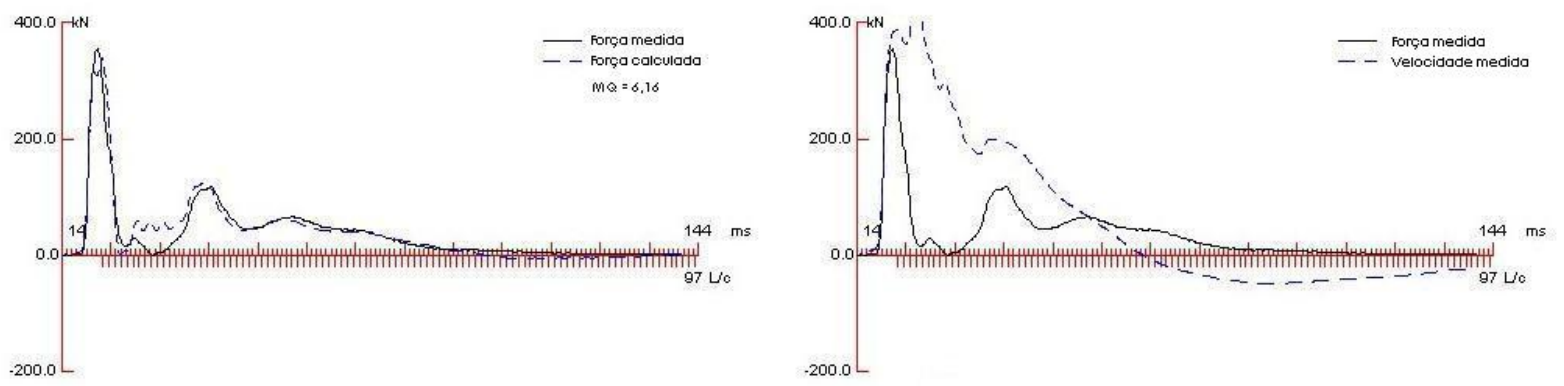

Figura B.51 - Curvas de força medida e calculada, e força e velocidade medidas, cava 7 , golpe 10 

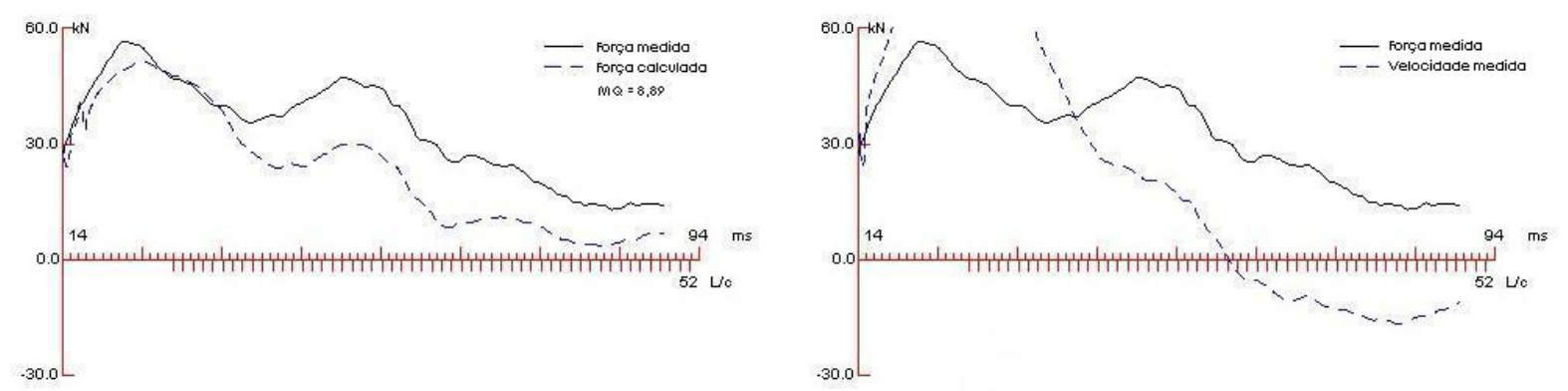

Figura B.52 - Curvas de força medida e calculada, e força e velocidade medidas, cava 8 , golpe 1
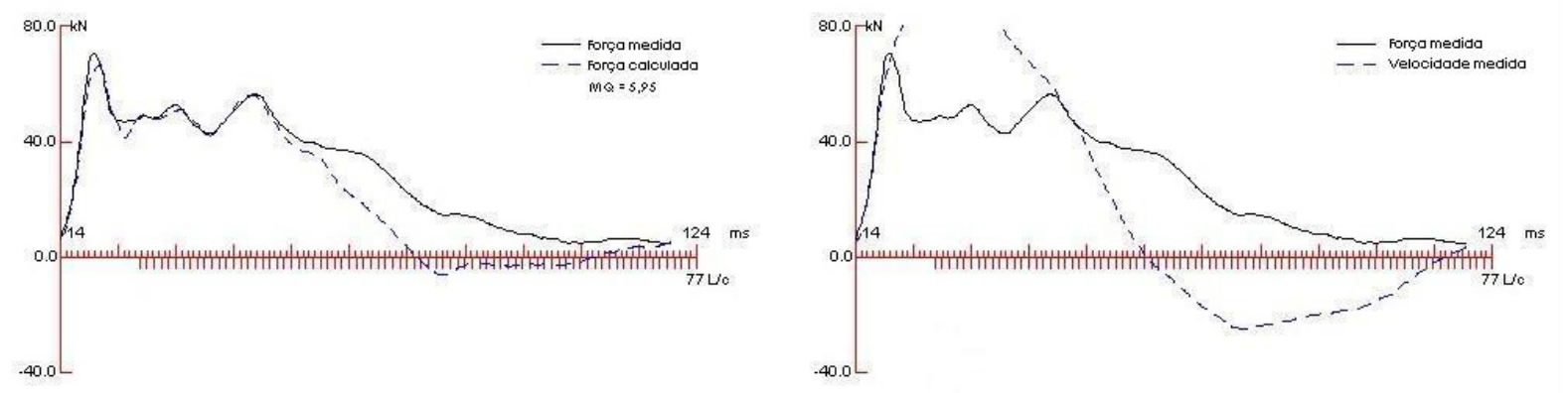

Figura B.53 - Curvas de força medida e calculada, e força e velocidade medidas, cava 8 , golpe 2
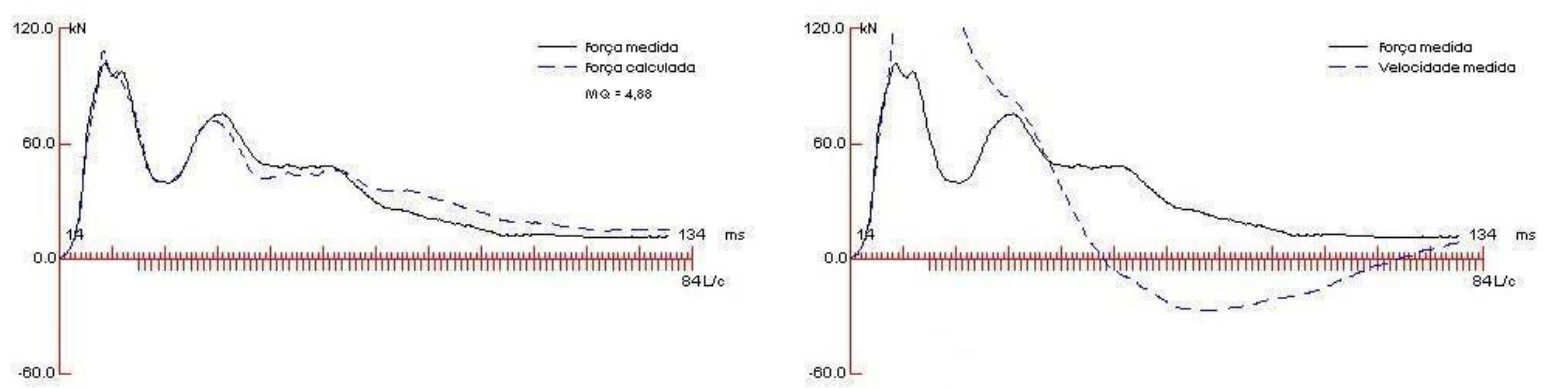

Figura B.54 - Curvas de força medida e calculada, e força e velocidade medidas, cava 8 , golpe 3 

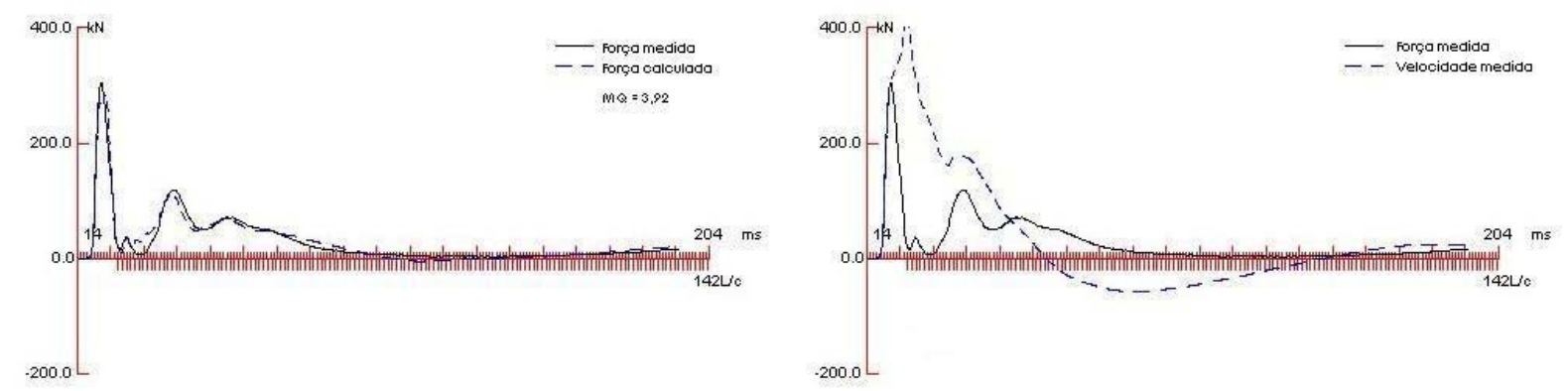

Figura B.55 - Curvas de força medida e calculada, e força e velocidade medidas, cava 8 , golpe 4
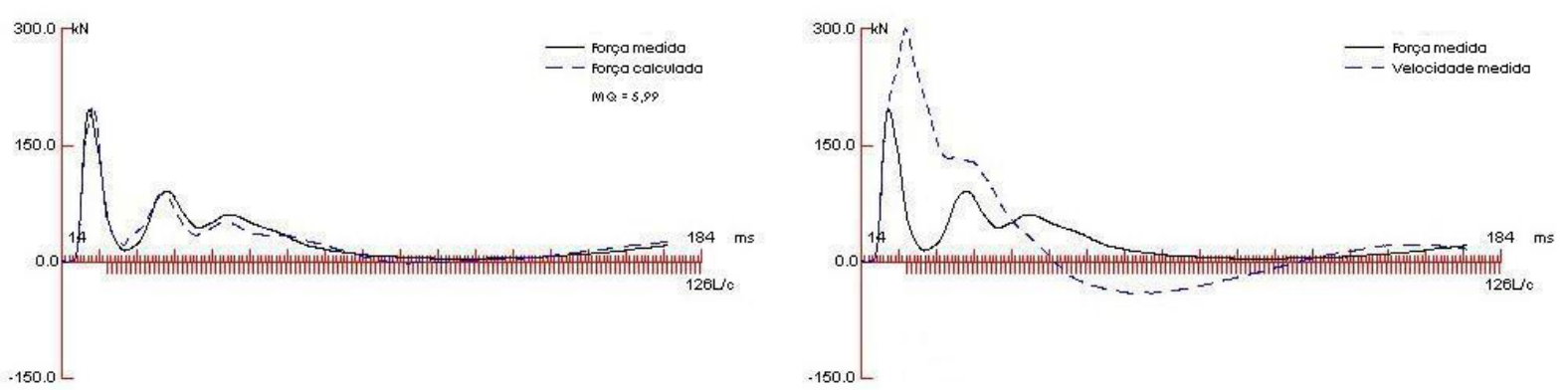

Figura B.56 - Curvas de força medida e calculada, e força e velocidade medidas, cava 8 , golpe 5
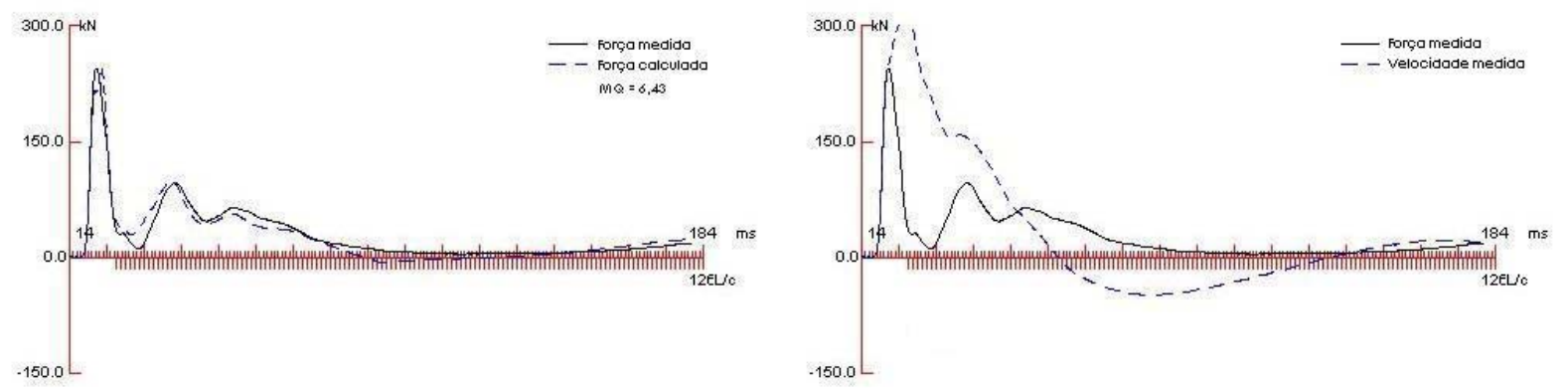

Figura B.57 - Curvas de força medida e calculada, e força e velocidade medidas, cava 8 , golpe 6 

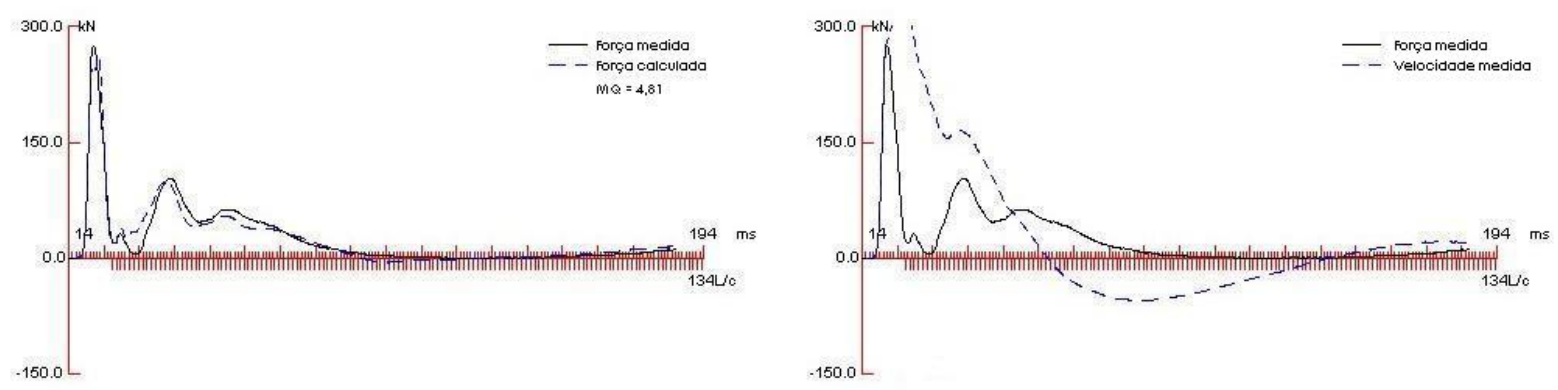

Figura B.58 - Curvas de força medida e calculada, e força e velocidade medidas, cava 8, golpe 7
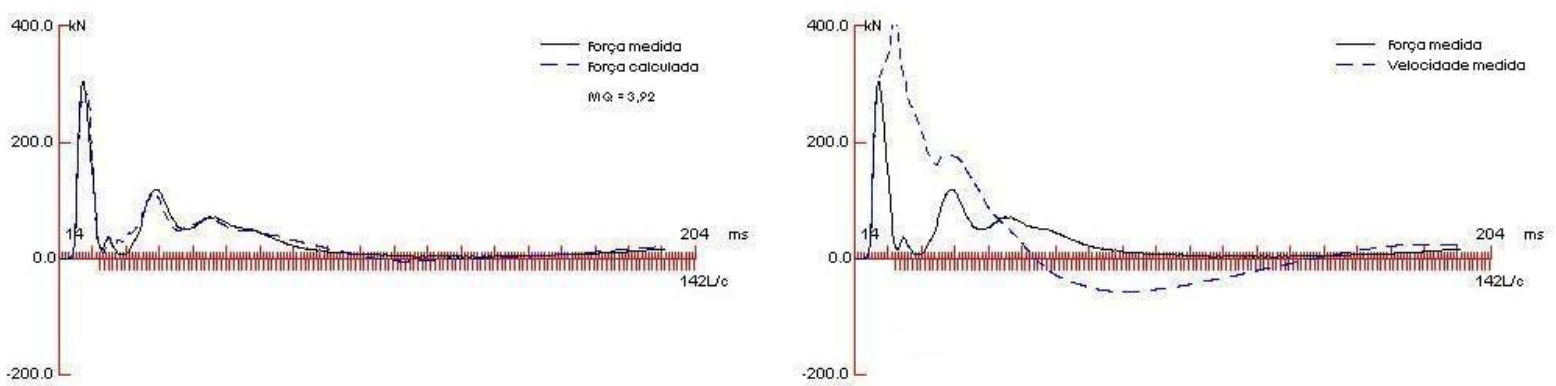

Figura B.59 - Curvas de força medida e calculada, e força e velocidade medidas, cava 8 , golpe 8
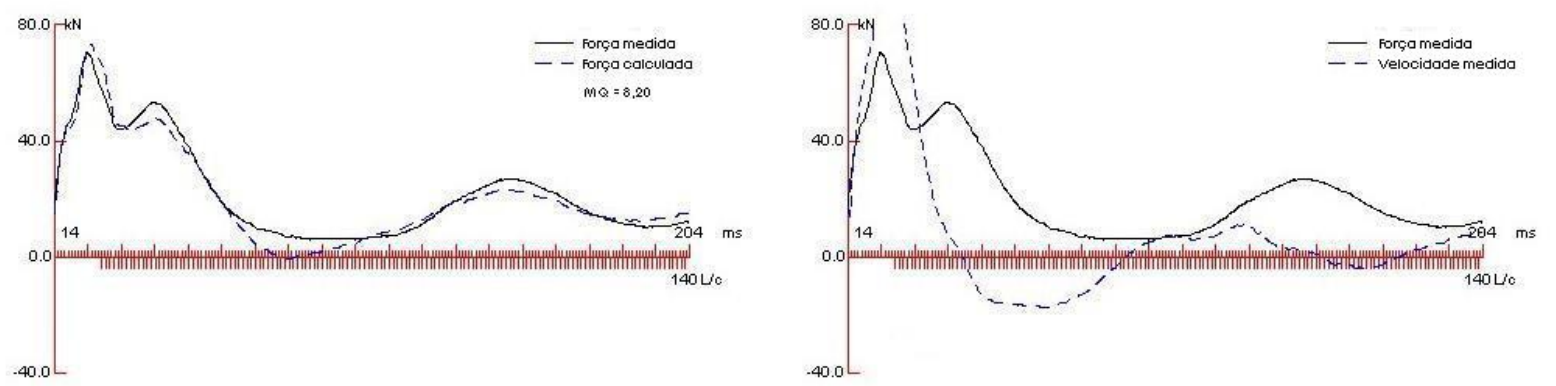

Figura B.60 - Curvas de força medida e calculada, e força e velocidade medidas, cava 9 , golpe 1 

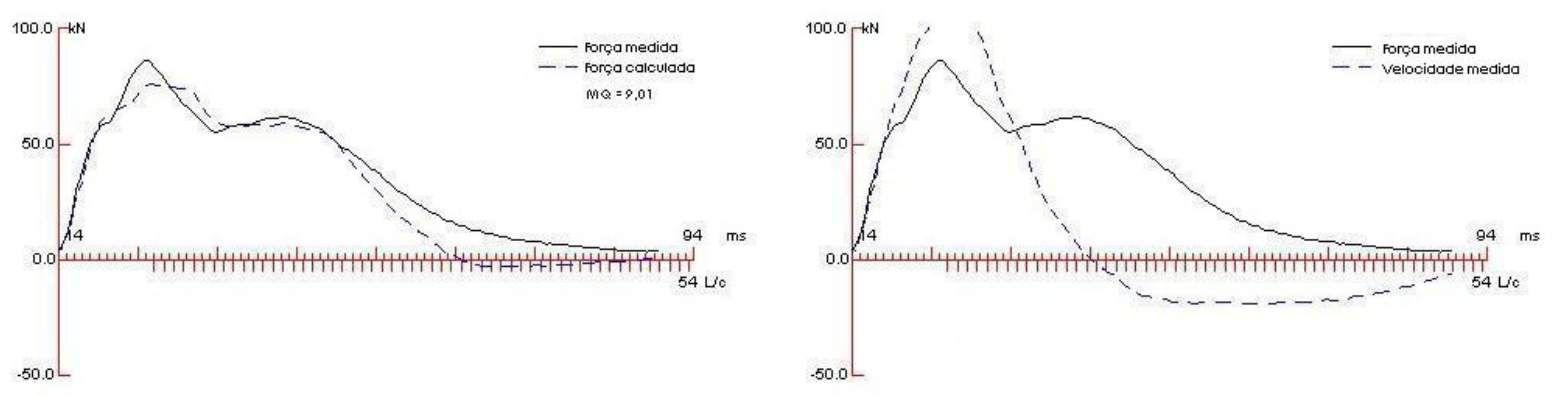

Figura B.61 - Curvas de força medida e calculada, e força e velocidade medidas, cava 9, golpe 2
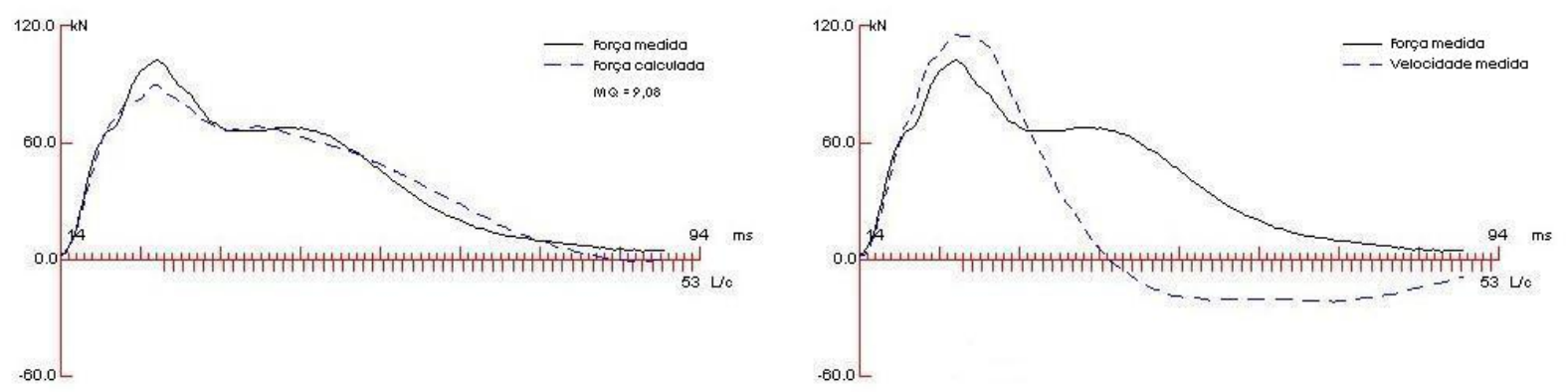

Figura B.62 - Curvas de força medida e calculada, e força e velocidade medidas, cava 9 , golpe 3
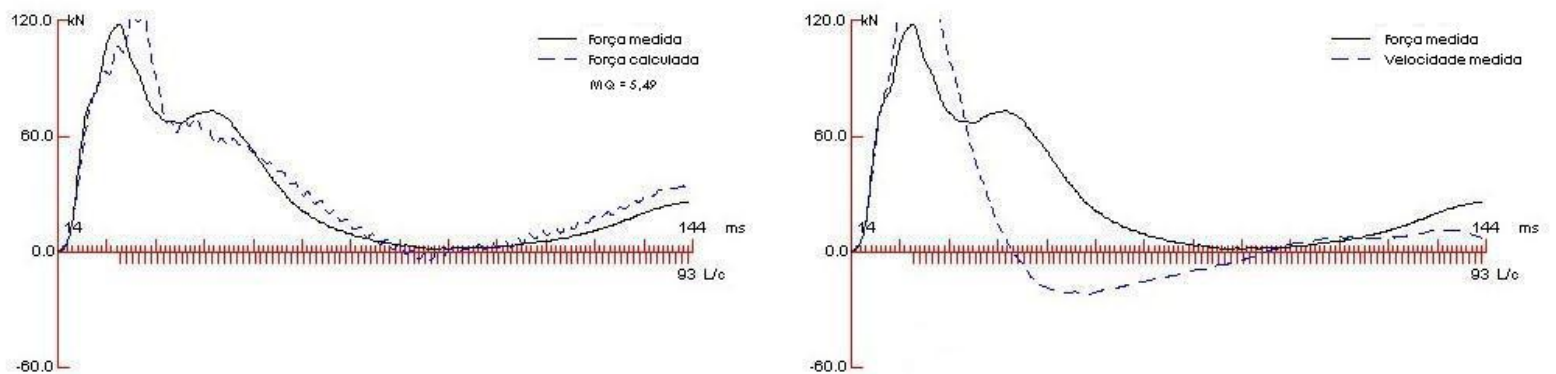

Figura B.63 - Curvas de força medida e calculada, e força e velocidade medidas, cava 9, golpe 4 

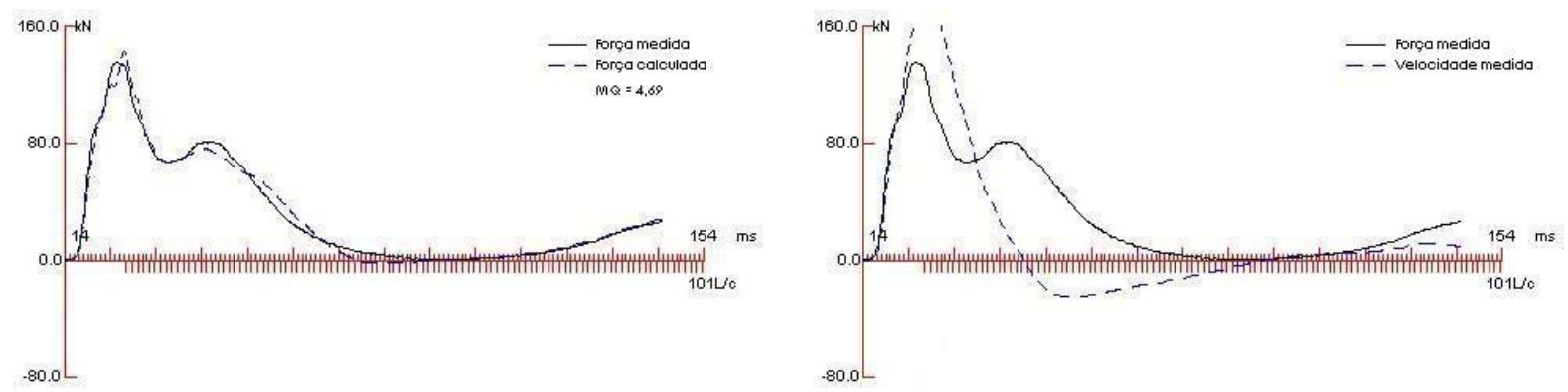

Figura B.64 - Curvas de força medida e calculada, e força e velocidade medidas, cava 9, golpe 5
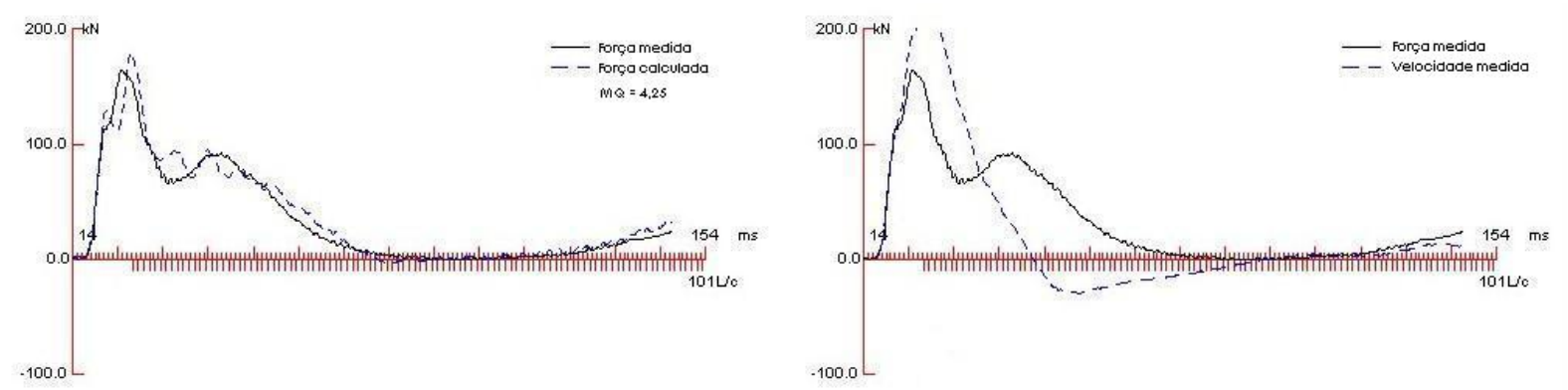

Figura B.65 - Curvas de força medida e calculada, e força e velocidade medidas, cava 9, golpe 6
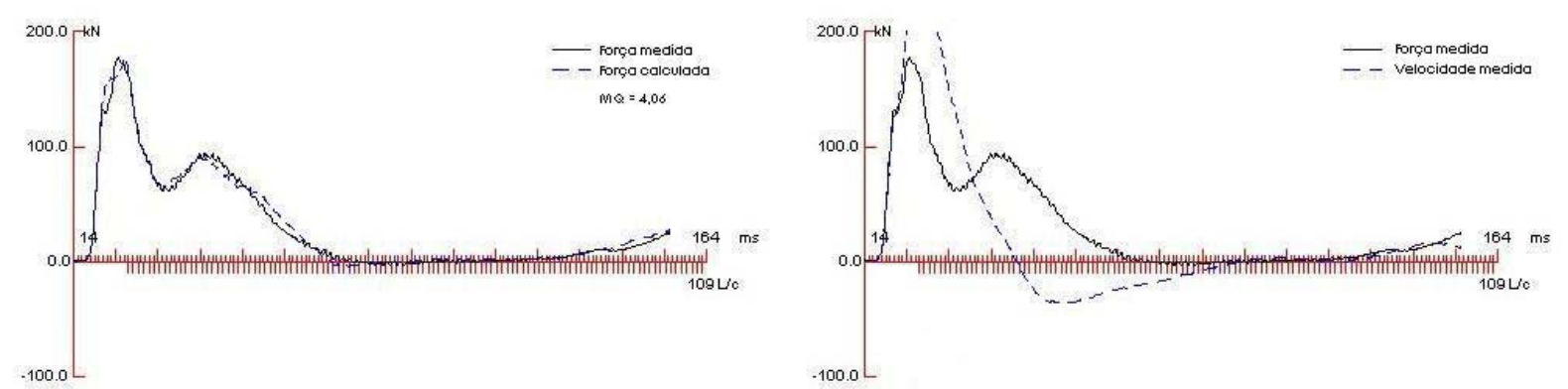

Figura B.66 - Curvas de força medida e calculada, e força e velocidade medidas, cava 9, golpe 7 

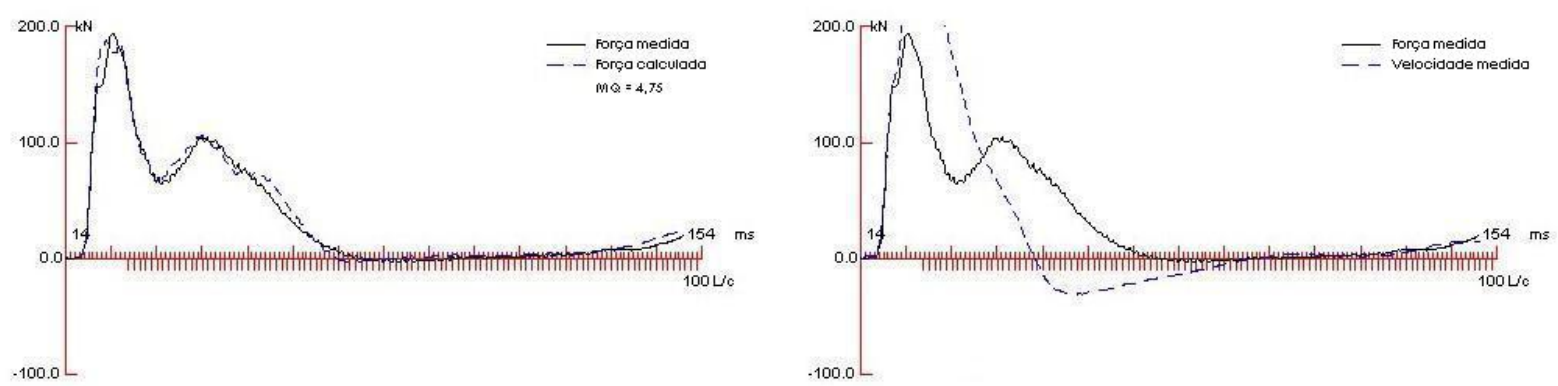

Figura B.67 - Curvas de força medida e calculada, e força e velocidade medidas, cava 9, golpe 8 